
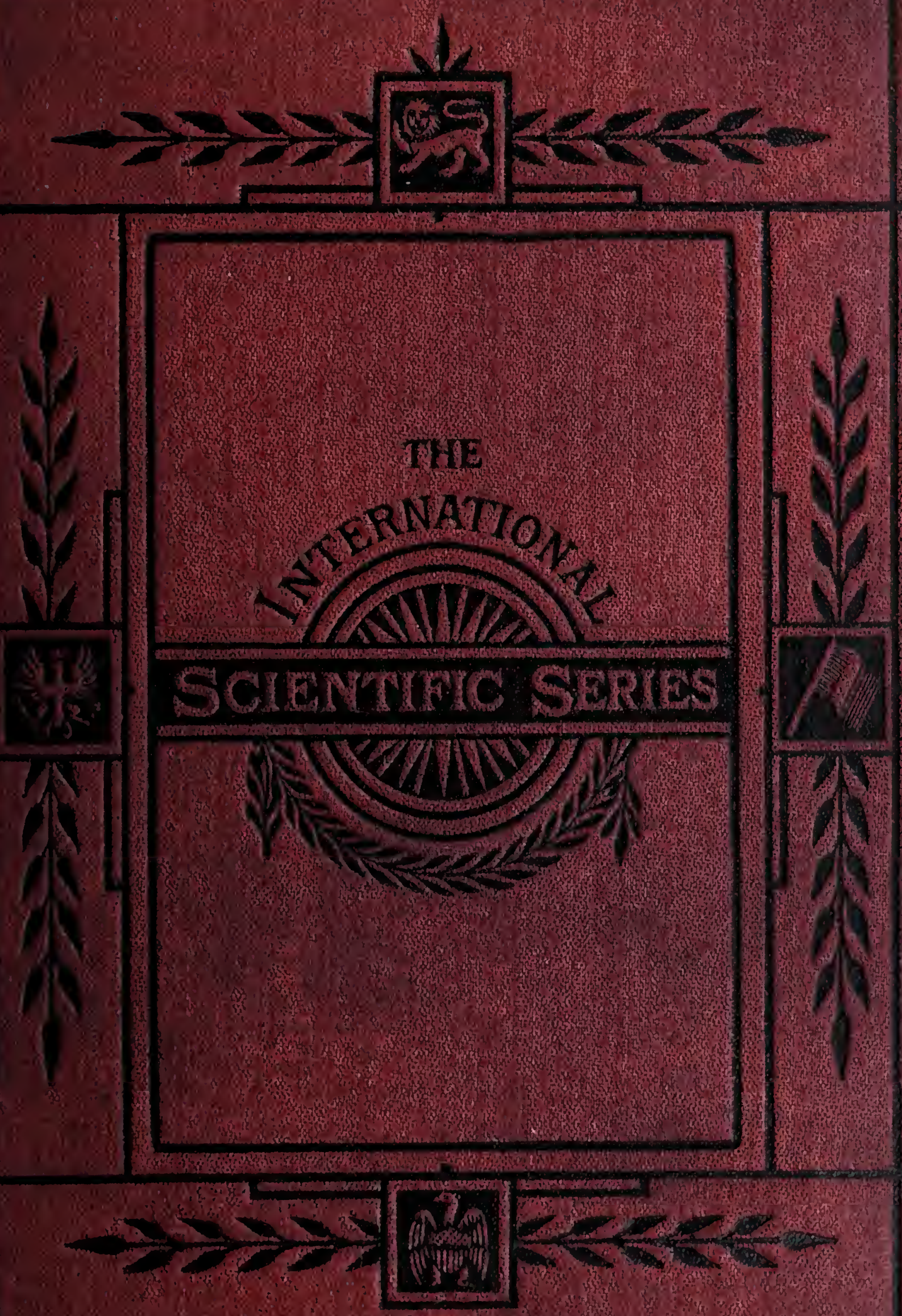


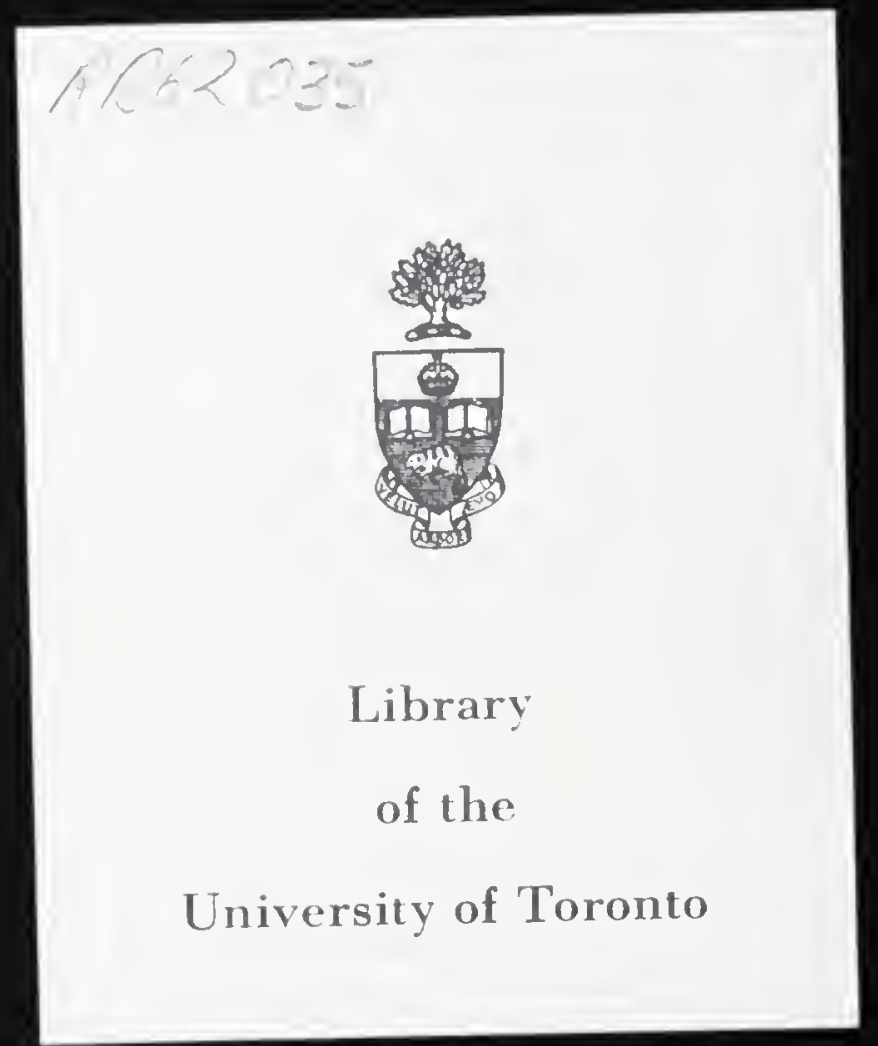


Digitized by the Internet Archive in 2018 with funding from University of Toronto 




\section{INTERNATIONAL SCIENTIFIC SERIES.}

Each Book Complete in One Volume. Crown 8vo. eloth, $5 s$. unless otherwise described.

I. FORMS of WATER: in Clouds and Rivers, Ice and Glaciers. By J. Tyxdalid, LL.D., F.R.S. With 25 Illustrations. Eleventh Edition.

II. PHYSICS and POLITICS; or, Thoughts on the Application of the Principles of 'Natural Selection' and 'Inheritance' to Politicil Society. By Walter Bagenot. Ninth Edition.

III. FOODs. By Enward Smith, M.D., LL.B., F.R.S. With 156 Illustrations. Tenth Edition.

IV. MIND and BODY: the Theories of their Relation. By Alexander Baix, LL.D. With Four Illustrations. Eighth Edition.

V. The Study of SOciology. By Herbert Spencer. Sixteenth Edition.

VI. The CONSERVATION of ENERGY. By Balfour Srewart, M.A., LL.D., F.R.S. With 14 Illustrations. Eighth Edition.

VII. ANIMAL LOCOMOTLON; or, Walking, Swimming, and Flying. By J. B. Petriarkw, M.D., F.R.S., \&c. With 130 Illustrations. Fourth Edition.

VIII. RESPONSIBILITY in MENTAL DISEASE. By HeNrY MaUdsLex, M.D. Fifth Edition.

IX. The NEW CHEMIsTRY. By Professor J. P. Сооке, of the Harvard Unlversity. With 31 Illustrations. Tenth Edition.

X. The SCIENCE of LAW. By Professor Sheldon Amos. Seventh Edition.

XI. ANIMAL MECHANISM : a Treatise on Terrestrial and Aërial Locomotion. By Professor E. J. MAkey. With 117 Illustrations. Third Edition.

XII. The DOCTRINE Of DESCENT and DARWINISM. BY Professor OSCAR SCHMIDT (Strasburg University). With 26 Illustrations. Eighth Edition.

XIII. The HISTORY of the CONFLICT between RELIGION and SCIENCE. BS J. W. Draprn, M.D., LL.D. Twenty-first Edition.

XIV. FUNGI: their Nature, Influences, Uses, \&c. By M. C. Conke, M.A., LL.D. Edited by the Rev. 3f. J. BrRkrLEx, M.A., F.I.S. With Illustrations. Fourth Elition.

XV. The CHEMISTRY of LIGHT and PHOTOGRAPHY. By Dr. Hermaxy Voger. With 100 Illustrations. Fifth Edition.

London: KEGAN PAUL, TRENCH, TRÜBNER, \& CO., LTH. 


\section{The Intemational Scientific Series-continued.}

XVI. The LIFE and GROWTH of LANGUAGE. By WiLlin DWıHT WhITXEY. Sixth Edition.

XVII. MONEY and the MECHANISM of EXCHANGE. By W. STANley Jevons, M.A., F.R.S. Ninth Edition.

XVIII. The NATURE of LIGHT, with a General Account of PHYSICAL OPTICS. By Dr. EUGke LoMmki. With 188 Illus. trations and a 'Table of Spectra in Chromo-lithography. Fiftl Edition.

XIX. ANIMAL PARASITES and MESSMATES. By Monsieur Vax Benenen. With 83 Illustrations. Fourth Edition.

XX. FERMENTATION. By Professor Schützennergar. With 28 Illustrations. Fourth Edition.

XXI. The FIVE SENSES of MAN. By Professor BrirnsteIn. With 91 Illustrations. Sixth Edition.

XXII. The THEORY of SOUND in its RELATION to MUSIC. By Professor Pietro Blaskilsa. With numerous Illustrations. Fifth Edition.

XXIII. STUDIES in SPECTRUM ANALYSIS. By J. NonMAN LOCKYER, F.R.S. With Six Photographic Illustrations of Spectra, and numerous Engravings on Wood. Fourth Edition. 6s. $6 d$.

XXIV. A HISTORY of the GROWTH of the STEAM ENGINE. By Professor R. H. Thums'oN. With numerous Illustrations. Fourth Edition.

XXV. EDUCATION as a SCIENCE. By Alexander Bain, LL.D. Eighth Edition.

XXVI. The HUMAN SPECIES. By Professor A. De Quatrufages, Nembre de l'Institut. Fifth Edition.

XXVII. MODERN CHROMATICS. With Application to Art and Industry. By OGDEN N. ROoD. Third Edition. With 130 original Illus. trations.

XXVIII. The CRAYFISH : an Introduction to the Study of Zoology. By T. H. HcxLKY, F.R.S. Fifth Edition. With 82 Illustrations.

XXIX. The BRAIN as an ORGAN of MIND. By H. Charlion BAstian, M.D. Fourth Edition. With 184 Illustrations.

XXX. The ATOMIC THEORY. By Professor A. Wurtz. Trans. lated by E. Claminshaw, F.C.S. Sixth Edition.

XXXI. The NATURAL CONDITIONS of EXISTENCE as they affect Animal Life. By KarL Skmper. Fourth Ldition. With 2 laps and 106 Woodeuts.

XXXIL. GENERAL PHYSIOLOGYO IMUSCLES and NERVES. By Prof. J. Rosenthal. Third Edition. With 75 lllustrations.

London: KEGAN PAUL, TRENCH, TRÜBNER, \& CO., LTD. 
XXXII. SIGHT: an Exposition of the Principles of Monocular and Binocular Vision. By Joskip Lx Coste, LL.D. Second Edition. With 132 Illustrations.

XXXIV. ILLUSIONS: a Psychological study. By Jamks Sully. Third Elition.

XXXV. VOLCANOES: what they are and what they teach. By JoHN W. JUDD, F.R.S. Fourth Editiou, With 96 Illustrations.

XXNI. SUICIDE: an Essay on Comparative Moral Statistics. By Professor H. Morseld.I. Second Ellition.

XXIVII. THE BRAIN AND ITS FUNCTIONS. By J.LuYs, Plyysician to the Hospice de la Salpetrière. With numerous Illustrations. Third Edition.

XXXVII. MYTH AND SCIENCE: an Essay. By Tito Vignol. Third Edition.

XXXIX. THE SUN. By C. A. Young, Ph.D., LL.D. Fourth Edition. With numerous Illustrations.

XL. ANTS, BEES, and WASPS. A Record of Observations on the Habits of the Social Hymenoptera. By Sir JoHN LUBвосK, Bart., M.P. 'Tenth Edition. With õ Chromo-lithographic Plates.

XLI. ANIMAL INTELLIGENCE. By Grorge J. Ronanks, LL.D., F.R.S. Fifth Editiou.

XLII. The CONCEPTS and THEORIES of MODERN PHYSICS. By J. B. Stallo. Third Edition.

XLIII. DISEASES of MEMORY. An Essay in the Positive Psychology. By Th. Ribot. Third Edition.

MLIV. MAN BEFORE METALS. By N. Joly, Correspondent de l'Institut de France. Fifth Edition. With 148 Inustrations.

XIV. THE SCIENCE of POLITICS. By Prof. SHeidon A.sos. Third Enlition.

KLVI. ELEMENTARY METEOROLOGY. By Robret H. ScoTr. Fifth Elition.

ILVII. THE ORGANS of SPEECH. Hy Geurg Herman vos" Mrékr. With 47 Inustrations.

ILVII. FALLACIES : i View of Logic from the Practical Side. By AlFREl SIDGWICK. Second Edition.

SLIX. THE ORIGIN OF CULTIVATED PLANTS. By Alphosise De Ca.MOLLr. Second Edition.

L. JELLY FISH, STAR FISH, AND SEA URCHINS. Being a Research on Primitive Nervulus Systema. By G. J. Romaxks, LL.D., F.R.S. Second Ldition.

II. THE COMMON SENSE OF THE EXACT

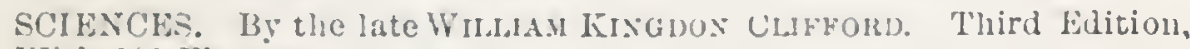
With 100 Figures.

Londun: KEGAN PAUL, TRENCH, TRLBNER, \& CO., LTD. 
The International Scientific Series-continued.

LII. PHYSICAL EXPRESSION : its Modes and Principles. By Frascrs Wakser, II.D., F.R.C.P. Seeond Edition. With 50 lllustrations.

LIII. ANTHROPOID APES. By RoBerT HARTMAN. With 63 Illustrations. Seeond Eilition.

LIV. THE MAMMALIA IN THEIR RELATION TO PRIMEVAL TIMES. By OScar Schmint. With 51 Woodents.

LV. COMParative LITERAture. By II. Macauiay POSNEIT, LL.D.

LVI. EARTHQUAKES and other EARTH MOVEMENTS. By Prof.JoHN MILx. With 38 Figures. Third Edition.

LVII. MICROBES, FERMENTS, and MOULDS. By E. I. Trovessar'T. With 107 lllustrations. Seeond Edition.

LVIII. GEOGRAPHICAL and GEOLOGICAL DISTRIBU. TION of ANIMALS. By Prof. A. HemLin.

LIX. WEATHER: a Popular Exposition of the Nature of Weather Clianges from Day to Day. By the Hon. RAlpH ABEronomby. With 96 Figures. Third Edition.

Lx. ANimaL Magnetism. By Alered Binet and Ciraries FÉre. Third Edition.

LXI. MANUAL OF BRITISH DISCOMYCETES, with descriptions of all the Species of Fungi hitherto found in Britain ineluderl in the Family, and Illustrations of the Genera. By WildiAM PHILlus, F.L.S.

LXII. INTERNATIONAL LAW. With Materials for a Code of Interuational Law. By Professor Leovi Levi.

LXIII. The GEOLOGICAL HISTORY of PLANTS. By Sir J. William Dawsox. With 80 Illustrations.

I.XIV. THE ORIGIN OF FLORAL STRUCTURES THROUGH INSECT AND OTHER AGENCIES. By Prof. G. HExSLOW.

LXV. On the SENSES, INSTINCTS, and INTELLIGENCE of ANIMALS, with special reference to INSECTS. By Sir Jon.: LUBrock, Bart., II.P. With 118 Illustrations. Third Edition.

LXVI. THE PRIMITIVE FAMILY IN ITS ORIGIN $\triangle N D$ DEVELOPMENT. By C. N. STARCKE.

LXVII. PHYSIOLOGY Of BODILY EXERCISE. By FrRNAND LAgRAage, M.D. Seeond Edition.

LXVIII. The COLOURS of ANIMALS: their Meaning and Use, espeeially eonsilered in the ease of Insects. By E. B. PoUlios, F.R.S. With Chromolithographie Frontispiee and upwards of 60 Figures in Text. Seeond Edition.

LXIX. INTRODUCTION TO FRESH-WATER ALGA. With an Enumeration of all the British Speeies. By M. O. CoOkE, LL.D. With 13 Plates Illustrating all the Genera.

IAX. SOCIALISM: NEW AND OLD. By William Graham, II.A.. Professor of Political Economy and Jurisprudenee, Queen's College, Beliast. Seeond Edition.

LXXI. COLOUR-BLINDNESS AND COLOUR-PERCEPTION. By F. W. EDmugr-Grees, M.D. With 3 Coloured Plates.

IXXII. MAN AND THE GIACIAL PERIOD. By G. F. WIIGIIT, D.D. With 111 Illustrations and Maps.

LXXII. HANDBOOK OF GREEK AND LATIN PALAFOrraphy. By E. MAdude Thompson. With Tables of Aiphabets and Faesimiles.

London: KEGAN PAUL, TRENCH, TRÜBNER, \& CO, LTD. 


\section{INTERNATIONAL SCIENTIFIC SERIES VOL. LXXV.}



THE

\title{
DISPERSAL OF SHELLS
}

\author{
AN INQUIRY INTO THE MEANS OF \\ DISPERSAL POSSESSED BY FRESH.WATER \\ AND LAND MOLLUSCA
}

\begin{abstract}
- BY
HARRY WALLIS KEW, F.Z.S.

WITH $\triangle$ PREFACE BY

ALFRED RUSSEL WALLACE, LL.D., F.R.S.. ETC.
\end{abstract}

HTH ILLUSTRATIONS.

\section{LONDON}

KEGAN PAUL, TRENCH, TRÜBNER \& CO., LTU. PATERNOSTER HOUSE, CHARING CROSS ROAD 



\section{PREFACE.}

HARDLY any branch of natural history has been so neglected as that which treats of the various modes by which the different classes of organisms have become dispersed over the surface of the globe. Scattered observations have indeed been made by many writers, but Lyell and Darwin were the first to gather together the existing evidence on the subject, or to test by actual experiment the effects of exposure to salt water on the vitality of seeds and land-shells. Owing to this neglect the idea has arisen that seas of very moderate width serve as complete barriers to the dispersal of most living things; and it has been thought necessary to postulate great and often repeated geographical mutations, and even to bridge across the widest and decpest occans, in order to account for the actual distribution of mammals or reptiles, of plants, insects, or terrestrial mollusca.

It was Darwin who first taught us that these assumptions of vast and repeated changes in the distribution of sea and land were at once inadmissible and unnecessary. By his original and masterly investigation 
into the phenomena presented by oceanic islands he showed that these islands had never been connected with the continents, as had been almost invariably assumed by previous writers, and, consequently, that their entire fauna and flora must have originated from such species as could, in the course of ages, have reached the islands by natural means of dispersal. Hence the importance of studying what are the means of dispersal of the various groups, and why it is that, with the two absolute exceptions of mammals and amphibia, none of the larger groups of animals or plants are invariably absent from this class of islands. As a corollary from his investigation he was led to conclude that the great oceans were, broadly speaking, permanent features of the earth's surface, and that it was scientifically inadmissible to bridge them over in various directions and at various geological epochs in order to provide a short and easy road for the passage of bectles or snakes, snails or frogs, and thus save us the trouble of solving the problem of their a ctual distribution by less obvious and also by less heroic means.

Having myself devoted some time and research with the object of showing that almost every anomaly in the distribution of animals and plants may be explained by a careful consideration of the various means of dispersal which organisms possess, combined with the climatic and geographical changes which are known to have occurred during later geological times, and taking into account the known distribution of the several groups at remote epochs as proved by the discovery of 
fossils in regions far removed from the lands now inhabited by their living representatives, I am especially interested in Mr. Kew's attempt to bring together all that is known of the means of dispersal of one of the groups as to which such information was most needed. He has devoted to the task much labour and research, and has brought together a mass of information of great value. Many of the facts he adduces are so curious and interesting that they will attract the attention of many classes of readers and thus lead, it is to be hoped, to the accumulation of facts which are still required to complete our knowledge of this important subject.

I heartily congratulate the author on his choice of so useful and interesting an inquiry for his first work, and on the systematic and accurate manner in which he has marshalled the facts he has collected. Many books of far greater pretension, even though they should contain descriptions of scores of new species and work out their internal structure with the greatest accuracy, may yet be of less interest to the philosophical naturalist than this unpretending little volume. In its pages we are afforded a glimpse of what seem at first sight to be but trifles and accidents in nature's workshop, but which are really the tools with which she produces some of her most striking results. It is owing to such trifling occurrences as the occasional attachment of a living shell to a beetle's leg, or the conveyance of seeds in the mud adhering to a bird's foot, that many remote islands have become stocked with life, and the range of species 
extended or modified over the earth; while through changes of the organic environment thus effected even the origination or the extinction of species may have been brought about. 


\section{INTRODUCTORY NOTE.}

THE distribution of fresh-water and land shells has been looked upon as presenting special difficulties on the theory of single birth-places or "centres of creation." Mr. Darwin, in characteristic letters, in I $856-7$, spoke of being driven mad by land molluscs, and fresh-water kinds, he said, had been a horrid incubus." In the "Origin of Species," however, he was able to suggest several possible means of dispersal both for terrestrial and aquatic groups, and speaking of the latter he remarked that many facts throwing light on the subject would doubtless be discovered." Quite a number of facts of the kind indicated have been recorded since the publication of the "Origin," and a collection of these together with some hitherto unpublished items-both as regards fresh-water and land shells-is now given. In compiling this, and the essays on subsidiary subjects also given, the writer has received constant help in the way of notes, references, \&c., from a number of friends and correspondents whose courteous co-operation is

"Life and Letters," vol. ii. pp. 85,93 .
3 "Origin," I 859, p. 385 , and see ed. 6, pp. $344,353$. 
gratefully acknowledged; to Mr. Robert Standen and Mr. J. Ray Hardy he is under obligation for many striking facts and the loan of specimens, to Mr. G. K. Gude and Mr. R. W. Goulding for the preparation of several translations, and to Mr. C. T. Musson for permission to use a manuscript work on the "Land and Fresh-water Shells of Nottinghamshire," containing excellent essays on local distribution and means of dispersal.

To Dr. Alfred Russel Wallace, who, with great kindness, has looked over the proofs and contributed the foregoing preface, the writer owcs a special and irredeemable debt of gratitude.

With a view to the collection of further facts illustrating the means of dispersal possessed by molluscs and allied animals, Dr. Wallace has suggested that the writer should invite "naturalists and sportsmen in all parts of the world" to co-operate by furnishing notes of, or references to, observations which they may have made or recorded, or which they may be able to make or record in the future. Many persons, both at home and abroad, he imagines, would make observations "if they knew what was wanted, and had the address of some one who would appreciate and use them." It may be mentioned that, amongst other things, the examination of large numbers of floating trees, etc., encountered upon the occan, and of drift-timber and brushwood found stranded upon the coast-line, would possibly be productive of surprising results, as also would the careful and systematic inspection of the feet and feathers of birds shot 
on the wing. It is desirable, moreover, that search should be made for living mollusca in the crops of birds and in the stomachs of other shell-eating creatures.

It need hardly be added that communications with which the writer may be favoured will be welcomed at the under-mentioned address, and carefully acknowledged.

H. W. K.

5, Giesbach Road, Upper Holloway, London.

Scpientier, IS93.

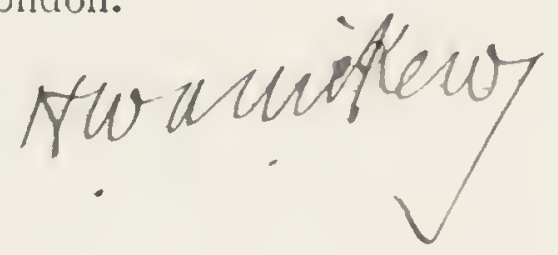





\section{CONTENTS.}

CHAPTER I.

Fresh-Water Shells-Anomalies in Local Distribu-

PAGE TION

CHAPTER II.

MEANS OF DISPERSAL

CHAPTER III.

Transplantation of Bivalves 56

CHAPTER IV.

Transplantation OF UNivalves . • . . $\quad 85$

CHAPTER V.

Land Shells: their Tenacity of Life • . . 90

CHAPTER VI.

MEANS OF DISPERSAL • • • • • • • • 115

CHAPTER VII.

Dispersal of Slugs • • • • • . . . 167 


\section{CHAPTER VIII.}

DisPERSAL OF FRESH-IVATER AND LAND MOLLUSCA by

P'AGE $\operatorname{MAN}$. . . . . . . . I7S

CHAPTER IX.

ON the Fresh-iwater and Land Mollusca in'troduCed into the British Isles by Human Agency 209

$\operatorname{INDEX} \quad . \quad . \quad . \quad . \quad . \quad . \quad 265$ 


\section{THE DISPERSAL OF SHELLS.}

\section{CHAPTER I.}

FRESH-IVATER SHELLS-ANOMALIES IN LOCAL

DISTRIBUTION.

MOST naturalists of recent years have agreed that "the several species of the same genus, though now inhabiting the most distant quarters of the world, must originally have proceeded from the same source, as they are descended from the same progenitor," and also, of course, that "the individuals of the same species, though now inhabiting distant and isolated regions, must have proceeded from one spot, where their parents were first produced," "and the acceptance of this view, now that it is very generally admitted that the great oceans-the most formidable of all barriers limiting the migrations of non-marine animals-have occupied the same general positions as they do now throughout all known geological periods, ${ }^{2}$ has naturally lent much interest and import-

1 Darwin, "Origin," ed. 6, 1890, pp. 319-20.

"Wallace, "Island Life," I88o, p. I44 ; ed. 2, I892, pp. I49-50; Darwin, "Origin," p. 288. For a summary of the evidence on this head, see "Island Life," pp. Ior-2; ed. 2, pp. 103-5. 
arce to the investigation and study of means of dispersal. Obviously, we are not now authorized in explaining all the difficulties which geosraphical distribution presents by suggesting multiple centres of creation or former radical changes in the relative positions of land and sea.

The wide ranges and singular distributions now enjoyed by many organisms seem, in these circumstances, well-nigh inexplicable; the ranges of some genera, as everyone is aware, are almost world-wide, some species extend over immense areas, and, moreover, there are cases in which the same or closely-allied forms occur at isolated points in remote parts of the world. Highly effectual means of dispersal of some kind or other must certainly have been in operation, for it is clear that the distribution, at lcast of many groups, cannot have resulted from gradual migration by ordinary modes of progression, and this is the more apparent, of course, with pre-eminently slow-moving inland animals like fresh-water and land mollusca. To such creatures evidently, as far as voluntary migration is concerned, even small arms of the sea, arid deserts, and elevated mountain-chains must be almost, or, perhaps, absolutely, impassable; but it has been remarked that such obstacles are not likely to have endured so long as the oceans.' It will not be forgotten, of course, that the great changes of level known to have taken place "within the period of existing organisms" certainly remove many difficulties, and it should be borne in 
mind, more especially in connection with discontinuous ranges, that many types are of immense antiquity, having survived numerous changes of climate and great oscillations of level, so that the distant regions in which they are now found may, in some cases, have formed parts of former continuous and very wide ranges. It ought also to be remarked, perhaps, that some eminent biologists, as, for instance, Professor Semper, think it possible that similar faunas in distant parts of the world may sometimes have been brought about by the convergence of formerly distinct types, ${ }^{1}$ and this, of course, cuts the Gordian knot much in the same way as did a formerly prevalent belief in multiple centres of special creation. Fresh-water forms are said to have been derived originally from the sea, and even now certain marine animals in all probability are gradually adapting themselves to fresh water, a process which may have been going on all through the ages, but I do not see that this much affects our present inquiry; it should certainly be taken into account, however, whenever the occurrence at distant places of allied fresh-water forms having near relatives in the sea is considered.

Fresh-water shells, it secms, if left to their own endeavours, would generally find great difficulty in extending their range beyond the limits of their own river-basin, for the dry land obviously presents. a formidable barrier to these animals, and, as Mr. Darwin remarks, each river-system with all the pools and lakes

'Semper, "Animal Life," Eng. transl., ed. 4, ligo, pp. 294 and 461. 
in connection with it seems completely cut off from every other river-system of the same country, and still more complete, of course, is the separation between the fresh-waters of distinct islands and continents. ${ }^{1}$ Some of the univalves live much out of water, but, even with these, powers of voluntary migration over land must be very limited. I find, however, in Mr. Musson's manuscript, a statement that a pond-snail (Limneea truncatula) has been seen travelling across dry fields. Bivalves seem practically incapable of migrating voluntarily beyond the limits of their own element and its immediate surroundings; some kinds, as is well known, are occasionally encountered in a living state, buried in sand, or amongst moss, \&c, at distances from water," but it is unlikely that they intentionally proceed to such spots. ${ }^{3}$ Notwithstanding these disabilities, however, we find a wide distribution characterizing many of the creatures, both univalves and bivalves, together also with most other freshwater productions. Some species range very widely, and, as Mr. Darwin observes,

1 Darwin, "Nature," xviii. (I878), p. I 20 , and see "Origin," p. 343 .

"See, for instance, W. Thompson, "Ann. and Mag. Nat. Hist.," vi. (I 84 I), p. I95; J. G. Jeffreys, "British Conchology," i. (I862), p. I7 ; L. Reeve, "Land and Fresh-water Mollusks," I863, p. 236 ; G. Roberts, "Zoologist," (3), ix. (1885), p. 47 I ; J. G. Milne, "Journ. of Conch.," vi. (I89r), pp. 4I3-I4, 4I8 ; C. T. Simpson, "Nautilus," v. (I891), p. I6.

3 One of the pea-shells (Pisidium pusillum), it is true, is said to have been seen creeping in damp moss 6-20 paces from water; D. Weinland, quoted in "Zoological Record," xiii. (1876), Moll. p. 57. 
allied forms, which "must have proceeded from a single source," prevail throughout the world. ${ }^{1}$

Much has to be explained, also, even in local distribution. Every naturalist remembers having seen shells in puddles formed after periods of excessive rain, in pools in quarries and pits, in drinking-troughs and water-butts, in tanks on the roofs of buildings, in newlyformed reservoirs and artificial lakes, in ponds on open pastures far away from the nearest streams, \&c. As the Rev. James Dalton long ago remarked, the creatures seem to possess a "mysterious faculty" of finding their way to the most unlikely habitations." Dispersal by some means must be constantly going on.

That almost every isolated cattle-pond which a farmer digs perhaps near the middle of an upland pasture should come to possess a molluscan fauna within a few years of its formation, though a matter of common observation, is certainly a surprising fact, and it is remarkable that writers of local lists when recording the existence of shells in such places have so generally passed over the circumstance without comnent. If multiple birthplaces were possible it is evident, of course, that the spreading of forms from their several centres would have to be explained, for no believer in multiple centres, I imagine, would go so far as to suppose that cattle-ponds are

1 "Origin," p. 344 ; but sce Semper, "Animal Life," p. 298.

"J. Dalton, "Zoologist," xix. (1861), 7318-9. Early in 1890 Mr. W. H. Heathcote saw a specimen of Limnaa truncatula crawling on the top of the tower of St. James' Church, Preston, ninety feet or more from the ground ! 
stocked by special acts of creation; curiously cnough, when a boy, I believe before reading any bosks, I was much puzzled at sceing some living thing in a newlyformed pool, and remember concluding that it must have been created there! Mr. Clement Reid, who has attended to this subject, has been in the habit of noting from time to time the species occurring in artificial ponds and other isolated waters; by so doing, as he puts it, "one can see the accumulated results of many years' dispersal, and can get some idca as to the extent to which it must be going on." As a rulc, he tells me, such waters only contain Limneee (generally L. peregra), but the species auricularia, truncatula, stagnalis, and palustris also occur, associated, sometimes, with the smaller Planorbes (generally spirorbis and vortex), and Physa fontinalis. The presence of bivalves, he adds, "is quitc cxceptional; the smaller Pisidia, especially $P$. pusillum, occasionally occur, and I have once found Spherm corneum, but never Unio or Anodon;" operculate pond-snails are almost invariably absent. More recentiy, this obscrver has published an able paper on the "Natural History of Isolated Ponds," based, for the most part, upon observations made on the South Downs. ${ }^{1} \quad$ These undulating chalk hills, it is stated, constitute a pre-eminently dry district in which, in order to provide water for the cattlc, ponds have to be dug at comparatively short distances from each other. When rendered impervious by puddling with clay or chalk-

${ }^{1}$ Clement Reid, Trans. Norfolk and Norwich Nat. Soc., v. (I 892$), 272$. 
mud, or sometimes by a lining of concrete, such "dewponds" retain a store of water, except during droughts of exceptional duration, derived from "the rain, dew, and condensation of the mists which often hang on the tops of the hills." Many occur at the distance of a mile or even two or three miles from the nearest stream or marsh, and, as the Downs rise to Soo fect, their average height is fully 200 fect above other water, so that the aquatic animals and plants found therein must certainly have been "transported uphill as we!l as across uncongenial tracts of dry grass," or be descended from ancestors thus transported. Notwithstanding this extreme isolation, however, the ponds are often found to be inhabited by fresh-water shells. Two, at least, of the three examples given by Mr. Reid were thus inhabited:

(I.) "Large dew-pond on the open Down nearly a milc cast-south-cast of Amberley Station; height, 3 Io feet above the sea, and 300 feet above the marshes of the Arun; nearest water, the marshes of the Arun, distant half a mile. Noted I $5^{\text {th }}$ November, I $8 S_{4}$. This pond has evidently becn made several ycars, and is now full of water-plants. The species observed, were Juncus (not in flower or fruit, though very abundant), Potamogeton densus (very common), Ramunculus aquatilis, Chara, and a single small, but vigorous tuft of Elodea canadensis. . . (I have apparently omitted to note the mollusca from this pond, if there were any).

(2). "Redlion Pond, on the open Down, three miles south-east of Lewes; height 540 fect above the sca, and 530 fect above the marshes of the Ouse; nearest water, 
the marshes of the Ouse, distant seven furlongs. Noted June, I 890 . The species observed were Limnea peregra, Ranunculus aquatilis, and Elodea.

(3). "Small pond by the side of the high road, half a mile west of Clirist Church, Stansted (near the Hampshire border); height, 3 I 2 feet above the sea, and 220 feet above the nearest stream; nearest water a small stream, distant about two miles to the south-south-west, but apparently containing neither of the plants found in the pond. Noted September 25th, I89I. The species found were Limncea peregra, Planorbis spirorbis, Potamogeton natans, Zannichellia palustris, all abundant; the two plants in fruit, and carrying many eggs of Limnce. Zannichellia occurs again in a pond in a brick-field, two miles to the south-west, but does not fruit there; the nearest natural station for it seems to be in the slightly brackish marshes near Emsworth, four miles to the south. Potamogeton natans can probably be found within three miles. This pond is overshadowed by a large oak, and supplied by dew and rain off the road; neither of the plants, however, is a species likely to be brought to the locality by carts or on the hoofs of horses."

The absence of bivalves from such ponds, it is true, need hardly be regarded as surprising, but I am unable to agree with Mr. Reid in thinking that the occurrence of the smaller kinds in isolated waters is likely to bc altogether exceptional. The creatures may easily be overlooked, and Mr. Reid tells us, in the paper just quoted, that he "could only stay to note the common and conspicuous animals and plants." The catch-water 
or dew-ponds of the Lincolnshire Wolds, dug out of the chalk and puddled with clay, though often or usually dry in summer, do not essentially differ, I imagine, from those of the Downs. Recently my brother showed me a pond of this kind, the most isolated he could find about Louth, situate on one of the highest of the rolling chalk hills in the neighbourhood, at a great distance from any other water, and in this were bivalves of two kinds, Spharium lacustre and Pisidium pusillum, the former in good numbers. In ponds on lower ground and less remote from other water (but perfectly isolated and out of the reach of floods), where the conditions of existence are probably more congenial, small bivalves certainly seem to occur with some frequency. Uncongenial conditions, Mr. Reid remarks, have probably much to do with the poverty of the fauna and flora in dew-ponds. Mr. Musson, who, also, has paid some attention to the subject, speaks of Spharium lacustre as a species commonly found in "upland ponds" [ponds without inlet or outlet, dependent directly on rain-water for their supply, as distinguished from such as are affected by floods and rivers], in which also, as he adds, Sphorium corneum, more generally found in rivers, canals, \&rc., occurs occasionally. A small "upland" horse-pond, near the Hemlock Stone, near Nottingham, examined by him during I 883 and I 894 , was inhabited by six kinds of molluscs, of which three were bivalves: Sphcerium lacustre and two species of Pisidium; and three univalves: Planorbis nitidus, $P l$. nautileus, and Ancylus lacustris - a strange set of species, as he remarks, 
to have come together in one small pond. I will here add particulars of the Lincolnshire catch-water pond referred to, and of one or two other isolated ponds, \&c. Details, in such cases, must always be tedious, but the subject, as it seems to me, is an interesting one.

Pond at Welton-le-Wold, Lincolnshirc.-A small pond, about nine yards in length, on the Wolds not far from Louth, near the crown of Bunker's Hill. A great distance from any other water, and far above the nearest stream. Between arable fields, but with no ditches near. Probably old, having cxisted, perhaps when the wold was unenclosed; remains of a rough pump are to be seen on one of the banks. Water derived solely from rain, \&c., falling in the immediate neighbourhood. No water-weeds are likely to have been planted by man. Four species of shells occur: Spharium lacustre, Pisidium pusillum, Limmaa porgora, and Limuace truncatula.

Pond at Riplingham, Yorkshire-Mr. F. W. Fierke, of Hull, has favoured me with particulars of a somewhat similar pond on the Yorkshire Wolds, at Riplingham, scooped out of the chalk and laid over with clay, and supplied with water by rain and surface drainage only. The ever present Limncea peregra, among higher organisms seemingly the only inhabitant, exists in countless numbers, almost covering the bottom. There are no water-weeds. Many ponds of this kind,

1 Specimens were exhibited at the Conchologrical Society on 7 th October, IS91; see "Journ. of Conch.," vi. (1891), 398. 
Mr. Ficrke states, are scattered about the district, but are usually unproductive.

Pond at Tothby, Lincolnshive, dug in I87 I.-Particulars communicated by Mr. J. E. Mason and Mr. J. B. Davy. Of special interest from the fact that the datc of excavation is known. Situate on the clay near the foot of the Wold, in the corner of an arable field (T. C. Johnson's) at Tothby, on the borders of the parishes of Alford and Rigsby, and said to be quite isolated from other water. Two small fence-ditches, sometimes containing a little water reccived from the under-drains, open upon the pond; but Mr. Mason, in whose knowledge of the locality I have the utmost confidence, expresses the opinion that it is in the highest degrce improbable, next to impossible, that a flood should have caused a communication with any other pond or water-coursc. Of the plants, none are of kinds likcly to have been intentionally introduced; duckweed and two Potanogetons are conspicuous. Both the common newts occur, and water-bugs and beetles abound, but Mr. Mason has not secn a fish of any kind, although the nearest ponds are wcll stocked with sticklebacks. Of molluscs, Mr. Davy, in I89I, obtained two species, Limnoa peregra and Spherium lacustre, both in fair plenty. The presence of the former, which, it is said, is generally the first to appear in newly-formed ponds, ${ }^{1}$ is of no special interest, but the establishment of a bivalve-shell

1 Sec G. Koberts, "Topography and Nat. Hist. of Lofthouse," I $88:=$, p. 167. 
(S. lacustrc) in an isolated pond dug only twenty years before is certainly worthy of note.

Pond at Rigsby, Lincolnshire-Mr. Mason and Mr. Davy have also favoured me with particulars of another pond, probably much older than the last, and remarkable for possessing a surprisingly rich molluscan fauna. Situate in the parish of Rigsby (in the " nineteen acres," abutting in part on Rigsby Wood), of small size, sur. rounded by arable land, and apparently perfectly isolated. The nearest ditch, it is true, is within about cleven yards, but the water in the pond is considerably above the level of that in the ditch, and Mr. Mason assures me that no possible flood can have reached the pond; with the exception of the water carried in through the pipe-tiles of a small under-drain, it gets every drop from rain and surface drainage. It is apparently very old, and was probably dug at a time when the surrounding district was an unenclosed sheepwalk, in which case, of course, it is just possible that sheep or cattle may have been instrumental in introducing shells or ova adhering to their feet or legs.' There are no plants likely to have been intentionally introduced, duckweed (Lemna minor), a Potamogeton, some grasses, \&c., making up the principal vegetation. Mr. Davy and Mr. E. Woodthorpe, who have searched for shells, have discovered no less than four species of bivalves and five univalves, representing together five

1 The same may be said of most ponds which appear to be more ancient than the surrounding enclosures, as well as of those situate on large unenclosed pastures. 
genera: Spharinm corneum, Spharinm lacustre, Pisidium fontinale, Pisidium pusillum var. obtusalis, Planorbis nitidus, Planorbis nautilens, Limncea peregra, Limnax stagnalis, and Ancylus lacustris.

Ponds at Finchley, Middlesex.-Near the middle of a meadow at Finchley (by the side of the foot-path to Hendon, and in the third field from the road at Eastend, Finchley') are two ponds, without inlet or outlet, which lie near together upon a ridge slightly higher than the surrounding ground, perfectly isolated from other water, and which, it seems certain, can never have been affected by floods; they are evidently artificial, but probably very old, and neither is of large size, the larger measuring about $29 \times$ IO yards, and the smaller about I $4 \times 7$ yards. In the case of ponds near large towns or citics having many shell collectors one can never be absolutely certain that molluscs have not been introduced intentionally or unintentionally by human agency, but it is unlikely that this often happens, and I know of no reasonable ground for such a suspicion in the present case. Ivy-leaved duckweed (Lemna trisulca), water-thyme (Elodea canadensis), frog-bit (Hydrocharis morsus-rane), and a Potamogeton are the principal water-weeds, and there are none of kinds likely to have been planted by man. Molluscs cecur in abundance, the bivalve Spharinm corneum being plentiful in the mud, and very fine. In the larger pond four species, belonging to four genera, are found, all in good numbers :

1 This field, I find, is already being cut up for building purposes. 
Spharim corncum, Planorbis carinatus, Limnar stagnalis, and Ancylus lacustris; while the smaller one, about thirteen yards distant, contains Sphcrimm corneum, Planorbis carinatus, Limnad stagnalis, and Limnce truncatula; and some idea of their individual abundance may be gathered from the following note of four caddis-cases-selected from a number collected in both ponds - bearing, together, no less than forty-five shells. (1) Five shells attached, two of Sphcrium, one of Limncea, and two of Ancylus; (2) ten shells attached, eight of Sphcrimm, one of Plonorbis, and one of Limnea; (3) fourteen shells attached, eleven of Spherimm, one of Planorbis, and two of Limnce; (4) sixteen shells attached, one of Spharium, and fifteen of Planorlis.'

Pond rear the Black Hills, Leeds.-During a period extending over some twenty-four years Mr. W. Nelson has obtained Spharium lacustre, Pisidium pusillum, Planorbis nautileus, Planorbis vortex, Planorbis carinatus, Planorbis corneus, Planorbis contortus, Physa fontinalis, Limnea peregra, Limnea stagnalis, and Ancyins lacustris from this pond, which is of small size, isolated, as Mr. Taylor assures me, from other water, and with no inlet except "a natural drainage from the field." In times of heavy rain there is an overflow of surplus water, but this disappears in or spreads over the land

1 Mr. J. W. Taylor, of Leeds, has obligingly looked over the shells from these ponds and those at Welton-le-IVold, Tothby, and Rigsby, determining the Pisidiu, and confirming my naming of the other kinds. 
and has never been seen to reach a small stream which runs along at the bottom of the field, perhaps i 50 yards away. The shell-fauna, it will be secn, is a wonderfully rich one, comprising, as it does, cleven species belonging to six genera, including two bivalves and no less than five kinds of coil-shells or Planorbes. But the pond is additionally interesting from the fact that a number of species seem to have been introduced quite recently. During I $\$ 60-3$, when Mr. Nelson was in the habit of collecting there, it yiclded only four species, Spharium lacustre, Pisidium pusillum, Planorbis nantileus, and Limnea peregra, so that since that period its fauna scems to have received a surprising number of additions. About I873, Mr. Nelson resumed his visits to the locality and found Planorbis corneus, but no further kinds were obtained till I883, when during frequent visits, he found six others, Physa fontinalis and Planorbis vortex in the spring, Planorbis carinatus, Limnaa stagnalis, and Ancylus lacustris a little later, and finally, in June, this small, but prolific pond yielded its fifth Planorbis, Pl. contortus. Mr. Nelson, who has published these facts, ${ }^{1}$ is a collector of very great experience and a naturalist of ability, so that I dare not suggest that all the shells ultimately found probably existed in the pond, overlooked, during I 860-3, and Mr. Taylor and Mr. J. Beevers, who collected with him, agree that the four species named were the only forms in the pond at that time. The case is at least

'IV. Nelson, "Jomm. of Conch.," iv. (1893), 117. 
interesting and curious and is certainly worth giving, but I do not put it forward as of so much value for us as some of those previously referred to (the dewponds of the South I)owns for instance), for I do not think it seems so clearly to imply the existence of dispersal independently of man; on the Downs, day after day, as Mr. Reid states, "one meets only the shepherd tending the sheep, or the farmer making a short cut across the open country," and everything seems to show that shells are not likely to have been carried to the dew-ponds by human agency, but in Leeds, on the other hand, quite a number of shell collectors have resided for many years past, and it seems just possible that someone, having collected a number of molluscs for which he had no particular use, may have thrown them into the pond in question, but this, of course, is very unlikely; it seems just possible, also, I venture to think, that the conchologists who collected there during the earlier years may have unconsciously introduced some of the species adhering (perhaps when very minute) to their scoops or collecting nets, and it is at least noteworthy that Planorbes, so conspicuous among the additions, commonly thus adhere.

The presence of Limnce humilis, "by the hundreds," in a small artificial pond, fed by a windmill from a well twenty feet deep, was noted in the West American Scientist during I885; the pond, situate in the vicinity of Todos Santos Bay, Lower California, was only about ten years old, a few inches deep, and about six feet 
across, and for miles there was no natural surface water. ${ }^{1}$ Limnaa macrostoma, according to Dr. Ingalls (who communicated the fact to Mr. Binney in I860), not scen elsewhere within twenty miles, seems to have suddenly appeared in a pool, about twenty feet in diameter (entirely cut off from streams and fed by a spring), which had for years been frequented by the observer for Desmidia, \&c. ; this, he added, "comes as near a case of spontaneous generation as anything within my observation." = The Rev. James Dalton, in I86I, mentioned the finding of a dozen species of shells in a pond at North Stainley, near Ripon, at least half a mile from. any other water, and two of these, Limnea stagnalis and Cyclas caliculata, $[=$ Spharium lacustre $]$, did not, as far as was known, occur elsewhere in the neighbour. hood. ${ }^{3}$ The occurrence of shells in the isolated waters of pits, quarries, brick-yards, \&c., is notorious; Mr. Standen tells me, for instance, that some recently excavated "brick pits" at Cheetham Hill, near Manchester, though far from other ponds, swarm with common molluscs, Spharium corneum, Pisidium fontinale, Limnaa peregra, Limnca truncatula, Limnaa stagnalis, \&c. The presence of Anodonta fuviatilis in numbers in a hole, south of Dover Plains, Eastern Duchess

1 "West American Scientist" (C. R. Orcutt, editor), i. (1885), 74.

"W. G. Binney, "Land and Fresh-water Shells of North America," part 2 (1865), p. 37, "Smithsonian Miscellaneous Col. lections," vii., I $\$ 67$.

3 J. Ualton, "Zoologrist," xix. (1861), 7318-y. 
Co., N. Y., formed by peat-digging some thirty or more years previously, was noted in I889, by Mr. W. S. Teator. ${ }^{\prime}$

The presence of shells in reservoirs on high ground has been referred to as indicating dispersal by animal agencies, ${ }^{2}$ but in such cases, I suppose, there is often a possibility that the animals may arrive, perhaps as fry or ova, in the water with which the reservoirs are supplied, and, doubtless, a similar explanation very often applies in the case of shells found in artificial lakes, tanks, cattle-troughs, \&c. As illustrating the liability of shells to be carried with water, we have a statement by Mr. Jeffreys that the zebra mussel (Dreissena polymorpha) has been found in the most frequented streets of London after they have been flushed with water from the New River; and Canon Norman, quoted by the same author, saw immense numbers, in a living state, lining some iron water-pipes which had been taken up in Oxford Street ; ${ }^{3} \mathrm{Mr}$. Dyson, in 1850 , mentioned its occurrence also in most of the large water-pipes supplying Manchester from the waterworks at Beswick, in the reservoir at which place it

1 See "Nautilus," iii. (1889), 67-9; for a mention of the occurrence, in 1881 , of Margaritana margaritifera (believed to have been absent in 1861), at the island of Anticosti-presenting "a problem in the distribution of fresh-water shells which only the methods of Darwin can surmount"-see A. F. Gray, "American Naturalist," xvii. ( I 883), 325-6.

2 See Tate, "Land and Fresh-water Mollusks," I 866, p. 188.

3 "British Conchology," i. (1862), 48; and see also Woodward's "Manual," ed. 4, rep. 1890, p. 424. 
abounded,' and similarly, in Birmingham, according to Mr. Sherriff Tye, it abounds in the town supply pipes, derived, no doubt, from the reservoirs at Aston; Mr. J. Macgillivray, it may be added, once observed great numbers of Neritina fuviatilis and a Limnea in some large water-pipes which had been taken up near St. Luke's Hospital in the City Road, and other species were seen there by Mr. E. Newman, who also visited the spot.: Mr. Standen tells me that the lake in Alexandra Park, Manchester (fully seventy yards from the nearest pond), dug out of the peat and underlying clay in the open fields, lined with concrete, and destitute of introduced plants-filled through pipes with Manchester supply water - was found to contain, within two or three years after its excavation, Spharia and Pisidia, together with Planorbis spirorbis, Planorbis vortex, Planorbis carinatus, Limnce peregra, and Limncea palustris, all in good numbers, and the great upper lake at Belle Vue Gardens, Gorton, he says, similarly formed and filled with water, now contains Spharium corneum, Pisidium annicum, Bythinia tentaculata, Valvata piscinalis, Planorbis albus, Planorbis carinatus, Limnaa peregra, and Limncea palustris. Physa gibbosa [genus Bulinus] was taken abundantly, in 1887 , in an iron tank, "supplied with city water," on the roof of a sugar refinery in Sydney; ${ }^{3}$ the water probably came, as Mr. Musson tells me, either from the Botany Swamps

1 Dyson, as quoted by R. Standen, "Naturalist," I 887, pp. I 59-60.

2 J. Macgillivray, "\%oologist," X. (I \&52). 3420.

3 Stcel, "Proc. Lin. Soc. N.S.IV.," (2), ii. (1 $\delta S 8), 196$. 
or the Nepean River, in or near both of which the shell is not at all uncommon. At Burnley, it is said, Planorbis dilatatus has occurred in thousands, together with nine other molluscs, Spharium corneum, Sphcerium lacustre, Valvata piscinalis, Bythinia tentaculata, Limncer peregra, Planorbis albus, Planorbis comeus, Planorbis nitidus, and Planorbis glaber, in a cistern on the top of an engine-house, "about sixty feet above the canal from which the water is pumped." $M$ Mr. Musson, on the authority of a member of the Nottingham Naturalists' Society, states that a water-butt on Blue Bell Hill, Nottingham, fed, until about I 882 , from the corporation reservoir at the top of Elm Avenue, contained no shells, but when the source of supply was changed from Nottingham to Pappiewick, Limnea truncatula soon made its appearance in tolerable abundance, and Limnce peregra, also, was discovered.

Shells are quite commonly found in horse and cattletroughs, and their occurrence in such places has been noted by many writers. Mr. Roebuck, for instance, mentions having found Limnce peregra in a new watertrough on the summit of the Great Orme's Head." Mr. W. A. Marsh has referred to the presence of Limnea parva in a horse-trough at his barn-well (in Mercer County, Illinois), nowhere near any pond or slough; how they happened to be found there, he adds, "remains a mystery." 3 Mr. Reid remarks upon

\footnotetext{
"F. C. Long, "Science Gossip," xxiv. (1888), 28 I.

: W. D. Roebuck, "Journ. of Conch.," iv. (18\&4), 209.

3 W. A. Marsh, "Conchologists Exchange." ii. (1888), 110.
} 
the fact that Limnea truncatula "has a curious tendency to turn up in horse-troughs and stone basins;" in one instance, he found a number in a raised stone cattle-trough on the marshes of the Humber, where the dykes contained water much too salt for cattle to drink, and a supply had to be provided by deep borings, one of which overflowed from the tube into the trough in question; thus, as he states, "a small colony of $L$. truncatula was found living in a cattle-trough in the middle of a salt-marsh, where the surrounding dykes were too salt for this snail to live in." "In I 890, Mr. C. R. Orcutt recorded the finding of thousands of living Physe in a tank (with a capacity of four thousand gallons) which had been erected, not quite a year previously, by a mining company at Hanlon's Ferry, south of Ft. Yuma, on the west bank of the Colorado River, California. This tank, it is stated, was supplied "from a six inch well," and "no shells were found alive in the Colorado River only a few hundred feet away."

It will doubtless be admitted, as already suggested, that shells found in situations of the present kind (reservoirs, artificially-filled lakes, tanks, troughs, \&c.) are in many cases carried in with the supply-water, but it would frequently be found difficult, in individual cases, to ascertain whether a possibility that such is the case really exists. Transportal in this way, to say the least, scems improbable in the three cases

${ }^{1}$ C. Reid, "Trans. Norfolk and Norwich Nat. Soc.," v. (1892), 279.

"C. R. Orcutt, "Nautilus," iv. (1890). 67-S. 
last mentioned, and certainly there is no such possibility in a further case which Mr. C. P. Gloyne has obligingly communicated. In Jamaica (where Mr. Gloyne resided for some years) is a district in which-owing to the rain percolating through the porous limestone and escaping subterraneously - there is no natural standing or running water; a supply is obtained, however, from artificial cemented-tanks, which receive the rain-water from the "barbecues" (sloping planes, also cemented, for drying coffee, \&c.) and from the houses, and in all these tanks, having, as I am assured, no connection whatever with each other, one and the same species of Physa, of which Mr. Gloyne forgets the name, makes its appearance! Hardly less remarkable, perhaps, is the presence of pond-snails in the basins of both the fountains in Trafalgar Square, erected in I 845 , and supplied from two Artesian aeells, one behind the National Gallery, and the other immediately in front of it.' Within nine or ten years after their construction, the basins were known to contain shells, for, about the year I854, Mr. E. L. Layard exhibited specimens of them at a meeting of the Zoological Society, and, notwithstanding the fact that the basins are said to be frequently cleaned out, I found Limmac peregra still living there, in I89I, in good numbers. A very small fish and a water-beetle, no doubt an Acilius, were also seen, but there were no weeds. Artesian wells have been known to send up seeds, small fish, and shells of several kinds, including,

1 See "Old and New London," (Cassell), iii. I42; "Builder," ii. (1844), 370, and iii., (1845), il I. 
in one instance, a specimen of Planorbis marginatus $[=P l$. complanatus $]$ presumably dead, and living fish arc said to have come up from a depth of $175 \mathrm{fcet},{ }^{1}$ but I am assured that no such underground transportal to Trafalgar Square is likely to have taken place. Mr. Layard has suggested that the Limnae were brought to the basins from the ornamental water in onc of the parks, "attached to the feathers of the sparrows who bathed, first in onc and then in the other." " When the fountains ceasc to play, as I was told by a policcman on duty in the square, many birds-both sparrows and pigcons-bathe in the small upper basins from which water falls into the large basins in which the Limneee are scen. It seems just possible, however, as Mr. Reid has remarked to me, that "some misguided naturalist with a mania for 'acclimatization' may have placed some snails in the basins, or one of the boys who will try to catch fish there may have brought his line straight from the park with the small snails or eggs attached."

Aquatic molluscs, as is wcll known, commonly live in marshes and swamps which are dry during a great part of the ycar, and they occur also in other nonpermanent watcr, in that collected in hollows after rains, in roadside puddles, Src. When the water is derived from the overflowing of rivers the presence of the animals is easily understood, for they are known to be carried from place to place with flood-water; their

1 See "Lyell’s Principles," ed. I2, i. ( I 875), 390-I.

"E. L. Layard, "Nature," xxxviii. ( 1888 ), 296. 
occurrence in waters derived exclusively from the rainfall of the immediate neighbourhood, however, has often been regarded as surprising and mysterious. But we must not fall into the error of concluding that the creatures are necessarily introduced, after the appearance of the water, by accidental means of dispersal, for it is stated that they are able to remain alive in a torpid state for long periods buried in the mud, and that on the return of water to the surface they are ready to burst into activity with remarkable rapidity. Their almost immediate appearance after the occurrence of rain, in tropical countries, in swamps and hollows which have long remained dry is, I understand, quite familiar to the naturalists of those regions. Adanson states that a minute fresh-water shell (which he calls Bulimus) is to be seen only from September to January in the marshes of Senegal which are formed by the rains of June, July, August, and September; when the marshes dry up the animals disappear, a few empty shells alone remaining upon the surface, but they never fail to return with the rainy season.' Major Becher, in a paper on the mollusca of the Maltese Islands, mentions the finding of Limnea truncatula in small hollows, the mud of which, in summer, "must be baked till it becomes almost brick." " Mr. W. A. Marsh records the finding of Limnea humilis (said by some to be the same as L. truncatula) in ponds on his land, in Illinois, which

"Hist. Nat. du Sénégal," p. 7, as quoted by Dr. Johnston in "Loudon's Mag. Nat. Hist.," vii. (1 834 ), I I 5.

"E. F. Becher, "Journ. of Conch.", iv. (I884), 23 I. 
had been dry for three years at a stretch; when the water reappeared in the fourth year the little mollusc seemed as abundant as ever. Limnaa parva, also, was seen by the same naturalist in considerable numbers about the margins of small basins which had been dry for three or four years. ${ }^{1} \mathrm{Mr}$. W. Jeffery, in a paper on the mollusca of Western Sussex, remarks upon the presence of Limnad truncatula wherever a roadside stream trickles down in spring, no matter at what elevation, and notwithstanding the fact that the water is almost sure to be dried up in summer, and he mentions having seen specimens in a marl-pit far from any permanent water." Mr. H. C. Leslie has recorded the finding of about half-a-dozen full-grown specimens of Limnaa peregra in a puddle, containing some two or three gallons of water, formed by the breaking out of a small spring by the roadside on one of the hills near Erith, ${ }^{3}$ and the same species has been noted by Mr. Roebuck as common in roadside puddles between the Orme's Heads, and elsewhere, in Wales. ${ }^{4}$ Sir C. Lyell, in one of his published letters, states that "Lymnea truncatella," introduced unintentionally by the Portuguese into Madeira, went all over the island in thirty years, and was said to have appeared even in pools and ruts in the roads; if this be so, he adds, the creature has powers of spreading "which require investiga-

? W. A. Marsh, "Conchologists' Exchange," ii. (I8SS), I Io.

" W. Jeffery, "Journ. of Conch.," iii. (I8S2), 3 I I-I2.

3 H. C. Leslie, "Science Gossip," I 870, p. I 37.

+ IV. D. Roebuck, "Journ. of Conch.," iv. (1884), 209. 
tion." " Some Limnace, \&c., we must remember in connection with these facts, are not altogether incapable of migration on land, for they are nearly amphibious; Limnac peregre, for instance, Mr. Jeffreys states," as its name imports, is "fond of wandering and seeing a little of the world," and Limnae truncatula, it is even said, is "more frequently met with out of the water than in it."

1 "Life, Letters, and Journals of Sir C. Lyell, Bart.", ii. (I88I), 209, 212 , in letters dated 1856 .

" "British Conchology," i. (1862), 107, I16. 


\section{CHAPTER II.}

\section{MEANS OF DISPERSAL.}

THE manner in which fresh-water shells are distributed over the globe, the wide ranges enjoyed by many, and their local diffusion in isolated waters, as we have seen, clearly imply the existence of means of dispersal. The creatures must certainly have been carricd from pool to pool, from river-basin to river-basin, and from mainland to island, even, indeed, to some of the most isolated archipelagoes of the open ocean.

Objections to suggested means have sometimes been raised on the ground that the creatures would probably be unable to withstand the exposure to which they would be subjected, but, as is pretty generally known, many kinds, at least, are able to live for a time out of water, and under the most adverse conditions. Of a number of pond-snails (Limnae truncatula), for instance, placed by Professor A. P. Thomas in an open vessel, in a dry laboratory, where the sunshine fell upon them for an hour or so daily, rather more than fifty per cent. survived for twenty-six days, and some few were alive after more than six weeks.' A specimen of Paludina

'A. P. Thomas, "Quart. Journ. Micro. Sci.," (n.s.), xxiii. (I883), 131. 
vivipara, an operculate water-snail, as Mr. R. M. Christy states, accidentally cjected from an aquarium and allowed to remain for more than three weeks on the ground in a field, on being restored to its fellows secmed to have taken no harm.' Some Ampullarice, placed in a drawer by Mr. Laidlay, are even said to have survived, in the warm climate of Calcutta, for five years!" A freshwater mussel (Anodonte) once arrived alive in France after having been wrapped up in dry paper for cight months during its voyage from Cochin-China," and an Australian Unio, rescmbling our "swollen fresh-water mussel" (Unio tumidus), having already survived in a dry drawer for 23 I days, packed up (after being tested in water) and forwarded to England, reached Southampton in a living state 498 days after its capture, and was subsequently "restored to its element, with full vital powers," in the care of Dr. Baird, of the British Museum." This great tenacity of life, common to many kinds, of which quite a number of instances might be given, must certainly have largely facilitated dispersal.

1 R. M. Christy, "Zoologist," (3), v. (188r), r8r.

2Woodward's "Manual," ed. 4, rep., I 89o, p. I4.

3 "Journ. de Conch.," xxiii. (1875), 81-4, as quoted in "Quart. Journ. of Conch.," i. p. 78, and "Zoological Record," xii. (I875), 136.

4 Probably, according to Mr. Musson, $U$. ambiguns or $U$. australis.

5 J. S. Gaskoin, "Proc. Zool. Soc.," 1850, pp. 243-4, and see also Woodward's "Manual," ed. 4, rep. I890, pp. I3-I4.

"See, for example, J. L. Hawkins, on Limncea stagnalis, "Science Gossip," xvii. (I 88r), 23; Jeffreys, on Sphcerium lacustre, "British Conchology," i. (1862), 1 I-12 ; Baker Hudson, on Spher. 
But we must inquire as to the means by which the creatures have been diffused. The problem, everyone is aware, is an old one, and has been answered or partially answered by many writers; Sir C. Lyell attended to it, as also did Mr. Darwin, and many naturalists have followed in the footsteps of these distinguished authors.

In early life, collecting in the fresh waters of Brazil, Mr. Darwin noted with surprise the similarity of the fresh-water insects, shells, \&c., and the dissimilarity of the surrounding terrestrial forms of life, as compared with those of this country; and questions as to the diffusion of the former seem to have been more or less prominently before his mind during many years; a letter on means of dispersal of bivalves, one of his latest published writings, appeared in "Nature" only thirteen days before his death. In the "Origin" he expressed the belief that the wide ranging power of fresh-water productions could be explained, in most cases, "by their having become fitted, in a manner highly useful to them, for short and frequent migrations from pond to pond, or from stream to strcam, within their own countries," and liability to wide dispersal, he remarked, "would follow from this capacity as an almost necessary consequence." ${ }^{1}$ The way in which such migrations are

rium comeum, "Science Gossip," xx. (ISS4), 9I ; C. T. Simpson, on Unio, \&c., "Conchologists' Exchange," ii. (1887), 50 ; E. B. Sanger, on an Australian fresh-water mussel, "American Nat.," xvii. (1S83), I $84-5$; and J. E. Gray, on Dreissence polymorphu, "Annals of l'hilosophy," ix. (1825), 139.

1 "Origin," p. $3+3$. 
probably effected was discussed in some detail, and diversified and curious means of dispersal were shown to be in operation; as regards molluscs, facts were given suggesting transportal, possibly over the sea, by aquatic birds and insects; ${ }^{1}$ and subsequently, in I882, when publishing several additional facts indicating dispersal by animal agencies, Darwin demurred to the belief, which had been somewhat doubtfully expressed by Mr. Jeffreys, that the diffusion of fresh-water shells " had a different and very remote origin, and that it took place before the present distribution of land and water." :

Much diffusion, of course, as Darwin admitted, must be attributed to changes in the level of the land, "within the recent pcriod, causing rivers to flow into each other." ${ }^{3}$ Streams belonging to distinct systems, Mr. Wallace has remarked, often approach and might bc made to change their course from one to the other basin by vcry slight alterations of level. During the glacial epoch, icc, blocking up valleys, compelled streams to flow over watersheds to find an outlet. ${ }^{4}$

The carrying powers of floods, as wcll as of rivers in their ordinary action, are doubtless very great, and must have largely influcnced distribution. Professor Ralph 'Tate, indeed, long ago cxpressed the opinion that the

' "Origin," pp. 344-5.

"Darwin, "Nature," xviii. (1878), 120-1; xxv. (1882), 529-30; Jeffreys, "British Conchology," i. (1862), 1xxx.

: "Origin," p. 344.

4 Wallace, "Island Life," (1880), pp. 74 and 324; cd. 2, pp. 76 and 344 . 
diffusion of fresh-water shells had been chicfly effected by "streams and land-floods;" "but the influence of these agencies, it should be remembered, must be confined, to a great extent, within the limits of river-basins; in some parts of the world, however, floods are known to connect low watersheds. Unusual rushes of water must certainly wash away large numbers of shells and carry them down stream, possibly to great distances. Every shell collector knows that ditches and pools lying near to rivers, and liable to be affected by overflows, are generally stocked with more species than those on high ground, far from the larger water-courses. In Nottinghamshire, for instance, Mr. Musson has remarked, the greatest number of species can be obtained from those parts of the Trent Valley which arc subject to flooding, and, in fact, nearly every species recorded for the county can be collected in the meadows between Colwick and Beeston, while on the other hand, the species found in ponds unconnected with the general drainage system are comparatively few. Many facts illustrating transportal by floods might have been got together. A variety of Ancylus fluviatilis was noted at one time as very abundant on stones in shallow places in the River Went, but a strong flood, it is said, "swept nearly all the stones and shells away." " Mr. L. E. Adams has described a flood in the Thames which brought down large quantities of shells, comprising

1 'Tate's "Land and Fresh-water Mollusks," I S66, p. I $\$ 8$.

$2 \mathrm{~J}$. Wilcock, as quoted by Mr. George Roberts, "Zoologist," (3), ix. $(188 j), 47 j$. 
twenty-three fresh-water and twenty-four land species; the greater part were "dead and worthless," but some of the aquatic kinds, it appears, were still alive." Limnac truncatula, Mr. Jeffery has remarked, "has a habit of following the flow of water during floods," and often gets left high and dry." During the summer of I88I, Professor Thomas, studying the life history of the liverfluke, and anxious to try infective experiments with this snail, scarched repeatedly for it in the neighbourhood of Oxford, trying the localities in which he had formerly found it, and those given in Whiteaves' list, but only empty shells could be discovered. In I882, however, there were floods in July, and the creature came down in vast multitudes with the waters of the Isis; so numerous was it that, several times, a single sweep of a small hand-net gave more than 500 examples, and this in a ditch where the year before not a single specimen could be found; all along the margins of the ditches it occurred in the greatest profusion, and it was found in numbers on the land after the floodwaters had retired. ${ }^{3}$ Mr. W. A. Marsh, in his valuable notes on the land and fresh-water shells of Mercer Co., Illinois, mentions that Limnae reflexa (common in the small lakes of the county and in some of the larger ponds in the Mississippi River bottom) is carried out of the lakes in times of very high water, and may then

1 L. E. Adams, "Science Gossip," xvii. (1881), I 8.

¿ W. Jeffery, "Zoologist," (3), ii. (1878), 181.

3 A. P. Thomas, "Quart. Journ. Micro. Sci.," (n.s.), xxiii. (1883), $105.6,130-1$. 
be found in considerable numbers along the margins of the river, clinging to limbs of trees and pieces of bark; vast numbers of Pleurocera subularis (which abounds in the small lakes of the Bay Island, \&c.), he also states, are to be found in July and August along the margins of the river, clinging to drift-wood, having been carried by a sudden rise in the waters from the different lakes in the Bay.' Cooper's Creek, Central Australia, according to Mr. E. B. Sanger, yields, amongst other things, gastropods of three genera, "Physa, Paludina, and Tryonia," which (he believes) die when the water dries up; each flood, however, is found to stock the creek again by bringing down young ones, which, it is important to notice, are actually to be seen, "in all stages of growth, in the flood-water." 2 As showing that Unionidee are carried over land by floods, $\mathrm{Mr}$. C. T. Simpson instances the finding of a Unio in great numbers in low places and drains in the piney woods of South Florida, at quite a distance from any stream, where not a drop of water is to be seen outside, perhaps, of three months of the rainy season, and where, during the remaining nine months of the year, the animals must have lain dormant in slightly damp sand; he had dug them out in such places during the dry season by the bushel. ${ }^{3}$ Similarly, Mr. Cuming is said to have collected living specimens of Cyclas maculata while

I W. A. Marsh, "Conchologists' Exchange," ii. (1887-8), S1, 103.

" F. B. Sanger, "American Nat." rvii. (1883), I $184-5$.

3 C. I. Simpson, "Nautilus," v. (1891), 16. 
searching for land-shells in a garden in Old Panama, where, it is stated, "they had been left after the rainy season," "and the occasional occurrence of living Pisidia on land, at some little distance from water, is familiar to many observers. A little observation, recently recorded, on the transportal of a shell by a mountain torrent is perhaps worth giving. A house in which an English naturalist stayed in Trinidad had a bath-room constructed so that a rapid stream (under control) flowed in at one end and out at the other, and here, it is said, the bather was joined sometimes by a specimen or two of the "ram's-horn water-snail," which "would occasionally come toppling down the rushing waters to a deeper and quicter portion of the channel below." :

Shells adhering to detached and floating water-plants seem eminently liable to transmission by rivers, and when swept away during floods may be carried occasionally to ponds or other waters at a considerable distance from the river-bed. It is interesting to note that a handful of dead pond-weed (Potanogeton), which was floating in a ditch and might have been carried to a great distance in some circumstances, was once found by Mr. W. K. Bridgman to contain "about a tablespoonful" of little nautilus coil-shells (Planorbis imbricatus)! ${ }^{3}$ Live shells, it is well known, are frequently

1 Reeve, "Land and Fresh-water Mollusks," I S63, p. 236.

2 H. H. Higgins, "Address to Liverpool Naturalists' Field Club," Jan. 30, 1891 , p. 17 .

${ }^{3}=$ Planorbis nautileus; W. K. Bridgman, "Zoologist," ix. $(1851), 3302$. 
found upon the cases of caddis-worms: on some of those from the pondsat Finchley, before mentioned, were several living specimens of Spharium cornemn; indeed, with Limnephilus flavicornis, which makes most of the shellcases so common in our fresh waters, as Mr. McLachlan has observed, it matters little whether the shells are empty or still contain the living animal.' After the fly has emerged, the empty cases, in all probability, are sometimes floated to great distances, but the molluscs may not always survive until set free by the rotting of the binding materials. In March, I892, I saw a number of empty cases, bearing shells of Sphcerium, Pisidium, Bythinia, Valvata, Planorbis, Limnea, Ancylus, and Succinea, floating amongst débris at the margin of an overflow by the Lea, but I could not ascertain that any of the shells contained living animals. It is notorious how often shells and shell-bearing caddiscases are found adhering to the under-sides of floating trunks and branches of trees, or hidden away in their crevices, and in such positions the creatures are often likely to be carried to considerable distances, sometimes, perhaps, for hundreds of miles. Those molluscs which habitually float, foot uppermost, on the under-surface of the water are sometimes drifted along by stcady currents. Mr. George Roberts has remarked that Limnea peregra "frequently allows itself to drift on the surface of run-

1 R. McLachlan, "Science Gossip" for 1868, pp. 152.3; and see "Science Gossip" for 1866, pp. 95 and 110; George Roberts, "Topography and Nat. Hist. of Lofthouse," 1882 p. $23 \delta$. 
ning water," "and in an old canal north of Inchbroom, Mr. Martin ${ }^{2}$ is said to have seen hundreds of snails of this species sailing from one end of the canal to the other, resembling "a fleet of herring-boats in miniature." In a pond in Yorkshire, Mr. Christy observed that this snail often crawled on the top of the duckweed in mild weather and was liable to be blown to one end of the pond by the breeze in large numbers. ${ }^{3}$ The free-roving larva of Dreissena, for a time, live chiefly near the surface of the water, and, as Dr. Korschelt observes, are likely to be carried forward for long distances by currents. ${ }^{4}$ Univalves frequently attach their eggs to loose leaves and sticks in the water, and these, as Sir C. Lyell states, "are liable to be swept away, during floods, from tributaries to the main streams, and from thence to all parts of the same basin ;" a species, it is added, might thus migrate during one season from the head-waters of the Mississippi, or any other great river, to countries bordering the sea at the distance of many thousands of miles. Figures given by Lyell show the ova of an Ampullaria fixed to a small sprig which had fallen into the water, those of a Planorbis attached to a dead leaf, and those of a Limncea adhering to a dead stick." In a pool in Epping Forest I recently saw "egg-jellies" of Limnaa auricularia

1 "Topography and Nat. Hist. of Lofthouse," I 882, p. 242.

2 Quoted by the Rev. G. Gordon, "Zoologist," xii. (1 854 ), 4457.

3 R. M. Christy, "Zoologist," (3), v. (1881), I 84.

4 E. Korschelt, "Ann. and Mag. Nat. Hist," (6), ix. (1892), 166.

$s$ "Principles," ii. p. 380 , fig. 142. 
adhering to every available object; a detached brackenfrond lying in the water could only be described as literally covered; I tried to count the number of masses upon it, but soon gave up the task; there were hundreds, and possibly each contained from fifty to sixty eggs. ${ }^{2}$ An object of this kind, one can readily imagine, if near a stream which occasionally overflowed, might easily be carried away with the flood-water, and, if it happened to reach a pond or other water where the conditions were favourable, the introduced species could hardly fail to establish itself in the new home.

Mr. C. T. Simpson has even expressed the opinion that in some parts of the world trees, \&c., drifted down by rivers and floods, may occasionally float fresh-water molluses in safety over the sea. In his own words:

"Great numbers of trees are washed out and lodged along the rivers and torrents of tropical countries; and in the crevices of the bark of these trees many species of fresh-water shells find a home. Others live among the roots of living trees which are washed by the water of streams. In Florida I have collected handfuls of Unio fuscatus and other species among the matted roots of trees just under the surface of the water. Such trees, washed out and carried down stream, would take some of their molluscan inhabitants with them. Others, carried in floods, with broken jagged limbs and loosened bark, would plow up quantities of mud and shells from the bottom and carry

'See "Rimmer," p. 62. 
them out to sea. Some such trees might drift into bays at the mouths of rivers in other countries, and I have scen just such floating in the mouths of the Manatce and Caloosahatchee Rivers in Florida. It must be remembered that all these rivers, during the rainy season, are only very slightly brackish, or even entirely fresh, throughout their estuary portions.

"Trees carried into such places, and bearing freshwater shells, might be driven up and landed by tide and winds, and a colony of living inhabitants established. Many of the shallow bays along the coast of Florida become perfectly fresh during the rainy scason, as some five feet of water falls there in three months, and the same thing no doubt occurs in other parts of the tropics where the rain-fall is much greater. In Floricla these bays at such times connect with ponds of water on the flat lands, so that often for miles the whole country from the shore far inland is nearly covered with fresh water.

"At the south-western extremity of the State are found the Ten Thousand Islands, an innumerable group scattered over a space of a hundred and fifty miles of coast separated by brackish channels through which the tide flows in and out, gradually bccoming entirely fresh in the region of the Everglades. So there would be no trouble about landing a colony of fresh-water snails on the Florida coast, and the only difficulty would be in bringing them across. Could they stand the drying and the salt water of the occan?"

[After showing that many kinds are able to live for a 
long time out of water, the author proceeds to remark, by way of answering the latter half of his question, that] "many fresh-water species will live in brackish water, as is well known. Neritina reclivata, found in Florida, seems indifferent as to whether it lives in fresh water or that which is more or less salty, and $N$. lineolata and macrostoma, which I found in Honduras in the mouths of rivers, often . extended into the sea. Planorbis tumidus was often found in slightly brackish water in Florida, and the Limmaas in the Baltic and some places on the British coasts mingle with the Littorinas. "Ampullaria caliginosa, a Mexican species, closely related to $A$. depressa, if not identical with it, Planorbis tumidus and havanensis (identified by Mr. H. A. Pilsbry, who has made a special study of the genus Planorbis), and a few other tropical species found to-day in the Southern States, may have been introduced, I think, in the manner of which I have spoken. Of course such voyages of living snails, with a successful termination, could only happen rarely, but it must be remembered that countless ages have elapsed since the present species have occupied the earth." '

That both adult shells and their ova are frequently carricd out to sea with drift timber, brushwood, \&c., cannot be doubted for a moment, but it is not actually known, I belicre, that any mollusc from a truly freshwater habitat can endure much exposure to the waters of the ocean. More direct experiments on the

C. 'T. Simpson, "Conchologists' Exchange," ii. (1887), j0-I 
point are probably required, but I find it stated both by Darwin and Wallace that salt water is immediately or almost immediately fatal both to ova and adults. ${ }^{1}$ It seems improbable, therefore, that the creatures are transported for any considerable distance over the open sea in the way indicated. Molluscs belonging to fresh-water genera or species, but inhabiting water which is salt or brackish, might almost certainly be thus carried, and in a new home in the course of ages some of their descendants might re-adapt themselves to fresh water. But we cannot argue that, because certain members of a genus live in salt or brackish water, other members from fresh-water habitats are likely to withstand a voyage over the sea; nor in the case of freshwater species having individuals living in the sea or in brackish estuaries, in certain spots, can it be supposed that examples from fresh waters could pass through the sea unharmed. Some of the fresh-water species of Neritina, as Dr. H. B. Guppy remarks in his "Solomon Islands," have been widely dispersed, Neritina subsulcata and $N$. cornea occurring both in the Solomon Islands and in the Philippines, $N$. macgillivrayi and $N$. petiti in the Fiji and Solomon Islands, and $N$. porcata in Samoa and Fiji, as well as in the opposite extremities of the Solomon group; yet it is doubtful whether the animals have been drifted far over the sea, for although possessing a stony and close-fitting operculum they are probably unable to resist the action of salt 1 "Origin," p. 344; Wallace, "Geographical Distribution," i. p. 3 I. 
water for any length of time; one individual of $N$. subsulcata survived submersion for twelve hours, but of a dozen kept in water, changed from time to time, for five days, not one survived. It has been pointed out, however, that these animals have calcareous egg-capsules which are probably thick enough to resist salt water, and these, as Mr. Edgar Smith has remarked, if attached to floating timber, might be carried to considerable distances. ${ }^{1}$

Something, no doubt, may be attributed to the agency of floating ice, for varicus kinds of shells have been known to revive after having been frozen up. Dr. Binney states that a Succinea "has been frozen in a solid block of ice and yet escaped unharmed." Anodonta cygnea and Paludina vivipara, also, M. Joly has observed, may be kept frozen up for some time without being killed, ${ }^{3}$ and the latter has even produced young after being thawed. ${ }^{4}$ In some thick ice which Mr. W. A. Gain once removed from a stone trough or "out-door aquarium," and allowed to melt slowly, were

1 H. B. Guppy, "Solomon Islands," I887, pp. 338-9 ; E. A. Snith, "Proc. Zool. Soc.," 1885, p. 588. 196.

"A. Binney, "Terrestrial Air-breathing Mollusks," i. (1851),

3 On the other hand, however, it is stated that two specimens of A. cygnea, exposed in the winter of I890-I, in an open vessel, to the entire severity of the frost, were killed, their shells splitting from dorsal to ventral surface on one side (see "Nature," xliii. (1891), 464), and I have found several mentions of the fatal effects of severe frosts upon bivalves in a state of nature.

4 "Comptes Rendus," xvi. (1843), 460, as quoted in "British Conchology," i. (1862), xliv. 
many young examples of Limnce peregra and L. stagnalis, ready to crawl away as soon as they dropped from the blocks, and Planorbis corneus and P. complanatus also occurred in quantity, mostly young, and all living. The water had been frozen for six weeks, and it is probable that most of the animals had been at least a month in solid ice. A few specimens of Pisidium pusillum, also frozen up, had died.' We have here a means by which the animals may almost certainly cross arms of the sea, for when enclosed in ice they would be effectually protected from the injurious effects of salt water. Dr. Guppy has suggested, also, that molluscs burying themselves in winter in the mud at the bottoms of rivers, \&c., may possibly be transported, even across the sea, in the frozen mud buoyed up by ice. In the shallow waters of the Lea, he has noticed that after a frost of some duration, when the water was frozen to the bottom, the mud beneath for an inch or two was also frozen, so that on lifting up a slab of the ice, a layer of frozen mud, an inch or two thick, formed the lower part of the mass. But it seems hardly likely that the creatures will often be landed by these means on foreign shores in localities suitable for the establishment of new colonies. Quite possibly, however, on the breaking up of frosts, shells thus enclosed in ice or frozen mud may be safely carried, within their own river-basins, to great distances.

Powerful whirlwinds, according to Sir C. Lyell, some-

1 W. A. Gain, "Science Gossip," xxvii. (1891), I I8. 
times dry up lakes and ponds, ${ }^{1}$ and fishes still alive, as Darwin states, are not very rarely dropped by them at distant points," so that we are justified, perhaps, in assuming that the distribution of shells has been influenced by such means. There are many authentic accounts, it is said, of the falling of fish from the atmosphere; ${ }^{3}$ and frogs and other creatures, no doubt taken up by whirlwinds or hurricanes, have been seen to fall in "showers." On the 9th of February, I859, for instance, a shower of small living fish appears to have fallen in the valley of Aberdare. A sawyer at work in Messrs. Nixon and Co.'s yard (whose statements were taken down on the spot by the Vicar of the parish), while getting out a piece of timber for the saw, was startled by something (which he found to be little fish) falling all over him; and a long strip of ground, it is said, soon became covered with the creatures, " jumping all about;" many were seen, also, on the top of a large shed, etc. Numbers were gathered and thrown into a rain-pool, where some were to be seen when the evidence was taken. The wind at the time of the shower was not very strong. but it was "uncommon wet," and the fish came down with the rain "in a body like." Mr. R. Drane, of Cardiff, who investigated the case, is said to have obtained convincing evidence, from other sources, that a large number of fish actually descended with the rain, and over a considerable tract of country; specimens procured from three persons resident some

1 "Principles," ii. p. 392.

2 "Origin," p. 344 .

3 Wallace, "Geographical Distribution," i. p. 29. 
distance from each other were of two species, the common minnow and the three-spined stickleback.' To give another instance, the late Thomas Cooper (well known to many through his delightful autobiography) witnessed, when a boy-with others-a shower of frogs, which, "jumping alive, fell on the pavement at our feet, and came tumbling down the spouts from the tiles of the houses into the water-tubs;" he was as sure of what he had seen as of his own cxistence, and recorded the fact because it had been stated in books that such a sight was impossible. ${ }^{2}$ Water-beetles, also, are said to have fallen in showers," but I am not aware that aquatic molluscs are actually known to have done so.

'J. Griffith, "Zoologist," xvii. (1859), 6493; R. Drane, p. 6564.

2 "Life of Thomas Cooper," pp. 20-I, as quoted in "Science Gossip" fur I872, p. I67; and see on this subject Gosse's "Romance of Natural History," second series, I86I.

3 See "American Entomologist, (2), i. (1880), 248; "American Nat.," xvi. (I882), 600.

"A case has been recorded since the above was written. See "Nature," xlvii. (I893), 278: "Das Wetter of December last contains an account of a heavy thunderstorm which occurred at Paderborn on August 9, I892, in which a number of living pond mussels were mixed with the rain. The observer, who is in connection with the Berlin Meteorological Office, sent a detailed account of the strange occurrence, and a specimen was forwarded to the Museum at Berlin, which stated that it was the Anodonta anatina (L.). A yellowish cloud attracted the attention of several people, both from its colour and the rapidity of its motion, when suddenly it burst, a torrential rain fell with a rattling sound, and immediately afterwards the pavement was found to be covered with hundreds of the mussels. Further details will be published in the reports of the Berlin Office, but the only possible explanation seems to be that the water of a river in the neighbourhood 
Animals of various kinds, it can hardly be doubted, are actively engaged in dispersing shells. The "short and frequent migrations from pond to pond or from stream to stream," to which Mr. Darwin has alluded, have, almost certainly, been largely brought about by birds and other creatures, and transportal by such agency over considerable tracts of ocean, it has been shown, is at least possible. Many birds, fish, amphibia, etc., swallow large numbers of shells, which are sure, in some cases, to survive for a time in their stomachs; thus, for instance, Mr. Baker Hudson has often found living Pisidia, with their valves tightly closed, in the stomachs of frogs, and this, of course, suggests a possibility that sudden deaths of shell-eating creatures, brought about by birds and beasts of prey, may have led, at rare intervals, to the setting free of living shells in spots considerably removed from their original homes; and some birds, it is important to notice, on being frightened or wounded, occasionally or habitually cast up the contents of their crops. That shells are voided in a living state with the excrement seems less likely, for they are almost sure to be killed during their passage through the digestive organs. No less a person than Dr. Kobelt, however, has ventured to express the opinion that small mussels and even sometimes operculate water-snails, when swallowed alive by birds, may possibly pass the intestines unhurt. ${ }^{1}$ Experiments on

was drawn up by a passing tornado, and afterwards deposited its living burden at the place in question."

W. Kobelt, "Fauna der Nassauischen. Mollusken," I871, p. I4. 
the point appear to be required, but I can hardly think that anything other than negative results will be obtained.' Four warty-newts, placed in a vessel of water by Mr. C. Robson, extruded a number of Pisidia, the shells of most of which were open, with the animal extracted; four, however, were closed, and three of these contained young; the adult animals had been extracted even from these closed shells, but, in some of the young, the animals were still within the shells, yet it does not appear that they were actually observed to be alive. ${ }^{2}$ As far as diffusion by animals is concerned, it seems clear, I think, that the creatures are chiefly carried while very young, adhering to the feet and feathers of aquatic birds, or attached to plants thus adhering. Adult and partly grown shells, however, are liable to occasional transportal by creatures of various kinds, and, through the agency of birds, adult bivalves, even some of the larger kinds, may sometimes be carried through considerable spaces; but before giving the facts on this head we will consider the possible dispersal of fry and ova.

Mr. Darwin has a statement at page 344 of the "Origin" that the eggs are not likely to be transported by birds; but Mr. Wallace, Professor Tate, Lieut.-Col. Godwin-Austen, and other writers have referred to

1 The eggs of Limnaca auricularia, it has recently been stated, have passed unharmed through the digestive system of swans. See "Zuological Record," xxviii. (s 89I), Moll. p. 37, referring to Pascal, "Journ. de Conch.," xxxi. pp. 9-I 5.

"C. Robson, "Science Gossip" for I 875, p. 220. 
such transportal as probable, ${ }^{\prime}$ and Canon Tristram, in the winter of $1856-7$, it is interesting to find, had the good fortune to discover the eggs of some molluscprobably Succinea-attached by their glutinous coating to one of the feet of a passing mallard shot by him in the Sahara, a hundred miles from water ${ }^{2}$ thus, he remarks, such a bird "might easily carry a Succinea or Physa from Europe to the lakes of Central Africa." It ought to be remembered, however, that eggs of some kinds, thus exposed to the atmosphere until dry, would become very firmly attached and so remain even when again moistened, ${ }^{3}$ so that they would not be easily dislodged in a new locality; but, as many birds probably travel during gales at the rate of thirty-five miles an hour or much faster, ${ }^{4}$ eggs might certainly be carried before drying to considerable distances, and then when again dipped in water would soon become detached. Many kinds attach their eggs to aquatic plants, fragments of which, we shall see, are likely to be carried by birds. Something may possibly have been done by insects, for Mr. Standen informs me that he once saw, in the Hollinwood canal, an egg-capsule of the river-limpet (Ancylus fuviatilis) attached to one of the wing-cases of an Acilius, a strong flying water-beetle. Some eggs, it

1 “Island Life," I 880, p. 76 ; ed. 2, p. 79 ; R. Tate, "Land and Fresh-water Mollusks," I866, p. I88; H. H. Godwin-Austen, "Field," lxvi. (1885), 499.

"See "Zoologist," (3), i. (1877), 260-I.

3 This happened, at least, to eggs of Limnca auricularia, which I exposed on a tin tray and on frarments of water-weeds.

4 "Origin," p. 326. 
should be noted, from the localities in which they are deposited or the nature of the objects to which they are usually attached, are not at all likely to be dispersed by animals, and it will be remembered that some molluses are viviparous. The fry, probably, are transported more frequently than ova. Those Unionidge whose larvæ are parasitic for a time upon fishes are eminently liable to wide dispersal, at least, through waters in any way communicating with their habitats. The larvæ of Anodonta sivim by the flapping of the valves of their shells, trailing at the same time a long byssal filament, and weaving themselves together in masses which spread out like a net. Little fishes, stirring up the masses, carry many larvæ away, the creatures managing to effect a hold-chiefly to the fins-by means of the toothed edges of their shells. They then become encysted, and are nourished, it is stated, by the exudations of the fish. Ultimately, on the splitting of the cyst, they drop out and fall to the bottom. In aquaria, Anodonte which have retained their brood in long quiescence, have been observed to let it out immediately on the introduction of fishes. The larvæ of Unio, differing in certain respects, are said to be inhaled by fishes, and are usually found attached to the gills. ${ }^{1}$ Whether these fry are likely to be carried

1 E. Ray Lankester, art. Mollusca, "Encyclopædia Britannica," ed. 9, xvi. (1883), 694 ; and see also Dr. Schierholtz's memoir as to the development of the Unionida, Imperial Academy of Science, Vienna, I888, my knowledge of which is derived solely from a leaflet printed by Mr. Standen, in explanation of specimens illustrating the life history of Anodonta, shown by him at one of the Manchester Microscopical Society's soirees. 
from one piece of water to another by birds, etc., I am unable to say, for I have not seen it stated that they are able to withstand exposure to the atmosphere. The same remark applies to the free-roving pelagic larvæ of Dreissena. The just-hatched young of certain univalves, we know, are well suited for such transportal, for they cling firmly, and can live out of water for hours. On this head we have Mr. Darwin's celebrated and often quoted experiment with a duck's feet in an aquarium :

"I suspended the feet of a duck in an aquarium, where many ova of fresh-water shells ${ }^{1}$ were hatching; and I found that numbers of the extremely minute and just-hatched shells crawled on the feet, and clung to them so firmly that when taken out of the water they could not be jarred off, though at a somewhat more advanced age they would voluntarily drop off. These just-hatched molluscs, though aquatic in their nature, survived on the duck's feet, in damp air, from twelve to twenty hours; and in this length of time a duck or heron might fly at least six or seven hundred miles and if blown across the sea to an oceanic island, or to any other distant point, would be sure to alight on a pool or rivulet." "

Unfortunately, however, I cannot find, after inquiring of a number of experienced ornithologists and sportsmen, that the creatures have ever been seen adhering to birds shot on the wing; Mr. Dresser, for instance, though he has shot thousands of aquatic birds in

1 Univalves, as Mr. F. Darwin informs me.

" Origin," p. $3+5$. 
various countries, has never seen shells attached, and Mr. O. V. Aplin, the Rev. J. C. Atkinson, Mr. Abel Chapman, Mr. Cordeaux, the Rev. H. A. Macpherson, Mr. T. H. Nelson, and Mr. Howard Saunders have also replied in the negative to my inquiries on the point. But from general considerations, and especially in view of Mr. Darwin's experiment, it can hardly be doubted but that very young molluscs do thus adhere somewhat frequently, and perhaps the absence of observations made in the field is not surprising, for, as $\mathrm{Mr}$. Layard remarks to me, the creatures are hardly likely to be noticed unless specially looked for, and this I suppose is very rarely done; indeed $\mathrm{Mr}$. Aplin, replying that he had never seen young molluscs on the feet of water-birds, carefully added that he had never looked for them. Mr. F. Norgate, it is interesting to find, once noticed a small grey leech clinging to the plumage of a mallard shot by him. Mr. Macpherson remarks that widgeon, etc., sitting all day long half awake in the wet sedge, are very likely to carry shells on their feet or feathers when they fly at night to their feeding-grounds, and as Dr. Kobelt ${ }^{1}$ has suggested, the creatures will have a good chance of adhering also to the feet and legs of herons and other birds which often stand motionless in water for hours. Even adult shells of the smaller kinds may often attach themselves, but these, I suppose, in most cases, are soon shaken off. Mammalia frequenting fresh water, otters for instance, scem likely to

"IV. Kobelt, "Fauna der Nassauischen Mollusken," I87r, P. I 4 . 
transport molluscs adhering to their coats, and many other creatures which occasionally journey over land have probably helped in the work; but their influence, that of mammalia at least, is doubtless chiefly local, and must always be confined to a given tract of land. Birds, it will be remembered, commonly fly across arms of the sea and are not unfrequently blown by gales over wide stretches of ocean; flying water-insects, also, which may sometimes carry fry as well as ova, are occasionally blown to great distances.

It scems probable that young and small shells may sometimes be transported along with the small water-plants which occasionally adhere to birds. Mr. Darwin, in removing a little duckweed from one aquarium to another, unintentionally stocked the one with fresh-water shells from the other, and he twice saw duckweed adhering to the backs of ducks which had suddenly emerged from a pond covered with these little plants.' It would be interesting to ascertain whether small shells, and the fry of larger kinds, are often found amongst such plants. A small tin cartridge-box full of gibbous duckweed (Lemna gibba) skimmed from the surface of one of the streams by the Lea in September, contained a number of little aquatic animals, shrimps, leeches, a beetle, etc., but no shells. A similar quantity of lesser duckweed (Lemna minor), however, carefully picked (in August) from the surface of a pond near Louth, yielded no less than forty-two shells, apparently alive: four of Spharium corneum and thirty-

$$
\text { ' "Origin," pp. 344-5. }
$$

\section{E 2}


one of Limnea peregra, all young, together with seven full-grown specimens of the little nautilus coil-shell (Planorbis nautilens). Mr. Cordeaux once noticed minute molluscs among duckweed within the bill of a wild duck shot by him, the bird having risen, no doubt, in the very act of feeding. Confervoid vegetation, also, seems likely to cling to birds, and Mr. Bridgman mentions having found masses of it literally teeming with Planorbis nitidus, in company with a species of Valvata; after two or three weeks, however, the creatures, having probably come to maturity, disappeared. ' It must not be forgotten that parts of larger water-plants, to which fry or ova may possibly be adhering, may occasionally be carried by birds. The moor-hen, for instance, might casily carry parts of plants in which its feet had become entangled, and Mr. Norgate suggests that herons, etc, are likely to carry them when flying off with struggling cels hastily snatched from the mud and weeds. Mr. Standen mentions the shooting of suddenlyflushed snipe, moor-hens, and wild ducks with weed clinging to their feet, and he once flushed a heron which rose with so large a quantity dangling from one of its legs that its flight was considerably impeded. Transportal of fragments of water-plants in this manner probably happens quite commonly, for many kinds, as Mr. Clement Reid $^{2}$ has recently remarked, have extremely brittle stems, and finely divided or thin leaves which on removal from the water collapse and cling

1 W. K. Bridgman, "Zoologist," ix. (1851), p. 3303.

2 "Trans. Norfolk and Norwich Nat.Soc.," v. (1892), pp. 278,',283-4 
closely to any object they may touch. The plants found in ponds of extreme isolation, according to this observer, are not usually species with succulent fruits, such as are known to be habitually eaten by birds, and species with burrs or hooked fruits are by no means abundant; most of them, in fact, have the fruits dryseeded and thin shelled, which, if eaten at all, would probably be digested and have their vitality destroyed; even water-thyme (Elodea canadensis), which is fruitless in this country, sometimes occurs in isolated dew-ponds. It seems probable, therefore, that most of these plants are "transported in fragments, which breaking, cling to the feet of waders, to be washed off when the bird flies to the next pond," and this, it is added, "will also account for the constant occurrence of the Limnæids, which both adhere to the stems and attach their eggs to them." Large numbers of young or small molluscs might be transported together in this way. On one occasion, on examining a small quantity of horned pond weed (Zannichellia), which had been taken home (after having been well shaken to get rid of snails) from an isolated pond on the South Downs, Mr. Reid found, adhering to it, fully 150 specimens of Limnea and Planorbis, mostly very minute, and several clusters of eggs! Some molluscs, it is true, live much in or on the mud, and do not attach their eggs to plants, or are viviparous, but most of these, I believe, at some period of their existence, or during certain parts of the ycar, are to be met with among the leaves and stems of the water-weeds. 
The beaks and fect of birds sometimes have carth adhering to them," and this in the case of those frequenting the muddy edges of ponds and streams may sometimes have young molluscs, and even fullgrown Pisidia and other small shells sticking to or embedded in it. A top-knot pigeon (Lopholaimus antaretica), shot by Mr. Musson in New South Wales, had a small ball of earth surrounding each leg, just clear of the ground, "no doubt accumulated as the bird wandered about on the muddy margin of some waterhole," " and Mr. Darwin once received a woodcock's leg from a friend with a little cake of carth, weighing nine grains, attached to the shank. ${ }^{3}$ Mr. Hardy and Mr. Standen both call to mind instances of snipe shot with clayey mud clinging to their feet and legs, in sufficient quantity, they think, for the retention of Pisidia, etc., and no doubt many observations of this kind might be got together. As is well known, seeds of plants have been found in the earth thus adhering, but I have not heard that shells have been discovered in it. It is worth mentioning, perhaps, that Mr. Darwin once found a pebble, as large as the seed of a vetch, and, therefore, as large as some full-grown Pisidia, in a little earth removed from the foot of a partridge. ${ }^{4}$

1 "Origin," p. 345 .

2 C. T. Musson, "Proc. Lin. Soc. N.S.W.," (2), iv. (1889), 388 ; one of the legs of the pigeon, and the accompanying ball of earth, weighing nine grains, were exhibited at the Society's mecting.

" "Origin," p. .228 .

4 "Origin," p. 328 . 
The probable dispersal of bivalves while holding on by closure of their shells to the toes, etc., of birds, amphibia, aquatic insects, etc., remains to be dealt with in the next chapter, and it will be seen that animals have been secured, in a few cases, in the very act of carrying the creatures over land. Dealing with univalves in chapter iv., I shall have to suggest a somewhat analogous mode of dispersal of operculata, namely, by closure of the operculum so as to hold on to insects, etc. ; and a few cases of the clinging of inoperculate univalves, by adhesion, to amphibia, insects, and the like, will be added, but these latter might almost have been included above, for young shells will have been oftener thus carried than full-grown ones. 


\section{CHAPTER III.}

TRANSPLANTATION OF BIVALVES.

BIVALves frequentiy lie with their shells slightly apart, and, as is well known, quickly close upon objects which happen to be introduced between the valves. Birds, wading about at the muddy and sandy margins of ponds or rivers, and aquatic or amphibious animals of various kinds sometimes accidentally inscrt their toes, and the mollusc, in such a case, closing quickly and often holding on for a considerable time, is liable, if not too heavy, to be carried away and to be set down, perhaps, in a new home, possibly at a great distance from its original habitat. Accidents of this kind, there is reason to suppose, happen much more frequently than might at first seem probable, for numerous instances have been recorded, and probably not more than one in a thousand comes under the notice of an observer, and the number recorded must be small as compared with the number actually observed.

A few facts serving in a general way to illustrats the liability of bivalves to be carried away upon objects chancing to come between the valves are perhaps worth giving. Rurdl folk who make cream-skimmers 
of the valves of the great pond-mussels (Anodonta cygnea) procure them, according to Mr. Jeffreys, by means of a long pointed stick, which is inserted between the gaping shells. The animal closes upon the stick and allows itself to be drawn up out of the water. ${ }^{1}$ Pearlmussels (Unio margaritifer), as Professor Tate relates, are dragged to shore by country boys in a similar manner upon long slender rods. ${ }^{2}$ I recently experimented by the Lea upon a number of Anodonte and Uniones, most of which, I found, allowed themselves to be drawn from the mud and out of the water upon inserted grassstems. A few fell almost immediately, but, of six which were carried away suspended upon the grasses, four (two of each genus) were still holding on when I reached home after the space of an hour and a half, including about ten minutes in a train; these were then suspended from a shelf, and one Anodonta (two and a half inches long) still retained its hold fifty-one hours after it had been taken from its habitat, and on being placed in water it extended its foot and ultimately became detached. The Rev. E. A. Woodruffe-Peacock tells me that he used to catch hundreds of mussels in his father's fish-pond in this way, drawing them to land upon stiff straws, twigs, or fine wire, and the fact that the creatures will allow themselves to be thus taken seems to have been long known, for Sir Robert Redding, in a letter dated in 1688 , mentioned that the poor people in

\section{1 "British Conchology," i. (1862), lxviii.}

"Tate, "Land and Fresh-water Mollusks," I866, p. 27, and see also "Science Cossip" for 1870, pp. 265-6. 
the North of Ireland fished for pearl-mussels some with their toes, some with wooden tongs; and "some by putting a sharpened stick into the opening of the shell take them up." " The Rcv.J. W. Horslcy, while trolling with a dead fish for pike, once brought up a large Unio which had closed upon the bait. A friend of Mr. IV. D. Crick's, as the latter told Mr. Darwin, often, while fishing in rapid streams, caught small Uniones upon the hook, and Mr. F. Darwin, when fishing off the shores of North Wales, scveral times caught mussels in a similar way." According to Mr. D. Pidgeon, heartcockles (Isocardia cor) have been known to close upon the shanks of accidentally intrusive fish-hooks with such force as to crush the edges of their shells against the stecl wire, and they permit themselves to be drawn in with the line to which the hook is attached, many having been thus taken by the long-line fishermen on the Irish coast. ${ }^{3}$ Marine bivalves, such as cockles, mussels, etc., have several times becn found clinging to the toes or bills of birds of various kinds, ${ }^{4}$ and the

1 "Philosophical Transactions," xvii. (1693), 660.

2 Darwin, "Nature," xxv. (1882), 529-30.

3 D. Pidgeon, "Nature," xxv. (I 882), 584.

4 Instances of the capture by marine bivalves of fish, mice, a rat, foxes, etc., have also been recorded: see as to fish, "Popular Science Monthly," xvii. (I880), III ; oyster and mouse, "Science Gossip," I 875, p.68 ; oyster and mouse, "Daily Telegraph," quoted in the "Field," lxvi. (1885), 499 ; oysters and mice, several cases, "Bell's Weekly Messenger," etc., quoted in Loudon's " Mag. Nat. Hist.," ii. (1829), I50; oyster and young rat, caught by the tail, "Life Lore," ii. (1890), 216 ; mussel and fox, caught by the tongue, Loudon's "Mag. Nat. Hist.," viii. (1835), 227-8; oyster and fox, 
observed instances, of which I am tempted to give notes, are perhaps suggestive; but birds thus entrapped - whether by marine or fresh-water bivalves-must often be unable to carry away the molluscs to any considerable distance, especially when the creatures happen to close upon their bills. A dunlin with a small cockle about the size of a hazel-nut clinging to its bill was once found, near the estuary of the Moy, by Mr. Robert Warren. It was seen to be making frantic efforts to get rid of the shell, rising two or three yards into the air and falling again, and after shaking its head until exhausted, it lay with outstretched wings panting on the sands. ${ }^{1}$ A bird of the same kind with a cockle similarly attached, which had been picked up dead on the Yorkshire coast, was forwarded to the offices of the Field, in I884, by Sir R. Payne-Gallwey." Another dunlin with a cockle upon its bill, which got up from the observer's feet and flew heavily away, was shot in IS9I. A tern with a cockle fixed on the upper mandible was once shot, on the sands at Morecambe Bay, by Mr. Hancock, who has given an account, also, of the capture, on Fenham Flats, of a peewit in a similar plight, having a cockle firmly grasping its bill. ${ }^{4} \mathrm{~A}$

caught by the tongue, "Daily News," October 5, 1892 ; racoons and other animals are also said to have been entrapped by shell-fish.

'R. Warren, "Field," lxiii. ( $188_{4}$ ), 447.

2 "Field," lxiii. (1884), 385 .

3 "Scottish Naturalist," 1891 , p. 94.

"Hancock's "Catalogrue of the Birds of Northumberland and Durham," "Nat. Hist. 'Trans. of Northumberland and Durham," vi. $(187+), 1+2$. 
sandpiper which had a large cockle upon one of its claws and was unable to fly was seen by Mr. D. McNabb, in I889, on the coast of Queensland, ${ }^{1}$ and a curlew sandpiper with a cockle hanging to one of its toes was shot, a few years ago, as Mr.J. H. Gurney tells me, by Mr. G. Hoare, at Cley, in Norfolk; a snipe with a large cockle attached in the same way is said to have been shot on the wing in or about 1866,2 and the shooting of a sanderling with a cockle thus attached was recorded in I $872 .{ }^{3}$ Mr. Gurney tells me that a tern, caught by the foot by a mussel, was found some twenty-five years ago on the Hunstanton beach in the Wash by Mr. F. Cresswell, and that a grey crow with a mussel upon its bill was caught by $\mathrm{Mr}$. C. Springall, in I888, on the beach at Brancaster. An account, as related by an old hunter, of the finding of a shoveller duck with an otter's-shell (Lutraria) upon its bill was given by Mr. J. K. Lord in 1865.4 Mr. Buckland (on the authority of Mr. F. Hill, of Helston) has described the capture of a rail by an oyster; the specimens, of which a photograph was obtained, had been mounted in a case. ${ }^{5}$ Mr. Norgate tells me that he saw a stuffed water-rail, with its bill in an oyster-shell, at the National Fisheries Exhibition, at Norwich, in I88 I.

' D. McNabb, "Nature," xlii. (I890), 4 I 5.

" J. B., "Science Gossip," I 866, p. 63.

${ }^{3}$ H. R. Leach, "Zoologist," (2), vii. (1872), 33 I .

4 J. K. Lord, "Science Gossip," I 865, p. 79.

5 "Popular Science Monthly," xvii. (1880), III.4, copied from "Land and Water." 
The closure of an oyster upon one of the toes of a golden plover was recorded in the Field, in I889, ${ }^{1}$ and the taking of a cormorant with an oyster upon its bill was reported, in 1892, in the Daily News." Many other similar records, no doubt, might be found; but we must pass on to the consideration of facts which have a more direct bearing upon the subject in hand.

\section{INSECTS.}

From the number of observations which have been made, it seems that small fresh-water bivalves, such as Spharium and Pisidium, frequently attach themselves to aquatic insects.

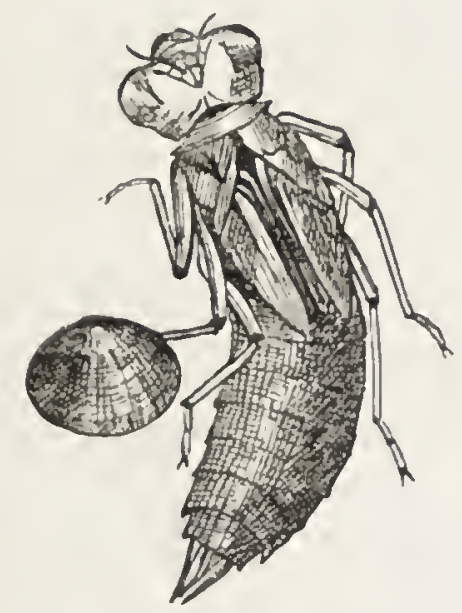

FIG. I.

Spharium cornewm upon the leg of a Dragon-fly-iarva : taken at Twenty Pits, near Manchester, and now in the Manchester Museum.

The larva of a dragon-fly with a shell of Spheerium corneum clinging to one of its legs was once caught at Twenty Pits, near Manchester, and the specimen preserved with the shell attached (Fig. I) is

\footnotetext{
1 "Field," lxxiii. (1889), 308.

"Daily News," October 4, I89z.
} 
now to be seen in the Manchestcr Muscum, where it was deposited by Mr. Hardy. This occurrence, howcver, is not of much importance for us, for I am not aware that dragon-fly larve ever journcy overland.

The clinging of bivalves to flying water.bugs and -bectles is of more intcrest. Five individuals, at least, of the water-scorpion ( $N e p a$ ), a large flying bug, have becn caught with shells attached. A specimen with a small Spharium corneum on one of its legs, obtained in I 879 from Mere Mere, Cheshirc, by Mr. J. Walken, is now exhibited in the Manchcster Muscum, where, also, is another specimen (prescrved in spirit) having attached to it a much larger shell of the same specics; two others, collected by Mr. Hardy in ISS9, each carrying a shell of Pisidium fontinale upon a leg of the hind pair, are also possessed by the Museum. (Fig. 2.) A fifth

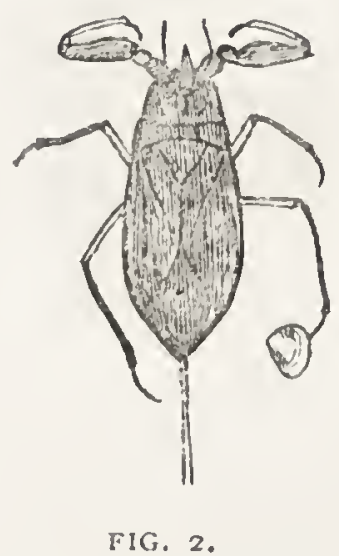
Pisidium fontinale upon the leg of a water-scorpion (Nepa); now in the Manchester
Iuseam.

instance has becn observed by $\mathrm{Mr}$. Standen, who caught a specimen with $P$. fontinale attached, in a pond near Birch Hall, Manchester, on 16th May, I89o.

A number of watcr-bugs (Notonecta) with "small 
mollusks attached to their legs," were exhibited by Mr. Whitelegge at a mecting of the Linnean Society of New South Wales in I 885, and I hear from Mr. C. Hedley that in the vicinity of Sydney, Mr. Whitelegge has frequently noticed hemipterous insects, both Notonecta and Corixa, laden with bivalves: three specimens of Pisidium etheridgei have been seen attached to one insect, one on each fore-leg and one on the snout.

Quite a number of instances of the clinging of these molluscs to water-beetles can be giren. As stated by Mr. Darwin in a letter published in "Nature" in IS82, a specimen of the "great water-beetle," Dytiscus marginalis, with a shell of Cyclas cornea $[=$ Spharium corneum] clinging to one of its legs, was caught by $\mathrm{Mr}$. W. D. Crick, of Northampton, on I Sth February of that year:-

"The shell was' 45 of an inch from end to end, '3 in depth, and weighed (as Mr. Crick informs me) ·39 grams, or six grains. The valves clipped only the extremity of the tarsus for a length of ' $I$ of an inch. Nevertheless, the shell did not drop off, on the bectle when caught shaking its leg violently. The specimen was brought home in a handkerchief, and placed after about three hours in water; and the shell remained attached from February 18 th to $23 \mathrm{rd}$, when it dropped off, being still alive, and so remained for about a fortnight while in my possession." :

1 "Proc. Lin. Soc., N.S.IW.," x. (1886), 760.

2Darwin, "Nature," xxv. (1882), 529-30; and see also "Life and Letters," iii. (1888), 252. 
Other specimens of the same kind of water-beetle with Sphorium corneum attached have since been obtained: Mr. C. Oldham found one, with a shell of good size firmly clasping the extremity of one of the front legs, in a pond at Woodford, Essex, in September, I 886 ; and I had the good fortune to catch a specimen

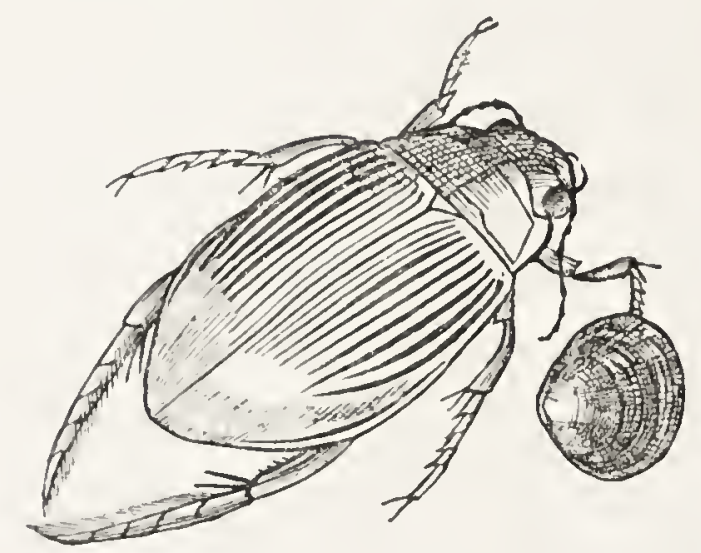

FIG. 3 .

Sphcerium cornewn upon the leg of a water-beetle (Dytiscus); taken at West Barkwith, Lincolnshire, and now in the Manchester Museum.

with a shell upon the right front leg in a pond at West Barkwith, Lincolnshire, in August, I888 (Fig. 3).' Mr. W. H. Heathcote found another specimen with a shell similarly attached at Farington, Lancashire, in I889; and a further case, in which a small shell was attached to one of the hind legs of the beetle, was observed by Mr. Standen, in June, I890, in a pond at Birch, near Manchester.

Some large water-beetles, kept by Mr. Norgate in an aquarium, Mr. Darwin states, frequently had one foot caught by a small fresh-water bivalve ( $S$. corneum? ?

1 "Juurn. of Conch," vi. (1888), 363; "Proc. Ent. Soc., Lond," I $888, \mathrm{p} \times x \times v$.

: "Nature," xxv. (I882), 529-30. 
A specimen of Dytiscus marginalis with a shell of Spharium lacustre clinging to one of the front legs was caught by Mr. Standen, in a pond at Gorton, in I 890. The shell had been slightly broken, probably from having been dashed against some object by the insect, but, being still alive, it held on tightly. A beetle belonging to the allied genus Acilius with a shell of Pisidium fontinale on one of the legs of the second pair has been presented to the Manchester Museum by Mr. Hardy,' and I hear from Sydney that two water-beetles with Pisidia attached were obtained by Mr. Whitelegge (now of the Australian Museum) when collecting, years ago, in Lancashire; in one of the cases two shells were clinging to the same insect, one on each side.

Two or three instances of the clinging of bivalves to the antennæ of water-beetles have been observed, ${ }^{3}$ and Mr. A. J. Jenkins tells me that in a large bell-glass, which he used as a sort of aquarium, a Pisidium on one occasion fastened its valves tightly upon one of the maxillipedes of a shrimp.

Before coming to any conclusion as to whether waterbeetles, -bugs, etc., have much affected the ranges of bivalve-molluscs and have helped in any perceptible degree to stock newly formed and isolated ponds with

1 This and the other specimens here stated to have been presented to the Manchester Museum were obligingly sent to me in London for examination; two of them, I regret to say, were damaged in the post.

2 A case of this kind once came under the observation of $\mathrm{Mr}$. Hardy; another is recorded in "Science Gossip," I873. p. 190, and see also "Nature:" xxv. (1882), 529-30. 
these animals, it scems necessary to inquirc as to thcir flying habits, and I have tried, but without much success, to ascertain how often they take wing, whether they are in the habit of making long flights, etc. Canon Fowler, of whom I inquired, is inclined to think that Dytisci, as a rule, do not take to flight unless their pools are drying up, his impression being that they simply fly when driven by necessity, and then make for near water; and if such be the case it is obvious, of course, that the facts concerning them just referred to have but little significance. But on the other hand, Mr. Darwin" ventured to observe that "the species of Dytiscus often fly at night," and indeed he had several times heard of their having dashed down upon glass cucumber-frames, mistaking the glittering surface for water, and Mr. Norgate informs me that he has actually seen the insects upon the glass of such frames. A specimen of $D$. marginalis once flew into a shop in Hull, and from the nature of the locality, it is probable that it had travelled some distance. ${ }^{2} \mathrm{Mr}$. Standen states that he has several times caught the creatures on the wing when out moth-hunting after dusk in the evening, ${ }^{3}$ and $\mathrm{Mr}$. Musson tells me that he has taken large water-beetles at the electric light in the main strect of Tamworth, New South Wales. It is unfortunate that more definite information is not forthcoming, but I believe we may conclude that these beetles journey from pond to pond

1 “Nature," xxv. (1882), 529-30.

"E. Lamplough, "Science Gossip," xxiii. (1887), 19.

3 R. Standen, "N Nat. Hist. Notes," iii. (1883), 39. 
in the evening or at night somewhat frcquently, and it is perhaps worth mentioning that at the Linnean Society in I852, John Curtis, the distinguished entomologist, expressed the opinion that the larger aquatic insects-especially the Dytiscidæ-might without doubt be the means of conveying fish-spawn from one piece of water to another, ${ }^{1}$ and $\mathrm{Mr}$. Wallace, in like manner, discussing the means of dispersal of fishes, observes that water-beetles "flying from one pond to another" may occasionally carry eggs." No doubt, as Mr. Darwin has remarked, the creatures generally alight on any pool of water they may see, for there is no reason to suppose, as far as I lnow, that they are in the habit of "homing" or returning to the same pool from time to time. But another difficulty has to be met. At the Entomological Society in I888, when I showed the West Barkwith specimen of $D$. marginalis with the attached shell of Spharium corneum, and ventured to suggest that occurrences of the kind indicated were probably of significance when viewed in connection with the distribution of bivalves, Dr. David Sharp, the president, objected that the weight of the mollusc would in all probability prevent or greatly impede the beetle's flight, and this objection, no doubt, will have suggested itself to many. Mr. Darwin, however, has expressed the opinion that six grains (the weight of an individual of $S$. corneum of average size) would not prevent so powerful

'See J. Hogg, "Trans. Tyneside Nat. Field Club," iii. (1854S), 75 .

"Wallace, "Geographical Distribution," i. (1876), 29. 
an insect as a Dytiscus from taking flight, adding that in any case the beetle could carry smaller shells. ${ }^{1}$ Mr. Oldham induced his Woodford specimen of $D$. marginalis, which was encumbered with a good-sized shell of S.corneum, to fly about in a room, and it did not seem to be greatly impeded; and what is still more important for us, individuals of this species of beetle carrying S. corneum have actually been caught on the wing on two occasions, the insect, in one case, having two shells clinging to it! Both captures were made by Mr. Standen while pursuing nocturnal Lepidoptera: the first specimen, netted in 1883 with a full-grown shell clinging to one of its legs, was slowly flying along in Mill Lane, Goosnargh, about five hundred yards from the nearest pond, but it might possibly have come from a small ditch about one hundred yards distant; the second capture was made at Moor Side, Swinton, near Manchester, in I888, when Mr. Standen had the good fortune to take, on the wing, a specimen which was carrying two shells, one being of good size and the other small; the nearest pond, he thinks, was about one hundred and fifty yards distant. These cases are obviously of extreme interest and value, for they not only corroborate Mr. Oldham's observation and render it quite clear that $D$. marginalis is strong

1 "Nature," xxv. (1882), 529-30.

2 This occurrence was briefly referred to by Mr. Standen in "Nat. Hist. Notes," iii. (1883), 39, and in "Science Gossip," xxi. ( 1885 ), 281 , and was quoted by me in the "Naturalists' World," iii. (1886), 6I . 
enough to carry shells, at least as large as S. corneum, but they also furnish the much required proof of actual overland transportal. No doubt the water-bugs above mentioned are able to carry Pisidia of the size of $P$. fontinale, as well as young Sphceria, but I have not succeeded in obtaining any definite information respecting their flying habits. Nepa is certainly a powerful insect, and probably it frequently takes wing. Some of our common "water-boatmen" (Notonecta, etc.) are probably even stronger, and I have once or twice seen them alight upon the surface of ponds in the sunshine, fold their wings, and disappear into the water.

From the facts now given, I think it may be safely concluded that the local distribution of the smaller bivalves has been influenced in a marked degree by aquatic insects; many isolated cattle-ponds, we may feel sure, have been stocked with these molluscs by chance visits from flying water-beetles and the like, and as these occasionally stray out to sea or are blown to great distances by gales, the facts have possibly a wider significance: Mr. Darwin records that a Colymbetes, a water-beetle belonging to the Dytiscidx, once flew on board the Beagle when forty-five miles distant from the nearest land.'

\section{Amphibia.}

Newts, frogs, toads, etc., it seems, often have their toes caught by small bivalves: quite a number of instances can be given; a frog, in one case, had two

$$
1 \text { "Origin," p. } 345 .
$$


shells upon the toes of the same foot, two newts have been seen each carrying four shells, and toads have been dredged with as many as six shells upon their toes.

The first record, as far as I have ascertained, of freshwater bivalves clinging by closure to other creatures is contained in Knapp's "Journal of a Naturalist," published in 1829 , and has reference to the "common newt (lacertus aquaticus)":-

"I have seen the boys in the spring of the year draw it up by their fishing lines, a very extraordinary figure, having a small shell-fish (tellina cornea) [= Spharium corneum] attached to one or all of its feet; the toes of the newt having been accidentally introduced into the gaping shell, in its progress on the mud at the bottom of the pool, or designedly put in for the purpose of seizure, when the animal inhabitant closed the valves and entrapped the toes. But from whatever cause these shells became fixed, when the animal is drawn up hanging and wriggling with its toes fettered all round, it affords a very unusual and strange appearance."

In $1885 \mathrm{Mr}$. R. W. Goulding recorded the finding of a newt with a Cyclas (probably S. corneum) upon one of its feet in a pond near Louth, Lincolnshire, ${ }^{2}$ and $\mathrm{Mr}$. Heathcotc on two occasions in I889 found shells of $S$.

1 J. L. Knapp, "Journal of a Naturalist," I 829, p. 305 ; Mr. F. J. Rowbotham called attention to this passage in "Nature," $\mathrm{xxv}$. (1882), 605.

2 R.W. Goulding, "Science Gossip," xxi. (1 585 ), 238-9, and see also p. 249. 
corneum attached to the toes of newts at Farington, Lancashire. The late Mr. W. Jeffery told me that ever since he was a boy dabbling with aquaria he had occasionally met with this bivalve clinging to newts; the same has been frequently observed by Mr. L. E. Adams in ponds in the South of England, and Mr. Hardy, during his long experience as a collector, has

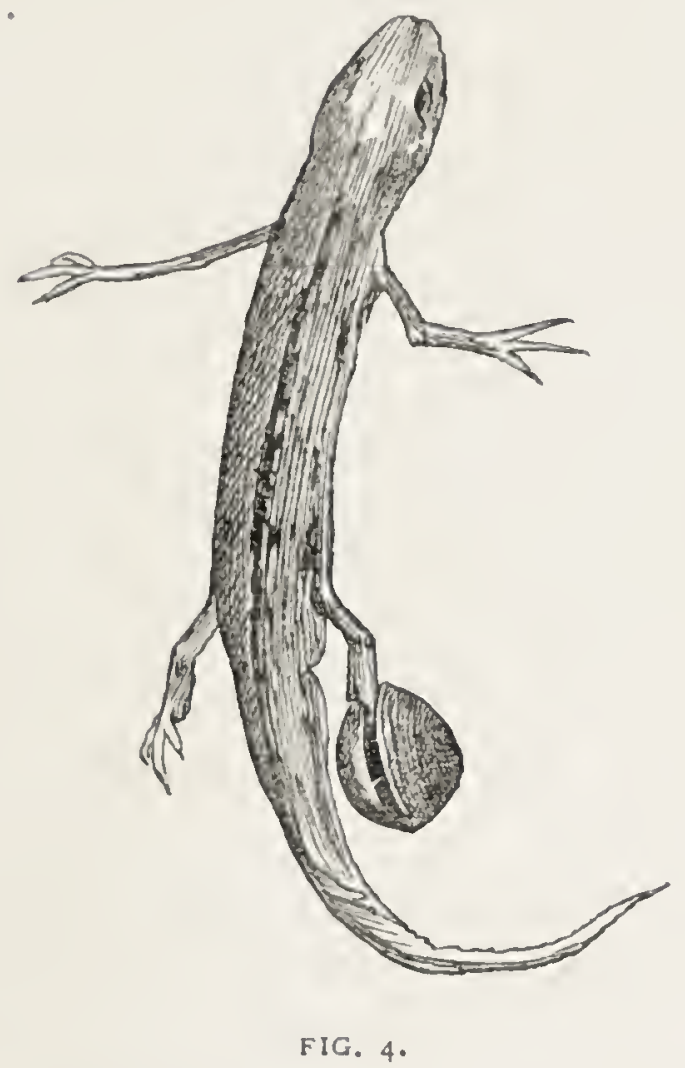

Splucrium comeum upon the foot of a newt. Preserved in the Manchester Museum.

observed many instances (Fig. 4), as also has Mr. Standen, who informed me in I 890 that for many years he had not missed taking either smooth or great warty newts (Molge vulgaris or $M$. cristata) with shells of this species upon their feet. In I 890 , in ponds in the neighbourhood of Manchester, he met with four instances, three with $M$. vulgaris and one with $M$. cristata: in one case, 
in a pond at Birch, a newt had four shells clinging to it, two on one hind foot, and one on each of the fore fect. A specimen with four shells attached had been previously taken in $\mathrm{I} 883$ in a ditch at Goosnargh, the creature being so much encumbered that it stumbled along with difficulty.' The entrapped toes, according to this naturalist, are frequently much swollen, which seems to show that the shells often remain attached for a considerable time. In ISS I, Mr. Norgate informed Mr. Darwin that the newts in his aquarium frequently had one foot caught by a small fresh-water bivalve ( $S$. conneum?) ; this, he said, made them swim about in a very restless manner, both day and night, for several days, until the toe to which the shell was fixed was completely severed. ${ }^{2}$ Mr. Jenkins states that he also has seen newts caught in this way in aquaria. The taking of a newt, the lower jaw of which was firmly clasped by the valves of a Pisidium, was recorded by Mr. Heynemann in $1870 .^{3}$

Mr. J. T. Riches, in a note published in 1877 , mentioned that he once received a living frog (which had been found upon a bank by the side of a canal) with a fullsized shell of Cyclas cornea [ $=S$. corneum] upon one of its toes. The shell remained attached until, after two days, it was removed by the observer. ${ }^{4}$ A recently killed

'R. Standen, "Science Gossip," xxi. (1885), 28 I .

2Darwin, "Nature," xxv. (I882), 529-30.

3 D. F. Heynemann, "Bericht über die Senckenbergische naturforschende Gesellschaft," I870, p. I 30.

‘ J. T. Riches, "Science Gossip," xiii. (I877), 93. 
frog with a shell of the same species attached to the outer toe of one of its hind legs was found by Mr. Crick, in the spring of 1882 , by the side of the pond, presumably near Northampton, in which, a fortnight before, he had taken the water-beetle and shell referred to above. The frog's leg was cut off, and the shell continued to cling for two days, during which it was kept in water, but, on being left in the air, the leg soon became shrivelled, and the shell, being still alive, detached itself. ${ }^{1}$ Mr. Goulding, in I884, found a frog with the shell of a Cyclas (probably S. corncum) upon one of its toes in a pond near Louth. ${ }^{2}$ Mr. Hudson tells me that he once saw one, swimming in a pond at Redcar, with two shells (which were found to be those of S. corneum) upon the toes of its left hind foot; and another, having an immature Sphcerinm upon one of its toes, was seen by the Rev. S. Spencer Pearce, in I885, at low water on the south bank of the Thames between Putney and Hammersmith Bridges. Mr. Standen, in a letter published in 1885 , mentioned that he had often found these amphibians with shells of $S$. cormeum attached, ${ }^{3}$ and he has favoured me with a note of a case observed subsequently in a lake at Drinkwater Park, near Prestwich. Mr. Hardy in the course of his collecting has observed

'See "Nature," xxv. (I 882), 529-30.

2 R. IV. Goulding, "Science Gossip," xxi. (1885), 238-9, and see also p. 249 ; a statement by me, in the "Naturalists' World," iii. (1886), 61, that a newt and a frog had been noticed in the neighbourhood of Louth each with a Sphcrium attached is based upon Mr. Goulding's observations.

3 R. Standen, "Science Gossip," xxi. (1885), 28 I. 
several similar instances. While writing (March) I received a living frog from Lincolnshire (through the kindness of Mr. Davy) together with a specimen of S. corneum, which when packed up was clinging to one of the toes, but had become detached during the journey: the specimens had been obtained by $\mathrm{Mr}$. Woodthorpe, one of the members of the Naturalists' Society at Alford, from a batch of frogs which were spawning in a ditch in that parish; five or six other frogs similarly encumbered had been seen in the ditch, all the shells being attached to toes of the hind legs.

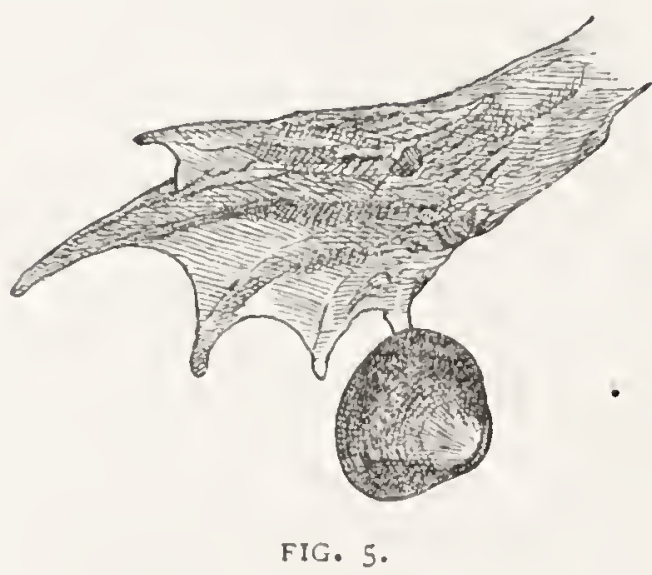

Sphcrimm comeum upon the toe of a Toad; taken from a pond on Hampstead Heath, and now in the British Museum.

The Rev. R. C. Douglas, in I 85 , recorded the finding of a toad, in June, crouching on the marshy edge of a fish-pond, with the middle toe of one of its hind feet held between the valves of a "mollusk about half an inch in diameter, Cyclas cornea, I think;" locomotion on the part of the toad, he says, was effectually impeded. ${ }^{1}$ Mr. J. Peers, who wrote from Warington in I 865, while dredging in April in a pond in which both toads and

1 R. C. Douglas, "Zoologist," ix. (1851), 3210. 
Cyclas cornea abounded, observed a number of the shells clinging "with the greatest tenacity" to the toads, some of which had no less than three shells on each of the hind feet, while instances in which the toes were entirely free were very rare. None of the shells were attached to the fore feet.' Mr. Standen, according to his published note of I 885 , has also seen the toes of toads firmly grasped by these shells, ${ }^{2}$ and in April, I892, when a number of toads were spawning in the "leg-of-mutton" pond on Hampstead Heath, I fished out an individual with a fine shell of the same kind on a toe of one of the hind legs (Fig. 5).

These cases, it will be seen, furnish no actual evidence of dispersal, for the amphibians, I believe, were all caught in water or in its immediate vicinity. It is obvious, of course, that such animals can never carry shells to great distances, and if we are to form an opinion as to the extent to which they have affected local distribution, we ought to know something of their habits, whether they often journey from one piece of water to another, etc., but as to this I have little or no definite information. Some edible frogs (Rana esculenta), turned loose by Mr. Henry Doubleday near a pond by his residence, it is said, "soon migrated to another pond;" 3 Mr. Darwin gives a statement, on the authority of Mr. Norgate, that newts migrate at night from pond to pond, and can cross over obstacles which

\footnotetext{
1 J. Peers, "Zoologist," xxiii. (1865), 9697-8.

"R. Standen, "Science Gossip," xxi. (1885), 28 I.

3 E. Newman, "Zoologist," vi. (1848), 2268.
} 
Would be thought to be considerable; ${ }^{1}$ and climbing powers are possessed also, both by frogs and toads, which can surmount small barriers of many kinds, but a shell upon one of the toes, though not usually much impeding ordinary progression, might seriously hinder the animals when climbing:" Mr. Peers remarked, in 1865 , that a bivalye by clinging to an amphibian "acquires a more rapid and extended locomotion than it possesses of itself, which perhaps may be a means of its distribution,".3 and in all probability he was right, for, from general considerations, it seems in the highest degree probable that such creatures occasionally carry shells from pool to pool, or from swamps and marshes adjoining rivers to ponds more or less remote and isolated, but I have not heard of their having been found, with shells attached, at any great distance from water. Three cases, which I have kept back, however, are of some significance. In I886, a newt, with a shell of Sphcerium corneum upon its right fore foot, was discovered by Mr. Hardy at the base of a wall at Dunham Massey, Cheshire, between the grass and the wall, and about ten yards from the water of a small pond, which it appeared to have left: a frog, with a shell of the same kind upon one of its toes, was once found by Mr. Standen under a $\log$ in a damp ditch about thirty yards

1 Darwin, "Nature," xxv. (1882), 529-30.

2 As to the climbing powers of frogs and toads, see "Science Gossip," I867, p. 234 ; I868, p. 94 ; xvi. (1880), 23, 64, and 165; xvii. (1881), 69 ; xviii. (1882), 215 ; “Zoologist," xxi. (1863), 8861; xxii. (1864), 8927; (2), iv. (1869), I830; (3), i. (1877), 184.

3 J. Peers, "Zoologist," xxiii. (1 865 ), 9697-8. 
from the nearest water, a pond in which Spheria were abundant: and, as Mr. Standen has recently told me, two of these shells were found by Mr. Joseph Henshall, in September, I89I, upon the toes of a newt whicl was making its way across a field, and apparently proceeding from one pond to another; when discovered it was nearly mid-way between two ponds, which are about one hundred and fifty paces apart. The shells were shown by Mr. Henshall at a meeting of the Manchester Conchological Society in January, I 892.

BIRDS.

Near White-house landing, on the Pamunky River, Virginia, it is said to be impossible to raise ducks on account of the fresh-water mussels (Unio), which catch the ducklings at low water, and hold them until drowned by the rising tide, ${ }^{1}$ and it may perhaps be assumed that the closure of bivalves upon the bills of birds of various kinds (I presume the ducklings were generally thus caught) is by no means an uncommon occurrence-it will be remembered that in the case of marine bivalves several instances have been observedbut such accidents can have little actual bearing upon dispersal: even a large and strong bird, in these circum. stances, would hardly be likely to fly to any considerable distance.

In I885, Licut.-Col. Godwin-Austen published an extract from a letter received from Mr. F. Tweedie, respecting the finding of a small bird's claw between

1 F. Mather, "Fresh-water mussels v. ducks," American Naturalist, xii. (1878), 695. 
the valves of a fresh-water mussel. His informant's sons were fishing in a pond at Hole Park, at Rolvenden, Kent, and the water being low, they were able to obtain a number of mussels, in one of which they found a claw which was regarded by the Editor of the Field, to whom it was submitted, as the "hind toe of some species of Turdus," probably a blackbird. The specimen is now preserved in the British Museum (Natural History), Cromwell Road. It appeared that the toe, the tendon of which protruded from the shell, had been torn off by the bird in endeavouring to free itself from the grasp of the mollusc. A larger bird, of course, would have flown away with the shell. As Godwin-Austen observes :-

"The great interest that surrounds this well authenticated observation is its connection with the distribution of species. The very slight divergence in the characters of the genus Unio and of Anodonta all over the world is a very well-known fact. They are constant over enormous areas, few groups are more so, and here we find an admirable example of how they must, from time to time, be carried from one piece of water, or from one river system to another. A specimen full of ova (which are particularly numerous), might in this manner be conveyed many hundred miles in a single night, when aquatic birds are on their migration, and thus stock a new habitat." 1

A large fresh-water mussel (Anodonta), upon the foot

' H. H .Godwin-Austen, F.R.S., "Bird captured by a Fresh-water Mussel," "Ficld," lxvi. (I 885), 499. 
of a redshank sandpiper (Totanus calidris) which had been taken alive with the shell attached, was exhibited at a meeting in Berlin by Mr. Schäff, in $1888,{ }^{1}$ and a few years ago, Mr. Ford, of Redhill, showed Mr. Gurney a common sandpiper (Totanus hypoleucos) said to have been caught, some time previously, on a stream in that neighbourhood, with a mussel (Anodonta or Unio?) firmly clinging to one of its feet: I hear from Mr. Ford that the bird, when found, was on the bank of the stream, about three feet from the water, and that the shell-fish had caught hold of the frog of its foot. Bivalves must almost certainly cling to birds in this manner somewhat frequently, but only a few observed instances (compared with the number noted under the two previous heads) can be given; we are fortunate, however, in having clear evidence of occasional overland transportal: a tame duck has been known to drag a heavy Anodonta across two large fields, and, what is much more important, four birds, a heron, a blue-winged teal, a duck, and a snipe having shells clinging to their toes, have been actually shot on the wing.

The case of the duck and Anodonta came under the observation of Mr. Standen when a boy. A flock of ducks belonging to his grandfather at Goosnargh used to make cxcursions to some ponds at a distance from the house, and he remembers going out one evening with several other boys in scarch of one which had not returned with the rest, and which was found, about half

1 "Sitzungs-Bericht der Ciesellschaft naturforschender Freunde zu Berlin," I $\delta \delta \delta$, pp. I $21-2$. 
way home, with a big Anodonta attached to one of its feet; it was slowly and painfully dragging the shell along, and had already crossed two large fields.

An account of the shooting of a horon with a large fresh-water mussel upon one of its feet was once related to Mr. Standen by an old gamekecper at Claughton; the bird, flying near the ground, was endcavouring to shake off the shcll-"a big horse-mussel"-which dangled from its foot, and prevented it from strctching out the leg in the usual manner. Some ycars ago a blue-winged teal (Querquedula discors), with a shell of Unio complanatus clinging to one of its toes, was shot on the wing, by Mr. H. L. Newcomb, near the Artichoke River, at West Newbury, Massachusetts. The foot and shell were given to Mr. Gray, of Danversport, whose letter to Mr. Darwin describing the case was published in Nature, in I878, together with a sketch of the specimens and a note by Darwin. The Unio, it is said, had abraded the skin of the toe, and left quite an impression." In I 884, Mr. J. W. Fcwkes recorded the shooting of a duck, on the wing, near the Sebcc River, Maine, with a "common clam" holding on to one of its feet by the middle toe. The leg (with the clam attached) was cut off, and after a day or more placed in a basin of water, when the molluse opened its shell and released the toe. The shell had probably been

'C. Darwin (and A. H. Gray), "Transplantation of Shells," Nature, xviii. (1878), I20-I; a statement by Professor R. E. Call in the American N'aturalist, xii. (1878), 473, seems also to have reference to this case. 
attached for some little time, for the toe had been chafed, and the observer heard from boys in the neighbourhood that the bird had been seen about for several days, and it seems, therefore, that the shell "had not released its grasp even when the duck lit upon the water, as it must frequently have done in the intervals of time between observation." In the same year Mr. H. V. Chapman submitted to the Field the foot of a snipe, with a shell of Spharium corneum attached to the hind toe, stating that the bird had been shot by him, while "sailing over my head with apparently a leg down." " The foot and shell have since been presented to the British Museum, and are now exhibited in the British-room at Cromwell road; the bird is said to have been shot near Rye, Sussex.

It is clear, I think, from these cases that bivalves may be occasionally carried to vast distances by birds, which, of all highly organized animals, are the least confined by geographical barriers; many annually migrate over large tracts both of land and sea, and they are occasionally blown far over the ocean by violent gales. It may be objected, perhaps, that shells are likely to drop off during long journeys, but I do not think this will often happen, for when bivalves once firmly close upon an object they generally hold on for a considerable time. But it is certain, of course, that

' J. W. Fewkes, "Ducks transporting fresh-water clamp." Auk, i. (1884), 195-6.

"H. V. C [hapman], "Accident to a snipe," Field, Ixiv. (1884), 597 , and see also p. 760. 
they must often chance to be set down in unsuitable spots; it is true, as Mr. Darwin has remarked, that a bird, such as a duck or heron, "if blown across the sea to an occanic island or to any other distant point, would be sure to alight on a pool or rivulet," " but probably a bivalve would generally remain attached for some time after the bird had landed even if kept much under water. Sooner or later, however, the valves would have to be opened, and this is more likely to happen in water than on land. It may be seriously objected, I admit, that the transplantation of a shell full of fry or ova must be a comparatively rare occurrence, and it is even doubtful, perhaps, whether a single individual in this condition would have much chance of establishing a colony in a new home. Occurrences of the kind dealt with in this chapter are perhaps, after all, chiefly significant when viewed in connection with anomalies in local distribution, and it can scarcely be doubted but that they go far towards explaining the almost mysterious presence of bivalves in isolated ponds, between which and other waters a more or less constant communication is kept up by animals of many kinds, especially by flying water-insects and aquatic birds.

Many creatures, other than those above referred to, are doubtless occasionally entrapped by bivalves. Three cases of which I have heard are perhaps worth giving, but they are not of much importance for us. 
A dead water vole with one of its fect firmly held between the valves of an Anodonta, four inches in length, was once found by Mr. Hardy on the banks of Mere Mere, Cheshire.

A snapping turtle (Chelydra), with a Unio (complanatus?), about three inches in length, clinging to its lower jaw, was caught by Mr. J. E. Todd, in I882, while on an excursion along Rock River, near Bcloit, Wisconsin. The animals, which were out of the water several rods from the river, were taken home and kept in a box, and the reptile was seen to make frequent and vigorous attempts to push off the clam with its fore legs, but without success, for when it escaped from confincment after two or three days it carried away the shell still attached to its jaw. The end of the jaw probably reached to about the middle of the inside of one of the valves, so that the mollusc would no doubt be considerably injured, but, ultimately releasing its grasp in a suitable place, it might possibly recover. ${ }^{1}$

In I 855-6 Professor Girard found numbers of small bivalves attached to crayfishes (Astacus fluviatilis) in ponds in the environs of Brie-Comte-Robert, Scine-etMarne. Every crayfish taken from a pond called "la mare à l'Anglais" had shells upon its toes; another pond, close by, also contained individuals similarly cncumbered, and a man living at Brunoy, who was in

1 J. E. Todd, "Chelydra versus Unio," American Naturalist, xvii. (1883), 428; see also "Nachrichtsblatt der Deutschen Malakozoologischen Gesellschaft," IS83, p. 93; and I am indebted to Mr. Todd for having communicated some additional particulars, 
the habit of procuring these animals for the market, informed the observer that he had noticed the same phenomenon in some other ponds in the neighbourhood. Sometimes every one of the cight ambulatory legs had a shell clinging to it, so that the animal appeared as if wearing clogs. The shells in question are spoken of as "Cyclas fontinalis," but as Mr. Heynemann, who had the kindness to draw my attention to these

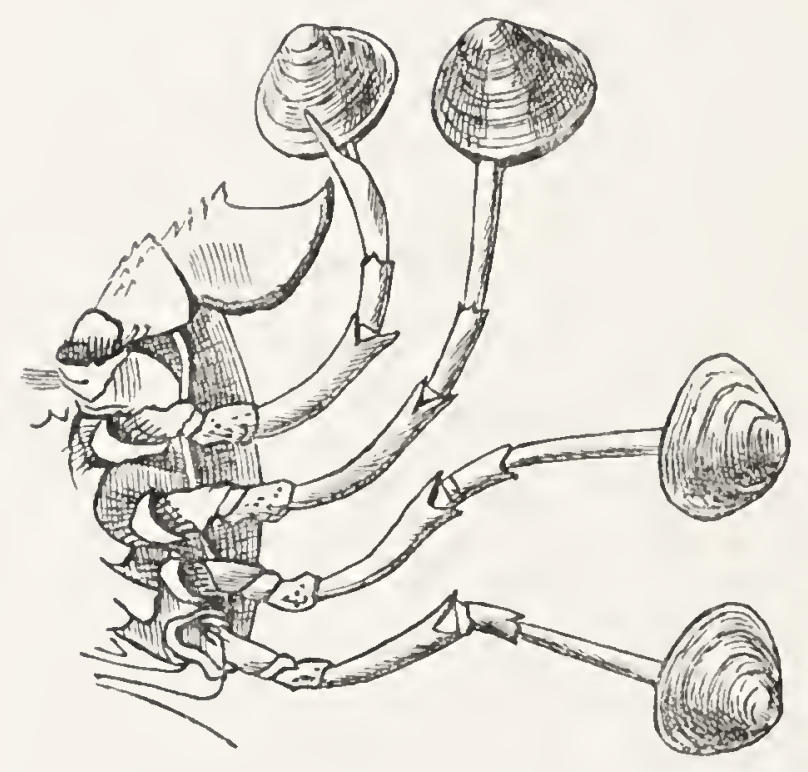

rIG. 6.

"Astacus fluviatilis \& Cyclas fontinalis." After Girard, "Annales de la Société entomologique de France," (3), vii. (1859), pl. 4, fig. r.

observations, points out, M. Girard describes and figures a much larger shell (Fig. 6). ${ }^{1}$

Professor Rossmässler ${ }^{2}$ mentions that zebra mussels (Dreissena polymorpha) have frequently been found attached, by the byssus, to the tails of crayfishes.

1 Professor Girard, "Annales de la Société entomologique de France," (3), vii. (1859), I37-142.

"As quoted in "Ann. and Mag. Nat. Hist.," (3), xviii. p. 494. 


\section{CHAPTER IV.}

TRANSPLANTATION OF UNIVALVES.

OPERCULATL water-snails, it seems possible, may sometimes be transported while clinging by closure of the operculum to the legs of aquatic creatures of certain kinds. Water-beetles and other such animals, walking amongst the branches of aquatic weeds or upon the mud at the bottoms of pools and slow-flowing rivers, must occasionally insert their legs into the mouths of these shells, and, if the operculum be quickly closed, the mollusc may possibly cling firmly, and may be carricd about by a sufficiently strong animal for a considerable time. A large and strong-flying waterbeetle, in such a case, might obviously carry a shell of small size from one piece of water to another. One little observation, more or less apposite, has been made. the aquatic larva of a dragon-fly having been seen by Mr. Hardy in May, I890, with one foot firmly held between the operculum and lip of a specimen of Bythinia tentaculata, and it is interesting to find, also, that a humble-bee has been seen with an operculate land-shell holding on to one of its legs in a similar 
manner. ${ }^{1}$ I cannot think, however, that the operculate pond-snails often cling in this way, and, as already mentioned, those with which we are familiar in this country are known to be very generally absent from perfectly isolated waters. ${ }^{2}$ In July, I89I, I experimented, with grass-stems, on a good number of specimens of Paludina vivipara in the Lea marshes at Tottenham, and it seemed hardly likely that animals chancing to insert their toes into the mouths of these shells would often be entrapped, for the opercula were not firmly closed with sufficient suddenness. Most of the specimens which were induced to hold on to the inserted stems dropped after a minute or two; one, however, did not fall until I had carried it, suspended upon the stem, for more than half an hour, but a sharp jerk would probably have caused it to drop almost immediately.

The fresh-water limpets (Ancylus), inoperculate univalves which generally adhere to stones and waterplants in ponds and rivulets, were specially mentioned by Reeve as having very limited facilities for migration. ${ }^{3}$ But they sometimes ride upon the backs of large flying water-beetles! The taking of a great waterbeetle (Dytiscus) with an Ancylus firmly adhering to it

${ }^{1}$ F. W. T., "Humble-bee trapped by snail," Field, lxv. (1885), 843.

"See Clement Reid, on the "Natural history of isolated ponds," "Trans. Norfolk and Norwich Nat. Soc.," v. (1892), 279.

${ }^{3}$ Lovell Reeve, "Land and Frcsh-water Mollusks," I863, p. 255 . 
was mentioned by Darwin (on Lyell's authority) in the "Origin of Species" in I $859 ;^{1}$ in I 876, Mr. E. Duprey stated that he had more than once seen young specimens of A. fluviatilis adhering to another common water-beetle, Acilius sulcatus, ${ }^{2}$ and I hear that Mr. Hardy once found a specimen of Dytiscus marginalis with three shells of $A$. lacustris adhering to the wingcases, one on the left and two on the right side. Carried by these insects "from pond to pond," as Lyell and several authors have surmised, the creatures could be quickly distributed, of course, over a large tract of country. That they are occasionally thus carried seems conclusively proved by an observation made by $\mathrm{Mr}$. Standen, who was fortunate enough to detect a shell of A. Aluviatilis upon one of the wing-cases of a Dytiscus caught on the wing after dusk on the evening

'See "Origin," I 859, pp. 385-6; ed. vi., p. 345; I have not been able to ascertain by whom this beetle was taken, and the only mention of the occurrence by Lyell himself, as far as I am aware, is contained in a letter, dated in I86I, to his nephew, then a boy of ten, who had been finding specimens of $A$. fluviatilis :- "Naturalists used to wonder how this Ancylus got spread over the country in separated lakes and streams, till someone found a young Ancylus adhering to the elytra of one of those large boat-beetles, Dytiscus marginalis, which you will see in the collection at Drumkilbo, and which fly about at night from pond to pond, and may sometimes carry the Ancylus with them, if, like the Patella which you saw high and dry on the rocks here, he can manage to do without water for an hour or two, as most probably he can." "Life, Letters, and Journals of Sir C. Lyell," ii. (I881), 347.

"E. Duprey, "Ann. and Mag. Nat. Hist.," (4), xviii. (1876), 344 ; and see also Rimmer's "Land and Fresh-water Shells," (1880), p. 70. 
of May 8th, I890, at Birch, near Manchester, about fifty yards from the nearest water.

Ancylus fuviatilis and allied molluscs frequently adhere to the shells of the large fresh-water mussels, Unio and Anodonta; for instance, Mr. Baker Hudson, who has collected large numbers of pearl mussels (Unio margaritifer) from the Yorkshire Esk, has found A. fluviatilis to occur on at least sixty per cent. of them, ${ }^{1}$ and this suggests another possible mode of dispersal which may have come into operation once every now and then in the course of ages, for a bird carrying a large bivalve clinging by closure to its toe might obviously transport these limpet-like shells also, for short distances at any rate, so that it is just within the range of possibility that a newly formed pool might be simultaneously stocked by a bird with a univalve and a bivalve, molluscs as widely dissimilar as are Ancylus and Unio or Anodonta.

Fresh-water limpets and inoperculate pond-snails of various kinds are known to crawl occasionally upon the backs or limbs of frogs and other aquatic or amphibious creatures. Mr. W. Thompson, in I84I, mentioned that he once saw numbers of Limnca peregra (a common pond-snail) attached to the backs of some turtles kept in a pond at Fort William, near Belfast, and they appear to have held on with some firm-

1 And see A. M. Norman, "Zoologist," xi. (1853), 3763; Tate, "Land and Fresh-water Mollusks," (I \$66), p. 207; H. Pollard, "Naturalist," I887, p. I 38 ; H. A. Pilsbry, "Nautilus," iv. (I890), 48. 
ness, for the turtles were "swimming about with the Limnee still keeping "their seats' upon them." $\mathrm{Mr}$. Jenkins has seen molluscs of various kinds, both young and adult, crawling upon the bodies of frogs, toads, and newts kept by him from time to time. In such positions, no doubt, the creatures are occasionally carried for short distances overland from one piece of water to another. Two observations bearing directly on the point can be given. A small living shell of Ancylus lacustris was detected by Mr. Baker Hudson adhering to one of the legs of a frog caught, hopping through the grass by the side of a footpath, in Cowpen Marsh, County Durham, perhaps thirty yards from the nearest water, the main drainage dyke of the marsh; and a full-grown specimen of Limnce peregra was seen by Mr. Standen, in I883, upon the back of a toad which was tramping leisurely along the road, in the dusk of evening, at Goosnargh, about twenty yards from the water of a roadside pond." I am not aware that any animal has ever been seen to enter the water with a shell adhering; such an observation-which is within the bounds of possibility-would certainly be "of the nature of a great good fortune."

' W. Thompson, "Catalogue of the Land and Fresh-water Mollusca of Ireland," "Ann. and Mag. Nat. Hist.," vi. (184I), II9.

"This observation was referred to by Mr. Standen in "Science Gossip," xxi. (1885), 281, and quoted by me in the "Naturalists' World," iii. (1886), 6 I. 


\section{CHAPTER V.}

LAND SHELLS: THEIR TENACITY OF LIFE.

AMONG land-shells some of the species are spread over large areas: of this our own little white snail (Helix pulchella), which independently of dissemination by human agency seems to have had a very extensive range, is a familiar example, and many others might be mentioned; Professor Semper has remarked upon the fact that the species of Trochomorpha (a sub-genus of Helix) are extremely similar in appearance whether they come from India, the Moluccas, the Philippines, or the islands of the Pacific, and several, he says, are distributed throughout this vast region almost without any variation in their shells. ${ }^{1} \quad$ But as a general rule terrestrial species are restricted in distribution, and often wonderfully so ; most islands, even very small ones, have some peculiar species, and it is even found that single mountains or valleys sometimes possess species or varieties found nowhere else in the world." It is notorious, for

1 K. Semper, "Animal Life," ed. 4, 1890, p. 288.

"See Wallace, "Geographical Distribution," ii. (1876), 524 ; "Island Life," 1880, p. 76 ; ed. 2, (1892), p. 78. 
LAND SHELLS: THEIR TENACITY OF LIFE. 9I

instance, that numbers of species are confined to the Madeiras, ' and the islands Madeira and Porto Santo, each in sight of the other, possess assemblages of land-shells which, though representative, are for the most part different or proper to each. ${ }^{2}$ From the Sandwich Islands betwcen three and four hundred species of land-shells have been described, and all, it is said, are endemic! In the sub-family Achatinelline (entirely confined to the islands) the average range of a species, according to the observations of the Rev. J. T. Gulick, is "five or six miles, while some are restricted to but one or two square miles, and only very few have the range of a whole island." It is even said that each valley, often each side of a valley, and sometimes each ridge or peak possesses its own peculiar species. $^{3}$

Fresh-water species, in some groups at least, generally range much more widely than terrestrial species, and it might at first sight seem probable that the former possess far greater facilities for overcoming natural barriers-indeed the latter seem to have been regarded by some writers as practically destitute of all means of dispersal ${ }^{4}$ - but it scems improbable that such is the case, for certain terrestrial genera and higher groups

See R. B. Watson, "Journ. of Conch.," vii. (1S92), 4-5.

2 Lyell, "Antiquity of Man," ed. 4, I873, p. 496.

3 Wallace, "Island Life," pp. 303-4; ed. 2, pp. 316-I 8 ; J. T. Gulick, "Journ. Lin. Soc.," I 873, p. 496, and "Proc. Zool. Soc.," I 873 , p. So, as quoted by Mr. Wallace.

4 See, for instance, H. H. Higgins, "Proc. Lit. and Philos. Soc. Liverpool," xxxvi. (1882), pp. xliv-xlv. 
range very widely, some having species scattered at random in various parts of the world, ${ }^{1}$ and almost all oceanic-islands (even those in which fresh-water shells are very scarce or altogether absent) are inhabited by land-snails, often in great plenty and variety. Many of the genera and ligher groups have limited ranges, but it is notorious that some of the families and genera are almost universally distributed. The family Helicida, a group of immense extent, is described as absolutely cosmopolitan in its range, being found in the most barren deserts, and on the smallest islands, all over the globe, and reaching to near the line of perpetual snow on mountains, and to the limit of trees, or even considerably beyond it, in the arctic regions: the genus Helix also is said to be universal, having found its way to every country and to almost every island in the world; several other genera with very wide ranges might be named; c.g., Pupa, like Helix, inhabits each of the six zoological regions. ${ }^{2}$ Mr. Wallace has maintained that all the animals now inhabiting truly "oceanic islands" must have reached them by crossing the ocean or be the descendants of ancestors which did so, for such islands have been produced in mid-ocean and have never formed part of a continent; but in some cases, of course, the creatures may possibly have migrated from former and unknown lands lying nearer

1 See Wallace, "Geographical Distribution," ii. (I 876), pp. 5 I2-13, 522 .

2 "Geographical Distribution," ii. (1876), pp. 512-13, 522 ; "Island Life," p. 76 ; ed. 2 , p. 78 . 
to the islands than the nearest now existing countries. The Azores or Western Islands, lying at a great distance from the nearest continental land, and separated therefrom by an ocean of great depth, have been specially referred to by Mr. Wallace as typical "oceanic islands," and they possess land-shells in some plenty, sixty-nine species having been recorded for the group, thirty.seven of which are common either to Europe or the other Atlantic islands, and thirty-two peculiar, but almost all allied to European types; on the other hand, though there are streams, springs, and lakes, apparently presenting the most favourable conditions for the existence of molluscs, not a single fresh-water species has yet been discovered.' The wholly volcanic and strictly oceanic island of St. Helena, only about ten miles long by eight wide, and so remarkable for its extreme isolation, situate as it is nearly in the middle of the South Atlantic, I roo miles from Africa and 1800 from America, possessed twenty truly indigenous species of land-shells (a large proportion of which have unfortunately become extinct since the destruction of the forests); and several others, probably recently introduced by man, now occur in the island. Here, as in the Azores, fresh-water shells are altogether absent, the streams and tanks of the interior, the trickling rocks, waterfalls, and pools, being all uninhabited by molluses of aquatic genera. ${ }^{2}$ The Sand-

"Island Life," pp. 236-7, 239-40, 247, and 293; ed. 2, pp. 245 , $247-8,256$ and $305 ; \mathrm{H}$. B. Tristram, as quoted by Wollaston, "Testacea Atlantica," I 878, p. 6.

" "Island Life," Pp. 281 and 293 ; ed. 2, pp. 292 and 304 ; Wollas- 
wich Islands, wonderfully isolated in mid-ocean, are inhabited, as we have just seen, by three or four hundred land species, and possess only " a few fresh-water shells." It seems evident enough from facts of this kind that effectual means for occasional transportal are certainly possessed by land-molluscs, and even in local distribution within a given country we see much which in the absence of means for dispersal, at least over land, would seem well-nigh inexplicable, for more or less isolated colonies of certain species are not unfrequently found at great distances from others of their kind. Mr. Standen adverted to this subject in a communication with which I was favoured in I89I, remarking that he had often pondered over the question as to "how and when certain colonies of land-shells had become located in various queer places," and referring, for instance, to two singular colonies of Vertigo pygmaa in which the creatures live in great abundance within limited areas, and to the presence of the heath-snail, Helix ericetorum, on a little bit of rough land in the middle of a cultivated field, many miles from any other habitat of the species. In Norfolk, according to

ton, "Testacea Atlantica," 1878, p. 6; more recently the total number of land-shells truly indigenous to St. Helena has been estimated by Mr. Edgar Sinith as twenty-seven, of which, it is said, seven only are now living on the island, the remainder having been exterminated by the destruction of the forests: see report of the Zoological Society's meeting on 5th April, 1892, in "Nature," xlv. (1892), p. 597.

1 "Island Life," pp. 293, 298, and 303; ed. 2, pp. 305, 310, and 316. 
Woodward, Cyclostoma elegans is found in the greatest profusion on the bosses of chalk that appear among the overlying Tertiary gravels and clays, and is not met with in the intervening areas. ${ }^{1}$

Mr. Reeve, it will be remembered, took it for granted that these creatures possess even "greater facilities of migration " than the fresh-water kinds, ${ }^{2}$ but this conclusion was not based upon definite data and has but little value; one is certainly inclined to agree with Mr. Belt, however, in thinking that the land species "have at least equal means of dispersion, compared with the sluggish, mud-loving, water-shells of our ponds and ditches;" 3 but, if this be so, how is it that the species of the one group are generally confined to small areas while those of the other are frequently widely diffused?

In the first place it may be remarked that the wonderfully restricted distribution of many terrestrial molluscs cannot be taken as implying an absence of means for occasional transport, though, of course, frequent or constant transportal might have largely hindered divergence. It must not be supposed, $\mathrm{Mr}$. Darwin points out, that species which have the capacity of crossing barriers will necessarily range widely, for this implies, not only the power of crossing barriers, but the more important power of being victorious in the

1 S. P. Woodward, as cited by Tate, "Land and Fresh-water Mollusks," 1866, p. 222.

"L. Reeve, "Land and Fresh-water Mollusks," 1863, p. 252.

3 T. Belt, "Naturalist in Nicaragua," ed. 2, 1888, p. 334. 
struggle for life with foreign associates.' When in free intercommunication closcly-allied species are not always able to invade cach other's territory; two equally well fitted for their own places seem likely to be able to hold their separate habitats for almost any length of time." The Achatinellinæ of the Sandwich Islands, just referred to, so remarkable for limited specific areas, have in all probability been occasionally, though perhaps very rarely, carricd by accidental means into the midst of each other's districts, but, as their distribution clearly indicates, they must generally have failed to establish themselves in the new surroundings, being unable, no doubt, to compete successfully with those already in possession. Sir C. Lyell has expressed surprise that "in the course of that vast lapse of ages which has occurred since the Newer Pliocene period" the shell-faunas of Madeira and the adjacent islet, Porto Santo, have been so little interchanged; ${ }^{3}$ but in all probability shells have been occasionally carried from one island to the other by natural agencies; if both are well stocked, however, and if the respective faunas are equally well able to hold their own as against the other, they are not likely to be much affected by the occasional transportal of a few individuals. Some of the characteristic Porto Santo species live in crevices of stone, and it is probable that they have often been transported to Madeira by human agency with the large quantities of stone annually

$$
\begin{aligned}
& 3 \text { "Origin," p. } 358 . \quad \text { "Origin," p. } 356 . \\
& \text { "Principles," ed. 12, ii. (1875), p. } 433 \text {. }
\end{aligned}
$$


carried there from Porto Santo, but they have not colonized the island; on the other hand, European land-shells, believed to have been introduced by man, are said to flourish both in Madeira and Porto Santo. ${ }^{1}$

It must be admitted that neither fresh-water nor landshells are really well furnished with means for dispersal; the transportal of a species of either group over a large cxpanse of ocean, or to great distances on land, with subsequent establishment, must be an extremely rare and exceptional occurrence, and one which happens, perhaps, only once or twice in many hundreds of years. It can hardly be argued, therefore, that fresh-water species have been kept uniform by constant or frequent transportal. Numerous facts, it is true, apparently indicating means of dispersal for fresh-water kinds have been referred to, and these are doubtless of value as helping us to understand how it is that many have been able to wander so far from their several birth-places, but it cannot be said that they explain the wide ranges and consequent uniformity which obtain in fresh-water as against more restricted ranges and greater variety on land.

It secms cvident, as Mr. Belt has remarked, that on land there has been more variation or that the varicties which have arisen in fresh-water have less frequently been preserved. Mr. Darwin has shown that in freshwater competition will have been less severe than on land, and consequently new forms will have been more slowly produced;" but this consideration, taken alone, is per-

$$
1 \text {. Origin," p. } 35 \% \text {. "Origin," P. } 83 .
$$


haps insufficient to account for the difference in specific distribution which the terrestrial and non-marine aquatic groups of mollusca cxhibit. The problem presented is of importance, and a solution of it, which seems likely to be the true one, has occurred to Mr. Belt, who has pointed out that the variation of fresh-water species of animals and plants has probably been constantly checked by the want of continuity of lakes and rivers in time and space :-

"In the great oscillations of the surface of the earth, of which gcologists find so many proofs, every fresh-water area has again and again been destroyed. It is not so with the ocean-it is continuous -and as one part was elevated and laid dry, the species could retreat to another. On the great continents the land has probably never been totally submerged at any one time; it also is continuous over great areas, and as one part became uninhabitable, the land species could in most cases retreat to another. But for the inhabitants of lakes and rivers there was no retreat, and whenever the sea overflowed the land, vast numbers of fresh-water species must have been destroyed. A fresh-water fauna gave place to a marine one, and the former was annihilated so far as that area was concerned. When the land again rose from below the sea, the marine fauna was not destroyed -it simply retired farther back. There is every reason to believe that the production of species is a slow process, and if fresh-water areas have not continued as a rule through long geological periods, we can see how 
variation has been constantly checked by the destruction, first in one part, then in another, of all the freshwater species; and on these places being again occupied by fresh-water they would be colonized by forms from other parts of the world. Thus species of restricted range were always exposed to destruction because their habitat was temporary and their retreat impossible, and only families of wide distribution could be preserved. Hence I believe it is that the types of fresh-water productions are few and world-wide, whilst the sea has molluscs innumerable, and the land great variety and wealth of species. This variety is in the ratio of the continuity of their habitats in time and space." '

Before procecding, in Chapter VI., to a consideration of possible means for the dispersal of land-shells, I will venture to append here a small collection of facts on their tenacity of life. As is well known, some of these creatures possess in a remarkable degree the power of retaining vitality under conditions of the most adverse kind, being able to live for long periods, even for years, without either food or moisture; and this faculty must doubtless be of the greatest use to them in their involuntary migrations, during, which they must often suffer great hardships; and thus it seems likely that they are fitted for transportal by means which can never operate for frailer creatures. Even if they have had to depend almost solely on voluntary migration, as some writers seem to suppose, the ability to remain dormant

1 T. Belt, "Naturalist in Nicaragua," ed. 2, I888, pp. 334-5. 
for considerable periods must have been highly useful, for we find that many linds have learnt to evade the cold of winter by hibernation and the excessive heat and dryness of summer by restivation, and thus they have been able to overcome climatic conditions which in other circumstances might have bcen fatal, and some kinds, having learnt to continue the latter process for great lengths of time, have been able to penetrate the dryest deserts. It is important, of course, to inquire also as to what extent the creatures are able to withstand the notoriously harmful effects of contact with sea-water, for on this the value of certain suggested means of trans-oceanic dispersal obviously depends; but I know only one or two facts bearing upon the point, and these can be conveniently referred to in the next chapter.

One of the most remarkable cases of long-suspended vitality I have anywhere seen recorded is given in Bingley's "Animal Biography," vol. iii. p. 574," where some snails-on being immersed in water-are said to have recovered and crept about after an uninterrupted torpidity of more than fifteen years :-

"Mr. Stuckey Simon, a merchant of Dublin, whose father, a Fellow of the Royal Society, and a lover of natural history, left to lim a small collection of fossils and other curiosities, had among them the shells of some snails. About fifteen years after his father's death (in whose possession they continued many years), he by

1 As quoted by G. J[ohnston]., Loudon's "Mag. Nat. Hist.," vii. (I834), pp. II 3 -I 4 . 
chance gave his son, a child about ten years old, some of these snail shells to play with. The boy put them into a flower-pot, which he filled with water, and next day into a basin. Having occasion to use this, Mr. Simon observed that the animals had come out of their shells. He examined the child, who assured him that they were the same he had given him, and said he had also a few more, which he brought. Mr. Simon put one of these into water, and in an hour and a half observed that it had put out its horns and body, which it moved but slowly probably from weakness. Major Vallancey and Dr. Span were afterwards present and saw one of the snails crawl out, the others being dead, most probably from their having remained some days in the water. Dr. Quin and Dr. Rutty also examined the living snail several different times, and were greatly pleased to see him come out of his solitary habitation after so many years' confinement. Dr. Macbride, and a party of gentlemen at his house, were also witnesses of this surprising phenomenon. . . . A few wecks afterwards the shell was sent to Sir John Pringle, who showed it at a meeting of the Royal Society ; but some of the members imagining that Mr. Simon must have been imposed upon by his son having substituted fresh shells for those that had been given to him, the boy was reexamined by Dr. Macbride on the subject, who declared that he could find no reason to believe that the child either did or could impose upon his father. Mr. Simon's living in the heart of the city rendered it almost impossible for the boy (if he had been so disposed) to collect 
fresh shells, being at that time confined to the house with a cold. Mr. Simon has also declared that he is positive those were the shells he gave to him, having in his cabinet many more of the same sort, and nearly of the same size."

Dr. Johnston, who quoted this account in I 834, agreed with Mr. Bingley in regarding the facts as well authenticated, but the period during which the snails are said to have remained torpid is exceptionally lengthy, and I do not think that the evidence is quite conclusive.

HeLIX DESERTORUM.-More satisfactory than the foregoing is Dr. Baird's celebrated and often quoted account of a desert sn'il ( $H$. desertorum) which remained for four years fixed upon a tablet in the British Museum, and subsequently revived and lived some time in captivity. Two specimens which had been collected in Egypt, it appears, were presented to the Museum in March, I846, and on the $25^{\text {th }}$ of that month they were fixed upon tablets and placed in the collection among the other mollusca, where they remained till about the I 5 th of March, I850, when owing to the fact that a glassy-looking, and evidently recently-formed, epiphragm was seen to have been formed in the mouth of one of the shells, both were removed and placed in tepid water, and, after the lapse of ten minutes, the animal of one was seen to gradually come forth, and in a few minutes more it was walking along the surface of the basin in which it had been placed: next day it was supplied with part of a cabbage-leaf of which it partook readily though in small quantity, and on the 24 th of 
June, the date on which the account was written, it was still alive and in apparent health, preferring cabbageleaf to lettuce or any other kind of food which had been tried.' Dr. Baird's notice was accompanied by a drawing of the living animal, made by Miss Waterhouse, which now forms figure 2 in Woodward's "Manual." The animal in the other shell was found to be dead. About I858, two other specimens of the same kind of snail, believed to have been dormant for more than four years, were sent to the Museum by Mr. B. M. Wright. They are said to have been collected in May, I 854, from a heap of thorn bushes, by Mr. Vernèdi, on his journey through the Desert of Egypt: the bushes were rather thickly studded with snails, and fifteen or twenty specimens which were picked off were carried home and locked up in a drawer, where they remained undisturbed till September, I858, when two were given to Mr. Wright, who tried with success the experiment of reviving them, and afterwards $\mathrm{Mr}$. Vernèdi himself succeeded with two of the others. The elder Binney relates that specimens of this snail which had been collected in Egypt and shipped to Smyrna, thence to Constantinople, thence to Rio Janeiro, and finally to Boston, occupying a period of about seven months, appeared in good health when taken from the papers in which they had been enveloped, and after having lain in a drawer for three years, some of them still came out in tolerable

1 According to a label now affixed to the specimen in the Museum, the creature continued to live, after its revival, for two years. 
vigour.' Mr. Jenner Weir has been good enough to inform me of the resuscitation of a snail, believed to belong to this species, which had been in his possession, in a dormant state, for about a year.

Helix LACTEA. - Concerning this snail a case of much interest has been recorded by Mr. J. S. Gaskoin. $\Lambda$ specimen, which appears to have contained fertile eggs when captured, and which had subscquently remained torpid for more than four ycars, revived and lived for some time, alone, under a bell-glass, where, notwithstanding the long suspension of animation, it became surrounded with a family of about thirty "points" or young ones. In April, I 849, four or five specimens, which had been obtained from a dealer, were placed in water to be cleaned for the cabinet, and in the course of an hour or two one of them resuscitated and escaped from the vessel. The shells had been selected from many others, ail of which had been stored in a dry dusty drawer in the dealer's shop for more than two years, and had been imported by a merchant of Mogador, in whose possession they had been, in a similar condition, for a still longer period. The test of submersion in water was tried with the whole of the dealer's stock, but all seemed to be dead. The individual which had revived was placed, quitc alone, under a large bell-glass on a tub of earth, and lived well on cucumbers, cabbage-

1 W. Baird, "Ann. and Mag. Nat. Hist.," (2), vi. (I 850). pp. 68.9; Woodward's "Manual," ed. 4, rep. 1890, pp. 4 and 14 ; S. P. Woodward, "Ann. and Mag. Nat. Hist.", (3), iii. (1859), p. 448; A. Binney, "Terr. air-breathing Moll.," i. (185 I), pp. $196-7$. 
LAND SHELLS: THEIR TENACITY OF LIFE. IO5

leaves, etc., and at the end of the following October it was found to be accompanied by about thirty minute black helices, of the origin of which the observer was at first doubtful, but the markings and form of $H$. lactea soon became distinguishable, and when the account was written, a year later, some of them were nearly as large as the parent, which was still alive in captivity. In Africa, in certain parts of the descrts where there is a constant heat of over $110^{\circ}$ Fahr., and where no trace of vegetation can be seen, the ground is sometimes covered with $H$. lactea so as to seem whitened, and at the end of I 858 Aucapitaine is said to have collected specimens while passing through places, where, it was believed, no rain had fallen for five years; these were packed away in a box and forgotten until August, I862, when they were found, and placed in a basin of water to be cleaned, and next morning, to his astonishment, the observer found them, full of life, crawling about on the furniture of his study.'

HELIX APERTA. - Woodward placed a specimen of this species in a glass-box in June, 1855 , and it remained quiescent, without food or change of air, until November, 1856 , when, on being placed in water, it revived for a few hours, but returned, without taking any food, to its former condition, and so continued until July, 1857, when it was required for dissection. In February, I885, Mr. Darbishire bought a quantity of snails of this hind in the market at Nice,

1 J. S. Gaskoin, "Proc. Zool. Soc.." I S50,pp. 243-4; Aucapitaine, .1s cited by .Mr. I)arbishire, "Journ. of Conch.." vi. (1SS9), 101. 
of which a few, having their shells sealed up with strong calcareous lids, were packed away in cottonwool and kept in a workshop until December, I888, by which time they seemed to have lost the weight and coolness usually characteristic of life, and one, when broken, showed the animal dried up like a bit of hard horn; but two others, laid on a pad of flannel under a shade, and thus kept in a moist atmosphere, after a few weeks showed signs of life, and were then removed to a damp fern-case, where, in the following March, they were seen walking out, somewhat feeble, but in good colour and substance.'

Helix Candidissima and H. vermiculata.Two specimens of $H$. candidissima, placed in a box by Woodward, in June, 1855, with the specimen of $H$. aperta just referred to, remained dormant till November, 1856, when they were immersed in water and revived for a few hours; on being put back into the box, however, they became dormant again without feeding, and in July, I857, when the $H$. aperta was removed for dissection, another individual of $H$. candidissima and one of $H$. vermicularis [? $H$. vermiculata] were put in with them, and all four remained in a torpid state until Michaelmas, 1858 , when the observer conveyed the box in his pocket to the British Museum, and the snails were all excited to activity by the warmth and shaking they experienced. In April, I859, when a note of the facts was written for publica-

${ }^{3}$ S. P. Woodward, "Ann. and Mag. Nat. Hist.," (3), iii. (1859), 448; R. D. Darbishire, "Journ. of Conch.," vi. (1889), IOI. 
LAND SHELLS: THEIR TENACITY OF LIFE. IO7

tion, the creatures were still alive under a bell-glass, along with several other foreign snails which had been received at the Museum in a living state. ${ }^{1}$ Specimens of $H$. vermiculata and of a species of Leucochroa, it is stated, have survived a confinement of two years in a leaden case. ${ }^{2}$

HELIX HORTENSIS.-A specimen which had been collected in August, I843, and laid by and forgotten until April, I844, on being placed in a window, soon crawled upon one of the panes, attached itself to the glass, and remained there until the following October, when it was broken down by accident, and soon after died, having lived without food for fourteen months. ${ }^{3}$

HELIX ASPERSA.-A specimen of H. aspersa, observed by Mr. J. Ward, survived in a closed pot of earth for about ten and a half months, and, as it is interesting to note, subsequently produced fertile eggs. Two individuals were enclosed in the pot at the beginning of July, I878, immediately after copulation, and when taken out for examination about the middle of May, I879, one was found to be dead-not a vestige remaining except the empty shell-but the other, though the animal had shrunk to about a third of its former bulk, on being moistened and supplied with food, revived and fed, and after about two months deposited ova, the

' S. P. Woodward, "Ann. and Mag. Nat. Hist.," (3), iii. (1859), p. 448 .

"O. Reinhardt, in "SB. nat. Fr.," 1886 , pp. 55-6, as quoted in the "Zoological Record," xxiii. (1886), Moll., p. 102.

" H. T. Harding, "Zoologist," ii. (1844), 800. 
greater part of which hatched out, so that "a little colony of vigorous young snails" was established. According to a statement in the American Naturalist, in ISSO, another individual has been known to live "without food" for thirteen months; but two, enclosed in a wooden box by Mr. Gude in August, I89I, were both clead when examined after about thirteen and a half months. ${ }^{1}$

HELIX PISANA.-A snail of this species, collected by Mr. O. V. Aplin about the middle of August, ISSr, and overlooked, was found to be alive on I 8 th June, I $\$ S 2$. On being placed in a jar of water-the epiphragm having bcen previously broken away-it crawled out in less than an hour and a quarter, and was apparently none the worse for its ten months' sleep. ${ }^{2}$

HELIX FRASERI.--Some examples of this snailwhich does not form an epiphragm-brought to Sydney by a collector from the Richmond River, New South Wales, in April, I 990 , were kept by Mr. Musson, wrapped in paper, in an open cigar-box on a shelf, for about ten months, and on examination at the end of this period were found to be alive.

Helix veatChil.-A specimen of $H$. veatchii, from Cerros Island, is said to have "lived without food from I 559 , the year when it was collected, to March, I865, a period of six years." 3

1 J. Ward, "Nature," xx. (I879), 363; Lockwood, "Am. Nat.," xiv. (I880), p. 214, as quoted in the "Zoological Record," xviii. (IS81), Moll., p. I6.

" O. V. Aplin, "Midland Naturalist," v. (I882), p. 2 Io.

${ }^{3}$ R. E. C. Stearns, "Am. Nat." xi. (1877), roo, and "Proc. 
LAND SHELLS: TIIEIR TENACITY OF LIFE. IO9

HELIX UNDATA AND OTHER SNAILS FROM TIIE MADEIRAS.-Mr. Gaskoin mentions having received from Mr. Wollaston several species of living snails, mostly Hclices, indigcnous to Madeira and its adjacent rocks, which, though they had lain in a box in dry canvas bags for a year and a half, had been. revived by immersion in water. They were put under glass shades on flower-pots filled with mould, or in large glass cases, and all fed frecly; three specimens of the beautiful H. undate, Lowe, produced more than two hundred small pearl-like eggs, and some of the other species also oviposited. Mr. Pickering is said to have received from Mr. Wollaston a basketful of Madeira snails (of twenty or thirty different species) three-fourths of which were revived "after several months' fasting and captivity," including a sea voyage. On the same subject a communication of much interest was published by $\mathrm{Mr}$. Wollaston in $\mathrm{I}_{50} \mathrm{O}$ :

"During my residence in the island of Porto Santo, from April 27th to May 4th, IS48, I collected a large quantity of Helices peculiar to the spot, and having placed a small set of each, as types, in separate pill-boxes (for examination by $\mathrm{Mr}$. Lowe on my return to Madeira), the rest were killed. 'These types were named the following week by Mr. Lowe, and as I had to leave immediately for England, I had no time to kill the specimens. On my return home the boxes were

California Academy of Sciences," October 18th, 1875, as quoted in "Ann. and Mag. Nat. Hist.," (4), xix., pp. $355-6$ and "()uart. Journ. Conch.," i., p. 2 IS. 
placed in empty drawers of my insect cabinet, since which, up to the present time (October I9th, I850), they had never been opened, or if opened, the specimens had certainly never been taken out. I concluded of course that they were dead long ago, thinking it more than probable that they never survived the voyage to England, and therefore, à fortiori, that two years and a half in dry pill-boxes was quite sufficient to remove all traces of existence. However, by immersion in cold water, I find that many of them are still alive; and though a large proportion have perished in this long interval, yet I have fourteen specimens now before me crawling about with the greatest activity. Thirteen of these are of the same species, viz.: Helix (Carocolla) papilio, Lowe, and the other Helix tectiformis, Lowe, both collected May Ist, I848, on the Ilheo de Baixo, a small limestone island off the south-western extremity of Porto Santo. . . . I may also mention that I possess a whole bagful of the beautiful little Helix turricula, Lowe, collected on the Ilheo de Cima (another and smaller rock, off Porto Santo), on the 24th of April, I849, all of which, I find by immersion, are alive, though the dry and dusty bag in which they have been enclosed has never been opened since they were placed there, exactly a year and a half ago. The same may be said of Helix duplicata $[=H$. bicarinata, Sow. $]$ and paupercula, of Lowe, (collected at the same time as the last); I have both in large quantities, perfectly active, though only now for the first time taken out of the boxes in which they were 
originally placed. I have also a few specimens of a minute Madeira species, Helix lentiginosa, Lowe, which I have ascertained to be alive, although they are so small that it is difficult to conceive how sufficient moisture to support life can have been retained through this long period."

Three specimens of Helix bicarinata (Porto Santo), recently obtained from an English dealer and kept by Mr. Gude in a glass-topped box for fifteen or sixteen months, on being tested in water, proved to be alive and crawled freely about among damp moss.

BULIMUS PALLIDIOR is said to have survived confinement in a box, without food, during a period exceeding two years and two months: a living individual exhibited by Dr. Stearns at a meeting of the California Academy of Sciences in I 875 was stated to be one of nine which had been collected in Lower California in March, I873, kept in a box undisturbed till June, I 875, and then revived in a jar containing some vegetable food and a small quantity of tepid water; subsequently, however, all had died, except the one exhibited, which, though not very active, seemed in pretty good health. ${ }^{2}$

1 J. S. Gaskoin, "Proc. Zool. Soc.," I 850, pp. 243-4: Woodward and Wollaston, "Ann. and Mag. Nat. Hist.", (2), vi. (1850), pp. 489-90; and see also Woodward's "Manual," ed 4, rep. I89o, p. 14 .

2 R. E. C. Stearns, "Am. Nat.," xi. (1877), Ioo; and "Proc. California Academy of Sciences," October 18th, 1875, as quoted in "Ann. and Mag. Nat. Hist.," (4), xix., pp. 355-6 and "Quart. Journ. Conch.,"i., p. 218. 
BUlinus ROSACEUS.-Four individuals of a large Bulimus from Valparaiso, as related by Sir C. Lyell in the "Principles," were brought to England by Lieutenant Graves, who accompanied Captain King in his expedition to the Straits of Magellan; they had been "packed up in a box, and enveloped in cotton, two for a space of thirteen, one for seventeen, and a fourth for upwards of twenty months," but, when exposed by Mr. Broderip to the warmth of a fire in London, and provided with tepid water, Lyell saw them revive and feed greedily on lettuce-leaves. B. rosaceus seems to be the species referred to, of which Captain King, in a paper on the Mollusca, etc., collected by the "officers of H.M.S. Adventure and Beagle employed between the years i 826 and I830 in surveying the southern coasts of South America including the Straits of Magalhaens and the coast of Tierra del Fuego," gives the following note:

"Soon after the return of the expedition, my friend, Mr. Broderip, to whose inspection Lieutenant Graves had submitted his collection, observing symptoms of life in some of the shells of this species, took means for reviving the inhabitants from their dormant state, and succeeded. After they had protruded their bodics, they were placed upon some green leaves, which they fastened upon and ate greedily. These animals had been in this state for seventecn or eighteen months, and five months subsequently another was found alive in my collection, so that this last had been nearly two years dormant. These shells were all sent to Mr. Loddige's nursery, 
where they lived for eight months, when they . . . all died within a few days of each other."

Bulimus EREMITA.-A specimen of this snail, from Turkestan, said to have been kept dry for two and a half years, revived and ate, but died after three or four days. ${ }^{2}$

Pupa tridens and Clausilia Rugosa.-Some snails, apparently belonging to these species, collected in France and close-packed in a pill-box by $\mathrm{Mr}$. John Curtis in July, I 830 , and subsequently kept in a dry place without food for nine months, on being placed on wet moss were seen to revive within twenty-four hours. ${ }^{3}$

Operculate SNAils.-The Cyclostomas, according to a statement in Woodward's "Manual," + are well known to be able to survive imprisonments of many months. Some foreign species, procured by Mr. Pickering from a dealer, and kept by him for some weeks, are said to have revived in water. ${ }^{5}$ Numerous examples of $C$. articulatum, collected in February, 1858, by Madame Ida Pfeiffer, in the Island of Rodriguez, and conveyed from thence to Mauritius, continued active, without taking food, during a stay there of two

1 Lyell, "Principles," ii. (1875), p. 377 ; P. P. King, "Zoological Journal," v. (1835), p. 342.

"Goldfuss, as quoted in the "Zoological Record," xxi. (1884), Moll., p. 19.

3 J. Curtis, "Trans. Lin. Soc.," xvi. (1833), 766.7.

4 Ed. 4, rep. 1890 , p. I4.

s. P. Woodward, "Ann, and Mag. Nat. Hist.," (2), vi. (1850), 489.90. 
months, and three individuals remained alive after the voyage to England, which occupied ten weeks. They were hrought over, packed in paper and rags, in a tin box with a lid, and were not taken out until a fortnight after their arrival. One lived for some months under a bell-glass with moss and ferns. ${ }^{1}$ A specimen of Rhaphoulus chrysalis, collected in the month of January by Captain R. H. Sankey, remained closed in its shell until 27 th of June, when it yielded slowly to the means $\mathrm{cm}$. ployed to revive it, finally moving about and creeping freely under an inverted glass. Cyclophorus indicus, from Bombay, was once received by Mr. Benson in a living state, after a voyage round the Cape, occupying four months. ${ }^{2}$ According to a statement by Mr. John Curtis in I $33 \mathrm{I}$, operculate molluscs have been reanimated after having remained dormant in cabinets for very long pcriods, "it has been said for forty years" ! 3

1 S. P. Woodward, "Ann. and Mag. Nat. Hist.," (3), iv. (1859), 320.

2 IV. H. Benson (on R. chrysalis and C. indicus), "Ann. and Mag. Nat. Hist.," (3), iv. (1859), 93-4.

s J. Curtis, "Trans. Lin. Soc.," xvi. (1833), 766-7. 


\section{CHAPTER VI.}

\section{MEANS OF DISPERSAL.}

A CLUE to the almost universal distribution of many families and genera of land-shells is to be found, Mr. Wallace observes, in their immense antiquity: in the Pliocene and Miocene formations, he says, most of the remains of these creatures are either identical with or closely allied to living species, while even in the Eocene almost all are of living genera; no true landshells have been found in the Secondary formations, but they must certainly have abounded, for in the far more ancient Palæozoic coal measures of Nova Scotia two species of the living genera $P u p a$ and Zonites have been discovered in considerable abundance. Types having thus "survived all the revolutions the earth has undergone since Palæozoic timës," are hardly likely to be confined by now existing arms of the sea, mountain chains, and other similar barriers which have effectually limited the ranges of many groups of higher animals. ${ }^{1}$ But it is obvious, of course, that antiquity in itself, however great, could have effected nothing without migra-

1 "Geographical Distribution," ii. p. 528; "Island Life," pp. $76-7$, ed. 2, p. 79. 
tion and dispersal: With the great age of the genera and higher groups in view, however, and admitting that the creatures are able to migrate on land, even with extreme slowness, and that they possess some means, however rarely occurring, of crossing the sea, we need hardly feel surprise at their having spread into all lands ever connected with continents, and even into the most remote and isolated islands of the open ocean. ${ }^{1}$

Something no doubt is to be attributed to unaided or voluntary migration over land by gradual progression generation after generation, for, as Mr. Wallace states, there is a natural tendency among animals to roam in every direction in search of fresh pastures ${ }^{2}$ but snails are proverbially slow, and their powers of voluntary dispersal, therefore, must necessarily be very limited. ${ }^{3}$ It appears, however, that they are in a better position in this respect than fresh-water kinds, many of which, more especially the bivalves, (as far as their own powers are concerned) seem to be more or less completely restrained within the limits of the river-basin in which they happen to live. Dr. Binney has remarked that snails are not instinctively restricted to particular local habitations, having no regular places of breeding or of shelter, and this, he thought, would favour their diffusion, but it seems, from observations which have been made since he wrote, that certain kinds return from time to

'See "Geographical Distribution," ii. p. 526, \&c.; "Island Life," p. 77.

2 "Geographical Distribution," i. p. Io.

3 "Island Life," p. 76. 
time to fixed resting places or homes, and probably many possess the same habit; ${ }^{1}$ it is doubtless true, however, as Binney argued, that-although no individual can have made any considerable progress-a species in the course of the countless generations which have existed may have wandered to vast distances from its original birth-place." Vast changes of climate, it will be remembered, have occurred from time to time, and, as Mr. Darwin has remarked, a region now impassable owing to the nature of its climate may have been "a high-road for migration when the climate was different." It will be remembered also that a great many changes in the relative positions of land and sea have certainly taken place during the existence of living genera, so that uninterrupted highways may once have existed where arms of the sea now absolutely preclude unaided migration: Forbes held indeed, as Darwin puts it, that "all the islands in the Atlantic must have been recently connected with Europe or Africa, and Europe likewise with America," and other authors, it is said, "have thus hypothetically bridged over every occan, and united almost every island to some mainland;" it is certain, however, that the cnormous geographical changes here implicd have never really occurred during the period of recent organisms, but geologists are agreed that great mutations of level have taken place within this period,

'On the "Faculty of homing in Gastropods," sce "Naturalist," 1890, pp. 307-18.

'A. Binney, "Terrestrial air-breathing Mollusks," i. (1851), p. 105 . 
and no doubt, as Mr. Wallace remarks, the general stability of continents and occans has been accompanied by constant changes of form. ${ }^{1} \quad$ The building up of great continental extensions for the purpose of explaining facts in distribution, as Mr. Darwin more than once observed, has doubtless tended to check the investigation and study of means of dispersal, and has been an ill-service to science."

It scems to have been supposed by some writers that voluntary migration is the only means of dispersal possessed by these creatures, but in view of the facts connected with their distribution referred to in the last chapter we are bound to admit that they have been carried, occasionally at least, from one place to another, even over considerable expanses of ocean, unless indeed, we fall back upon imaginary extensions of land, or take for granted-as Recve did-_" "the doctrine of a plurality of progenitors for each species." We are confronted at once, however, with a statement by $\mathrm{Mr}$. Wallace (repeated as recently as i 887 by Professor

1 “Origin," p. 323 ; "Island Life," p. 502, ed. 2, p. 534.

"See letters to Lyell and Hooker, I856, "Life and Letters," ii. ( 888 ), pp.78-82 ; and see also Wallace, "Island Life," p. Io, ed. 2 , same page: "If we once admit that continents and oceans may have changed places over and over again (as many writers maintain), we lose all power of reasoning on the migrations of ancestral forms of life, and are at the mercy of every wild theorist who chooses to imagine the former existence of a now-submerged continent to explain the existing distribution of a group of frogs or a genus of beetles."

3 "Land and fresh-water Mollusks," 1863, p. 254. 
Heilprin) that the exact mode in which the diffusion of the creatures has been effected is not known. ${ }^{1}$ It seems probable, however, from many considerations, that they are carried from place to place by accidental or occasional means of various kinds similar in many respects to those which we have seen have almost certainly operated for the dispersal of the fresh-water groups, yet the very general absence of evidence on the point is certainly surprising: hitherto, as Sir C. Lyell remarked in the "Principles," "the naturalist has not witnessed the arrival of a new continental Helix on any remote oceanic island, except by the aid of man," " and, indeed, it may be said that we have little or no actual evidence of precise modes of dispersal even for short distances on land. We shall probably find reason to believe, however, that transportal through wide spaces is by no means so rare as might at first sight have been supposed, but the ultimate establishment of a colony in a new home, which will always depend on many complex contingencies and must often be altogether impossible, is quite another matter; and it should be clearly understood that the colonization of a species on an oceanic island, or at any other distant point, as the result of the trans-oceanic dispersal of a few individuals, must certainly be extremely rare and exceptional, and is hardly likely to happen more than once, perhaps,

1 "Geographical Distribution," ii. p. 525; Heilprin, "Geo. graphical and Geological Distribution of Animals," I887, p. 53.

" "Principles," ii. p. 434 
in the course of many thousands of years. I have collected a few notes on various suggested means of distribution, but, as Darwin and A. de Candolle agreed, ${ }^{1}$ the putting together of merely possible means is poor work; nothing more can be done at present, however, and we are not likely to obtain much in the way of direct evidence until some traveller-naturalist gives his whole attention to the subject, and carries on a series of careful investigations.

\section{OCEAN CURRENTS.}

Professor Semper regarded the currents of the ocean as beyond doubt the most important means of transportal for land mollusca; indeed, according to this author, it is "more than probable that land-snails can travel only in this way, and in no other, from one island to another." ${ }^{2}$ But it will be remembered that Mr. Darwin concluded that the creatures are not likely to be often thus transported, for, as stated in the "Origin," they are known to be easily killed by scawater, and their eggs, at least such as were tricd, sank in it and were killed; it was found by experiment, however, that when hibernating and having a membranous cpiphragm over the mouth of the shell, several species were able to withstand immersion for scven days :

"One shell, the Helix pomatia, after having been thus

${ }^{1}$ See "Life and Letters," ii. (1 888), p. 82.

2 K. Semper, "Animal Life," ed. 4, (I890), pp. 282, 296, 3 I 4. 
treated and again hibernating, was put into sea-water for twenty days, and perfectly recovered. During this length of time the shell might have been carried by a marine current of average swiftness to a distance of 660 geographical miles. As this Helix has a thick calcareous operculum [or epiphragm], I removed it, and when it had formed a new membranous one, I again immersed it for fourteen days in sea-water, and again it recovered and crawled away. Baron Aucapitaine has since tricd similar experiments; he placed roo landshells, belonging to ten species, in a box pierced with holes, and immersed it for a fortnight in the sea. Out of the hundred shells, twenty-seven recovered. The presence of an operculum seems to have been of importance, as out of twelve specimens of Cyclostoma elegans, which is thus furnished, eleven revived. It is remarkable, seeing how well the Helix pomatia resisted with me the salt-water, that not one of fifty-four specimens belonging to four other species of Helix tried by Aucapitaine, recovered." "

It is suggested that the creatures are likely to be carried by currents while hiding in chinks of drift-timber, and more rarely with icebergs, in the interstices of floating pumice, etc. ; thus situated they may sometimes be protected, or partially protected, for a time from contact with sea-water, and may possibly be safely carried during calm weather to great distances, so that the arrival of shells, still alive, on the shores of a foreign country or distant

$$
1 \text { "Origin," p. } 353 .
$$


island may not be a very rare event. It cannot be supposed for a moment, however, that they will often be landed in spots suitable for the establishment of new colonies, for drift-timber, etc., is only likely to be thrown well out of the reach of high tides by violent storms. Even when this happens it is quite likely that an immigrant would be picked up at once by some hungry bird, or it might find the soil, the climate, or the food-stuffs altogether unsuitable, and even if it survived and bred for a time, it might be unable ultimately to compete with the molluscs already inhabiting the spot, or to withstand the attacks of new enemies surrounding it. Even under the most favourable conditions a few imported individuals would very likely lose sight of each other, and die, consequently, without leaving offspring; and this fate would surely happen to solitary specimens, unless they chanced to contain fertile ova. Occasionally, however, in the course of ages, colonies have almost certainly been thus established, perhaps by solitary individuals. The facts above referred to concerning the production of fertile eggs by snails which had long remained dormant are of interest in this connection; one can well imagine, for instance, that the thirty "points" with which the solitary Helix observed by Mr. Gaskoin became surrounded might have founded a colony at some distant place, even if the accidents leading to the transportal of the parent had obliged it to remain without food, in a torpid state, for a long period, provided of course that the offspring of the same parent can multiply inter se. It will be 
remembered that time, independently of fresh transportals, will have tended to increase the richness of insular faunas, for in the course of vast ages the descendants of originally introduced forms will generally have divided up into distinct varieties, and ultimately in many cases into distinct species and genera ; indeed, if such were not the case, we should almost have to believe in the special creation for occanic islands of the endemic types which enter so largely into their faunas.

Icebergs "covered with an alluvial soil, on which pine-saplings and a variety of herbaceous plants are seen growing," according to Sir C. Lyell, are sometimes drifted with the currents or blown along by the winds in the arctic seas, and, Mr. Darwin says, they are "sometimes loaded with earth and stones, and have even carried brushwood, bones, and the nest of a land bird," so that it scems just possible that terrestrial molluscs or their ova may have been thus carried-though perhaps very rarely-more especially during times when ice extended over the now temperate regions, and the safe landing of such creatures at some more or less distant point, though certainly happening only with extreme rarity, is perhaps not quite impossible. It has been remarked, however, in a work edited by Dr. R. Brown," that it "scems like straining a point" to class ice as one of "the agents concerned in the dispersal of plants, insects, molluscs, etc." Icebergs, according to this work, do not carry nearly so much débris as

1 "Principles," ii. p. 394; "Origin," p. 328.

2 "Our Earth and its Story" (Cassell: no date), ii. p. 310. 
is popularly supposed; and before having travelled far the "raft" is sure to be lashed by the waves, or melted at the base by warmer water or by the wear and tear of its motion through the sea; "pieces will calve or break off, and before long the berg will capsize, owing to its being top-heavy, and the whole burden it bears be tumbled into the sea;" in like manner, it is stated, icefields, too, will break in pieces and discharge their loads. Referring more especially to the dispersal of seeds, it is also remarked that "the only possible chance a seed carried by ice has to germinate in a new situation is when the ice grounds on a low islet, or is dashed on a lee shore by the action of the winds-an event which rarely happens. Even when stranded on a low shore it cannot approach near enough for its burden to be thrown on land, as a low-lying coast has shallow water off it; or if deep off shore the cliffs are in gencral high, so that this amounts to the same thing." Seeds or fruits, it might be remarked, when ultimately washed upon the strand by the waves, might be picked up and carried inland by birds, for some are well known to pass the intestines unhurt; but shells, similarly washed up in a living state, if swallowed by birds, would generally be killed and digested.

Floating pumice-stone, from its porous and spongelike texture, Mr. Bates and Sir C. Lyell have pointed out, seems likely to be a vehicle for the transport of the eggs of various animals, both terrestrial and aquatic. According to Mr. Bates, pieces have been seen floating on the surface of the main current of the 
Amazons, twelve hundred miles from the volcanoes of the Andes from which they must have come; he once received a large piece which had been found in the middle of the stream about 900 miles further down, and pieces having reached this distance, he remarks, would be pretty sure of being carried out to sea, and thence probably with the north-westerly Atlantic current to shores many thousands of miles away. From the rounded and water-worn appearance of the fragments, it was concluded that they must have been rolled about for a long time in the shallow streams near the sources of the rivers at the feet of the volcanoes before they leapt the waterfalls and embarked on the currents leading direct for the Amazons, and "they may have been originally cast on the land and afterwards carried to the rivers by freshets, in which case the eggs and seeds of land-insects and -plants might be accidentally introduced, and safely enclosed with particles of earth in their cavities." It seems very likely also that the eggs of molluscs and small snails in a state of hibernation may sometimes be thus enclosed, and as the speed of the current, in the Amazons, for instance, during the rainyseason, is said to be from three to five miles an hour, they might thus travel, unharmed, on fresh-water to great distances, and might possibly survive for some days on the surface of the ocean. I am not aware, however, that snails or their eggs have ever been found in the interstices of pumice. It was not until after his return to England that Mr. Bates came to regard the fragments he had seen as probable agents for dispersal, and he 
then much regretted having neglected, whilst on the spot, the opportunity of ascertaining whether they contained organisms of any kind.' Pumice is occasionally washed up on the shores of many islands, and vessels have encountered vast quantities on the ocean, but it may often be derived from volcanoes quite near the sea, or from submarine ones.

Trees are carried out to sea by rivers in vast numbers, and being often drifted by occan-currents to great distances, are occasionally thrown up on foreign shores, even, as Mr. Darwin states, on those of islands in the midst of the widest oceans, ${ }^{2}$ and land-snails of many kinds, conccaling themselves under the bark and within the trunks of old and hollow trees or living among the earth and débris at their roots, or depositing their eggs in such situations, must almost certainly be carried with such drift-wood with some frequency. Volumes might probably be filled with accounts of the floating of timber, etc., upon the sea and its stranding on more or less distant coasts; most naturalists are familiar with such facts; it may perhaps be useful, however, to refer briefly to one or two observations on the point. At a great distance from the coast of New Guinea, about seventy miles north-east of Point D'Urville, where the great Ambernoh River runs into the sea, the Challenger, as Mr. Moseley states, found the water blocked with drift-wood, disposed in long curved

${ }^{1}$ H. W. Bates, "Naturalist on the River Amazons," ed. 5, I884, pp. 247-9; see also "Principles," ii. p. 379.

" "Origin," p. 326. 
lines at right angles to the direction in which the river's mouth lay, and the screw had to be constantly stopped for fear it should be fouled. Most of the pieces-which did not appear to have been very long in the sea-were of small wood, branches and small stems; among them, however, were many whole up-rooted trees. As the ship was nearing Dobbo, the port of the Aru Islands, large quantities of leaves, fruits, etc., and branches of trees were encountered, drifting about mingled with a floating seaweed, and off Ke Islands, and also among the Moluccas, similar drifts of land vegetation were met with. The sea-birds, especially terns, Mr. Moseley says, habitually resort to floating logs as resting places, and it is curious to see them in the distance appearing as if standing on the surface of the water, the logs themselves being often invisible.' Dr. Binney states that he once saw Nantasket beach, at the mouth of Boston harbour, strewn with logs, "driven from the rivers of Maine by easterly winds of several days' continuance," and he refers also to the frequent stranding of trunks of trees, fragments of wood, seed-vessels, and numerous other objects, some of unascertained origin, and others from the Spanish Main, Cuba, etc., on the shore of Key West, and on the beach of Cape Florida and the shores and islands to the north of it. ${ }^{2}$ Mr. C. T. Simpson mentions having seen, in sheltered caves on the island of Utilla,

1 H. N. Moseley, "Notes by a Naturalist on the Challenger," 1879, pp. 367, 432-4.

2 A. Binney, "Terrestrial air-breathiug Mollusks," i. (1851), pp. $153,157$. 
etc., and on the shores of Florida, large numbers of stranded trees, some submerged all but a few branches, others at the tide line, and others thrown high and dry by storms out of the reach of the sea at ordinary times. ${ }^{1}$ Dr. Alford Nicholls, of Dominica, when in Tobago in I89I, saw large trunks of trees stranded along the coast; they had evidently come from the Orinoco, and many of them had the bark and some of the branches still attached. In the Radack Archipelago, situate in the western part of the Pacific, as mentioned in the Beagle Journal, palms and bamboos, from somewhere in the torrid zone, and trunks of northern firs, are known to have been washed on shore, the latter, it is remarked, having necessarily come from an immense distance. Drift-wood, bamboos, and canes, according to Captain Collnett, are often washed on the south-eastern shores of the islands of the Galapagos Archipelago. At the Keeling or Cocos Islands, in the Indian Ocean, trunks of the sago-palm, and large masses of Java-teak and yellow-wood, the blue gum-wood of New Holland, and immense trees of red and white cedar, etc., are said to have been washed up; fishing-canoes, also, apparently from Java, have come ashore at times. ${ }^{2}$ A South Sea islander's canoe, Mr. Musson tells me, was once thrown up on Curtis Island, Queensland. Vast

1 C. T. Simpson, "Conchologists' Exchange," ii. ( 1887 ), p. 38.

${ }^{2}$ Darwin's Beagle Jourzal, ed. 2, I 845, pp. 392 and 454-5, quoting Chamisso, on the Radack Archipelago; Collnett, on the Galapagos group: and Keating ("Holman's Travels"), on the Keeling or Cocos Islands. 
quantities of carth, etc., are sometimes carricd away upon the roots of trees by large tropical rivers, where, also, floating rafts or islands, often of considerable sizc, are frequently formed, and occasionally carricd out to sca, to be drifted, perhaps, during calm weather, to great distances. Sir C. Lycll collected some very interesting notes on this subject, which $J$ give in his own words:

"Within the tropics . . . there are floating islets of matted trees, which are often bornc along through considerable spaces. These are sometimes scen sailing at the distance of fifty or one hundred miles from the mouth of the Ganges, with living trees standing erect upon them. The Amazon, the Congo, and the Orinoco, also produce these verdant rafts, [which are formed of accumulations of floating trees, arrested in their progress by snags, islands, shoals, or other obstructions, as had becn] already described when speaking of the great raft of the Atchafalaya, an arm of the Mississippi, where a natural bridge of timber, ten miles long, and more than two hundred yards wide, cxisted for more than forty ycars, supporting a luxuriant vegetation, and rising and sinking with the water which flowed beneath it.

"On these green islets of the Mississippi, obscrves Malte-Brun, young trees take root, and the pistia and nuphar display their yellow flowers: serpents, birds, and the cayman alligator, come to repose there, and all are sometimes carried to the sca, and engulphed in its waters. "Spix and Martius relate that, during their travels in brazil, they were exposed to great danger while ascend- 
ing the Amazon in a canoe, from the vast quantity of drift-wood constantly propelled against them by the current; so much so, that their safety depended on the crew being always on the alert to turn aside the trunks of trees with long poles. The tops alone of some of the trees appeared above water, others had their roots attached to them with so much soil that they might be compared to floating islets. On these, say the travellers, we saw some very singular assemblages of animals, pursuing peacefully their uncertain way in strange companionship. On one raft were several grave-looking storks, perched by the side of a party of monkeys, who made comical gestures, and burst into loud cries on seeing the canoe. On another was seen a number of ducks and divers, sitting by a group of squirrels. Next came down, upon the stem of a large rotten cedar tree, an enormous crocodile, by the side of a tiger-cat, both animals regarding each other with hostility and mistrust, but the saurian being evidently most at his ease, as conscious of his superior strength.

"Similar green rafts, principally composed of canes and brushwood, are called 'camelotes' on the Parana in South America; and they are occasionally carried down by inundations, bearing on them the tiger, cayman, squirrels, and other quadrupeds, which are said to be always terror-stricken on their floating habitation. No less than four tigers (pumas) were landed in this manner in one night at Monte Video, lat. $35^{\circ} \mathrm{S}$, to the great alarm of the inhabitants, who found them prowling about the streets in the morning. 
"In a memoir lately published, a naval officer relates that, as he returned from China by the eastern passage, he fell in, among the Moluccas, with several small floating islands of this kind, covered with mangrove trees interwoven with underwood. The trees and shrubs retained their verdure, receiving nourishment from a stratum of soil which formed a white beach round the margin of each raft, where it was exposed to the washing of the waves and the rays of the sun. The occurrence of soil in such situations may easily be explained; for all the natural bridges of timber which occasionally connect the islands of the Ganges, Mississippi, and other rivers, with their banks, are exposed to floods of water, densely charged with sediment.

"Captain W. H. Smyth informs me, that, when cruising in the Commallis amidst the Philippine Islands, he has more than once seen, after those dreadful hurricanes called typhoons, floating masses of wood, with trees growing upon them; and ships have sometimes been in imminent peril, as often as these islands were mistaken for terra firma, when, in fact, they were in rapid motion.

"It is highly interesting to trace, in imagination, the effects of the passage of these rafts from the mouth of a large river to some archipelago, such as those in the South Pacific, raised from the decp, in comparatively modern times, by the operations of the volcano and the earthquake, and the joint labours of coral-animals and testacea. If a storm arise, and the frail vessel be wrecked, still many a bird and insect may succeed in 
gaining, by flight, some island of the newly-formed group, while the seeds and berries of heribs and shrubs, which fall into the waves, may be thrown upon the strand. But if the surface of the deep be calm, and the rafts are carried along by a current, or wafted by some slight breath of air fanning the foliage of the green trees, it may arrive, after a passage of several weeks, at the bay of an island, into which its plants and animals may be poured out as from an ark, and thus a colony of several hundred new species may at once be naturalized." 1

Many kinds of snails, from the nature of their habitats, scem eminently liable to be carried with floating trees, rafts, etc. Large numbers, every one knows, hide themselves beneath the bark of trees; the Succinea arborea, to give an instance, lives, Mr. Musson tells me, on the inner side of the bark of gum-trees in Australia, and is difficult to remove without breaking the shell; and several of our own snails-Clausilice, etc.-as every conchologist knows, are often found in similar situations, under the bark of old forest trees. Crevices within the trunks of partially hollow trees are also favourite hiding places for many kinds, and some are in the habit of eating their way far into the decaying wood. The Rev. L. Blomefield has described a pollard-clm pierced in all

1 "Principles," cd. 9, I853, pp. 640-2, quoting "Systcm of Gcography," vol. v. p. 157 ; Spix and Martius, "Reise, etc.," vol. iii. pp. 1011, IOI3; Sir W. Parish's "Buenos Ayres," p. 187; Robertson's "Letters on Paraguay," p. 220 ; and "Unitcd Service Journal," No. xxiv. p. 697. 
directions by rock-snails (Helix lapicida), great numbers of which, of various sizes, were cxposed to vicw when the bark and portions of the wood were torn away.' Species in no sense arboreal may often take up their abode in chinks in logs which happen to be lying on the ground on the banks of water-courses, and which of course are liable to be drifted off during floods. Strictly ground species may occasionally be carricd, in numbers, in the earth, etc., at the roots of trecs. It seems probable also that many may be transported with miscellaneous vegetable débris, cocoanut-husks, ctc., which must often be swept from the ground and carried away to considerable distances, but snails travelling in this way would be much exposed to the evil influences of salt water. A few shells (one of which was alive) of Helix anmulus-a species discovered during the Chevert Expedition near the mouth of Katow River, New Guinca-were found, about forty miles south from Katow, at Dungeness Island, Torres' Straits, to which place they are likely to have been carried, Mr. Brazicr thinks, on the "drift-timber and palm roots which are to be scen floating in the Straits after the north-west monsoons: " the species lives, in the original locality, "in clusters inside of old cocoa-husks," and these also, it would seem probable, may have served as vehicles for its transportal. Mr. Liardet has remarked that the numerous small terrestrial shells

L. Jenyns (now Blomefield), "Observations in Natural History," p. 321, as quoted in the "\%oologist." (3), x. (1886), 452-3.

"J. Brazier, "Proc. Lin. Soc., N.S.W.." i. (1877), 100. 
inhabiting the coast-lands of the Fiji group, and common to most of the islands, living as they do, "sheltered by bark on logs, and in the decaying husks of old cocoanuts," are probably frequently transported from island to island.' As indicating a possibility of actual transplantation by means of agencies of the present kind, it is interesting to note that drifted trees are known to be occasionally left by storms on island or foreign coasts, high and dry, out of the reach of the ordinary tides. Mr. C. T. Simpson, as just quoted, states that he has seen trees thus stranded on the island of Utilla, and on the shores of Florida. Charles Goodridge, who stayed some time in the Crozet Islands in $\mathrm{I} S 2 \mathrm{I}-3$, described the discovery of several tree-trunks, lying on the ground as if thrown up by the sea, more than a mile from the reach of the tides. The wood was evidently not fossil, and "Goodridge concluded that it was drift-wood thrown up so far during some volcanic convulsion." " It will always be remembered, of course, that complete protection from sea-water during long periods will hardly ever be afforded by floating timber, and thousands of inland molluses must annually perish in the sea; partial protection, however, both for adult animals and ova, must often be afforded for a considerable time, and some snails, as we have seen, can withstand total immersion for short periods. Trees,

1 E. A. Liardet, "Proc. Zool. Soc.," I \$76, p. 99.

${ }^{2}$ C. M. Goodridge, "Narrative of a Voyage to the South Seas, etc.," pp. 42-3, as quoted by Mr. Moseley, "Naturalist on the Challenger," I 879, pp. 182-3. 
especially if loaded with stones, etc., as Mr. Darwin has remarked, scem likely in many cases to float beneath the surface. In the channels of Tierra del Fuego large quantitics of drift-timber are cast upon the beach, yet it is cxtremely rare to mect a log swimming on the water.' Even in the case of timber which floats upon the surface the water will gradually penctrate every crevice, and most trees are almost sure to lose their bark before long ; the bark of those seen by Mr. Moscley off the coast of New Guinca was often detached, floating separately, and much wood was held vertically in the water; but on the other hand, as we have just seen, many of the trec-trunks evidently from the Orinoco, observed by Dr. Nicholls on the coast of Tobago had the bark still attached. The pollard.elm described by Mr. Blomefield is said to have been so weakened by the attacks of Helix lapicida that a slight wind might have overturned it, and one can well imagine that such a trec, after having fallen to the ground, might casily be swept off by the sudden overflow of a river, and the snails contained within it, if "in a torpid state" with the mouths of their shells stopped up "with a bung of sawdust and small chips of wood cemented together," as was the case with some of those in the tree in question, would be well fitted to resist salt water, but a tree of this kind when launched upon the waves would almost immediately become sodden and fall to pieces. Immense numbers of land snails, especially of kinds frequenting damp places

1 Jarwin's Journal, ed. 2, 18+5, p. 462. 
and river margins, might possibly be carried with floating islands or rafts, but it is obvious, of course, that the landing of objects of this kind on foreign shores in such a manner as to enable slow-moving terrestrial creatures to disembark must be very rare indeed, yet such occurrences, as Lyell maintained, notwithstanding their extreme rarity, may possibly account "in tropical countries for the extension of some species of mammalia, birds, insects, land-shells, and plants to lands which without such aid they could never have reached." ' Professor Semper has remarked that large land-shells, and such as live in the highest branches of trees and lay their eggs there, like all the species of Cochlostyla, will obviously be far more difficult to transport than small species which can creep into rifts in trees or between the roots; and species belonging to groups, which (like Helix similaris) live on the ground among stones and earth, will, he observes, be almost as well protected during a sea voyage as the operculate kinds. This he shows is in harmony with certain known facts in distribution, most of the small species and of the operculate species having a much wider range than the large inoperculate forms. In the Philippines the typical genera (or sub-genera) Cochlostyla, Rhysote, Chlorac, and Obbina, which principally live on trees, are almost confined to that group of islands, while the small genera, as Subulina, Trochomortha, and Ennea, among the Helicidx, and the operculate genera Cyclo- 
phoms, Alycaus, Helicina, and Diplommatina, have a very wide distribution.' It seems probable, however, that large arboreal snails, even those which live in the highest branches, may possibly be carried from place to place when several trees are drifted off together in the form of a floating islet. Some kinds adhere firmly to the branches when hibernating, and others shelter themselves among the epiphytic vegetation. Bulimus frescirtus, a large species which lives on the branches of trees, attaches the mouth of the shell very strongly to the bark by means of a thick opaque secretion which hardens to the consistency of gluc, and in tearing the animal away the bark or the shell is fractured sooner than the secretion. Bulimus undatus, also, another large arboreal snail, attaches itself by means of a similar glutinous substance, which, though exposed to wind and rain, forms a perfect adhesion and protection to the animal and only yields to its own solvent powers on the approach of spring. These, and other species with similar habits, may almost certainly, as already suggested by Mr. Simpson, be carried in safety over the sea on floating trees the higher branches of which are borne above the crest of the waves, and it even seems likely that they may float safely for moderate distances in the sea itself adhering to detached branches, etc. Both the specics above mentioned are enumerated by Dr. Binney among shells believed by him to have been introduced by currents from Cuba to the southern part 
of the peninsula of Florida and the adjacent islands: Mr. W. G. Binney, however, writing of B. undatus, has suggested that the creature may have been a widely distributed species of an ancient fauna, which has survived at various points around the gulf of Mexico.' Unfortunately I do not know that any observation clearly indicating the transportal of molluscs, or their eggs, with drift-timber, etc., has ever been made. The creatures have never been found, as far as I have ascertained, in the crevices or under the bark either of trees encountered upon the sea, or of those stranded on foreign coasts. Important discoveries may possibly be made, however, by some traveller who applies himself to the careful examination of a large number of such trees. Mr. Layard tells me that landing on one occasion on "a lone, sandy island in the Indian Ocean, north of Madagascar," he found on the shore a huge tree-trunk, "just arrived from the African Coast," swarming with ants, and containing in a crevice the living eggs of a lizard, probably a gecko!

\section{RIVERS AND FLOODS.}

No doubt, as Mr. Wallace observes, terrestrial molluscs have been "widely scattered over land areas" by "large rivers and occasional floods." " From considerations above referred to it is obvious, of course, that both adults

${ }^{1}$ A. Binney, "Terrestrial air-breathing Mollusks," i. (1851), p. I53; ii. (1851), pp. 270, 274 ; W. G. Binney, v. (1878), p. 409 ; C. T. Simpson, "Conchologists' Exchange," ii. ( 1887 ), p. 38.

" "Geographical Distribution," ii. p. 525. 
and ova must often be carried down stream, sometimes to great distances, along with floating timber, vegetable débris of many kinds, pumice, \&c., which must frequently be stranded on the low and shelving banks of river-margins and on islands in mid-stream, but I do not know that we liave any actual evidence of dispersal in this way. The landing of a tree in a condition similar to that of the pollard-elm above mentioned, however, would certainly be sufficient to account for the presence say of Helix lapicida-quite unknown perhaps in the surrounding neighbourhood-on some such island or river-bank, for a whole colony of snails, possibly from a locality several miles distant, might thus be safely landed in a new home. Dr. R. Brown (or some author edited by him), ${ }^{1}$ mentions having seen, on his way up some American river, the huge trunk of a tree "floating leisurely down stream with plants blooming on its decayed surface," and weeks afterwards, on coming down the river, he has noticed, as he assures us, the same tree "left high and dry on the banks, with the same plants, still in flower or in seed, growing upon it." The pumice-stones floated down by the Amazons, as Mr. Bates states, are sometimes stranded on the banks in different parts of the river." Many of the smaller snails may frequently be floated in the hollow stems, or kexes, of large umbelliferous plants, for these, often lying loosely upon the ground, are liable to be swept away by floods, and molluscs are known to hide

"See "Our Earth and its Story," (Cassell : no date), p. 306.

"Naturalist on the River Amazons," ed. 5, 1984 , p. 248. 
within them in winter-time: Vertigo edentula, for instance, as Mr. Jeffreys mentions, is then to be found in such stems, together with Carychium minimm, and other minute shells. ${ }^{1}$ Thus concealed, the creatures would be buoyed up and protected in some degree from contact with the water. It secms probable also that entirely unprotected individuals, when swept from riverbanks during floods, or chancing to fall into the water at ordinary times, might occasionally be carried in safety to considerable distances, for they sometimes float on the surface and are never immediately drowned. Kinds which I have tried" have generally floated when the animal was extended from the shell. A specimen of Helix aspersa, in this condition, for instance, thrown into the river Lud, floated freely with the current, but I soon lost sight of it. Fiftecn specimens of $H$. hortensis, with the animals fully extended, all floated. The creatures sink, however, as a rule, if tried when the animal is entirely withdrawn; thus, of ten specimens of H. rufescens, all sank with the exception of two in which the animals were extended, and these, tried again when they had retired into their shells, sank also. But this is not invariably the case: of thirteen specimens of $H$.hortensis, for instance, placed in water when the

1 "British Conchology," i. ( I S62), pp. xxxiv., 269, 30r ; and see J. E. Harting, "Zoologist," (3), ii. (1878), 125. In gardens near Sydney, Mr. Musson tells me, Melix asperse often takes up its abode in the hollows of cut bamboos.

"Ilelit aspersu, hortensis, arbustorm, rufescens, \&c.; freshly' collected specimens for the most part. 
animals were within the shells, four floated. An individual of $H$. asperse in the same condition, and having the mouth closed with an epiphragm, also floated; and it is worth noting, perhaps, that when left in water for four hours, though it slightly forced the protecting epiphragm, it did not extend its body. The reader will remember, of course, that individuals which from their weight could not be floated by slowly-flowing rivers in their ordinary action, might be carried to considerable distances by streams with powerful currents, and by the rushes of water which occasionally occur in many slower streams in times of flood. Prodigious numbers of shells are known to be carried down by rivers, and they are frequently collected from alluvium (as dead-shells) in great quantity. Very large numbers, for instance, some evidently from a great distance, were collected by Dr. Scharff in March and April, I879, after the subsidence of an over-flow of the river Garonne, comprising no less than I 48 specimens of Pupa muscomu, and 352 of Vertigo pygmea! ${ }^{1}$ I hoped to have found records of the discovery of living shells in such situations, but have not done so, and it is perhaps hardly likely that evidently rivercarricd individuals should often be noticed, for unless they happened to be in a state of hibernation they would be sure to crawl away almost immediately from the débris with which they were stranded. None of the specimens from the Garonne were seen to be alive, but 
Dr. Scharff tells me that he remembers having somewhere scen an account of the finding of Helix cricetorum alive in alluvium. In December, I $\$ S O, \mathrm{Mr}$. Ashford winnowed out from amongst broken reeds and grasses more than two thousand shells of the young of Succinea putris, which had been swept from their winter moorings on the vegetation bordering the Avon by a recent flood, and left in the meadows near Christchurch ; the greater part, if not all, however, it is said, had "fallen a prey to tiny but voracious larvæ, probably of the smaller colcopterous insects." 1

As instancing possible or probable results of rivertransportal we may advert to statements given by $\mathrm{Mr}$. W. G. Binney in the second supplement to his famous work, previously quoted, on the land-shells of the United States and adjacent territories. ${ }^{2}$ Helix strigosa, it is stated, a widely distributed Central Province group of forms, ranging to the westward to the Sierra Nevada and Cascade Mountains, passes the latter even to the Pacific Occan, but the author doubts whether it is "really an inhabitant of the Pacific Region," the specimens collected from time to time west of the Cascades in Washington Territory and Oregon being possibly " individuals brought down by the Columbia River from the east of the Cascades, or colonies descended from such." Mr. Hemphill, he states, first called his atten.

1 C. Ashford, "Journ. of Conch.," iii. (I88 I), pp. I95-6.

2 "Terrestrial air-breathing Mollusks," second supplement to vol.v., pp. 26-8, 32, 39 : Bulletin Museum of Comparative Zoology, Harvard College, vol. xiii. No. 2. 
tion to this explanation of the presence in the Pacific Province of Central Province species, in a letter, concerning $H$. strigosa, from which the following is an extract. The same considerations, according to $\mathrm{Mr}$. Binney, apply to Helix solitaria, the group of Helix mullani, and Helix ptychophora:

"The Cascade range of mountains in Oregon is, as you are aware, a continuation of the Sierra Nevada. It crosses the Columbia River between the Dalles and Portland, and continues its northerly course on the west side of the Columbia. Numerous spurs, however, break off from the main range, and pass north through East Oregon into Utah and Idaho. One of these spurs, called the Blue Mountains, shoots off the Cascades near Mount Hood, and runs nearly parallel with the Columbia, forming the eastern boundary of its valley, and is about forty miles from the river, and terminates about abreast of the mouth of Salmon River, Idaho, and on the south side of Snake River. On the north side of Snake River these mountains have local names, but are known by the general name of Bitter Roct Mountains. . . By tracing the course of Snake River and its tributaries you will see it drains the northern part of the great central basin, and when it cut its way through these mountains it very likely drained the great system of lakes that once covered a great part of this central basin. Now the mountain ranges in this portion, north-east, are the metropolis of strigosa so far as we know at present; and it is not improbable that many indiriduals, and quite likely whole colonies, 
of that species are sometimes carried into the streams by rains and floods, and are borne arvay on the avaters to. wards the Pacific Coast. Occasionally some of the specimens must find or make a lodgment along the banks of the streams, and if the conditions are favourable a colony will spring up and perhaps spread over the neighbourhood. The banks of the Columbia between the Dalles and the mouth of Snake River, a distance of one hundred and fifty miles, are destitute of timber, and are covered for several miles back with loose drifting sand, quite unfavourable to the existence and spread of land-shells. The locality where I found the variety castancus wars on the bank of the Columbian near Celilo, about fiftcen miles above the Dalles, on the cart side of the Cars. cades, but on the avest side of the Blue Mountrins. This colony must have sprung from specinnens brought down the stream by floods. At a subsequent visit it had disappeared... Very likely the original strigosa [the original specimen, so named, was found on or near the Pacific Coast] may have come from some colony planted in this way."

Obviously, as was remarked by the Rev. H. H. Higgins, animals can be carried by means of rivers to lower localities only; it is clear, of course, that lands bordering on the higher waters of a river can never be thus reached: ' it is almost equally clear, however, as the elder Binney observed, that "a species having by its own powers attained the summit of a range of moun-

${ }^{1}$ H. H. Higgins, "P'roc. Lit. and Philos. Soc., Liverpool," xxxvi. (I882), pp. xliv.-xlv. 
tains, may, when aided accidentally by the current of rivers, be very rapidly diffused through the country on the other side." I

Rivers, with their occasional floods, it can hardly be doubted, have largely helped to bring about the wide distribution now enjoyed by many organisms, or groups of organisms ; for ages, it will be remembered, they have becn constantly carrying objects of all kinds out to sea, thus bringing them under the influence of the oceanic currents.

\section{WIND.}

Mr. Wallace has suggested that the smaller landshells, and others in a young state, attached to leaves and twigs, may be carried long distances by storms and hurricanes, and doubtless their eggs, even those of large kinds, may occasionally be transported by these means,? but here again, as might be expected, nothing approaching actual proof can be given. The hurricanes of tropical regions, Sir C. Lyell observes, sweep along at the rate of ninety miles an hour, rooting up trees and throwing down buildings in their course, possibly carrying, as he remarks, "even the heavier fruits and secds over friths and seas of considerable width," 3 and

A. Binney, "Terrestrial air-breathing Mollusks," i. (I85I), p. I 3 I.

"Sce "Ceographical Distribution," ii. p. 525 ; "Island Life," p. 76, ed. 2, p. 78 .

" "Principles," ii. p. 392. 
it has been suggested 'that minute land-shells and other' animals may be carried, by similar means, across arms of the sea.

Dead leaves, which are frequently caught up and blown to distances, are often inhabited by small landshells: indeed, in order to procure specimens for the cabinet, some collectors take home quantities of leaves, from which, when dried, great numbers of shells are sometimes sorted out; Dr. Turton told Mr. Jeffreys, for instance, that he procured many specimens of Hclix py'smae by collecting a bagful of dead and rather moist leaves and afterwards spreading them on paper to dry. ${ }^{2}$ On Oak Island, Dr. Gould found Cochlicopa hubrica in such numbers that hundreds could be taken from the ground with a single fallen leaf, and, as the moisture evaporated, all, it is said, "disappeared beneath the leaves." 3 Only violent hurricanes, it will be remembered, are likely to carry away moist and decaying leaves, which are generally matted together and lie heavily one upon another, and it may be doubted, perhaps, whether shells are often very abundant among loose dry leaves which alone are likely to be blown about by wind-storms at ordinary times. In April, in Epping Forest, I collected a large number of little shells belonging to seven species-Hyalinia fulva, H. pura

1 "Our Earth and its Story," iii. (Cassell : no date), p. 40.

2 "British Conchology," i. (1862), pp. 223-4.

3 Dr. Gould, "Invertebrata of Massachusetts," as quoted by Reeve, "Land and fresh-water Mollusks," I863, p. 93, and see Bimney, "Terrestrial air-breathing Mollusks," i. (1851), I 39. 
¿. margaritacea, Helix aculeata, H. pygman, Vertigo substriata, $V$. edentula, and Carychium minimum-from moist leaves, chiefly those of beech and holly; but in the same locality, in September, when the weather was hot and dry, a carcful examination of four handfuls of leaves, which were quite dry and might have been carried away by a strong wind, yiclded only a solitary Vertigo; this, however, on being moistened, was found to be alive.

In Germany, according to Mr. Daniel, the Helix aculeata, travelling high up into trees, particularly the alder, reaches the ground in autumn on the falling leaves. Helix fusce, too, M. Bouchard-Chantereaux states, inhabits alders in the woods near Boulogne, hiding on the undersides of the leaves, and falling with them in September and October.' Snails with habits of this kind, obviously, might be carried to considerable distances when leaves, instead of falling directly to the ground, happen to be blown off during autumn gales.

Many small snails are so light that they could certainly never impede the flight of leaves to which they happened to be more or less securcly attached; twelve "mature specimens" of Vertigo milium, for instance, a species found gregariously under or among dea deaves, and measuring only four-fifths of a millimetre in length, are stated by Professor Adams to weigh less than sixtenths of a grain. ${ }^{2}$

1 "British Conchology," i. (1862), p. 176: and p. 206.

"A. Binney, "Terrestrial air-breathing Mollusks," ii. (1851), p. 338. 
It is perhaps worth while in this connection to notice an extraordinary fall of oak leaves, witnessed in I889, in Dumfriesshire, on a farm on which were only five trees (two ash and three larch); the following account of the occurrence, in the words of the observer, was published in Nature in I $890:^{\prime}$

"I was struck by a strange appearance in the atmosphere, which I at first mistook for a flock of birds, but as I saw them falling to the earth my curiosity was quickened. Fixing my eyes on one of the larger of them and running about a hundred yards up the hill until directly underncath, I awaited its arrival, when I found it to be an oak leaf. Looking upwards the air was thick with them, and as they descencied in an almost vertical direction, oscillating, and glittering in the sunshine, the spectacle was as beautiful as rare. The wind was from the north, blowing a very gentle breeze, and there were occasional showers of rain. On examination of the hills after the leaves had fallen, it was found that they covered a tract of about a mile wide and two miles long. The leaves were wholly those of the oak. No oak trees grow in clumps together nearer than eight miles. The aged shepherd, who has been on the farm since I 826 , never witnessed a similar occurrence."

Mr. Musson, writing from Sydney, tells me that the dry-weather molluscs of that region hide under twigs, logs, and scraps of wood, æstivating in many cases, so that they are almost certainly transported with the tre-

'J. Shaw, quoting a letter received from Mr. Wright, "Nature," xlii. (1890), p. 637 . 
menclous dust storms, or "darling showers," which sometimes blow over the country, carrying with them twigs, leaves, dust, etc.; at times also, he says, more frequently in dry seasons than in wet ones, dust-columns are formed, which, travelling with a rotary motion, whirl up to a height light articles of all kinds that may happen to be within their reach. Mr. Belt, when in Australia, saw scores of these dust-whirlwinds, many rising to a height of over a hundred feet, and some strong enough to tear off limbs of trees, and carry up the tents of gold-diggers into the air. Many were observed on a small plain near Maryborough, in Victoria, where in calm sultry weather during the heat of the day, two or more were often in action at once on different parts of the plain; the dust and leaves carricd up rendered their spiral movement very conspicuous, as, lasting several minutes, they slowly moved across the plain like great pillars of smoke. From whirlwinds of this sort, Mr. Belt remarks, there is a complete gradation through larger whirlwinds and tornadoes to the awful typhoons and cyclones of China and the West Indies.' As helping us to understand what may be done by causes of the present kind, short accounts of two rather powerful whirlwinds, one of which occurred in our own islands, may be given. Sir C. Lyell writes :

"Dr. Franklin tells us, in one of his letters, that he saw, in Maryland, a whirlwind which began by taking

1 Thomas Belt, "Naturalist in Nicaragua," ed. 2, ( IS88), pp. $301-4$. 
up the clust which lay in the road, in the form of a sugar-loaf with the peinted end downwards, and soon after grew to the height of forty or fifty feet, being twenty or thirty in diameter. It advanced in a direction contrary to the wind; and although the rotatory motion of the column was surprisingly rapid, its onward progress was sufficiently slow to allow a man to keep pace with it on foot. Franklin followed it on horseback, accompanied by his son, for three quarters of a mile, and saw it enter a wood, where it twisted and turned round large trees with surprising force. These were carried up in a spiral line, and were seen flying in the air, together with boughs and innumerable leaves, which, from thcir hcight, appcared reduced to the size of flies." 1

The following account of a whirlwind in Ireland in IS72, was printed in Nature in that year:

"In a letter to the Belfast Nerus-Letter, Mr. C. J. Webb descrites an extraordinary whirlwind which occurred in the district around Randalstown, about six miles northwest of Antrim, near the shores of Lough Neagh, on the 25th of August last [1872]. The same phenomenon was witnessed about an hour and a half earlier the same evening at Banbridge, about seven miles southwest of Dromore. It was first seen near Randalstown about 5 p.m. between that place and Toome, moving rapidly up Lough Neagh from the south, and presenting the appearance of a defined column of spray and clouds, 
whirling round and round, and not many yards in breadth, while at its base the water was lashed into a circle of white foam. It was next heard of in the neighbourhood of Staffordstown, about a mile from the lake, where it partially unroofed two houses, and damaged any trees or crops which happened to be in its course. From this point it travelled in a straight linc for Randalstown, about three miles distant. It passed across a ficld close to Mr. Webb's house, levelling cight haystacks, and carried a considerable part of the hay up into the air out of sight. . . . Everything it lapped up was whirled round and round, and carried upwards in the centre, while dense clouds scemed to be sucked down on the outside, and came close to the carth. . . Mr. Webb next observed its track in a hollow, some three hundred yards further on, where it knocked down a haystack, and then plunged into a wood of fine old Irish oaks. Here it tore numerous branches and limbs from the trees, carrying some along with it, and throwing others to the ground. . . . It next passed across a corner of Shanc's Castle demesne. Some who were at a short distance from this point describe its approach as causing considerable alarm. . . It crossed the valley over the railway viaduct, close to Randalstown, fortunately avoiding the village. It here presented the appearance of a vast whirling column of leaves and branches, mingled with clouds which looked like smoke. The railway station next suffered, innumerable slates and two and a half hundred-weight of lead being torn from the roof in an instant. A great part of the railings 
surrounding the gardens was torn up, and an iron bar, one inch thick, belonging to the gate, was bent to an angle of sixty degrees. A small shed at the rear of the station was unroofed, rafters and slates being hurled to the ground. What will give some idea of the excessive pressure of the wind, is the fact that three boards of the flooring of the waiting-room were forced up, owing to the wind finding an entrance to a cellar underncath, though the only aperture was a round hole about one foot in diameter. All this was the work of a few moments. The storm then passed away, leaving comparative calm behind. It next crossed an adjacent bog, scattering the turf in all directions. The last place Mr. Webb heard of its having visited was a farm house about three miles from Randalstown, between Antrim and Ballymena." I

As remarked by Sir C. Lyell, whirlwinds occur " at different intervals of time throughout a great portion of the earth's surface," and it seems reasonable to suppose that many organisms may have been widely dispersed by them, as well as by the larger circular storms which occur in certain parts of the world; from time to time these causes may carry plants, insects, and, as Lyell says, "land testacea and their eggs, with many other species of animals, to points which they could never otherwise have reached, and from which they may then begin to propagate themselves again as from a new centre." 2 Leaves and other vegetable débris,

1 "Nature," vi. (1 872 ), 2, ( I 888$),$ p. 303 .
I ; and see Belt's "Nicaragua," ed. 2 "Principles," ii. p. 392. 
when carried to great heights, Mr. Wallace observes, may occasionally be drifted off by strong upper currents and dropped at great distances, "and with them small insects and mollusca or their eggs." "

"On 27th July, I875, a remarkable shower of small pieces of hay occurred at Monkstown, near Dublin. They appeared floating slowly down from a great height, as if falling from a dark cloud which hung overhead. The pieces picked up were wet, and varied from single blades of grass to tufts weighing one or two ounces. A similar shower occurred a few days earlier in Denbighshire, and was observed to travel in a direction contrary to that of the wind in the lower atmo. sphere." 2

From what distances the hay had come in these cases no one can tell; it was, however, in a position to be conveyed, as Mr. Wallace remarks, to almost any distance by a violent wind, had such occurred at the time; doubtless it was originally taken up by whirlwinds, and this was the case also, in all probability, with the leaves which fell in Dumfriesshire in I8S9. Slight whirlwinds, according to Lyell, may frequently be obscrved in our fields, in summer, carrying up haycocks into the air, and then letting fall small tufts of hay far and wide over the country ${ }^{3}$ the Irish whirlwind of I 872 as just noted carried a large quantity of hay into

1 "Island Life," p. 274 , ed. 2, p. 285.

"Wallace, "Darwinism," ed. 2, (1889), p. 362 ; quoting "Nature," xii. $(1 \$ 75)$, pp. 279,29 S.

3 "Principles," ii. p. 392. 
the air out of sight, and that observed in Maryland carried leaves to such a height that they appeared reduced to the size of flics. It is clear cnough, I think, from these facts that molluscs-even large and heavy kinds-particularly those living a mong vegetable débris, dead leaves, and the like, may frequently be carried from place to place during whirlwinds, and it has even been suggested also that those inhabiting open plains or pastures may similarly be caught up and conveyed. The idca that snails-Helix virgata, for instance-somctimes descend in showers, may have originated in some cascs, Mr. Jeffrcys thinks, " in a whirhwind having caught up a number of them by sweeping along a grassy plain and dropping its contents in a limitcd area." "

\section{Animal Agencies.}

Animals of various sorts in all probability, as we have scen, have been actively engaged in the dispersal of fresh-water molluscs, and this remark holds good, no doubt, for terrestrial kinds. Something, there is reason to suppose, has been done even by insects. Under

1 "British Conchology," i. (IS62), pp. 2II-I2. For a popular allusion to wind-dispersal, see Dickens in the "Chimes": "Toby himself all aslant, and facing now in this direction, now in that, would be so banged and buffeted, and touzled, and worried, and hustled, and lifted off his feet, as to render it a state of things but one degrec removed from a positive miracle, that he wasn't carried up bodily into the air as a colony of frogs or snails or other portable creatures sometimes are, and rained down again to the great astonishment of the natives, on some strange corner of the world where ticket-porters are unknown." 
some loose stones near Rockhampton, Queensland, Mr. Musson recently found a beetle carrying a landsnail of the genus Vitrina (or Helicarion) upon one of its wing-cases; and it would not require a very great stretch of imagination, as he observes, "to consider that, could the insect have taken flight with this strange companion as passenger, it might have been the means by which distribution would have been aided, and thus a new colony be started where possibly the species had been before unknown." Some years ago, at Lambley Dumbles, near Nottingham, the same observer saw one of our common little snails, Helix rotundata, riding about on the back of a woodlouse, and it is perhaps worth mentioning that on another occasion, at Clifton, 13ristol, he saw a full-grown chrysalis-shell (Pupa umbilicatca), not yet aroused from torpor, securely fastened to a specimen of Helix virgata-the zoned-snail-which was crawling out after a shower; these facts, however, are chiefly interesting for their curiosity. Most kinds of animals, no doubt, have helped in the work in some way or other; mammals, for instance, some of which habitually feed on molluscs, often carrying the creatures for short distances, must sometimes let them drop by accident, or desert them on being suddenly attacked or frightened. A rat, after running some paces from home, was once observed to "climb the stalk of a hollyhock, clear off several snails, bring them down in one paw like an armful, and run with them on three legs into his hole," the inside of which was strewn for some distance

${ }^{1}$ C. T. Musson, "Proc. Lin. Soc., N.S.W.," (.), iv. (1SS(y), $3 \delta S$. 
with broken shells. ${ }^{1}$ Miss Warren has suggested to me that small shells, such as those living at the roots of grass, may sometimes stick to the muddy clay on the fect of cattle, and it seems probable that the range of a species within a given country may occasionally be cxtended in this way. But of all animals, with the exception perhaps of man (who has done a great deal in recent times) the ranges of land-shells have certainly been most affected by birds. The waders, it will be remembered, as Mr. Darwin remarked," are great wanderers being " occasionally found on the most remote and barren islands of the open ocean ;" many sorts of birds, it is hardly necessary to repeat, annually migrate across considerable tracts both of land and sea, and most kinds, as every one knows, are liable occasionally to be blown by violent gales of wind to great distances over the ocean; almost every year, for instance, Mr. Darwin states, one or two land-birds are blown across the whole Atlantic, from North America to the shores of the British Isles, and many, to give another instance, even the smaller land kinds, are constantly blown from Europe to the Azores, a distance of nearly a thousand miles; indeed, according to Mr. Godman, scarcely a storm occurs there in spring or autumn without bringing one or more species foreign to the islands."

1 W. W. Attree, in Merrifield's "Sketch of the Nat. Hist. of Brighton," p. 157, as quoted in the "Zoologist," (3), ii. (1878), 90.

2 "Origin," p. 345.

3 " Origin," pp. 326, 328-9; "Island Life," p. 73, ed. 2, p. 75; "Principles, ii. p. 368 ; F. Du Cane Godman, "Ibis," (n. s.), ii. (I866), p. 105. 
Sir C. Lyell, remarking on the wide range of Succinea putris, a land-shell which inhabits moist places on the borders of pools and strcams, suggested that water-fowl might have distributed its ova cntangled among their feathers, ${ }^{1}$ and it scems quite likcly that ova of certain terrestrial kinds may be occasionally thus carried, cither in the feathers or on the fect of birds; indeed, we have a near approach to proof of such transportal, the Rev. Canon Tristram, as we have scen, having once found ova, believed to be those of a Succinea, upon one of the fect of a mallard shot by him, on the wing, in the desert of Sahara. ${ }^{2}$ It is doubtful, however, whether Succince, from the nature of the localities they often or usually inhabit, ought not, for the present purpose, to be classed with fresh-water, rather than with land-shells. Mr. Darwin suggested that the justhatched young, possibly, might sometimes crawl upon the feet of ground-roosting birds, "and thus get transported;" "3 and it certainly seems in the highest degree probable that such is the case, but, as far as I know, no observations in support of such a supposition have yet been made. In one of his letters to Wallace, Darwin mentions having becn interrupted when beginning to experiment on the point. ${ }^{4}$ As was mentioned in chapter ii., small quantities of earth are occasionally

1 "Principles," ii. p. 377.

2 H. B. Tristram, "Zoolocrist," (3), i. (IS77), pp. 260-1.

s "Origin," p. 353 ; and see "Geographical Distribution," i. pp. $3 \mathrm{I}-2$.

+ "Life and Letters," iii. (1888), p. 231. 
found upon birds' feet, and this, perhaps, may sometimes cause small shells or eggs to adhere, or the creatures may possibly become embedded in it. In one case Mr. Darwin removed sixty-one grains, and in another case twenty-two grains, of dry, argillaccous earth from the foot of a partridge, and in the earth, as already mentioned, was a pebble as large as a vetchseed.' As previously noted, also, a woodcock's leg, once received by Mr. Darwin from a friend, had a little cake of earth weighing nine grains attached; and a pigeon, shot in New South Wales in I887, was found to have a small ball of earth surrounding each of its legs ; suddenly-flushed birds, I believe, are not unfrequently found to have mud or clay adhering to their fect. In the Field, in I88I, Mr. Tegetmeier figured the remains of a young partridge, found dead by a correspondent, destroyed, obviously, owing to its inability to drag about the mass of clay which had become attached to one of its feet. The claws, it seemed, had been first encrusted, layer after layer having been subsequently added until a mass of considerable size was formed. In poultry yards and pigeon houses similar occurrences, it is said-never allowed to become extreme-are frequently observed." Professor Newton once sent to Mr. Darwin "the leg of a red-legged partridge (Caccabis mifa) which had been wounded and could not fly, with a ball of hard earth adhering to it, and weighing six and a half ounces." Mr. Swaysland, as is more important for us to notice, several

1 "Oricrin," p. 328.

W. B. Tegetmeier, "Field," Iviii. (1881), p. 330. 
times found little cakes of earth adhering to the feet of wagtails, wheatears, or whinchats, shot, as he assurediMr. Darwin, on their first arrival on our shores, and beforc they had alighted.' Mr. Wallace, we find, dealing with the origin of the land-shell fauna of the Azores, cxpresses the opinion that some kinds may have reached the islands "with the earth that often sticks to the fect of birds," = and cvery one must admit that transportal in this way is at least possible.

Another possible mode of transport, already hinted at, is suggested by the following passage, from pages 326-7 of the "Origin," referring specially to the dispersal of sceds :--

"The crops of birds do not sccrcte gastric juice, and do not, as I know by trial, injure in the least the germination of sceds; now, after a bird has found and devourcd a large supply of food, it is positively asserted that all the grains do not pass into the gizzard for twelve or even eighteen hours. A bird in this interval might casily be blown to the distance of 500 miles, and hawels are known to look out for tired birds, and the contents of their torn crops might thus readily get scattered."

That the "sudden deaths to which great numbers of frugivorous birds are annually exposed must not be omitted as auxiliary to the transportation of secds to new habitations," had already been remarked by Sir C. Lyell, who suggested that birds with recently picked up secds still in their crops would now and then chance to

$$
\begin{aligned}
& 2 \text { "Origin," p. } 328 . \\
& \text { " Island Life," p. } 247, \text { cd. } 2, \text { p. } 256 .
\end{aligned}
$$


be seized by hawks or eagles, which, "soaring across hill and dale to a place of retreat," might, after devouring their prey, leave the seeds to spring up and flourish in a new soil. Now, as birds of many kinds are known to feed largely upon snails, which, no doubt, often remain alive for some hours in their crops, it seems almost certain that these causes may have operated, very rarely, perhaps, for the dispersal of land molluscs; and even fresh-water kinds, though many are thin-shelled, may also have been thus transplanted, but much less frequently, for the restoration of an animal in this manner to a fresh-water habitat is sure to be extremely rare and exceptional. Mr. Cordeaux tells me that after a day's shooting he has frequently opened the crops of birds and found them to contain both land and fresh-water snails, but, like several other ornithologists who have informed me of similar observations, he is unable to say positively whether any of the creatures were alive. Twenty specimens of a Succinea, peculiarly packed together, and four of Pupa muscomm were once found by $\mathrm{Mr}$. W. H. Dikes in the crop of a bearded titmouse (Parus biamicus); all the shells, it is said, were uninjured, but it is not stated that any were observed to be alive." Many birds, it ought, perhaps, to be mentioned, are careful to kill the animals upon which they feed; thus, for instance, Mr. O. V. Aplin has seen a tame magpie breaking the shells of rufous-snails (Helix mescens) -

" "Principles," ed. 9, (1853), pp. 624-5.

2 W. H. Dikes, Loudon's “ Mag. Nat. Hist.," iii. (1830), p. 239 ; and see D. Cooper, Charlesworth's (n.s.), ii. (1838), p. 479. 
of which it was very fond-before cating them. But this habit is by no means common to all birds; some kinds are actually known to swallow living snails, and Mr. Cordeaux has favoured me with his opinion that in all probability the creatures frequently keep alive for some little time after being swallowed; and on this point, fortunately, an obscrvation of much interest has becn recorded, the accuracy of which, Mr. Roberts, of Lofthouse, assures me, cannot be doubted. In September, I 875, it appears, Mr. John Ward, carpenter and bird-stuffer, of Lofthouse, took thirtecn wrinkled-snails (Hclix caperata), together with a quantity of tares, from the stomach of a wood pigeon which had been shot three days previously. Most of the snails were alive, and "began creeping about on being placed in a dish containing a little water." It may be mentioned, as a somewhat analogous case, that Mr. Abel Chapman has frequently shot curlews stuffed with live cockles, which, as he remarks, might casily have been scattered if the birds had chanced to have been killed and carried off by peregrines or other birds of prey. Molluscs thus remaining alive in birds' crops,

1 Mr. Roberts informed me of this fact, without comment, in I 890 , but recently, after drafting this chapter, I was much pleased to find that when recording it, in 1882 , he had suggested that molluscs might possibly be "carried in the crops of birds considerable distances, and thus be distributed and established in new districts, or on islands, as the living shells might be ejected from the crop, or the birds might be killed by birds of prey and the contents of the stomach dislodged and scattered."- "Topography and Nat. Hist. of Lofthouse," I882, p. 333. 
as Mr. Darwin's remarks suggest, may possibly be transported, especially during gales, under exceptionally favourable circumstances, to new homes perhaps several hundreds of miles from their original habitats. At ordinary times birds often fly a long way to feed-wood pigcons, for instance, do so when necessary-and if struck down by birds of prey when returning home, the living contents of their crops might possibly be liberated at considerable distances from the feeding-ground. There is no actual proof, as far as I know, that shells have ever been scattered from crops in the manner here indicated, but an observation of much interest in this connection has been made by Mr. Aplin, who tells me that he once noticed a little heap of barley, evidently carricd from a distance, lying among the remains of two wood pigcons which had been killed by a hawk, probably a peregrine. Even when a snail-eating bird happens to be killed on its feeding-ground, the bird of prey, "soaring across hill and dale" to a hiding-place, and carrying its viction with it, might ultimately scatter a few snails miles from their original home; it may be remarked, however, as Mr. Aplin points out, that except in the brecding season when they have young, hawks, etc., often or usually cat their kills on the spot, or close to it; but it is undoubtedly probable, as Mr. Cordcaux assures me, that both seeds and shells have becn distributed, to some extent, by hawks, owls, etc. sometimes devouring their victims at a distance from where they were struck down. It seems possible, also, that snails in the crops of dead birds may be floated, at rare 
intervals, on the surface of the ocean, to be ultimately liberated, perhaps, on some distant shore. Large numbers of land-birds, I suppose, annually perish in the sea; their floating carcases, Darwin states, sometimes escape being immediately devoured, ${ }^{1}$ and, as shown by $\mathrm{Mr}$. Ward's observation, a Helix can retain life in the crop of a dead bird at least for three days. In such circumstances, of course, molluscs would be protected to some extent from the evil influences of salt water, and, in illustration of this point, it may be noted that a number of seeds of peas and vetches (which are killed by a few days' immersion in sea-water) nearly all germinated after having been enclosed in the crop of a pigeon which had floated on artificial sea-water for thirty days."

Various kinds of birds, it will be remembered, have been observed to eject the contents of their crops when frightened or wounded, as gulls and terns do when pursued by the skuas, and it seems quite possible, as Mr. Roberts has already suggested, that snails, still alive, may occasionally be thus disgorged, and set down in places perhaps some considerable distance from the spot where they were picked up and swallowed. Mr. Clement Reid suggests that a good deal may have been done, also, by birds gorging themselves after a long and wearying migration, and afterwards casting up the contents of their stomachs, little injured, and perhaps a considerable distance away, and he states that he has 
several times come across castings of this kind, containing soft seeds, live worms, etc.

It must be borne in mind, of course, that the transportal of shells by these agencies to distant points over the ocean can only very rarely happen, but, as Mr. Wallace has remarked, "nature can afford to wait," and if but once in a thousand years, he adds, "a single bird should convey two or three minute snails to a distant island, this is all that is required for us to find that island well stocked with a great and varied population of land-shclls." "We must remember, however, that resulting colonization is much more rare than mere transportal, though, of coursc, snails carried by birds into the interior of new countrics or islands, or to some little distance inland, are more likely to be able to establish themselves than are those stranded upon the shores with drift-timber, etc. The creatures are carried, we may feel sure, for comparatively short distances within given tracts of land much more frequently, and many apparent anomalies in local distribution no doubt have thus arisen, but even here the ultimate establishment of a new colony seems likely to be a rare event. Additional ways in which short migrations may possibly be brought about might be referred to. Small shells, such as those of the genus Vertigo, and eggs of various kinds must occasionally happen to be adhering to twigs, etc., carricd off by birds when building, and these are sometimes collected at some little distance from the nest; cvery one, no doubt, remembers having seen rooks

$$
1 \text { "Geographical Distribution," i. p. } 32 .
$$


flying overhead with twigs in their mouths. A living specimen of Limnea truncatula - the "ditch mud-shell" of Gray's Turton-once found, as the reader will remember, on the top of a church in Preston, had very probably been carried therc, as Mr. Heathcote suggests, adhering to one of the sticks taken up by a jackdaw building in the tower. Thrushes, red-wings, etc.-great snail-eaters-as Mr. Cordeaux remarks to me, will carry shells to considerable distances, and from being disturbed or otherwise may sometimes drop them, or neglect to break them against their favourite stones, and $\mathrm{Mr}$. Roberts, I hear, has actually seen a thrush drop a snail while flying. Quite recently, I found-on a snowcovered road in Lincolnshire-a hibernating snail, Helix aspersa, which, having a pierced epiphragm, had almost certainly been carried and dropped by a bird. Nostones on which shells had been broken were near, but several were seen at some distance along the same road. On being placed in tepid water the snail revived, and crawled away.

Operculate land-shells, it seems probable, may occasionally be carried in the manner already suggested for operculate pond-snails in chapter iv., namcly by closure of the operculum, so as to hold on to the tocs of insects, etc. As there mentioned, a land-shell has been seen holding on to a humble-bec in this way. The observation referred to was made in June, IS85, and recorded in the Field in that year.' The

'F.W.T., "Humble-bee trapped by snail," "Field," lxv. (1885), p. $S+3$. 
observer, it appears, while walking along by the roadside, saw a large orange-tailed humble-bec, "vigorously towing something heavy after him," which, on inspection, proved to be "a Clausilia [Cyclostoma?] the little snail which has an operculum-like plate on the lip;" the latter had fast hold of one of the hind legs of the bee, by which, no doubt, it had been accidentally trodden upon. The smaller operculate-shells, it can hardly be doubted, may possibly be carried in this manner to considerable distances by the large and powerful insects which abound in some parts of the world. 


\section{CHAPTER VII.}

DISPERSAL OF SLUGS.

SLUGS, obviously, are not so well fitted for dispersal as snails, for many are quite naked, and thougin some possess small external shells, the well-developed snailshell, into which the animal can retire for rest and during periods of adversity, and which, often closable by an epiphragm or operculum, has doubtless largely facilitated the dispersal of shell-bearing kinds, is always absent, and it is clear, therefore, that many of the considerations referred to in the preceding chapter cannot be looked upon as necessarily applicable to the slugs, such creatures being sure to succumb to many of the hardships from which snails may often have escaped in safety. Many slugs, it is notorious, from containing much water, cannot even bear exposure in a dry atmosphere for any length of time, but in many respects, it should be remembered, animals of this kind are much more tenacious of life than might at first be supposed, and this is true of our ordinary absolutely naked sorts, Limax, Arion, ctc. The Testacelle, which have a small ear-shaped shell near the extremity of their bodies, "snail-slugs" of some authors, are able to protect them- 
selves by forming a kind of cocoon "secreted from their skin and often mixed with earthy and extrancous particles": the "nest of earth" made by $T$. mangei in times of drought, it is said, reminds the observer of the cocoon of the puss-moth; within, the animal lies encysted until moisture, finding its way through the walls, rouses it again to activity. While in the encysted state "a thin white membrane (a development of the mantle) is extended from bencath the shell and stretched over the back and sides of the animal," checking evaporation, and forming an admirably-designed protective shield. ${ }^{1}$ The Testacella's power of retaining life under adverse conditions is well illustrated by observations made by Professor Poulton in I 886 :-

"Between four and five months ago I found eleven specimens of this slug [Testacella, species not stated] upon a low wall surrounding the garden of a house near the Oxford University Parks, and on the following day I captured eleven more in the same place. . . . A few of the twenty-two specimens were killed and hardened, and the remainder were put in a box containing earth, in which they buried themselves. In the press of other work the box was neglected, and remained untouched in my laboratory until to-day [October I9th], the earth having quickly dried into a hard cakc. To-day I emptied the box, and fully expected to find the slugs dried up dead, but to my surprise I found twelve specimens alive, each encysted 
in a thin transparent capsule formed of the hardened mucous secretion of the animal's skin. The body was contracted, and oval in shape, but it had becn so completely protected from evaporation that therc was no noticeable reduction in bulk after these hottest months of the year, during which water had been entirely withheld. One or two specimens had died almost immediately after capture, and a few escaped, so that all those which had been exposed to the heat and dryness in the box had become encysted, and survived in apparent health." 1

Slugs in such a condition at the roots of trees, etc., would be nearly as well fitted for dispersal as snails, at least by fresh-water currents.

Slugs of most sorts and the eggs of some kinds must certainly be carried to short distances within given landareas with some frequency; various means, organic and inorganic-probably of kinds already suggested-operate no doubt to bring about short involuntary migrations. River agencies must have widely scattered the creatures. Some are arboreal, inhabiting old and decaying trees which, when blown to ground, or washed out of riverbanks, must sometimes be carried off by floods. In our own country we find slugs-the great grey kind, Limax maximus, for instance-living under the bark of old willows by river-sides. At times, too, we find them well concealed in chinks and among débris in the interior of hollow trees, and, like some snails, they probably eat 
their way into the decaying wood, for several specimens of L. merimus, found when removing rubbish and breaking away parts of the wood from a cavity in the trunk of an old hornbeam, subsequently extruded pale yellow pellets composed entirely of "saw-dust." In these situations the creatures would often be well protected, so that they might be carried in safety with floating trunks to great distances. Many kinds, it must not be forgotten, live mostly on the ground, rarely or never ascending trees, and these of course are not likely to be carried with timber, unless they occasionally hide themselves in logs lying upon the ground; they must frequently be swept in numbers from their haunts on grassy or muddy river-margins, but unless buoyed up by some object, they are not likely to be much dispersed by the currents, for I believe they always sink in water, and when carried away by the rushing waters of torrents or floods are hardly likely to be often landed again in a living state. It seems probable, however, that they may sometimes be safely floated upon vegetable-rafts of many sorts. A few years ago, indeed, I had the good fortune to witness the conveyance of a slug by this means, upon a very fragile raft. Walking in the evening from the Lincoinshire coast towards Louth along the banks of the Eau, I saw a large black slug (Arion ater) crawling with out-stretched tentacles upon a mass of "green-scum" which came drifting down with the current at a good way from the bank. This was at no great distance from the sea, and in all probability the animal was ultimately carried out and drowned, but pos- 
sibly it might be landed on one of the banks or arrested by some projecting object, so as to be able to crawl away in safety. Previously I had noticed that the level of the water had risen rapidly, and the scum, lying, no doubt, earlier in the evening stranded upon the mud at the water's edge, had evidently be enfloated off with its living burden by the "flood." Slugs of the same kind were numerous a long the muddy margins for a considerable distance. The smaller ground-slugs, no doubt, like little shells of many kinds, often resort to the hollow "kexes" of umbellifers, which, as already mentioned, seem likely to serve as vehicles for transportal : the marsh-slug (L. levis) has been noticed in the stems of these plants by Mr. B. Hudson, ${ }^{1}$ and I have seen the field-slug (L. agrestis) in such stems lying upon the ground near a little water-course in Highgate Woods. Kinds which habitually burrow into the ground and spend a great part of their lives beneath the surface seem likely, of course, to be occasionally transported, at least in some regions, in the soil attached to the roots of floating trees, but they are sure to escape, in a great measure, the various accidental causes which above ground bring about comparatively frequent involuntary migrations; thus we find Dr. Simroth regarding the Testacelle as having but little scope for dispersal owing to their subterranean habits, and as a consequence, he says, they have divided up into local forms.?

1 "Journ. of Conch.," v. (1886), p. 48.

" HI. Simroth, "Journ. of Conch.," vi. (1891), p. +23 . 
It cannot be supposed that slugs often cross the sca, and trans-oceanic migration for long distancis, if ever occurring, is likely to be extremely rare. Dr. Scharff has stated, indeed, that the sea, "which is the principal means of communication for other animals, and plants, between mainland and island, forms an almost impassable barricr for slugs, sea water being deadly both to their eggs and themselves;" I do not think it necessarily safe, however, to assume, as that author does, that "if we find the slugs of mainland and island agrecing in anatomical characters, we may generally conclude that the island must have had a land connection with the mainland at some time or other," for this secms to imply that the creatures are incapable of crossing the ocean, and it is a fact, as I hear from Dr. Scharff, that their chances of surviving a sea passage are regarded by him as practically nil. But what do we actually know of the ways in which the various organisms are or have been distributed over the globe? Unthought-of means, even for the dispersal of sluss, may be in operation, or may have operated in former times. I have not ascertained whether any of the true oceanic islands, independently of man's dispersal, possessed slugs belonging to continental species or genera, but such I presume was the case; some kinds certainly scem to enjoy fairly wide ranges, but in many cases I suppose it would be difficult to ascertain to what cxtent man has affected their distribution. Few land

1 R. F. Scharff, "Sci. Trans. Royal Dublin Soc.," (2), iv. (1891), p. 513 . 
molluscs, it is said, have attained so wide a range as our own little marsh-slug (Limax levis), which, "under different names by various authors," has been recorded from Europe, North and South America, the West Indies, Madagascar, Australia, New Zealand, and many islands of the Pacific.' Possibly or probably it has been carried to some of these regions by man, but it is interesting to find that in Australia, for instance, where it occurs "in very out-of-the-way places, and far away from the coastal cities," it is regarded as truly indigenous." Very probably, as it appears to me, these creatures are able in some way or other to journey over the sea-no doubt rarely-for short distances at least, and it scems possible also that accidents leading to transit over the ocean for very considerable distances may have occurred now and then in the course of the vast periods during which these naked genera have inhabited the carth, but we are unable, it is true, to refer to any actually observed occurrence that can reasonably be said to lend direct support to this view. The creatures' eggs, it will be remembered, do not differ essentially from the eggs of many snails. Those of certain kinds are deposited in the trunks of hollow trees; thus, for instance, Dr. Scharff mentions having found ova of the yellow-slug (Limax flavus) "in an old tree trunk, near Dublin," 3 and those of the tree-slug (L. arbormm), I

"C. Hedley, "Proc. Lin. Soc., N.S.W.," December, I890, as quoted in the "Nautilus," v. (1891), I2.

${ }^{2}$ C. T. Musson, "Proc. Lin. Soc., N.S. W.". for $1890,(2)$, v. (I891), p. 885 .

3 "Sci. Trans. Royal Dublin Soc " (2), iv. (ISOI), p. 522. 
suppose, are usually placed either in the hollows or under the bark of trees. In such situations, protected, or partially protected, for a time from contact with sea water, ova might possibly be carried with floating trees over small arms of the sea, and perhaps even to islands, though rarely if ever to very remote ones. The animals themselves thus hiding might also be carried, I think, in a similar way. It is just possible, also, that eggs may be occasionally carried over the sea, at lcast for short distances, in the cavities of pumice, or in earth at the roots of trees. Large numbers, both adults and ova, must certainly be carried out to sea by large tropical rivers with floating rafts or islands, which have already been refered to, and if such objects have ever been stranded upon more or less distant shores so as to permit their inhabitants to be "poured out as from an ark," which was regarded as possible by Lyell,' any number of slugs may have been thus transported. Hurricanes and whirlwinds may have carried the creatures and their eggs (sometimes laid amongst dead leaves) over straits and small arms of the sea, and the just-hatched young are as likely as those of snails to crawl upon the feet of ground-roosting birds, and thus possibly they may be carried over sea, provided, of course, that they adhered firmly; this may be the case at a very early age, but later, I find, and more especially when young than adult, the creatures often let themselves drop purposely, 
either with or without a slime-thread, from small objects upon which they may be placed, and young slugs, it should not be overlooked, soon perish from cxposure, so that after a little time," even if they adhered, they would be sure to dry up and die. Dr. Scharff raises a further difficulty; supposing that a couple of young slugs, he writes, happened to stick to the feet of a bird and were carried a long distance without being shaken or blown off - which in itself he regards as unlikely cnough-on being safely deposited on the ground they would "still have to keep together" until mature, and not lose sight of one another in order to propagate their species." The difficulties constantly attending the establishment of new colonies as the result of all occasional means of dispersal, it must of course be admitted, are very great, and this fact, as already insisted, must never be lost sight of, but in connection with the present point it may be uscful to remember that many kinds of birds migrate in immense numbers year after year along the same lines. To give an imaginary case: hundreds of migratory birds, let us suppose, roost together among tufts of herbayse in a swamp, where slugs, hatching out from the egg, and abounding on al! siles, adhere in numbers to their fect; procecding on migration, after a few hours, over an arm of the sea, they might deposit on the opposite shore a number of indivicluals, which, joining others similarly transported in former years, might become frrmly established in the new home; or losing their way in a fog or otherwise, the birds might chance to alight altogether on some 
lone islct, at no great distance, all the moist surfaces of which, previously uninhabited by slugs perhaps, might possibly be found, after a few centuries, as some traveller might record, swarming with a kind common to the mainland. We are bound to conclude, however, I think, that in all probability dispersal over sea, with subsequent colonization, even to short distances, is very rare, and such dispersal over wide stretches, though perhaps not impossible, can hardly be supposed to have happened, by any known means, more than once or twice in the course of vast ages. One other point deserves attention. Slugs are known to be largely caten by many birds; we find, for instance, that young chickens and ducks are sometimes employed with good results for the purpose of keeping the creatures within bounds in kitchen gardens; when the former are allowed the frec range of a garden they may be secn, it is said, at daybreak, regularly scarching rows of cabbages and broccoli, picking up slugs, ctc.; plovers and gulls also, thus employed, are stated to be very uscful, and a tame petrel is said to have proved valuable for the same purpose. ${ }^{1}$ If the creatures can survive in the crop for a few hours, it would certainly secm that they may be transported, as already suggested for snails, for short distances, and if they can survive say for twelve or cightecn hours, they may be carried over sea, in exceptional circumstances, according to an

1 "Garden," x. (1 876 ), p. 435 ; xiii. (1878), pp. 275, 304, 350; xvi. (1879), p. 391 ; "Gardeners' Chronicle," I878, p. 664; "Science Gossip," I868, p. 46; etc. 
estimate of Mr. Marwin's, even for a distance of 500 miles, and remaining alive in the crops of dead birds, they might be drifted on the surface of the occan possibly to a still greater distance. The late $\mathrm{Mr}$. J. W. G. Spicer, of Spyc Park, Wilts, once recorded the shooting of pheasants in the Holt Forest with their crops completely full of a small white slug, but he gave no indication as to whether any were alive, ${ }^{1}$ and perhaps it is hardly likely that these shell-less creatures can retain life for any considerable time in the warm crop of a bird, and it is to be remarked, also, that they are certainly more likely than snails to be killed or severely injured when picked up and swallowed.

' J. IV. G. Spicer, "Zoologist," (3), v. (1881), p. 383. 


\section{CHAPTER VIII.}

DISPERSAL OF FRESII-IVATER AND LAND MOLLUSCA BY MAN.

In comparatively recent times many molluses have becn widely scattered over the giobe by man. Indeed it may be safely said that both smails and slugs, during the last three centurics at least, have been more dispersed by human agency than by all other causes together. European species, for instance, thus disscminated, as everyone knows, have become thoroughly naturalized in many parts of the world, even in the most remote colonies. Many facts illustrating the cxtent to which certain faunas have been alloyed by man might be given. All the species of Limar described as native to Australasia are referable, according to Mr. Hedlcy, cither to L. mrrimus, furous, gergates, agrestis, or lavis, all, cxcept the last, believed to have been introduced by man from Europe." The Madeiran Islands, to give another instance, discovered

1 See Woodward's "Manual," ed. 4, rep. 1890, p. 289.

" C. Hedley, "Ann. and Mag. Nat. Hist.," (6), ix. (1892), p. 170 ; C. T. Musson, "I'roc. Lin. Soc., N.S.WV." for I890 (2), v. (189r), p. 885. 
in I4IS, sca-girt, and less than 400 square miles in area, possess, according to the Rev. Dr. Watson, no less than thirteen kinds of molluses (six slugs and seven land and fresh-water shells), belicved to have been introduced by man, and now well-naturalized, namely :Arion atcr, Limar gagates, L. maximus, $L$. flawus, $L$. agrestis, Testacellar mangei, Hyalinia collaria, Helix pulchella, Bulimus decollatus, B. ventricosus, Cochlicopa lubrica, Limner acuta, and "Ancylus striatus Q. and G." ; and there are also six other similarly introduced kinds-Testacella haliotider, Helix aspersa, H. rotundata, Planorbis glaber, Physa acuta, and Hydrobia similismuch more recently imported, and hardly to be regarded as truly naturalized. ${ }^{1}$ Snails thus introduced, as it is interesting to note, often increase with surprising rapidity; it is notoriously dangerous, indeed, to turn out any creature in a new country, where its cnemics are possibly absent, and the truth of this has becn sorrowfully cuforced in some of our own colonics. The European IIyerlinia cellerion, it is said, occurs literally in hundreds in the space of a few square fect near a water-fall in St. Helena; the British Cemetery at Bucnos Ayres, according to a recent report, is "overloaded with Melix pomatic; " our common garden snail (Helix (rsperser), introduced into the Cape apparently within the memory of a living naturalist, is there astonishingly prolific; Mr. J. S. Gibbons, in I 878 , mentioned that he had nowhere seen it in such plenty as near Cape

R. B. Watson, "Journ of Conch.," vii. ( I 892$)$, pp. I·3.

$$
\text { N } 2
$$


Town ; ' in Australia, too, as Mr. Hedley tells me, when it once obtains a footing it increases at an enormous rate, until there are far more shells to the square yard than are commonly seen in Europe; in the Botanical Gardens of Sydney, for instance, it absolutely swarms. Some hundred living specimens of Helix nemoralis, imported from England by Mr. W. G. Binney in I 857 , increased with great rapidity in his garden in Burlington, New Jersey, and by I878 the whole town was said to be full of them ! ${ }^{2}$ At Lexington, Virginia, also, this snail, first noticed in I886, probably introduced accidentally, appears to have multiplied at a wonderful rate; about I889, Professor J. H. Morrison, who had transplanted the creatures to several fresh places, is said to have collected over four hundred specimens in about an hour's time within a radius of twenty-five yards. ${ }^{3}$ Slugs in similar circumstances sometimes increase with equal rapidity: in Victoria, in I849, Mr. John Carson states, a slug found in his garden was welcomed as an old friend and carefully restored to its feeding-ground, but by the following season "matters had changed" and it was every night's work to pick up "pints full"; the warm, moist autumn and mild winter of the region proved specially congenial, and the creatures became a plague, unequalled, it is said, by

' J. S. Gibbons, M.B., "Quart. Journ, Conch.," i. p. 367 ; W. H. Rush, "Nautilus," vi. (I892), p. 8I.

" IV. G. Binney, "Terrestrial air-breathing Mollusks," v. (1878), p. 379 .

3 H. A. P'ilsbry, "Nautilus," iii. (18S9), pp. 5 1-2. 
anything ever experienced in England.' Similarly among fresh-water groups the notoriously rapid multiplication and spread of the introduced zebramussel (Dreissena polymorplac) in England and certain parts of the continent of Europe may be instanced; a statement by Sir C. Lyell that a Limnee introduced unintentionally into Madeira by the Portuguese ran all over the island in thirty years has already been referred to. It will be borne in mind of course that molluscs, no matter how quickly they increase, can never spread with much rapidity of their own accord; obviously, migration at a "snail's pace" can hardly be rapid, and those kinds which have quickly occupied large areas must certainly have been largely helped by external causes.

Man's influence upon a fauna, it need hardly be remarked, is not always by way of addition, for he often drives away or exterminates many aboriginal forms. The introduction of new and dominant kinds must in itself be highly prejudicial, while the disastrous results attending the destruction of forests and the breaking up of land for cultivation are but too well known. St. Helena furnishes a striking illustration. When discovered in I5OI, the little island is said to have been clothed with a luxuriant forest vegetation, but the woods have been almost wholly destroyed by man and the animals introduced by him; and notwithstanding the establishment of a large number of foreign plants, its general aspect is now described as barren and "John Carson, "Ciarden," xiii. (IS78), p. 273. 
forbidding. Much of the rich upper soil, which could only be retained on the steep slopes so long as it was protected by vegetation, has been washed away by the violent rains. ${ }^{\prime} \quad$ As a result, we find that of the twentyseven truly indigenous species of terrestrial mollusca belonging to the island-and the fact has already been mentioned-only seven now survive, the remainder having been exterminated, Mr. Edgar Smith remarks, "by the destruction of the primeval forests." Foreign snails have been introduced, and are now living on the island, imported probably, perhaps as ova, with "some of the many introduced plants;"2 the presence of Hyalinic cellaria, for instance, has just been referred to: these, however, from a naturalist's point of view at least, form no real compensation for the loss of aboriginal forms, the destruction of an inoffensive member of a native fauna-more especially when highly peculiar-being an irreparable calamity.

Shells have been intentionally dispersed by man to a considerable extent. Both land and fresh-water kinds, as everyone is aware, have frequently been "planted," chiefly by shell-collectors, in localities where they were previously unknown, and permanent additions to faunas, it will be admitted, have thus been made. To some persons the transplantation of foreign or local snails to spots near their residences seems to have special fascination, and a whole volume might probably be filled

1 Wallace, "Island Life," I 880, pp. 28 I-4 ; ed. 2, I 892, pp. 292-5; and see aiso Darwin's “ Journal," ed. 2, 1845, pp. 488-9.

"See Darwin's "Journal," pp. 489-90. 
with accounts of such doings, but we are not much concerned with this kind of dispersal. Numerous unsuccessful attempts at colonization have been recorded, and these are of significance, I think, as helping us to understand how very small must be the chance of the ultimatc cstablishment of a new colony as the result of transportal-often, no doubt, to very unsuitable spots-of a solitary specimen or a few individuals by accidental means under nature. Man often carrics considerable numbers, turning them out in localitics apparently wellsuited to the requirements of the particular species he wishes to acclimatize, sometimes even watching over them with care and shooting the birds which come to pick them up, yet it often happens that the creatures gradually decrease in numbers and finally die out. It must be remembered, however, that when thus carried by man they are generally put down in districts already wcll-stocked, and the creatures in sucl cases are obviously less likely to survive than those which happen to be transported by natural means to poorly stocked regions or to newly formed and uncccupied islands. The few accounts of attempts at colonization which I have noted down may possibly be worth giving. Unsuccessful attempts, it should not be forgotten, are probably less likely to be placed on record than successful ones.

The zcbra mussel (Dreissena polymorpha) is said to have been planted by Mr. Stuchbury of Bristol in some of the waters near that place,' and similarly, in America,

'H. E. Strickland, "Marr. Nat. Hist.," (n. s.), ii., ( $\left.\varepsilon_{3} S\right)$, p. $3{ }^{6} 3$. 
Dr. James Lewis is stated to have put down several species taken from the Mohawk River-Melantho integra, M. rufa, Goniobasis niagarensis, Somatogynus isogomus, ctc. -at the outlet of Schuyler's Lake (about eighteen miles from Mohawk), but I do not know the result of either of these experiments; an attempt made by Dr. Lewis to colonize "Vizipara contectoides Binney (Pal. rizipare Say)" in the Mohawk River and Eric Canal, however, is said to have been eminently successful, the species having spread widely and being now "firmly established in both the canal and river," "and I find it stated also that Bythinio tentoculato, planted in the Mohawk River by the same naturalist, has become very abundant, especially in the bends of the river where the water runs slowly. ${ }^{2}$ Planorbis corneus and B. tentaculate, planted by Miss Esmark in Norway, "increased rapidly;" Limnad strgnalis intentionally introduced, it is said, as food for trout, into the river Avon at Christchurch, New Zcaland, was said to be abundant below the Acclimatization Gardens in I88 I ; the same species, from Ingland, thrown down in an old quarry and in deep drains at Possil Marsh near Glasgow, is known to have survived at least for some years, ${ }^{4}$ and Spharium lacustre, Pahdina contecta, B. tentacu-

' W. B. Marshall, "Nautilus," v. (I 892), pp. I33-4, quoting Dr. Lewis, "American Journ. of Conch.," iv. (I868), p. 245.

"A. F. Gray, "American Nat.," xvii. (1883), p. 205.

3 F. W. Hutton, "Trans. and Proc. New Zealand Inst.," xiv. (1881 ), p. I 57 ; C. 'T. Musson, "Proc. Lin. Soc., N. S. IV." for 1890, (2), r. (I 891 ), p. 889 .

+ W. D. Roebuck, "Scot. Nat.," I891, p. 130. 
lata, Planorbis carinatus, $P$. complanatus, $P$. cornous, $L$. stagnalis, and L. glabra, from localities, likely to be destroyed, in the neighbourhood of Manchester, deposited by Mr. Heathcote in quiet ponds about Farrington, were stated in I 887 to be increasing rapidly in their new homes.' A good deal of colonization from pond to pond and from a distance, Mr. R. D. Darbishire states, used to be practised in the neighbourhood of Manchester; Pl.corneus, for instance, believed to have been absent from the district in I84I, "is now common in the canal at Gorton-most likely a dealer's colony ;" in I $844-6$, it is said, "there was a great rush to Southport" for Paludina contecta which was colonized by collectors and dealers in canals near Manchester, at Twenty Pits, Greenheys, and cotton pits, Chorlton; $P$. vivipare, also, at Birch, is regarded as a probable introduction. ${ }^{2}$ On the other hand, L. stagnalis, put down by $\mathrm{Mr}$. W. Baillie in a stream near Brora, Sutherlandshire, probably "picked by birds," could never afterwards be found ${ }^{3}$ S. corneum, B. tentaculato, and L. stagnalis, introduced into a dam near Greenock, seemed to have died out by the following year; ${ }^{4}$ and of several living specimens of L. stagnalis and Pl.corneus, placed in a small pond on

'R. Standen, "Nat.," I887, p. I76.

" R. D. Darbishire, cited by Mr. Standen, "Nat.," I887, pp. I60 and 164 .

${ }^{3}$ Neritina fluriutilis, B. tentaculata, and Pl. compllanatus have also been planted in small numbers by Mr. Baillie in the neighbourhood of Brora.

4 T. Scott, "Trans. Nat. Hist. Soc. Glascow," (n. s.), i. (I887), 1. $2 \$ 2$. 
Redcar sandhills in I8S2, only a single half-grown specimen of the former could be found in $1884-5 .{ }^{1}$

With land-shells much more seems to have been done. The Roman or edible snail (Helix pomatia) has often been cxperimented upon. It is even said by some to have becn originally introduced into this country from the continent, but this is a point to be considered in the next chapter. Specimens from Stoncsficld, Oxfordshire, were introduced many years ago into the Botanic Gardens at Oxford, where, it was stated in I883, a large colony "is now thriving." Many ycars ago also a few specimens are said to have been turned out by Mr. Bean in Forge Valley, Scarborough, and individuals, as reported in I868, were subsequently found there from time to time; Mr. Ashford mentions having secn a full-grown living shell, taken in the locality in April, I 868, "doubtless a descendant of the originally transferred stock."' Mr. T. D. A. Cockerell records the liberation of four specimens near Chislehurst, two of which were secn again after nearly two years. ${ }^{4} \mathrm{Mr}$. Thompson, in I84I, stated that the creature had "of late years been introduced from England to different localitics in Ireland, as Dalkey Island, off the Dublin coast, Youghal, ctc. ;" in the autumn of 1834 a few had been turned out by him, together with Cyclostoma elegans, on the chalk near Belfast, but they did not increase, and

1 B. Hudson, "Journ. of Conch.," v. (I886), p. 48.

"S. S. Pearce, "Zoologist," (3), vii. (I 883), p. 365.

3 C. Ashford, "Science Gossip," I868, p. I60.

+ T. I). A. Cockerell, "Journ. of Conch.," iv. (I884), p. 239. 
after a few months not one of either species could be found about the place.' Specimens were introduced into Scotland "by Pat. Ncill, Esq., and placed in his curious and most interesting garden at Cannonmills," but they did not prosper, and, as Dr. Johnston stated in I 830 , were believed to be gradually disappearing. ${ }^{2}$ Dr. Lukis tried to introduce the creature into Guernsey but apparently without success. ${ }^{3}$ When put down in the neighbourhood of Christiania, Miss Esmark tells me, it always vanishes after the first year: some transplanted from Sweden, for instance, all disappeared, as did others brought from Denmark by Professor R. Collett; probably they were eaten by foxes or hedgehogs which live everywhere in the neighbourhood. ${ }^{4}$ Professor Collett several times tried to transplant the creature in Denmark, only from one estate to another close by, but it always died. According to the Rev. J. Morton, who wrote in I7I2, many specimens were introduced by Lord Hatton into a coppice near his house at Kirby, in Northamptonshire, "with Intentions that they should breed there; but in a short time they all dy'd." " Fifty or sixty specimens were once turned out in the neighbourhood of Petersfield, but did not establish themsclves; here, also, as suspected by Mr. Harting,

' WV. Thompson, "Ann. and Mag. Nat. Hist.," vi. (I841), p. 2 I.

' G. J[ohnston]., Loudon's "Mag. Nat. Hist.," iii. (I830), p. 47.

3 A. H. Cooke and H.M. Gwatkin, "Quart. Journ. Conch.," i. p. 333.

' B. Esmark, "Journ. of Conch.," v. (I886), p. I Io.

J. Morton, "Nat. Hist. of Northamptonshire," (1712), as yuoted in "Journ. Northants. Nat. Hist. Soc." iii. (I $\$ 85)$, p. 319. 
they were probably devolired by hedgehogs. About I 868-9 Mr. W. Jeffery is said to have turned out thirty or forty Surrey specimens partly in his garden at Ratham, Chichester, and partly on a bank of light soil near, but of those on the bank nothing more was seen, and in the garden-though they seemed to do pretty wcll for a time, producing, at least, one brood of young, some of which attained full size-the original stock had all vanished previously to I 874 , and during the preceding summer only two young ones had becn scen.'

Mr. Jeffreys, as he stated in I 862, twice endeavoured, at different times of the ycar, with an interval of nearly three years between each attempt, to colonize the beautiful and local Helix pisana on the sandhills near Swansca; a basketful of living specimens from the well-known habitat at Tenby, only about thirty miles distant, were spread over different parts of the Burrows, where the soil and herbage appeared to be the same as at Tenby, a more easterly aspect at Swansea being the only noticeable difference in the localities, but, as Jeffreys added, although they scemed "at first to thrive tolerably well in the new locality, they did not multiply, and the birds soon ate "up the immigrants." " He was mistaken, however, in supposing that his endeavours had been altogether unsuccessful, for on searching the sandhills in I874, Mr. Rimmer, to his astonishment, found the shell living there in countless numbers and of

"J. E. Halling, "Zoologist," (3), ii. (1878), pp. 89-9o; and see "Rambles in Search of Shells," I875, p. 72.

" "British Conchology," i. (1862), p. 208. 
all ages, a white variety apparently predominating. Mrs. Dyer of Swansea, who is familiar with the species, as Mr. Gude tells me, saw the creatures still living on the sandhills on last visiting their habitat in $I 884$. The original immigrants, it seems, as Mr. Rimmer remarks, did not long survive, "the sudden change, perhaps, injuriously affecting their delicate constitution;" evidently, however, they left behind them a progeny, which, being born in the new home, took more kindly to the place. ${ }^{1}$ Similarly, as stated by Bourguignat, a large number of Helix lactea from Valencia died during the second winter at Castel-Roussillon, but some more vigorous individuals born in the new locality appear to have survived for some time; finally, in this case, howcver, all perished." In I860, a son of Dr. Lukis, while staying in Jersey, where $H$. pisanc is abundant, sometimes covering the thistles, ${ }^{3}$ collected a number and carried them to Guernsey, establishing two colonies there, one at Vazon Bay and the other at Vale Castle, and sending a few to his sister, Mrs. Collings of Sark, who turned them out in that island "on the right bank going down to the Port du Moulin." In 1877 , Mrs. Collings reported, however, that none had been seen in Sark for some years; for a few years a shell or portions of a shell had occasionally been found near a stone

'R. Rimmer, "Quart. Journ. Conch.," i. p. 267; and see his "Land and Fresh-water Shells," IS80, 1). 133.

${ }^{2}$ M. J. R. Bourguignat, "Mollusques nouveatux, litiggieux, ou peu comnus," I867, p. 234.

3 "British Concholory"," i. (1862), p. 20\%. 
where a thrush or blackbird had had a meal, and thus it was feared all had vanished. The Vale Castle colonists were seen by Mr. Rimmer during the summer of $1 S 73$, but they inhabited only a limited area, and numbered probably not more than a few hundreds. At Vazon Bay, the creatures seem to have clone much better, for in the summer of I876, Mr. Sherriff Tye saw "many thousands" in that locality, and the following year the colony was reported by the Rev. A. H. Cooke and the Rev. Professor Gwatkin to have extended over an area at least half-a-mile in length, and I find it stated that specimens were again collected in I $\$ 84$ by Mr. Brockton Tomlin. It is interesting to note, Mr. Cooke and Mr. Gwatkin have pointed out, that the capabilities of these colonies for sustaining life varied directly with the exposed nature of their situation: "that at Sark, on rather high and rocky ground, probably never took root at all, that at Väle Castle, in spite of its northeasterly outlook, was on far more congenial soil, and consequently survived until 1873 or later, while that at Vazon, planted on low-lying ground, and facing the north-west, has lived and flourished." "Mr. Heathcote is said to have planted this snail in considerable numbers in seemingly favourable situations amongst the Southport sandhills, but I do not know with what result; it is stated also that Mr. T. Rogers has often tried to

1 A. H. Cooke and H. M. Gwatkin, "Quart. Journ. Conch.," i. pp. 332-3; R. Rimmer, "Quart. Journ. Conch.," i. pp. 266-7; G. S. Tye, "Quart. Journ. Conch.," i. pp. 230-I ; J. W. Taylor, "Journ. of Conch.," iv. (1885), p. 275. 
colonize it, presumably in Lancashire, but has hitherto failed, owing, he believes, to the creatures having been picked up by birds.' A few turned out in the north of Scotland, near the coast, by Mr. W. Baillie of Brora, are believed to have perished during the first winter.

Mr. Baillie has experimented with several species near Brora, with considerable success. In I883, he mentioned that he had introduced into the lower part of the basin of the Brora River colonies of Hclix acuta and Helix virgata from Llandudno, $H$. cricetorum from North Sutherland, and $H$. aspersa from Banff, the first three of which seemed likely to hold their ground, but H. asperse had been lost sight of, "probably killed out by blackbirds." Subsequently, in I 887 , some of these colonies were reported to have done well; Helix acuta and Helix virgata were living in hundreds, extending northwards from the mouth of the Brora River for upivards of half-a-mile. Clausilia paroula, which had been introduced from Normandy, seemed to hold its ground. Clausilia laminata, Cyclostoma elegans, and a few specimens of $H$. pisana, $H$. cantiana, and $H$. mefescens had also been turned out." In October, IS9I, Mr. Baillie had the kindness to furnish me with a few additional notes; the $H$. virgater colony, he stated, was the most promising, the creatures having increased near the sea to thousands. $H$. acuta, which had prospered for some time, had apparently died out.

'R. Standen, "Nat.," I 887. p. 176.

" II. Baillie, "Journ. of Conch.," iv. (ISSt), p.160; v. (1887), p. 192. 
II. crictomm had increased to a considcrable extent; H. aspersa, also, had survived and had become so numerous in his garden that hundreds had been transplanted to different parts of the East Sutherlandshire coast during the preceding summer. H. cantiance and H. mescens had done well, and Clausilic paroula was still alive, as also in all probability were Cl. Laminate and Cyclostoma elegans. Living specimens of Clausilia biplicate from the banks of the Thames, Clausitia solida from France, and Cochlicopa tridens and Hilix pomation had also been turned out in small numbers. A number of Clausitia laminata and Clansitia rolphï from Buriton, Hants, were once turned out by the Rev. J. McMurtrie in a glen at North Berwick, Haddingtonshire, but, as was stated a few years afterwards, "it is not likely they have withstood the climate." Mr. G. B. Adami, it is said, "has tried to introduce seventeen species of land and fresh-water molluscs at Edolo, Val Camonica, from other parts of Upper Italy," of which four soon disappeared, the rest surviving. ${ }^{2}$ A number of land-shells (Hclix ?, several species) from Buenos Ayres and Montevideo were once turned out in a garden in Yorkshire, and after three or four years many were reported to be still alive and apparently healthy. It is interesting to find, as the observer remarked, that the creatures were able to withstand the rigour of our climate; one of the winters through which they passed

'J. McMurtrie, "Journ. of Conch.," vi. (1889), p. 5.

2 "Moll. terr. e fluv. di Brescia e Bergamo," I876, p. 91, as quoted in the "Zoological Record," xiii. (1876), Moll. p. 18. 
seems to have been exceptionally severe.' The successful transportal of Hclix nemoralis from England to New Jersey, and the establishment of several new colonies of the same species from an accidentally introduced stock in Virginia, have just been mentioned; Helix appressa, sent from Illinois, became well established in New Jersey in the same garden; ${ }^{2}$ Helix austriaca, according to a statement in the Zoological Record for I87I," "acclimatized scventecn years ago near Stettin, thrives there very well and multiplies considerably ;" Helix villosa from Switzcrland turned out by the Rev. Canon Tristram on a moor in co. Durham was known to be living in the same place ten years later, and Helix lapicida from the south of England planted by one of Mr. Tristram's friends on some rocks on the banks of the Wear, in the same county, ultimately became one of the recognized local shells. But Clausilice from Africa and from Syria and various specics of Helix from the latter region also turned out in the same county, being able to "protect themselves against heat better than cold," are said to have perished during the first winter; ${ }^{4}$ Helix lapicida from England, and Bulimus decollatus from Charleston, South Carolina, disappeared

'G. Norman, "Zoologist," xii. (1854), p. 4435.

2 W. G. Binney, "Terrestrial air-breathing Mollusks," v. (I878), pp. $29,306$.

3 viii. (I $\$ 7$ r), p. I 30 , referring to Dohrn, "Nachr. malak. Ges.," iii. pp. 17-1S.

"H, B. Tristram, "Zoologist," (3), i. (1877), pp. 260-I. 
at once in Mr. Binney's garden ; Helix hortensis from the island of Martha's Vineyard, "of course introduced from Europe," could not be established by Mr. J. H. Thomson in his garden, the young being devoured, 2 it was believed, by slugs, Limax, A rion, ctc. ;" thirty or forty specimens of the same species once placed in a hedgerow in this country, in the neighbourhood of Upton, were never afterwards seen; ${ }^{4}$ a large number of Helix virgata from various localities turned out near Chislehurst did not "seem to multiply," and many specimens of Helix cartusiana from Sandwich liberated in the same neighbourhood are believed to have died out. ${ }^{5}$

Slugs, I suppose, have not been much dispersed intentionally. Half a dozen Testacella from the Isle of Wight once turned out by Mr. W. Jeffery in his garden appear to have been lost sight of; a single quartergrown individual, however, is said to have been detected

' W. G. Binney, "Terrestrial air-breathing Mollusks," v. (IS78), 379 .

2 With reference to this statement it may be interesting to notice that in Charleston, S.C., a foreign snail, believed to be Helix nemoralis, formerly existing there in great numbers, was completely exterminated by Bulimus decollatus, also a foreign species, at least so the elder Binney was informed on what was considered good authority, but, as he admitted, the destruction of the one species, though subsequent to the introduction of the other, might not have had any connection with it. A. Binney, "Terrestrial air-breathing Mollusks," i. (I 5 I ), p. I 34.

3 J. H. Thomson, "Journ. of Conch.," iv. (1 885), p. 373.

4 I. Byerlcy, "Proc. Lit. and Philos. Soc., Liverpool," I 854 , p. 47.

: T, D. A. Cockerell, "Journ. of Conch.," iv. (I884), p. 238. 
after about a year.' Mr. Baillic tells me that he put down a few specimens of Amalia marginata in his garden-in Sutherlandshire-about nine years ago, but nothing has been seen of them since.

We have now to inquire as to the means by which molluscs may have been unintentionally dispersed by man's agency.

\section{Fresh-WATER Shells.}

Aquatic shells and their ova-no doubt less frequently dispersed by man than terrestrial kinds-seem likely to have been occasionally carried with cargoes and consignments of various sorts. One species now flourishing in this country, as we shall sec, is believed to have been imported attached to timber in the holds of ships, and another is supposed to have come from America in cotton bales. Our Limnea strgnalis, it is suggested, was introduced into Tasmania, I presume unintentionally, with fish-ova." Many kinds, both ova and adults, must certainly have been carried from place to place, even to great distances and from one country to another, along with consignments of plants, but I am not aware that the creatures are ever actually noticed by those whe unpack such consignments; several facts, however, clearly indicating transportal in this way might be given. Thus, for instance, Mr. W. W. Westgate of Houston, Texas, once found his water-lily tubs, in which plants from Fayette County, Texas, and from Florida were

' W. Jeffery, "Journ. of Conch.," iii. (I882), p. 3 I 3.

"W. F. Pettard, "Journ. of Conch.," ii. (1879), p. 81.

O 2 
growing, "filled with Physa gyrina Say" of a different form from those found in his neighbourhood ; ${ }^{1}$ and some years ago, Dr. Alford Nicholls found fresh-water shells of two species inhabiting tubs in which he was cultivating aquatic plants, gathered some time previously in a pond in the island of Antigua, and carried from thence to Dominica. The digging of canals, of course, as Forbes long ago remarked, has largely facilitated the spread of these animals." In America and in other large land areas, it will be remembered, "the waters of streams which differ widely in their faune " are sometimes thus connected. ${ }^{3}$

\section{LAND-SHELLS.}

It seems likely that land kinds are frequently carried in ships' ballast, collected, as it often is, near the shores of one country and discharged on those of another. Dr. Binney in a discussion on the introduction of foreign species into the United States referred to this cause as a "common mode of introduction;" " and at least three species which have occurred alive in England are believed to have been thus imported. Discoveries of living shells in freshly discharged ballast would be of much interest, but I am not aware that any records of the kind have been made. Miss Esmark mentions

'W. W. Westgate, "Conchologists' Exchange," ii. ( 1888$),$ p. 98.

2 Edward Forbes, "Mem. Geol. Survey of Gt. Britain," i. (I 846), p. 398 .

3 W. B. Marshall, "Nautilus," v. (1892), pp. 133-4.

4 See "Terrestrial air-breathing Mollusks," i. (I851), p. I 5 I. 
the occurrence of "a well conserved shell of Helix asperse in some imported sand near Langesund." A shell of Helix ericetorm once found near Christiania, this author suggests, may have been imported "among sand brought with vessels from England or France." It seems almost certain that the creatures are occasionally carried many miles with railway ballast, with chalk, etc., used in making sea defences and other embankments, with earth and other substances transported for horticultural purposes, etc. Thus the Kentish snail (Helix cantiana), abundant on railway-banks near Hartlepool, "may have been introduced in ballast ;" 2 Helix virgate, found plentifully on embankments between Pevensey and Bexhill, where the London, Brighton and South-coast Railway runs close to the sea, was probably brought, as the Rev. S. Spencer Pearce states, with the clialk forming the embankments, which is believed to have come from the Eastbourne cutting, some eight or nine miles away; the same snail, according to another observer, noticed in several places on railway-banks also in Sussex "was probably brought with chalk ;" a colony of Helix cartusiana, also, known to have existed for some years at Cowfold, in the same county, and now extinct, is believed to have been originally introduced with chalk. ${ }^{3}$ Helix virgato,

'B. Esmark, "Journ. of Conch.," v. (IS86), p. Io6.

2 "Naturalist," 1886, p. 148, quoting J. E. Robson, "Young Nat.," v. (I884), p. 192.

3 W. Borrer, cited by J. E. Harting, "Zoologist," (3), ii. (I 878 ), p. 92. 
abundant along the promenade at Southport, and only observed there in recent years, is "supposed to have been imported with the building materials," and the same species, to give another case, established in gardens, now disused and weed-grown, around some of the Martello Towers in the midst of the broad shinglebeach, which, of course, is destitute of terrestrial molluscs, between Eastbourne and Hastings was probably introduced, Mr. Pearce suggests, with the chalky soil of which the little plats were formed, or it may have been carried thither with garden plants.

That the creatures have been widely dispersed along with plants, shrubs, etc., now so frequently sent from one country to another, cannot be doubted for a moment; unconsciously horticulturists have probably done more than any other class of persons to mix the aboriginal faunas of distant countries, and doubtless transportal in this way for short distances is constantly taking place. Wardian cases, as Mr. Layard remarks to me, must certainly be great factors of dispersal, and living snails are known to have been transported with quite small consignments of plants, in the earth at their roots, and even with "dry-bulbs" transmitted with little or no earthy matter. Foreign snails, and others evidently from a distance, are rell known to turn up every now and then in greenhouses: during I 883, Mr. Musson procured three foreign species, probably South American,

' H. H. Higgins, "Address to Liverpool Nat. Field Club, January 3oth, 1891," p. 24; the creature occurs also near Southport at Moels Cop Road. 
two of them occurring plentifully, from Mr. Thacker's orchid-house in Nottingham, and many similar finds might be instanced; one exotic species, in fact, is now well established in greenhouses, cucumber-frames, pinebeds, etc. in many parts of this island. Mr. Heathcote is said to have taken some splendid specimens of Hyalinia draparnaldi-apparently unknown as an indigenous species in Lancashire-in his greenhouse at Preston in that county. Mr. Standen mentions having discovered one in his fernery at Swinton near Manchester; it had probably been transported with some ferns sent to him by Mr. Heathcote. It is interesting to find that the creatures have been actually noticed among imported plants: thus Mr. Gude recently showed me a living shell of Helicina amana, found by one of the employés at Messrs. Williams' nurseries, Upper Holloway, in a case of orchids (Cattleya citrina) which had just arrived in a dry state from Mexico, and it is perhaps worth mentioning that a living snail (Helix nemoralis or hortensis) has been received at the same nurseries in a consignment of Sphagnum-moss from Essex. To give another instance: a Bulimus-snail, possibly Subulina striatella, was once found in Madeira by Senhor J. M. Moniz amongst some plants received by him from the island of St. Thomas in the Gulf of Guinea; and on another occasion, three dead shells believed to belong to the same species, foreign to the Madeiran Archipelago, were found in an old bone,

1 R. Standen, "Naturalist," I 887, p. 176. 
in a garden near Funchal.' Helix acuta is said by Kobelt to have arrived alive in gardens at Frankfort on palm-trunks." The Lexington colony of Helix nemoralis, according to Professor Morrison, probably sprang from specimens imported "in earth, in flowerpots," ${ }^{3}$ and many facts proving such transportal are likely to have been observed in different parts of the world. Thus-to give the only instances with which I am acquainted-during Sir C. Lycll's stay in Madcira no less than three species of Portuguese snails (Helices) were found in the carth of a single flower-pot in which a garden plant had been sent from Lisbon ; ${ }^{4}$ and several specimens of Pupa umbilicate were once found alive, together with a specimen of Clansilia mgosa, in the mould around some ferns received by Mr. Musson at Nottingham from Derbyshire. The eggs of many kinds, seemingly specially suited for dissemination in these modes, are probably carried much more frequently than the adult animals, but from being comparatively inconspicuous and often buried in soil or concealed about the roots of plants they are not likely to be often noticed.

"T. V. Wollaston, "Testacea Atlantica," I878, p. 205.

2 "Zoological Record," vii. (I870), p. I30, referring to Kobelt, "Nachr. mal. Ges.," ii. p. I6o.

3 H. A. Pilsbry, "Nautilus," iii. (rSS9), pp. 51-2.

4 "Principles," ii. p. 427; and see a letter from Lyell to Bunbury, dated in 1856 , referring to Madeira : "a friend of Wollaston received a flower from Europe in a pot very lately, and found five species [sic] of European helices alive, buried in the mould." "Life, Letters and Journals of Sir C. Lyell, Bart.," ii. (I881), p. 209. 
Cargoes and consignments of vegetable productions, other than those intended for horticultural purposes, secm likely also to have served occasionally as means for dissemination. Thus in a recent cnumeration of Morocco shells mention is made of the finding of Helix dehnii amongst gum arabic; Helix vermiculata, as we shall see in the next chapter, has been found alive in a parcel of chemist's horehound ; ${ }^{2}$ and living specimens of Helix caperata have been discovered amongst screenings from barley intended for malting; we find, too, that several specimens of a forcign snail were once discovered alive in a garden into which a quantity of such screenings had been imported. ${ }^{3}$ Dead shells of Helix alauda, a species belonging strictly to the fauna of Cuba, have been found on one or two occasions among bananas in Boston, Mass., and a living specimen once found in a grove in Rhode Island was probably introduced, as Mr. John Ford has suggested, with a bunch of those fruits. ${ }^{4}$ The importation with dye-wood from Brazil of two specimens of Bulimus largillierti has been noted somewhat recently in the "Nachrichtsblatt der deutschen malakozoologischen Gesellschaft ; " and living specimens of Bulimus undatus, adhering to tropical timber, are said to have been imported into

' "Zoological Record," xvii. (I880), Moll., p. 24. referring to "J. de Conch.," xxviii., pp. I- 83 .

"Proc. Conch. Soc., "Journ. of Conch.," vi. ( I S9I). p. 393.

${ }^{3}$ P. B. Mason, "Journ. of Conch.," iii. (I8So-2), p. IIS.

" J. Ford, "Conchologists' Exchange," ii. (I 887), 7 I-2.

s O. Boettger, "Nachr. mal. Ges.." xviii., p. 58, as quoted in "Zoologicall Record," xxiii. (ISS6), Moll., p. 6r. 
Liverpool; indeed, Sir C. Lyell was even informed by Mr. Broderip that the species was naturalized in the woods near that city! ${ }^{1}$ Dr. Stearns has referred also to the conveyance of Bulimi of two species to San Francisco in a cargo of dye-woods from the Gulf of California; he states:

"The dye-woods had been hauled from the place where they were cut, and piled up near the embarcadero on the gulf shore, and afterwards transferred to the vessel. These snails had crawled into the hollows and crevices of the wood, and were discovered when the cargo was unloaded and put on the wharf in San Francisco. When the sticks were thrown ashore the rough handling shook out the snail-shells; many also were found in the hold of the vessel after the cargo was discharged."

Unfortunately in this case, however, none of the several specimens obtained by Dr. Stearns were alive. ${ }^{2}$

Foreign shells, it is curious to find, have even been shipped to this country with cattle-bone. Mr. G. Norman, of Hull, it appears, once "procured a great number of Jiving mollusca (apparently several species of Helix) from a vessel recently arrived with cattle-bone from Buenos Ayres and Montevideo, in the cargo of which they abounded," and many turned out in a garden, as just mentioned, lived for several years."

1 "Principles," ii., p. 37I ; and compare Gray's "Turton," 1857, P. 292.

${ }^{2}$ R. E. C. Stearns, "West American Scientist," vii. (1891), p. 108 .

${ }^{3}$ G. Norman, "Zoologist," xii. (1854), p. 4435. 
The use of some land molluscs for food and for medicinal purposes has doubtless conduced to their dissemination. Thus, for instance, Bulimus (Placostylus) edzeards. ianus, an outlier of the $B$. fibratus group, is believed by Mr. Layard to have been introduced into New Caledonia from the Loyalty Islands during the native wars, the animal having been used as food by the Loyalty Islanders and probably carricd over by them when they landed to fight the New Caledonians. European kinds, as everyone knows, constitute an important part in the live stock of many ships, between seven and eight thousand of Helix aspersa, as Tate states, for instance, forming part of the provisions of a ship leaving the port of Bordeaux for a long voyage. ${ }^{1}$ As is well known, also, the creatures are sometimes exported to distant countries as delicacies, and they travel well, according to Gray, in old casks, fixing themselves on one another round the circumference and leaving a vacant space in the centre.' As stated by Dr. Binney, the larger European species, and particularly Helix aspersa, are sometimes imported into the United States, for use as food by foreign residents. ${ }^{3}$ Now and then, doubtless, from some cause or other, a few manage to escape near scaports, or after arriving at their destinations further inland, and many colonies have almost certainly been established in this way. Portuguese sailors, with whom

'R. Tate, "Land and Fresh-water Mollusks," (1866), p. I 16.

"Gray's "Turton," 1857, p. 105.

3 A. Binney, "Terrestrial air-breathing Mollusks," i. (I851), p. 151 . 
snails are much in favour as "live sea stock," according to Woodward's "Manual," have naturalized "Helix aspersa in Algeria, the Azores, and Brazil, and Helix lacter at Teneriffe and Montevideo." "H. lacter is said to be extremely common in the markets at Buenos Ayres." Occasionally, as might be supposed, imported edible snails are intentionally thrown out in the hope that they may establish themselves. Ifclix pomatio, as mentioned in the next chapter, is said by some authors to have been thus established in England by the Romans, and others say that it was subscquently planted by our own countrymen who had imported it either as a delicacy or for medicinal uscs. Mr. Layard assures me that Helix aspersa, now abounding about Cape Town, first obtained a footing in this manner. The following cxtract from a characteristic letter of his -dealing also with the introduction of the creature into the Loyalty Islands-will be read with interest:

"In I 854 (or I 855 , I am not sure which) I was living in the 'Gardens,' that part of Cape Town running up the slope of Table Mountain. I one day noticed in the vincyard attached to my house, on a wall, a cluster of young $H$. aspersa. Of course I knew at once they must be an introduction. Soon complaints were made of vines and vegetables being devoured by snails, and as I was known to be a "snail collector," the introduction of the marauder was set down to me. This I at once repudiated, and set to work to find out who had

\footnotetext{
1 Woodwari's "Manual," ed. 4, rep. I890, p. 87.

" IV. H. Rush, "Nautilus," vi. (1892), p. 82.
} 
done it. I discovered that some months previously a French man-of-war had been in the harbour and having received much kindness and attention from the French Consul, Mons. D., had requited it somewhat by presenting him with a little barrel of "cscargots" of which he was very fond. Mons. D. was a wise man! He reasoned within himself, "I can both have my cake, and eat my cake; I'll eat the big ones and plant the little ones." So "whene'er he took his walks abroad" he took a few little ones with him, and chucked them over the garden walls; and they increased and multiplied and filled the land, and in the words of the old writer (slightly altered)

Mons. D. bred the bore

But E. L. L. got the 'gloire' !

"In 1879 , I was on a collecting trip to the Loyalty Islands. I was living in the house of a trader named Wright at Chepenche, in the island of Lifou. The natives, of course, discussed me and my doings, how I shot and skinned birds and picked up shells. One day a native came, and addressing Wright, said he had brought a shell that no native of the island had ever seen before; he had found it in his Yam patch, and hoped I would give him a good reward for it. After this oration he carcfully unticd the corner of his waist-cloth, and produced a bundle of Yam leaves, carefully tied up ; in the centre of these was a half-grown H. aspersa! Wright examined it with great care. He had never seen anything like it before (he was born in Australia) 
and he knew the shells of the country pretty well. Had I ever scen it? I told him I had, rather ! and I told him and the native the mischief they would do, and the intruder, being condemned to death, was promptly "crunched" under my foot. Then came the question, how got it there? I told Wright how it got to the Cape, and went off in a spirit of inquiry (seasoned with diplomacy) to Mons. Luguier the French chief official, or Résident as he is called; a little manœuvring brought round the question, did he like escargots? "Ah, yes!" and he had lately had a stroke of luck; a French man-of-war had called in and given him a nice lot of them; he had eaten the large ones and had distributed the small ones about the place, and when they grew bigger and had large families, he would always have a dish at command. So thus the introduction of the pest into two widely remote countries is most distinctly traced to French men-of-war."

\section{SLUGS.}

The naked molluscs, as Mr. Hedley remarks to me, seem to have roamed further and faster than shellsnails; in their race to the antipodes, at least, as recently pointed out by him, European kinds "have far outstripped their shell-bearing relatives," "and this is certainly a surprising result, for, as we have seen, the creatures clearly seem less fitted than snails for accidental dispersal under nature. In all probability, how-

${ }^{1}$ C. Hedley, "Ann. and Mag. Nat. Hist.," (6), ix. (1892), p. I7o, 
ever, they have been widely scattered by man, being carricd, no doubt, for the most part, along with consignments of plants, shrubs, etc. Many kinds, indeed, secm cminently suited for such transportal; of Testacella haliotidea, for instance, Mr. Jeffrcys writes :

"A usual habitat of this kind of Testacella is at the roots of flower-plants, or under heaps of dead leaves in gardens; and if a plant were imported into this country from the botanic garden at Montpellier with the native soil or a compost made of lcaf-mould, cither the snailslug or its eggs would perhaps accompany it." 1

The presence of T. mange $i$ in this country is usually attributed to transportal with plants. Many kinds must annually travel in safcty from one country to another in Wardian cases, etc. Observed facts proving dispersal in this way, however, are probably scarce, but this is explained perhaps by the fact that the creatures, probably travclling chiefly as ova, are not likcly to be often noticed. Tasmanian specimens of the great grey slug (Limax maximus) have been observed to be infested with an acarus, and if this proves to be identical with the European parasite, the fact will argue, as Mr. Hedley remarks, that the animals migrated in the aduit rather than in the egg statc. ${ }^{2}$ The United States National Museum, it is interesting to find, once "received a specimen of the peculiar slug Veronicella which had been found by the giver in a bunch of bananas;" 3 and

1 "British Conchology," i. (1862), p. I46.

"C. Hedley, "Ann. and Mag. Nat. Hist.," (6), ix. (1892), p. r7o.

${ }^{3}$ R. E. C. Stearns, "West American Scientist," vii. (1891), p. 108. 
it is worthy of notc also that a couple of "splendidly grown Parmacclla "- -slugs forcign to our fauna-no doubt introduced accidentally with plants, are said to have been detected on one occasion in a garden near Newcastle. ${ }^{i}$

'H. B. Tristram, "Zoologist," (3), i. (1877), pp. 260-1. 


\section{CHAPTER IX.}

ON THE FRESH-WATER AND LAND MOLLUSCA IN TRODUCED INTO THE BRITISH ISLES BY HUMAN AGENCY.

MAN's agency, as Forbes long ago remarked, "may materially affect a fauna, and has affected that of Britain." $\quad$ Of the forty-six fresh-water species included in the Conchological Society's list of ISS3, however, only two, the zebra mussel (Dreissena polymorpha) and an American coil-shell (Planorbis dilatatus), can be reasonably regarded as human importations; and, as far as I know, only one other, Spharium ovale, has ever been looked upon as even doubtfully indigenous.

Spherium ovale, which is local in this country, happens to occur in company with Planorbis dilatatus in canals at Gorton, Pendleton, ctc., so that Mr. Jeffreys was led to suggest, in I 869, that it might possibly be the $S$. trinsiersum of Say introduced, like $P$. dilatatus, from Ancrica; but he observed that it had long been known in this country, and that he possessed a specimen which was in Dr. Turton's collection of British shells more

'Edward Forbes, "Report, gth meeting, British Association, IS39," (I 840$)$, p. I 30. 
than forty years previously.' It has been further suggested that shells regarded as pertaining to a form of Planorbis slaber Jeff., found associated with $P$. dilatatus in a water-lodge at Burnley, may be Say's $P$. paruns also introduced from America; P. slaber, however-often regarded as identical with $P$. parvusthough local, ranges widely in Europe, extending in this country "from the Shetland Isles to Land's End," and its right to rank as a native is not doubted."

A short account of what is known of $D$. polymorpha and $P$. dilatatus in Britain, and of the manner in which they were probably introduced, may be of interest ; and it is worth while, perhaps, to add a note on an exotic pondsnail, Physa acuta, which, though not referred to in the Conchological Society's list, is known to live, under artificial conditions, in two localities in England, and one in Scotland, and has in all probability been introduced unintentionally by man.

Dreissena polymorpha Pall. On 2nd November, I 824, the Linnean Society, as appears by an extract from their minute-book, received from Mr. J. De C. Sowerby, specimens of a fresh-water shell, "probably the Mytilus polymorphus Gmel., 3363," which had been found in abundance, attached to shells and timber, in

' J. G. Jeffreys, "Ann. and Mag. Nat. Hist.," (4), iv. (1869), pp. 34I-2 ; and see also W. C. Hey, "Journ. of Conch.," iii. (I882), p. 271 ; T. Rogers, "Journ. of Conch.," v. (1887), p. 220 ; R. Standen, "Naturalist," I 887, p. I 57.

${ }^{2}$ T. Rogers, "Journ. of Conch.," v. (1887), p. 219; Jeffreys, "British Conchology," i. (1862), p. S6; Rimmer, "Land and Freshwater Shclls," I8So, p. 40. 
the Commercial Docks, in the Thames, by James Bryant, Esq., who was in the habit of using the animal as a bait for perch-fishing, and this is the first mention of the cxistence in Britain of the now common and widely distributed $D$. polymorpha. In a letter accompanying the shells, Mr. Sowerby suggested that the specics, which was known in the Danube and in the rivers of Russia, had probably been imported into this country with timber, and in the following year Mr. Gray expressed a similar opinion, believing the creature to have been brought with timber from the Volga, and further pointing out that it was able to live for a long time out of water, he having thus kept one in health for three weeks. As some molluscs attach themselves to the bottoms of ships, Sir C. Lyell was led to suggest that the present species might have been introduced in this way, and it was explained by Mr. Garner that by keeping the valves constantly closed it was perhaps able to survive immersion in salt-water during the voyage. It is much more probable, however, that the creature was imported with timber as suggested by Sowerby and Gray, and this was afterwards admitted by Lyell himself. A friend of Gray's is said to have seen the animals sticking to Baltic timber, which had not been unloaded, and was still in the ship's hold. ${ }^{1}$

1 "Trans. Lin. Soc.," xiv. (1825), p. 585 ; "Ann. Phil.," (n.s.), ix. (IS25), p. 226 ; “Zool. Journ.," i. (IS25),p. 5 S4 ; J. E. Gray, "Ann . Phil.," (n.s.), ix. (1 S25), p. I39; Lyell, " P'rinciples," ed. 9, ( I S53), p. 652; R. Garner, Charlesworth's "Mag. Nat. Hist.," (n.s.), iii. (I 89), pp. 302-3; (iraty's "T'urton," I857, p. 262. 
In the "British Conchology," in I S62, Mr. Jeffreys expressly inclined to a belief that the creature ought to be looked upon as a native of Britain, and of the whole of the North of Europe, adding that if, as he believed, "the indigenousness of the Dreissend as regards this country should hereafter be established, the ingenious theorics which have been put forward to account for the mode of its transport across the seas will not require further discussion." The circumstance of its not having been noticed here before I 824 , and then only in a metropolitan locality, he remarked, did not preclude the possibility of its having previously existed in some other part of the country, its not having been previsusly recorded as British rather proving a want of observation or opportunity than its non-cxistence. As tending to confirm this belief, he pointed out-that Helix cartusiand, H. obvoluta and Clausilia rolphii, "all of which are conspicuous land-shells," were unknown to the obscrvant Montagu, although not uncommon in some parts of this country, and clearly indigenous, and many similar instances might be cited, he said, on this point, as well as with respect to the sudden and unaccountable appearance and disappcarance of certain species in particular spots: that the Pinne fuviatilis of Sander was doubtless our Dreissenc, which was therefore found in the interior of Germany before $\mathbf{I} 780$, inhabiting streams which flowed into the Rhine: that in draining the Lake of Haarlem, which apparently never communicated with any port or harbour, it was found in abundance, and it had been discovered, also, in an 
inland lake near Copenhagen; that, finally, it had been recorded by M. Charles D'Orbigny as one of the fossils occurring in an upper tertiary deposit in the north of France, and on this ground he (Jeffreys) was not without hope that it might be discovered in the corresponding strata in this country.' From various considerations, however, this idea that the creature had always existed in Britain, and had been accidentally overlooked by all our naturalists previously to I 824 , seems to me in the highest degree improbable. The "British Conchology" has long been a standard hand-book, and the views of its author have largely influenced the minds of those who have attended to the mollusca, but the very general impression that $D$. polymorpha is a foreign importation has not been dispelled. There must be good rcason for supposing it to have been introduced, otherwise I cannot think that this vicw, put forward by Mr. Sowerby in I 824 , would have been endorsed by Gray in 1825 , by Fleming in 1828 , by Berkeley in 1836 , by Alder and Strickland in 1838, by Captain Brown in I844, by Forbes and Hanley in 1853 , as well as by Woodward and nearly all other writers, even including Reeve, Tate, and Harting, whose works were issued subsequently to the date of the volume in which $\mathrm{Mr}$. Jeffreys' views were expressed. With regard to Helix cartusiana, H. obvoluta, and Clausilia rolphii, the three "conspicuous land-shells" mentioned by Jeffreys as clearly indigenous yet unknown to Montagu (who published his "Testacca Britannica" in I 803), it must be

'J. G. Jeftrey's, " British Conchology," i. (1862), pp. 47-50. 
remarked that they are all local species, and their presence in this country can hardly be said to be conspicuous, for an observer, unguided by published records, might well collect for years, or for a life-time, without finding them, while on the other hand, $D$. polymorpha is "so gencrally distributed that it cannot fail to attract the attention of the collector." " Dr. Mörch, it is true, has argued that there is no reason for supposing the creature's non-cxistence in the west of Europe previously to I824, maintaining that it is Sander's Pinnafluviatilis, but eminent conchologists have denied that this is the casc." In the crrata given at the end of his volume, Jeffreys corrects the statement respecting the specimen referred to by D'Orbigny, which, it appears, was recent, not fossil. The animal is known, however, to have occurred anciently in North Germany, in the diluvium of East and West Prussia, etc., but it is there supposed to have been driven away, by unfavourable climatic conditions or otherwise, and to have subsequently regained its former range by immigration. ${ }^{3}$

This species has frequently been referred to as illustrating the rapidity with which a mollusc may become naturalized and diffused over a large area, and it is even said to flourish in this country, under certain conditions, greatly in excess of any native form. ${ }^{4}$ In

1 Harting's "Rambles," 1875, p. 41.

"See O. A. L. Mörch, "Ann. and Mag. Nat. Hist.," (3), xix. (1867), pp. 82-4.

3 See "Ann. and Mag. Nat. Hist.," (6), ix. (1892), p. I6o.

"See H. H. Higgins, "Address to Liverpool Nat. Field-club, 30 January, I 89 I," p. 7. 
I 838, Mr. Strickland pointed out thä it multiplied with astonishing rapidity, and, in a few years, he thought, it would probably become one of our commonest molluscs. On visiting the Commercial Docks, the original British habitat, in or about that year, he saw a vast number of the shells in the depot for bonded timber; at least one generation, evidently, had passed away since the introduction, for dead-shells were scattered over the bottom and served as points of attachment for the byssi of the living; it would be interesting, he remarked, to watch the gradual spread of the species over the kingdom.' About the years $\mathrm{I}_{3} \mathrm{I}-3$, we find, it was discovered in great numbers at Goolc, Yorkshire, in docks belonging to the Aire and Calder Company, opened only three or four years previously. On the water being drawn off a few fect lower than usual, the walls were seen to be "completely covered" with shells, pecks of which might have been procured. One of the docks was used entirely for the bonding of foreign timber which frequently remained there for some months before being re-shipped or floated upon rivers and canals to various inland towns, and during such periods, it is said, those pieces which adjoined the sides or touched the bottom were sure to become covered with shells, which, thus, might easily be carried to the various districts communicating with the canals of the Aire and Calder Company." About this

' H. E. Strickland, Charlesworth's "Mag. Nat. Hist.," (n. s.), ii. (1 $\left.s_{3} 8\right)$, pp. 362-3.

"R. J. Bell, "Zoologist," i. (I 843 ). p. 253. 
time, also, it was observed in Scotland, where, as mentioned by Dr. J. Scouler of Glasgow in 1833 , it was found living in vast abundance towards the eastern extremity of the Clyde and Forth Canal; and, in the following year, its discovery in the Union Canal, near Edinburgh, was communicated to the Wernerian Society by Mr. Stark.' In I836, the Rev. M. J. Berkeley found the species in plenty on the piers of a bridge crossing the Nen at Fotheringhay, Northamptonshire, and also, a little higher up the same river, on the stones of a small overfall at Tansor. He had formerly examined the stream carefully, for several successive years, both above and below these spots, without detecting the creature, and had reason to believe that its establishment was of recent date (subsequent to 1828 ) ; probably, he thought, it had been introduced from Wisbeach on timber. ${ }^{2}$ As to the date of its detection at the last mentioned place I know nothing. In I837, Mr. Strickland discovered it in the Avon, near Evesham, in Worcestershire. From I 828 to I 834 he was in the habit of conchologizing frequently in that river, and could scarcely have failed to detect the creature if it had then lived there, but none occurred. In 1837 , however, after an absence from England of two years, he was greatly surprised on finding several of its shells among

1 J. Scouler, Loudon's "Mag. Nat. Hist.," vi. (1833), p. 532 ; Stark, as quoted by Berkeley, Loudon's "Mag. Nat. Hist.," ix. (1836), p. 572 .

2 M. J. Berkeley, Loudon's “Mag. Nat. Hist.," ix. (I 836), pp. $572-3$. 
refuse on the banks of the river, and on further search he found that the animal had become completely established on the gravel of the river-bed; several hundred fullgrown specimens were collected in the course of an hour; "there is, therefore, clear evidence of the recent introduction of this molluse into the Avon, and of the rapidity with which it has reached maturity and multiplied." In the same or the following year, Mr. Strickland observed the species in the canal between Warwick and Birmingham, and, in a paper dated in I838, he stated that it had been found also in the canals near Wednesbury, in Staffordshire, and in the Leam at Leamington; the latter water is not navigable, but is near a canal from which the Dreissena was probably introduced. In the same paper Mr. Strickland stated that the animal had been "planted" in some of the waters near Bristol." About I838, also, it was detected in the Lesser Nen, which runs through the town of March, ${ }^{2}$ and about the same time a specimen was obtained in Nottinghamshire from unnavigable water-an old mill-dam at Toton, supplied by the Erewash, a small shallow stream joining the River Trent nearly a mile from the place-that river being the nearest navigable water; afterwards (before r 846) numbers were found "adhering to stones underneath the water-fall of a pond at Lenton" in the same county, to which they must have gone up a very small brook

'H. E. Strickland, Charlesworth's "Mag. Nat. Hist.," (n.s.), i. (1 338$)$, pp. $361-3$.

"S. Smith, "Science Gossip," for 1868, p. 238. 
fully a mile from a canal, where, however, though the observer had frequently searched, he had never found them.' The animal was known to occur in streams near Exmouth, in I842. By 1843 it is said to have found its way to various canals and other waters in Leicestershire, and it had been discovered in immense numbers in the Grand Trunk Canal at Burton, Staffordshire. ${ }^{2}$ Captain Brown, in $\mathrm{I} 844$, stated that it was common in the Bridgwater Canal, and also "in many places in the canal betwixt Manchester and Hull," and in that year it was noticed, also, on timber in the Ouse, near St. Neots, Huntingdonshire." We find, therefore, that within twenty years from the announcement of its discovery $D$. polymorpha was known in two localitics in Scotland, and in England in the counties of Surrey, York, Northampton, Worcester, Warwick, Stafford, Cambridge, Nottingham, Devon, Leicester, Somerset, Huntingdon, and perhaps also in Lancashire, and it is of course probable that its range at that time may have been much wider, for I have not made a thorough search for records; indeed, if a statement by Brown ( I 444 ) is to be relied upon, it was then to be "met with in most of our canals." It would be interesting to ascertain the creature's range at the present time, but to find, and search, all the local lists and notes

'G. Wolley, "Zoologist," iv. (I 846), p. I420.

" L. M. Pratten, "Science Gossip," for I868, p. IS9 ; E. Brown, "Zoologist," i. (1843), p. 255.

3 T. Brown, "Illustrations," ed. 2, (1844), p. 76 ; C. Prentice, "Zoologist," v. (1847), p. 1651. 
which have been published would be a tedious undertaking, and might occupy the greater part of a lifetime! According to a "census of the authenticated distribution of British land and fresh-water mollusca," " published in IS89, it appears that specimens collected in the following English and Scottish counties, or vicecounties, have passed under the examination of the Conchological Society's referees :

$\begin{array}{ll}\text { Somerset, North. } & \text { Staffordshire. } \\ \text { Surrey. } & \text { Shropshire. } \\ \text { Middlesex. } & \text { Leicestershire. } \\ \text { Berkshire. } & \text { Nottinghamshire. } \\ \text { Oxfordshire. } & \text { Derbyshire. } \\ \text { Cambridgeshire. } & \text { Cheshire. } \\ \text { Huntingdonshire. } & \text { Lancashire, South. } \\ \text { Northamptonshire. } & \text { Yorkshire, South-West. } \\ \text { Gloucestershire, East. } & \text { Yorkshire, Mid-West. } \\ \text { Gloucestershire, West. } & \text { Renfrewshire. } \\ \text { Worcestershire. } & \text { Lanarkshire. } \\ \text { Warwickshire. } & \end{array}$

No Welsh or Irish habitats are given.

The Dreissen is perhaps better fitted for dissemination by man and subsequent establishment than any other fresh-water shell; tenacity of life, unusually rapid propagation, the faculty of becoming attached by a strong byssus to extraneous substances, and the power of adapting itself to strange and altogether artificial surroundings have combined to make it one of the most

1 By J. WV. Taylor and W. D. Roebuck, forming chapter v. of the volume on "Land and Freshwater Shells," in Swan Sonnenschein's "I Young Collector" series, I 889. 
successful molluscan colonists in the world. The floating of rafts of timber for commercial purposes from place to place upon rivers and canals has doubtless greatly facilitated its dispersal, and it may frequently attach itself to the bottoms of canal-boats; possibly, also, from having free-roving larvæ which live on the surface for a time, it possesses considerable facilities for dispersal independently of man, and, as just mentioned, it has found its way, in this country, to unnavigable water; every naturalist, the Rev. J. Dalton has observed, can "cite examples of Dreissenc polymorpha turning up profusely in waters where it had hitherto been unknown, and whither its progress could not be traced." I The creature is able to seize quickly upon new and unoccupied water, and this must have greatly aided it in the struggle with other forms. As already noted it was found in immense numbers in new docks at Goole within three or four years after they were opened. Some time ago, a canal near Northampton was diverted by a railway company, and after three or four years the stones forming the new banks were found to be entirely covered with the shells of this species. ${ }^{2}$ In the neighbourhood of Gloucester, also, it is said to have appeared within a few years after the opening of the Gloucester and Berkeley Canal, and to have subsequently increased greatly, so as to almost line the banks, from the edge of the water to a considerable depth, from

1 J. Dalton, "Zoologist," xix. (I86r), pp. 731 8-9.

" W. D. Crick, as cited by Taylor and Roebuck, "Journ. Northants. Nat. Hist. Soc.," iii. (I885), p. 212. 
one end of the canal to the other, a distance of sixteen miles. ${ }^{1}$

Planorbis dilatatus Gould. This American mollusc was first detected in the British Isles, and indeed in Europe, during the summer of 1869 , in the Bolton Canal, at Pendleton, on the west side of Manchester, and in the autumn of the same year it was discovered also in the Gorton Canal, on the east side of the city, the two localities being about five miles apart. In both cases, the shells were found close to cotton-mills, where the waste from the cleaning or blowing machines was ejected over and about the canals-a good deal finding its way into the water - and where the warm water from the engines was discharged. Mr. Thomas Rogers, the discoverer, and Mr. Jeffreys, who determined the species, suggested that the animal, or its eggs, had been imported from America with cotton, and it was pointed out that the best cotton is cultivated in river-bottoms, and that the crop, when picked, is spread out to dry. We have already seen that many molluscs possess great tenacity of life, and, as mentioned by Mr. Jeffreys, certain species of Planorbis, in times of adversity, close the mouths of their shells with an epiphragm, and thus protected they keep alive out of water for weeks and even months; so that it may be assumed that in all probability living specimens of $P$. dilatatus could survive a voyage from America to England; and after examining the waste from the machines,

'R. Tate, "Land and Fresh-water Mollusks," I 866, p. 23. 
Mr. Rogers thought it likely that they might pass the blowing process undamaged. This view of the creature's introduction was questioned, however, by Mr. Anthony, an eminent American conchologist, who was of opinion that the species did not inhabit the cotton-growing states. But Mr. Rogers further suggested that the shells might have attached themselves to submerged cotton used for defensive purposes-as barricades for steam-boats or river defences-during the war between the North and South, and that it might have been transported to this country during the cotton famine brought about by the war, when Lancashire people, it is said, were glad to get material in any condition, wet or dry, blockade-run, or otherwise; and this theory seems to have been generally accepted by British conchologists. The animal seems to have multiplied considerably in its new home: a few years after its discovery, when one of the canals was run dry for repairs, Mr. Rogers saw it, in countless numbers, extending about a mile from where it originally occurred; unfortunately, however, nearly all these vast numbers were killed when the brickwork of the waterway was repointed with mortar containing a good quantity of lime. In the Conchological Society's list the name of the species was enclosed in brackets, in order to denote that its claim to rank as British was not considered to be thoroughly established; but Mr. Collier, of Manchester, commenting on this in I 884 , expressed the opinion that the creature might be regarded as fully naturalized, and the brackets have been removed, I find, in a new edition 
of the list published in I 892.' Mr. Collier stated that he had not tried for some years to get the creature at Pendlcton, for when last there the towing-path side of the canal had been undergoing repair, a large quantity of new stones having been put down at the place where the shells used to occur, and the water "had become much worse"; at Gorton, however, he had found it repeatedly-some in $\mathrm{I}_{883}$-but not in great quantity, and not in the original habitat near the cotton-mill, but about a quarter of a mile away where the water was quite cold. In I886, seventeen years after its discovery at Manchester, the creature was found at Burnlcy, in the same county, in the "paper-works lodge" which has no connection whatever with any cotton-blowing machincry, the nearest cotton-mill being half a mile distant. In the following year, it was taken, also, in another Burnlcy locality, this time under conditions similar to those at Manchester, Mr. F. C. Long being reported to have found it, in thousands, in the canal opposite Temple's factory, where cotton refuse is blown into the water. It occurred along the canal for over a mile in the direction of Hapton, but was most plentiful opposite the mill. Mr. Rogers thinks it improbable that this colony was derived from Manchester, and inclines to the belicf that it was founded by shells or ova imported from Amcrica, in the same manner, and at about the same time, as those introduced into the Manchester canals, and he thinks it probable, 
also, that the two colonies near that city were distinct and separate introductions. The presence of the creature, in thousands, in a cistern on the top of an enginehouse at Burnley, "about sixty feet above the canal," has already been referred to. The shells had been pumped from the canal, no doubt, with the water supplying the cistern. As suggested by Mr. J. R. Wildman, the creature was probably carried by birds to the "paper-works lodge."

These are the only places in Britain, as far as I am aware, in which $P$. dilatatus has been detected. It is now nearly a quarter of a century since the first specimens were found, and it is surprising that the creature has not, by this time, extended its range beyond the limits of Lancashire, the county to which it was imported; within that county, as we have seen, it has been found in four separate localities. ${ }^{1}$

Physa ACUTA Drap. In the spring of 1860 , specimens of this pond-snail were found by Mr. A. Choules in a water-tank in the Royal Gardens at Kew, whither they are supposed to have been imported from abroad with aquatic plants. ${ }^{2}$ The shells, it is said, were un-

1 J. G. Jeffreys, "Ann. and Mag. Nat. Hist.," (4), iv., (I 869), pp. $34 \mathrm{I}-2$; T. Rogers, "Science Gossip" for I870, p. I38; "Quart. Journ. Conch.," i. (I875), p. 8I ; "Conchologists' Exchange," i. (I887), p. 63; “Journ. of Conch.," v. (I887), pp. 218-220; R. Rimmer, "Land and Fresh-water Shells," I880, pp. 47-9; E. Collier, "Journ. of Conch.," iv. (I884), p. 2 I 7 ; J. Bates, " Journ. of Conch.," v. (I887), p. 22 I ; J. R. Wildman, "Science Gossip," xxiv. (I888), p. 2 Io ; F. C. Long, "Science Gossip," xxiv. (I888), p. 28 I.

${ }^{2}$ It is doubtful whether $P$. acuta was previously known in 
distinguishable from specimens, in the British Museum, collected in Cuba, St. Thomas, and St. Croix. The Rev. A. H. Cooke, in I882, mentioned having taken the animal abundantly in the Victoria regia tank in the Royal Gardens, and I hear from Mr. J. B. Davy that Mr. Watson, the assistant curator, has seen it in "the lily-house, formerly called the Victoria regia housc." Probably the creature is not confined to any particular water within the gardens. The tank in which it was originally found is said to have been exposed in the open air to the inclemency of our winters, and this is not the case either with the lily or Victoria regic tanks, both of which are in warm houses. Mr. Cockcrell, in I 885 , reported that the species was "still abundant in a water-lily tank at Kcw." In I890, specimens were obtained by Mr. Grocock and Mr. Jenkins from the Royal Botanic Socicty's gardens, Regent's Park. They

Britain. According to Canon Norman the description in the Linnean Transactions of the "Bulla rivalis" of Naton and Rackett, I804,-said to have been found by Mr. James Hay in Hampshire-sufficiently accords with $P$. acutc (to which shell indeed Moquin-Tandon had assigned it as a synonym), and he remarks that Montagu, who was well aware that Bulla rivulis was a common West Indian shell, did not question the discovery of Mr. Hay. "Phy'se ccuta" is given also in Captain Brown's "Illustrations," 1844, as having been "found in Anglesea, Wales, and first identified as British by J. Sowerby, Esc..," but it is now stated that the shells, in this case, ought to have been referred to a variety of our common British species Physa fontinalis. See Maton and Rackett, "Trans. Lin. Soc.," viii. (1807). p. 126; T. lirown. "Illustrations," ed. 2, (1844), p. 30 ; Forbes and Hanley. "British Miollusca," iv. (1853), pp. I45-6; A. M. Noman, "Amn, and Mag. Nat. Hist.," (3), vii. (1861), pp. 115-16. 
occurred, in houses, in a tank containing seedlings of Victoria regia, and in glass vessels and tanks in which Vallisneric spiralis and other aquatic plants were growing. Very possibly they were introduced from Kew, for Mr. W. Sowerby tells me that the Royal Botanic Socicty is constantly cxchanging plants of all kinds with the Royal Gardens. The creature has occurred, also, in one locality in Scotland, having been collected, in ISS7, from three or four ponds in the grounds of the Banner Mill Company at Aberdeen. These ponds, containing warm water discharged from the mill, are tenanted also by gold-fish, various aquatic plants, and the common wandering pond-snail (Limneer peregre). Mr. W. D. Rae, who first collected specimens in this locality, stated in $\mathrm{r} 89 \mathrm{r}$ that the foreman had seen the creatures in the ponds ever since he came to the mill thirteen or fourteen years previously; sixtytwo living specimens were collected and forwarded to Mr. Rae, in London, in I890. Presumably the animal was introduced either with aquatic plants or with the gold-fish. ${ }^{1}$

A specimen of Lithoglypluus naticoides Fér., a fresh-

${ }^{1}$ A. Choulcs, "Zoologist," xviii. (I 860), pp. 72, 78.9; A. MI. Norman, "Ann. and Mag. Nat. Hist.," (3), vii. (I86I), pp. I I4-5; "Zoologist," xix. (I86I), p. 7355 ; "Ann. and Mag. Nat. Hist.," (3), ix. (I 862), p. I86; J. G. Jeffrey's, "British Conchology," i. (I862), p. I00; А. H. Cooke, "Journ. of Conch.," iii. (1882), p. 383; 'T. D. A. Cockerell, "Zoologist," (3), ix. (1885), p. I4 ; A. J. Jenkins, "Journ. of Conch.," vi. (I890), pp. 270.I ; W. D. Rac, "Scicnce Gossip," xxvii. (1891). pp. 89-90. 
water shell which inhabits the Danube, was once found, according to Mr. Jeffreys, in the bottom of a fishingboat at Cullercoats, Northumberland. ${ }^{1}$

Of terrestrial species, the Conchological Socicty's list ( $\mathrm{ISS}_{3}$ ) contains the names of eighty-six species, of which but threc, Testacella mangei, Helix villosa, and Bulimus goodallii can be reasonably looked upon as introduced by human agency; and two of these names (Helix villosa and Bulimus goodallii) are included within brackets, showing that the creatures' claims to be regarded as British were not considered to be established, and Helix villoser is known to have been placed in the catalogue on the faith of a colony which is now extinct. That the terrestrial molluscan faunas of the world have been much more influenced by man's dispersal than fresh-water faunas cannot be doubted, but this hardly scems to have been the case in our own country. It may be remarked, however, that the indigenousness of at least six species (in addition to the three above mentioned) has been questioned by various authors, and other authors have probably doubted the right of still other specics to rank as native. The evidence which can be got together does not, as far as I am acquainted with it, warrant the conclusion that any of these have certainly becn imported, but it is of coursc possible that this may have been the case with some of them. Of the three species generally regarded as introduced,

'Jeffreys, "British Conchology," i. ( IS6z), p. 70. 
Hclix villosa having died out need not be dealt with at present, but it will be well to recall the facts connected with the others, $T$. mangei and $B$. goodallii; and I have also added a note on Helix terrestris and Pupa cinerea, names which have appeared (in brackets) in the Conchological Society's new list of I 892.

Testacella maugei Fér-—a "snail-slug"-which scems to be a native of the south-west of Europe, and occurs also in Madeira, the Canary Isles, etc., was first noticed in England between the years ISI2 and I8I6, in Messrs. Miller and Sweet's nursery (now Garraway's), near Bristol, by Mr. T. Drummond; and Mr. J. S. Miller, in a paper published in I822, expressed the opinion that it had been introduced with foreign plants; but he added that it propagated freely in the open ground, increasing much in rich soil, and could "no longer be considered as an alien." Mr. J. De C. Sowerby, as appears by a note in Loudon's Mrgazine in I 83 , also regarded the animal as introduced, the original specimens having been imported, he thought, probably by accident, along with plants from Teneriffe or elsewhere; Mr. Alder, in 1838, while regarding $T$. haliotidea as a native, also thought the case different with the present species "which belongs to a warm climate, and has evidently been introduced along with exotic plants;" Gray (I 840 and I857), Forbes and Hanley (I853), Jeffreys (I862), Reeve (I863), Tate (IS66), and other authors agree in this view, and I am not aware that any writer has maintained that the 
creature is a native.' Jeffreys (IS62) remarked that it was still to be found in considerable numbers in the original habitat, and that it had becn observed also in other parts of Somersetshire, as well as at Plymouth, Cork, and in his own garden at Norton, near Swansca, which was occasionally supplicd with plants from Miller and Sweet's nursery. The occurrence of the animal in fields near Devizes is noted in Woodward's "Manual," but I find a statement, in I 867 , that it is found in that neighbourhood only when gerdeners are preparing their ground or digging up their crops. The Conchological Society's referecs have seen specimens from West Cornwall, North Somerset, Dorsetshire, Berkshire, West Gloucestershire, Glamorganshire, Pembrokeshirc, Waterford County, and the Channel Isles, and without doubt the creature has obtained a permanent footing."

BUlimus GOODALLII Miller.-This snail, which has now a wide range, is said to be a native of the West Indies,

'Since writing I find, however, that Dr. Scharff, in a recent paper on the distribution of the British land and fresh-water mollusca, seems to have regarded this animal as indigenous to our soil, and it is of course quite possible that such is the case. Sce "Conchologist," ii. (I892), pp. I-б.

"J. S. Miller, "Ann. Phil.," (n. s.), iii. (I822), p. 380 ; J. Fleming, "British Animals," I 828, p. 257 ; J. De C. Sowerby, as cited by J. D[enson], Loudon's "Mag. Nat. Hist.," vi. (I833), p. 45 ; J. Alder, "Mag. Zool, and Bot.," ii. (I838), p. 105; Gray's "Turton," I840, p. 5 ; 1857 , p. 292 ; "Forbes and Hanley," iv. (1853), p. 28 ; Jeffrey's, " British Conchology," i. (1862), pp. I47-8 ; Reeve, "Land and Fresh-water Mollusks," I863, p. 32 ; Tate, "Land and Fresh-water Mollusks," I860, p. 89; Woodward's "Nanual," ed. 2, (I 866), pp. 298-9; J. J. Fox, "Science Gossip" for 1 867, p. 89. 
and is belicved to have been introduced into England with pine-plants. It has been found in several widely separated places in this country, but can hardly be said to be acclimatized, for I believe it lives chicfly or exclusively in greenhouses, stoves, pits, etc. ; Dr. Turton, however, in I826, considered it "to be naturalized as much as the Testacellus mangei." Like that species it was first detected in Miller and Sweet's nursery, near Bristol, at about the same time or a little later, i.e. during the years I8I6-I7. The species was originally described from the British specimens, as Hclix goodallii, in a list of shells occurring in the environs of Bristol published by Mr. Miller in I822. The author mentioned that he found the creature, in ISI7, on boards lining a pine-bed. Mr. Drummond, in a letter to Dr. Fleming, however, stated that the animal was first pointed out by him in 1816 , and it appears to have occurred in some plenty, for, when a supply was required, he merely placed a flat board upon the surface of the tan, with a few dead worms beneath it, and this, in a few days, became "covered" with shells. Mr. Jeffreys (I 862) stated that the creature was still very common on the tan in the pineries in which it was discovered; he certainly erred, however, in saying that it had not been noticed elsewhere in this country, for Mr. Alder (1838) had mentioned having seen specimens from a garden in the neighbourhood of Manchester, and in Gray's "Turton" of I 840 the animal was said to be common in some places in the neighbourhood of London, especially in Kensington Palace Garden. Mr. 
W. Borrer tells me that he received specimens many years ago from the Royal Gardens at Kew. I hear from Mr. G. F. Wilson that a colony-first noticed, he thinks, nearly thirty years ago-used to cxist in a cucumber-house in a garden at Wandsworth, from whence specimens were submitted to the Scientific Committec of the Royal Horticultural Society and identified by Mr. Berkeley; possibly the creature was introduced with pines, for there was formerly a pinehouse in the garden. Weybridge has more than once been quoted as a locality for this snail, which has been erroneously stated-in the "Garden" newspaper for instance-to have occurred in Mr. Wilson's garden there; the mistake arose, no doubt, from the fact that while living at Wandsworth, Mr. Wilson had a garden at Weybridge, well known in the horticultural world. The snail seems to have occurred, in I876, in large numbers, in a cucumber-house at Gunnersbury. In ISSI, Mr. Ashford stated that it had flourished for many years in the orchid-houses of Mr. Day of Tottenham, from which locality he had procured living specimens in I 867 . Mr. F. W. Wotton mentions having received it, in 1886, from Mr. Chapman's greenhouse, presumably at or near Cardiff; and in one of the hot-houses in a garden at Croydon it was recently found in such vast numbers that all the soil in the house had to be collected and burned. Possibly the animal is now very generally distributed, in greenhouses, ctc., throughout a great part of the country.

"Turton, "Zoological Journal," ii. (IS26), p. 565; J. S. Miller, 
Helix terrestris Penn.-In the new list of I S92, as just mentioned, the name of an additional Helix has appeared, the present species, the Helix clegans of Gmelin, finding a place in the catalogue; its claim to rank as British, however, is not considered to be thoroughly established. The animal is common on the shores of the Mediterranean, especially in the south of France and Corsica, and is quoted also, according to Mr. Edgar Smith, from various localities in Spain, the Balearic Islands, Algeria, Italy, and Sicily, but it does not appear to range northward. It has recently been found, however, in the county of Kent, where what appears to be a thriving and well-established colony was discovered, in I890, by Mrs. McDakin, in the neighbourhood of Dover. The colony extends for about half a mile on a chalky bank, by the side of a road, in a retired locality some miles from the town, and far from houses or gardens. When discovered the animals were on the tall grasses in some numbers; and afterwards, when winter had set in, Mr. C. S. B. Cox was able to procure many living specimens, with their mouths closed with an epiphragm, lying almost

"Ann. Phil.," (n. s.), iii. (I822), p.3S I; J. Fleming, "British Animals," I 828, p. 266 ; Jeffreys, i. (I862), pp. 239-40; J. Alder, "Mag. Zool. and Bot.," ii. (I838), p. I Io ; Gray's "Turton," I840, p. 6 ; J. E. Daniel, "Garden," x. (1876), p. 542, and editorial note; "Quart. Journ. Conch." i. (I874-8), p. 246; and see also "Garden," x. (1876), p. 525 ; C. Ashford, "Journ. of Conch.," iii. (I881), p. 240, and "Science Gossip" for I868, p. I7; F. W. Wotton," Trans. Cardiff Nat. Soc.," xx. (I888), p. 36; K. McKean, "B. goodallii at Croydon," "Journ. of Conch.," vi. (I889), p. 84. 
invariably among lumps of frozen chalk, and sometimes frozen to the ground; many dead shells, of all ages, and in every condition of preservation, were also found. The position of the colony, in Mr. Cox's opinion, is suggestive of its having been intentionally introduced by a naturalist's hand, probably some few years ago. Mr. Smith agrees that the species is doubtless an importation, and thinks it probable that specimens recorded as having been found at Beauvais, in the north of France, were also introduced from a more southern locality. Mr. Carrington, writing in the Field, also agrees, remarking that there can be little doubt but that our colony was introduced, "cither purposely or by accident." A specimen of this shell was in Dr. Turton's collection of British shclls marked "Cornwall ;" the birth-place, Mr. Jeffreys remarks, of many spurious or cxotic shells. The Trochus terrestris of Pcnnant is said to have bcen discovered in the mountains of Cumberland, but it is perhaps doubtful whether that author really intended to indicate the present species, and I have used his name merely because the compilers of the Conchological Socicty's list have done so. It is curious to find that a colony of $H$. terrestris was discovered, in I875, in a churchyard in Charleston, South Carolina.'

'C. S. B. Cox and E. A. Smith, "Journ. of Conch.," vi. (I89I), pp. 377-9; J. T. Carrington, "Field," 29 August, IS9I, p. 334; "Jeffreys," i. (1862), pp. 215-16; Pennant, "British Zoology," iv. (1777), p. III ; and see Gray's "Turton," I840, p. 9 ; Mazyck, "Proc. Acad. Nat. Sci. Phila.," I S76, p. I27, quoted by Mr. Smith as above. 
Pupa Cinerea Drap. is also included, as doubtfully British, in the new catalogue, "in the faint hope that its claim to inclusion in the British list may be strengthened by further observation." Jeffrcys, in I $83 \mathrm{I}$, stated that a specimen had been found by Mr. Gray among the rejectamenta of the Thames at Battersca, and he himself had detected an imperfect specimen at the same place. But, in I 840 , Gray treated the species as having been improperly regarded as British, stating that he had introduced it into the fauna in error, a specimen having been accidentally mixed by Dr. Leach with some other shells collected at Battersea, and Mr. Jeffreys' record, also, he thought, was probably erroneous. More recently, however, specimens all presumably dead-two of which have been identified by Mr. J. W. Taylor-are reported to have been taken, on four occasions during twelve years, near Accrington, Lancashire. Their presence may most probably be attributed to man's dispersal, but some naturalists think it unlikely that they were thus introduced, for the locality is described as "well-wooded out-of-the-way."

As already stated, there are at least six other landshells in the British list which have been regarded by authors as probable or possible importations. Very likely all of them are indigenous, but, be this as it may,

1 "Journ. of Conch.," vii. (I892), pp. 54-62; J. G. Jeffreys, "Trans. Lin. Soc.," xvi. (1833), p. 5I4; Gray's "Turton," (1840), p. I3 ; R. Wrigglesworth, "Science Gossip," xxv. (I889), p.28I ; and see also "Naturalist," I 892, p. 336. 
it is certain that the contrary cannot now be positively asserted; we are unable to distinguish our native fauna with any degrec of certainty. ${ }^{1}$ A few notes on the species in question, beginning with the famous and much discussed edible or Roman snail may be given.

Helix pomatia L. Merret and Lister, two very carly writers on the British fauna, do not seem to have doubted the indigenousness of the edible snail to this country; the first-named author in his "Pinax," published in 1667 , mentioned the animal (according to Gray) without any note, as found in Sussex; and Lister in his "Historiæ Animalium Angliæ," dated in 1678, mentioned it, as "Cochlea cinerea, maxima, edulis, etc.," as one of the largest of the land-shells of our island, and, as far as I am aware, he never suggested that it might have been imported; it was plentiful, he said, in Hertford and other places in the south of England, but he had never found it in the north. Ninety-nine years later, strangely cnough, we find Pennant (in I777) naming the species "exotic," and stating that it had become naturalized in the southern counties, having been introduced, it was believed, by the eccentric Sir Kenelm Digby, either for medical purposes or as a food; "tradition says that to cure his beloved wife of a decay was the object." In I778, Emanuel Mendes da Costa named the creature "Italian," and gave a curious and interesting disscrtation as to its introduction and subsequent dispersal :

'See Rimmer's "Land and Fresh-water Shells," (1880), p. 145. 
"This snail is not indigenous, or originally a nertive of these kingdoms, but a natmolised species, that has throve so well as now to be found in very great quantities. It was first imported to us from Italy about the middle of last century, by a scrvoir wire, or Epicure, as an an [sic] article of food. Mr. Anbrey informs us, it was a Charles Howard, Esq., of the Arundel family, who, on that account, scattered and dispersed those snails all over the downs, and in the woods, ctc., at Albury, an antient seat of that noble family, near. Ashted, Boxthill, Darking, and Ebbisham or Epsom, in Sury, where they have thriven so much that all that part of the county, even to the confines of Sussex, abounds with them; insomuch that they are a nusance, and far surpass in numbers the common, or any other species of English snails.

"The Epicures, or scrvoir vivre, of those days, followed this luxurious folly, and the snails were scattered or dispersed throughout the kingdorn, but not with cqual success; neither have records transmitted to postcrity the fame of those worthies equal to the Roman Fulvins Hirpinus, exccpt of two, the one Sir Kenelm Digby, who dispersed them about Gotmest, the seat of that family (now of the Wrights) near Neruport Prgnel, in Buclinghamshire, where probably they did not thrive much, as they are not very frequent thereabout: the other worthy was a Lord Hatton, recorded by Mr. Morton, who scattered them in the coppices at his scat at Kirby, in Northamptonshire, where they did not succeed.

"Dr. Lister found them about Puckeridge and Wrre, in Hertfordshire; and observes they are abundant in the 
southern parts, but are not found in the northorn parts of this island.

"In Surrey, as before mentioned, they abound; in several other counties they are not uncommon, as in Oxfordshire, especially about Woodstock and Bladen; in Gloncestershire, in Chedworth parish, and about Frog Mill; in Dorsetshire, etc., but I have never heard that they are yet met with in any of the northern connties."

Pulteney, in his Dorsetshire catalogue of I799, gave the species along with the other Helices, and made no statement as to whether he considered it indigenous or introduced, but, after stating that it had been recorded for Dorsetshire, added, "happily this kind does not thrive well in England." He neither followed Pennant in naming the creature "exotic" nor Da Costa in calling it "Italian," giving instead the more appropriate English name of "Edible snail;" but Donovan, following in ISOI, again called the animal "Italian or exotic," and agreed with Pennant and Da Costa in regarding it as an importation. By whom it was first introduced, he remarked, was uncertain. In I 803 , Montagu, in his "Testacea Britannica"-_"next to Müller one of the best works on land and fresh-ivater shells "-wrote in a similar strain, remarking that the creature was "first introduced about the middle of the sixteenth century either as an article of food or for medical purposes," and repeating the stories told by Pennant and Da Costa respecting the reputed doings of Sir K. Digby and Mr. Howard. Dr. Maton and the Rev. Mr. Rackett, in their catalogue read at the Linnean Society in ISO4, 
also mentioned the creature's supposed importation by Mr. Howard; and they referred to its presence in the additional countics of Wiltshire and Kent. In ISI7, Dillwyn gave England as one of the habitats of this snail, but without any statement as to its introduction; and Turton, in his "Conchological Dictionary of the British Islands," in ISI9, gave the "edible snail-shcll," along with the other species of the genus, presumably as a native, making no statement as to whether it was to be regarded as indigenous or imported; but, even in I 830 , we find the statements both as to Sir K. Digby and Mr. Howard again repeated, this time by Dr. George Johnston, and they have been further repeated no doubt by other writers. Fleming, in $\mathrm{I} S 2 S$, was probably inclined to consider the animal as an indigene, but he made no direct statement to this effect, simply observing that some had conjectured that the species was introduced into England by Mr. Howard about the middle of the sixtecnth century; it is noteworthy, however, that he did not give it as a "naturalized species," like B. goodallii, nor as a "straggler" like D. polymorpha. Turton seems to have been the first to publish an express opinion that $H$. pomatic was in all probability a native species, which he did, in his "Manual," in $183 \mathrm{I}$, remarking that at one period the animals appeared to have been admitted at our own tables, "as Lister in his 'Historiæ Animalium Anglix,' p. II I, tells us the manner in which they wcre cooked in his time," and Ben Jonson, in "Every man in his Humour," mentions the dish as a delicacy-" neither have I dressed 
snails or mushrooms curiously before me,"-and these circumstances, he added, "suppose their long foreknown establishment in this country, and together with their general diffusion in certain soils, incline us to consider them as indigenous, and not introduced by Sir Kenelm Digby for medical purposes, nor, according to Da Costa, by Mr. Howard as an article of food." This conclusion is probably a just one, but it may be observed that Lister's remarks do not at all imply that the creature was admitted to English tables in early times; Da Costa understood Lister to say that the animals were cooked, in the manner indicated by him, in continental Europe, and no doubt rightly, for the often quoted remark, "Coquuntur ex aqua fluviatili, et adjectis olco, sale ct pipere, lautum ferculum præparant," although a scparate paragraph, follows immediatcly upon the statement, "In Gällia Narbonensi admodum vulgò eduntur. Item Parisiis tempore quadragesimali magnâ quantitate væncunt."

Turton's vicw received support, in I839, from Forbes, who, in his "Report on the distribution of Pulmoniferous Mollusca in the British Isles," expressed the opinion that there were good grounds for regarding the creature as indigenous: "when we consider the partiality" shown by that shell for the newer calcareous strata in all parts of Europe, and the geological correspondence of its British and continental habitats, I think there can be but little question of its indigenousness;" Gray, in both his editions of "Turton" (I 840 and I 857 ), followed the view originally expressed by the author in the first 
edition, and Captain Brown (I 844) also regarded the animal as a native, as did Forbes and Hanley in their "British Mollusca" (IS53); and indeed, I am not aware that any post-Turtonian author, with the exception perhaps of Reeve,' has reverted to the older belief of Pennant, Da Costa, and their followers. Leach, it seems, held the view that this snail (Ponatia antiquomm he called it) was an indigenous species long before the publication of Turton's "Manual," for he referred to it as such in his "Synopsis," published by Gray in 1852 , which is said to have been in course of printing when the author was prevented from completing it by ill health in I S2O, and to have been re-printed and issued exactly as it was left; the creature's general diffusion in a certain soil, he remarked, seemed to refute the notion, held by many, that it had been imported from the continent for the use of invalids. Mr. Jeffreys (I862) was of opinion that there was no reason to suppose that the creature was imported from Italy in the sixteenth century, and he regarded it as equally indigenous, probably, with $E_{1}^{T}$. aspersa, our common gardensnail. Neither of these species, he added, had been found in this country in any recognized stratum of the upper tertiary formation. Further, there was no foundation, he thought, for the idea, prevalent at one time, that $H$. pomatio had been introduced by the Romans, for though found near several encampments, it had occurred neither

"Since writing I find that Mr. Musson has recently referred to $H$. pomatia as having been "taken to Britain by the Romans." See "Proc. Lin. Soc. N.S.W.," for $1890,(2)$, v. (1891), pp. 8\$3-4. 
at Wroxeter nor at York, nor in many other parts of England and IVales where the Romans built cities or had important military stations, and in "all probability this kind of snail was not known to them, as another species (H. lucomm) takes its place in Central Italy." Recurring to the subject in Nature, in I $88_{3}, \mathrm{Mr}$. Jeffreys added that among the débris of an extensive Roman villa, discovered in Northamptonshire, in which the shells of cockles, oysters, mussels and whelks abounded, not one of $H$. pomatic occurred, although at Woodford, a few miles distant, it is plentiful in a living state. The Rev. L. Blomefield, writing from Bath in the same journal, stated that he had neither found, nor heard of the discovery of, a single specimen, either living or dead, in the neighbourhood of that city, which the Romans occupied for more than four hundred years. On the other hand, Mr. D. Pidgeon, though believing the supposed connection between Roman remains and $H$. pomatic to be merely fanciful, has remarked that a fine example of the Roman villa stands at a short distance from the spot near Charlbury, Oxfordshire, where, within somewhat narrow limits, the snail is now abundant.

It is curious to find that Reeve (I S63) differed from his contemporaries, and stated that the present species could hardly be said to be indigenous; he remarlied, however, that if not indigenous it had become fully naturalized in our southern counties. Tate (IS66) did not express any opinion on the point, and Rimmer ( ISSO) merely quoted Jeffreys. 
I have no means of indicating the cxact range of $H$. pomatia in this country; it seems to be confined for the most part to chalky soils. Jeffreys mentions its occurrence in woods, hedge-banks, and uncultivated places in Surrey, Hertford, Kent, Oxfordshire, Wiltshire, and Gloucestershire; the Leeds Consus records it for the additional counties of IIampshire, Susscx, and Bedfordshire, and the creature, as we have seen, is said to have becn found in several other countics.

It secms uscless, at this time, to offer a decided opinion as to whether the animal is really indigenous to our soil or not: the doctors have differed, and there appears to be no actual cvidence on either side; the weight of opinion, however, as far as conchological authors are concerned, has for a long time favoured the creature's indigenousness, and the absence of any suggestion that it was foreign to our fauna in the works, now more than two hundred years old, of Merret and Lister certainly scems to support this vicw, which was held, we have secn, by Leach, Turton, Gray, Forbes, Jeffreys, ctc. On the other hand, we have also scen that Pennant and Da Costa, who wrote more than a century ago, both stated positively that the creature was a naturalized species, and they were followed in this view by more than one writer, and even by the illustrious Montagu. When a species originally introduced by man cstablishes itself in a ncw country, subscquent naturalists, in the absence of records, will always be likely to mistake it for an aboriginal inhabitant of that region, cspecially if the creature has happened to stray 
beyond the confines of cultivation. In the absence of information on the point, for instance, a person visiting Cape Town would hardly regard $H$. aspersa, which he might find in the ncighbourhood in large numbers, as a comparatively recent importation from Europe. Supposing $H$. pomatic to be really indigenous in England, it secms somewhat difficult to account for the wide-spread notion that such is not the casc. The belief that the creature was imported from abroad by our own countrymen, we have seen, has prevailed for a long time, and is perhaps more general than the idea that it was introduced, previously, by the Romans. In I 863, we find Reeve stating, on the authority of a Mr. Barlow, that "specimens had been transported from Italy some thirty years before by an English noblcman," to the range of hills in the neighbourhood of Reigate and Box Hill, in Surrey, "and as they had bred abundantly Mr. Barlow was induced to take a house in that locality," in order that a dict of snails might bc administered to one of his sons, who was considered to be in the last stage of consumption. A correspondent writing to Nature, in I883, mentioned that when collecting the shells of this animal, many ycars ago, about the foot of Box Hill, he was told by a farmer resident in that neighbourhood that "the snails were brought from Italy by Mr. Hope, of Deepdene, who was well known in the carly part of this century as a writer on the mediæval architecture of Italy." Murray's "Handbook to Surrey" and Bevan's "Guide" both refer to the creature as imported, the first-named stating that it 
is supposed to have been introduced near Guildford by an Earl of Arundel. The correspondent to Nature, before quoted, who lived from I $\$ 49$ to I $\$ 52$ within two miles of Voodford, Northamptonshire, where this species occurs in a small wood known as Woodford Shrubbery, stated that it was commonly said in that neighbourhood that the snails were originally brought from abroad by General Arbuthnot (?) who had formed the Shrubbery some thirty years before. It seems likely that there is some foundation for such statements as these, or some of them, and it can hardly be doubted but that the animal, although possibly or probably truly indigenous, has been imported from abroad from time to time. ${ }^{\mathrm{I}}$

"Merret, "Pinax," 1667, as quoted in Gray's "Turton," I 840, pp. 35, 46 ; Lister, "Historiæ Animalium Angliæ," I678, pp. I I I-12, as translated for me by Mr. R. W. Goulding; Pennant "British Zoology," iv. (I777), p. II7; Da Costa, "Historia Naturalis Testaceorum Britannix," I778, pp. 67, 70-I ; Pulteney, "Dorsetshire Catalogue," 1799, p. 47; Donovan, "Natural History of British Shells," iii. (I80I), plate lxxxiv. (pages not numbered); Montagu, "Testacea Britannica," ii. (I803), p. 406; Maton and Rackctt, "Trans. Lin. Soc.", viii. (I807), p. 202; Dillwyn, "Descriptive Catalogue of recent Shells," ii. (I8I7), pp. 920-I ; Turton, "Conchological Dictionary," I819, p. 56 ; Fleming, "British Animals," I 828, p. 257 ; G. J[ohnston], Loudon's "Mag. Nat. Hist.," iii. (1830), p. 47 ; Turton, "Manual," I 831, pp. 47-8; Edward Forbes, "Report 9th meeting, British Association, I839"" (1840), pp. I30, I33; Thomas Brown, "Illustrations," ed. 2, (I844), p. 43; Gray's "Turton," I 840. pp. 35, I 37 ; I 857, pp. II 3-14 ; Leach, "Synopsis," I852, pp. 64-5; "Forbes and Hanley," iv. (1853), p. 48; "Jeffrcys," i. (I862), pp. I77-8; "Nature," xxvii. (I883), p. 5 II; L. Blomefield, "Nature," xxvii. (I883), p. 553; D. Pidgeon, "Quart. Journ. Conch.," i. (1875), pp. 54-6; "Rceve," I 863, pp. 60-2 ; "Tate," 
Helix Cantiana Mont. The Kentish snail, Mr. Gray remarked, in 1857 , was once "supposed to be almost confined to the four metropolitan counties, but it is also found in Suffolk, near Bristol, and near Dublin. It may have been introduced in these latter localities; for it has been within these few years, according to Mr. Fryer, introduced with ballast by the colliers on the banks of the Tyne, and is now rapidly spreading itself in the hedges of that neighbourhood. These circumstances would lead one to imagine that it might also have becn introduced into England from the Continent; but Férussac, who has compared it with the continental species, regards it at least as a local variety of $H$. carthusianc of Draparnaud (not of Müller), which is a native of the south of France and Italy." Professor Tate, however, has stated that the creature is indigenous, at least to certain parts of this country; most writers, indeed, have thus regarded it, and now that it is known to have a much more extended range than that above indicated (except that the Dublin record is perhaps erroneous) it can hardly be looked upon even as a possible importation.'

I S66, p. 137 ; "Rimmer," ISSo, p. 113 ; J.C., "Nature," xxviii. (IS83), p. 31 ; W. C. Atkinson, p. $S_{I}$; Nurray's "Handbook to Surrey," p. 70 ; and Bevan's "Guide to Surrey," p. I I I., as quoted by Mr. Atkinson.

"Gray"s "Turton," I S57, p. I 30; "Tate," I S66, pp. I26-7; and see also, as to the probable dispersal of $H$. cantiance with ballast, E. Forbes, "Report, 9th meeting. British Association, i 839," (I 840), p. I 31 ; B. Hudson, "Journ. of Conch." iv. (1884), p. I7 r ; and J. E. Kobson, quoted in the "Naturalist," I8S6, p. I 48. 
Helix Cartusiana Müll. This snail (which, according to Mr. Jeffreys, is known to inhabit the whole of France, the Rhine district, South Germany, Switzerland, Dalmatia, Italy, and Greece, and has been recorded as a Siberian species) was detected in Britain in ISI4. In this country, however, though plentiful where it occurs, it has a very restricted range, being confined, apparently, to the neighbourhood of the sea, along the coasts of Kent and Sussex; and Jeffreys, it appears, at one time thought that it had been naturalized here by an importation from the opposite coast of France; but at the time of the publication of the "British Conchology" he regarded it as "clearly indigenous." A colony, known at one time on the east moors near Cardiff on a small patch of raised ground covered with a luxuriant growth of ballast plants, was almost certainly introduced with ballast; but the creature has now disappeared from that locality."

HELix PISANA Müll. Extremely local as a British species, this snail is distributed at random in a few widely separated places on or near the coast; in the Channel Isles, it occurs in Jersey, in the south of England in Cornwall, in Wales in Pembrokeshire, and in Ireland in Meath and Dublin counties; intentionally introduced colonies are known to exist near Swansea, in Guernsey, and possibly in other places. The creature's foreign distribution, Mr. Rimmer has

1 Jeffreys, "Trans. Lin. Soc.," xvi. (1833), p. 509; "British Conchology," i. (1862), pp. 48-9, 193-4.

2F. W. Wotton, "Journ. of Conch.," v. (I886), 
observed, is by no means confined to the sea-board, and in his opinion the fact of its range in this country being limited to a fow places on the coast is suggestive of the idea that it may have been originally "brought over in ballast from the Continent, or perhaps from Jersey."

Helix obvoluta Müll. This species (the chesse snail of Gray's "Turton"), unknown as an inhabitant of this country to the early writers on our conchology, was first recorded as British in March, IS3I, by Dr. James Lindsay, who discovered it, in I 830 , "apparently indigenous," amongst moss near the roots of trees in Ditcham Wood, near Buriton, Hampshire, and it was to be found, he added, for a considerable distance along the chalk escarpment of the South Downs facing to the north. He had collected more than twenty specimens. The creature inhabits central Europe, and occurs, also, according to the "British Conchology," in the north of France; its indigenousness in Britain was doubted by Mr. Jeffreys (I83I), who observed that "its confined locality and the circumstance of its having remained so long unnoticed by British authors might warrant a suspicion that it may be of the same recent and precarious indirenousness in this country with the $H$. carthusianclla" (or cartusiana) which he then regarded as a possible importation from France. ${ }^{3}$ Gray (IS40)

1 "Jeffreys," i. (1862). pp. 20S-9; "Rimmer," (1880), p. 133.

$"$ J. Lindsay, "Trans. Lin. Soc.," xvi. (1 833), p. 765.

3 J. G. Jeffreys, in the supplement to his "Synopsis" read in 1831 , "Trans. Lin. Soc.." xvi. (1833). p. 510. 
suggested that the creature might be an escape, introduced with foreign plants; Captain Brown (IS44), Forbes and Hanley (IS53), and Recve (IS63), also regarded it as imported or questionably indigenous. The Rev. W. H. Hawlier ( I S53), however, when recording the finding of many specimens in the beech-hangers covering Stoner Hill, Ashford, Hampshire, expressed a belicf that the specics was a native. It was impossible, he thought, that the animal could have spread or wandered over the low and flat country between the Ditcham and Ashford Woods, the two habitats being about six miles apart.' It may be remarked, of course, that there are various means by which the creature might have been transported from one place to the other; but it has since been found at points many miles distant from the original habitat, and Jeffreys has referred to it in the "British Conchology" (IS62)" as clearly indigenous. It sometimes occurs in this country in fair plenty, but its known range, it must be admitted, is still very limited, being confined, I believe, to a

1 W. H. Hawker, "Zoologist," xi. (1853), pp. 3764-5; and see also on the British habitats of $H$. obvoluta: J. E. Harting, "Zoologist," (2), ii. (I S67), p. 760; W. Thomson, "Zoologist," (2), ii. (1867), p. 837 ; C. Griffith, "Science Gossip," for 1873, p. 276; T. Godlee, "Quart. Journ. Conch.," i. (1874-8), p. 68; J. E. Harting, "Zoologist," (3), ii. (1878), p. 94; W. Jeffery, "Journ. of Conch.," ii. (I882), pp. 316, 339; B. 'Tomlin, "Science Gossip," xix. (1883), pp.67-8; C. Ashford, "Science Gossip," xix. (I883), p. 89; 'T. I). A. Cockerell, "Zoologist," (3), ix. (1885), p. 380 ; S. J. Ia Costa, on its occurrence (dead) in the woods of Norbury Park, Surrey, "Journ. of Conch.," v. (I886), p. 81.

2 pp. 4S-9. 
comparatively restricted area within the counties of Hampshire and Sussex, and to a single locality in Surrey; in Wales, Ireland, Scotland, and the north of England it appears to be unknown.

Mr. Clement Reid has recently worked out the British distribution of the creature, and at the Linnean Socicty in December, I $\$ 90$, he exhibited a map showing its range, together with specimens from "new localities in Sussex." In reply to an inquiry he has favoured me with the following note:

"The point of my remarks at the Linnean Society was this: I found that $H$. obvolute, instead of being confined to a small area on the borders of Hants. and Sussex, extended eastward along the chalk escarpment as far as suitable localitics were to be found. The species secms to be very particular as to its habitat; it must have calcareous soil and plenty of shade, but the ground must never be sodden. It seems also to be an exceptionally sedentary species, for as far as I could sce it was confined to ancient woods, and was never to be found in plantations, even if the trees were a hundred ycars old.

"Almost the only place where the necessary conditions are combined is the chalk escarpment, for there we find slopes too steep ever to have been cultivated, and on these, consequently, are preserved many patches of the ancient forest. Nearly all these scattered patches, as far east as the River Arun, are full of Helix obinluter. 
East of the Arun there are few traces of the old forest, and I have not yet come across this snail. In the extcnsive becch woods on the top of the Downs the species is nearly always absent, but most of these woods have been planted within the last hundred years, and the few relics of old forest are on ground liable to become sodden in the winter. Helix obvolute has been recorded from Kingley Vale, on the south slope of the Downs. I could not find it there mysclf; but it occurs in a copse about four miles to the north.

"Everything seems to show that the creature is a relic of our old woodland fauna, now nearly exterminated through the destruction of the forests."

Testacelia haliotidea Drap. Gray (is40) coupled this snail-slug with Dreissena polymorpha as a species supposed to have been introduced in modern times, but he regarded it as well naturalized, and possibly indigenous. Jeffreys (I 862) thought it almost impossible to say whether the creature was a native or had been introduced, but Mr. Rimmer has, more recently, expressed the opinion that there are "some grounds for believing it to be indigenous;" he remarks, however, that it has doubtless been unintentionally imported, from time to time, from abroad in soil at the roots of shrubs and other plants. Mr. Alder, as long ago as I838, thought it might be reasonably regarded as a native. Testacella scutulum Sby. which appears in the new British list as a distinct species, has been included, for a long time and until quite recently, under T. halio- 
tider as a variety: the aggregate has a fairly wide range in this country, and the creatures sometimes occur in large numbers, but it appears that T. haliotidea proper is less common than T. scutulum, for, according to the Leeds "Census" ( I889), the latter has been seen by the Conchological Society's referees from thirteen counties, and the former from only eight. ${ }^{1}$

The following molluscs, probably among many others, all exotic, have been detected in Britain, either in a living state or as dead-shells. Some have been found alive in open places, like true members of our fauna, and several have actually been admitted, at one time or another, into the British lists. Most of them have almost certainly been imported by man, no doubt for the most part unintentionally.

Helix Limbata Drap., the "white-keeled snail" of Gray's "Turton," a native of the south of France, etc., is said to have been found in the neighbourhood of London by Mr. G. B. Sowerby, and was introduced into our catalogues, in I $337-S$, by Mr. Alder, who had received specimens from Mr. Sowerby. Gray included it in his "Turton" of I $\$ 40$, stating, on Mr. Sowerby's authority, that it lived "in the hedges near London, on the New North Road to Barnet, near Hampstead, on

1 Gray's "Turton," I 840, p. 4; 1857, p. 291 ; "Jeffreys," i. (1862), p. 146; "Rimmer," I 880, pp. 88-9; Joshua Alder, "Mas. Zool. and Bot.", ii. (1838), p. 105 ; on the specific distinctness and sreographical distribution of $T$. scutulum, see J. IV. Taylor, "Journal of Conch.," v. (ISSS), pp. 337-47. 
brambles." He admitted, however, that the specimens originally found had possibly been accidentally introduced with some plant from the Continent, for after considerable inquiries he had not been able to hear of the finding of any other specimens, either in the same locality, or elsewhere. Forbes and Hanley (1853) gave the creature as a "spurious" British species, and Gray in the "Turton" of I 857 referred to it as a shell introduced into the fauna by mistake. The statement in this edition that "a few living specimens were set free on the New North Road, near Hampstead, by Mr. G. B. Sowerby; but they did not propagate themselves," is somewhat puzzling, and probably wrong. Mr. G. B. Sowerby, grandson of the finder or liberator, is inclined to think that the statement in the edition of 1840 is correct, but he has no note of the facts. Jeffreys, we find, noticing the species in I 862 , even thought that it might possibly be "rediscovered in this country and have its claim to admission as a British species recognized."

Helix LACTEA Müll. A living specimen of this fine Mediterranean snail was once found, by Mr. Kindon, in a field near the railway at Pateley Bridge, Yorkshire, and was forwarded, still alive, to Mr. Taylor of Leeds. It had probably been carried, as Mr. Taylor supposes, with shingle brought by rail from the coast, and the finding by Mr. J. H. Salter in the following year of a

"Alder, "Mag. Zool. Bot.," ii. (1 838), p. Io6 ; Gray's "Turton," I 840 , pp. 34, 53, I43-4; I857, pp. 293-4; "Forbes and Hanley," iv. (I853), p. 85 : "Jeffreys," i. (I862), p. 192. 
shell of the same species, "only recently dead," on the sands at Filey on the coast of the same county doubtless strengthens such a supposition. Both specimens were probably imported with ships' ballast. Another shell of the same species, presumably dead, has been found on the moors near Cardiff, on which ballast is often deposited. ${ }^{1}$

Helix Carthaginiensis Rossm. A specimen of this Spanish snail, found alive on the Cardiff moors by Mr. Wotton-probably introduced with ballast-was shown at a meeting of the Conchological Society in I 883 ; with it, a few dead-shells of the same species had also occurred. ${ }^{2}$

Helix villosa Drap., a native of central Europe, has also been found at or near Cardiff, Mrs. David Robertson, of Glasgow, having taken four living specimens, in August, I873, while searching for Ostracoda in the ditches on the moors. In 1877 , Jeffreys recorded the species, in the "Annals and Magazine," as "an addition to our mollusca," on the strength of which it appeared (marked as doubtfully British) in the Conchological Socicty's list of I883. It is now clear, however, that the animal has no claim whatever to be regarded as native to this country. It has not even

"J. WV. Taylor, "Journ. of Conch.,"v. (I SS6), p. 8I ; "Naturalist," I886, p. 25 I ; IV. E. Clarke and others, "Naturalist," I 886, p. 207 ; J. H. Salter, "Nat. Hist. Journ.," ix. (I88j), p. I 87 ; E. Collicr, "Journ. of Conch.," iv. (I884), pp. I 5 I, 2 I 4.

"Iroc. Conch. Soc., "Journ. of Conch.," iv. (I884), p. I5 I ; E. Collier, p. 214. 
established itself in the above locality. The four living specimens mentioned are the only ones (other than those intentionally introduced or their descendants) which have been detected in these islands, and the name of the species has very properly been omitted from the new list of $\mathrm{I} \$ 92$. Mr. Collier and Mr. Rogers, as stated in I $\$ S 4$, visited Cardiff soon after the finding of Mrs. Robertson's specimens, but, although they found the exact spot in which the creatures had becn picked up, they failed to discover other specimens, and came to the conclusion that those originally found were ballast shells, the moor being the "place where all the ballast is put." Mr. Wotton, in I886, mentioned that the original shells were found near a small patch of raised ground, covered with ballast-plants, where the $H$. cartusiana, no doubt accidentally introduced, was formerly known to occur. He had searched closely very many times for $H$. villosa, but without success; the creature had certainly been imported, he thought, probably with ballast, or possibly with Esparto grass, large quantities of which are brought into Cardiff and stored on the moors. A brickyard, he added, "now covers the spot where $H$. villos $\alpha$ was taken, and various works and docks are fast occupying the ground." About forty years ago, as already noticed, Canon Tristram turned loose, on a moor in co. Durham, several specimens which he had brought alive from Switzerland, and they or their posterity were ascertained to be living in the same place ten ycars afterwards. The Rev. J. W. Horsley, also, has 
recently liberated Swiss specimens in his garden at Woolwich. ${ }^{1}$

Helix vermiculata Müll. This snail, a fine and well-known Mediterranean species, has not (as far as I know) been found living in Britain as an escape; it has becn accidentally imported, however, in a living state, and this is more than can be positively said for the two following species, H. aperta and H.personata, both of which have actually been put forward by eminent conchologists as members of our fauna. In I89I, Mr. L. E. Adams sent for exhibition at the Conchological Socicty a specimen of $H$. vermiculata which he had reccived from Barnslcy as a Kentish shell. In investigating the history of the specimen, he ascertained that it arrived in Barnsley, in January, I89I, in a parcel of horchound, consigned to a chemist in that town. The horchound was said to have been grown in Kent, but was procured in the ordinary way of business from a tradesman in London who was known to deal largely in foreign herbs, and as the horehound in question may have been in his warehouse for several months, the probability is, as Mr. Adams thinks, that the snail crawled amongst it from some foreign herb which was also stored there. Mr. Adams tells me that the creature was alive when it arrived in Barnsley.

' J. G. Jeffreys, "Ann. and Mag. Nat. Hist.," (4), xix. (1877), pp. 199-200; E. Collier, "Journ. of Conch.," iv. (I 884), p. 2 I4 ; F. W. Wotton, "Journ. of Conch.," v. (1886), p. 56; H. B. Tristram, "Zoologist," (3), i. ( (877). pp. 260-I.

2 P'roc. Conch. Soc., "Journ. of Conch.," vi. (1891), p. 393. 
[Helix APERTA Born, another Mediterranean species, hardly ought to be mentioned here at all, for it has never been found, as far as I know, cither living or dead, in any of the islands of the British archipelago; it was introduced into our fauna, however, in I 839 , when a specimen received from Forbes, as from Guernsey, is said to have been placed in the British Museum by Gray; but Guernsey, of course, belongs geographically to France. The species was included by Gray in the "Turton" of I840, where it is stated that the shell, which was a crushed specimen, was found in mud under the side of a hedge, a situation similar to those in which Forbes had found the snail in Provence; and Forbes and Hanley included it in their celebrated work of I 853 ; but, in the "Turton" of I 857 , Gray excluded it, believing that it had been previously included by mistake. Jeffreys (IS62) remarked upon the fact that the sole ground for supposing the species to be a native was the discovery of the shell above mentioned (which he described as a dead specimen found in a cart-track), adding that Dr. Lukis, then and at the time of the discovery a resident in Guernsey, had frequently searched for the shell in vain; its shape, he significantly remarked, "is not much unlike that of the variety temuis of Helix aspersa which is common in Guernsey and is frequently bandless and without coloured markings." $\mathrm{He}$ also stated that Forbes' shell could not be found for reference in the British Museum, Dr. Baird (then in charge of the shells) never having seen it. Quite possibly, of course, as Jeffreys admitted, the shell in question 
was the true Helix aperta imported and dropped by some French sailor, or it may have been introduced with plants.] '

HELIX PERSONATA Lam. Jeffreys, who did good service in helping to banish $H$. aperta and other foreign shells from our catalogues, was himself guilty of the insertion of other species which are now known to have no claim whatever to be regarded as British. H. villosa, we have just seen, was introduced by him in 1877 , and previously, in the "Annals and Magazine" in 1870, he had introduced the central European $H$. personata:-

"The tale of British land and fresh-water shells is not yet told. A dead specimen of Helix personata has been found by Mr. S. A. Stewart, of Glasgow, at Newcastle, in co. Down; and it is now ... in my possession. Last year I examined Mr. Stewart's collection of fossil shells from the Post-Tertiary beds at Belfast and in that neighbourhood, and I have since received several communications from him on the same subject. Judging from his accuracy in these matters, I have every reason to believe that $H$.personata is a native of Ireland, and that his specimen was not accidentally introduced, as was the specimen of $H$. aperta into the Channel Isles."

In I 883 , when a discussion arose in "Science Gossip" as to the admission of certain land-shells into the British list, Mr. Stewart wrote to corroborate a statement that the claim of $H$. personata as a British species rested on

'Gray's "Turton," 1840, pp. 36, 53, 127-8; 1857, p. 293; "Forbes and Hanley," iv. (1853), pp. 43-4; Jeffreys, i. (1862), pp. I84-5. 
the single dead-shell referred to. He had picked up the specimen while collecting mosses on the Newcastle sandhills, but only discovered it (at the roots of a tuft of a Hypmem) when he proceeded to examine the contents of his vasculum, at Belfast, in the cvening; subsequent searches on the same sandhills had proved unsuccessful, and therefore he did not regard the species as British, and was of opinion that its name ought to be cxcluded from our lists. It was improbable, he thought, that the specimen had been imported with ballast, for there were no ballast-heaps about the little port, and the shell was found a long way from the quay; but, as he added, "Ncwcastle is onc of the most popular watering places in the North of Ireland, and it is no unusual occurrence for people to stop there for a time who have also been at watcring places on the continent. Shell collecting is onc of the amuscments of such resorts, and it is quite likely that some person, having foreign shells, dropped the specimcn about which I write." '

Bulinus exilis Gmel. A dead shell of this animal, a West Indian species, found on the shores of Lough Carra, county Mayo, Ireland, was recently exhibited at the Conchological Society on behalf of Miss Warren." The specimen was gathered by one of her friends from amongst quantitics of dead shells cast up on the shores, and its prescnce in such a locality is certainly surprising, especially as Carra is an inland

' J. G. Jeffreys, "Ann. and Mag. Nat. Hist.," (4), vi. (1870), pp. 423-4 ; S. A. Stewart, "Science Gossip," xix. (1883), p. I 59.

2 Proc. Conch. Soc., "Journ. of Conch.," vi. (I89I), p. 387. 
lake. Miss Warren suggests that it may have been a collection-escape. No one residing in the neighbourhood, however, is known to possess West Indian shells, but, by one means or another, quite possibly, the specimen may have been carried, perhaps by a stream, from a considerable distance.

Bulimus undatus Brug. Sir C. Lyell, in the "Principles," stated that B. undatus, a West Indian shell of considerable size, had been imported, adhering to tropical timber, into Liverpool, and, as mentioned in the last chapter, he was informed by Mr. Broderip that the creature had become "naturalized in the woods near that town." It can hardly be assumed, I think, that the animal is, or ever was, really acclimatized here; Gray, however, in 1840 , and again in 1857 , speaking of it as $B$. zebre, mentioned its importation with mahogany logs, and remarked that it often lived for some time in this country. I am not aware that specimens have been found during recent years. ${ }^{1}$

Bulinus Detritus Müll. In isSo or ISSi, Dr. P. B. Mason wrote to the "Journal of Conchology" that more than a dozen specimens of $B$. detritus, in various stages of growth, most of which were alive when found, had recently been brought to him as having been taken from a rockery in a garden in the neighbourhood of Burton-on-Trent. They occurred among a number of dead littcral shells, gathered at Scarborough, with which the owner of the garden was certain they had

1 "Principles," ii. p. 371 ; Gray's "Turton," I840, p. 7 ; I857, p. 292. 
been introduced. But it is, of course, unlikely that this was the casc, sceing that the shell is a native of central and southern Europe; and it seems that its presence can be accounted for in another way, for Dr. Mason ascertained that a quantity of light barley and other seeds (screened out of some samples of barley intended for malting purposes) had been brought into the garden for the purpose of feeding poultry; and a sample of screenings which he subsequently procured, as already mentioned, contained living shells of Helix caperata. ${ }^{1}$

Bulines DeCollatus L., a Mediterranean and now widely distributed species, once found a place in British catalogues, having been imported, it can hardly be doubted, with plants. Turton, in his "Conchological Notices," of I 826 , stated that the creatures had been observed to breed in great abundance for many successive years at Watton, in the south of Devon, the seat of $\mathrm{H}$. Studdy, Esq. They were lodged in the earth under the wood-work of a green-house, whence they wandered abroad in summer; at last, however, when the woodwork and the earth were removed, the colony was lost, "and all that were preserved we owe to the care of Mrs. Griffiths and Miss Hill." In the "Manual," in I83I, Turton added that no foreign earth was ever known to have been admitted into the green-house, and that the animals were considered by the gardeners as natives. Mr. Alder, in I838, however, remarked that the species could not be regarded as British, and Gray seems to have

'P. B. Mason, "Journ. of Conch.," iii. (I $880-2)$, p. I I $S$. 
finally cxcluded it from our lists in his "Turton " of I 840 , observing that it was not even naturalized or acclimatized, for it occurred only in hot-houses warmed with artificial heat. ${ }^{1}$

Mr. W. Borrer tells me that many years ago the late Sir W. Hooker gave him specimens of this mollusc (together with B. goodallii) from the Royal Gardens at Kew.

Bulimus octonus Chemn,, a West Indian and Central American species, is said to occur in greenhouses in this country. It has been recorded from near Manchester, etc."

Clausilia Papillaris Miill., of southern Europe, seems to have found a place among our native shells at one time. As stated by Mr. Alder, however, a manuscript copy of Laskey's "North British Testacea," consulted by Forbes, was found to "fully explain the history of the British C. papillaris." The creature occurred, it appears, in Granton Park, near Edinburgh, to which place it had becn imported from abroad in moss round the roots of some exotics. ${ }^{3}$

Clausilia SOlida Drap. Of this species, also a native of southern Europe, a single specimen (figured in the supplement to the "British Conchology") is said to have been found at Stapleton, near Bristol, by Mr.

1 Turton, "Zoological Journal," ii. (IS26), p. 565 ; "Manual," I831, p. 79 ; Alder, "Mag. Zool. Bot.," ii. (1838), p. Iro; Gray's "Turton," 1840, p. 184 .

2 T. D. A. Cockerell, "Science Gossip," I 893, p. 26.

3 J. Alder, "Mag. Zool. Bot.," ii. ( 1838 ), I I I. 
Rich. There are extensive nursery grounds in the locality, and it is probable, as Mr. Rimmer has suggested, that the shell was brought from the Continent in the roots of plants or among moss. ${ }^{1}$

Clausilia parvula Studer. Varieties of our common C. rugosa have several times been incorrectly referred to this species, which on this account long ago received a place in our catalogues. The true C. parvula, it is stated in the "British Conchology" (I 862), "inhabits the North of France, as well as every other part of the Continent, and may be expected also to be found in Great Britain," and in fulfilment of this expectation, as appears by the supplement to the fifth volume (I869), several specimens have been found by Mr. Grant Allen, at Kinver, near Stourbridge; these, however, it has been suggested, were, in all likelihood, "accidentally or intentionally imported from the continent." = Both this and the last species werc excluded from the Conchological Socicty's list of I883, as not having the slightest claim to rank as British. Continental specimens of both have been turned out by Mr. Baillie, near Brora, Sutherlandshire.

Many other foreign molluscs, no doubt, have occurred

1 "Jeffreys," v. (I869), Supplement, p. I62, pl. xcix. fig. 2; “Rimmer," I880, p. 178.

2 Gray's "Turton," I 857, pp. 186-8; Alder, "Magr. Zool. Bot.," ii. (I838), p.I I I ; “Jeffreys," i. (I862), p. 280; v. (I869), Supplement, p. I6I, pl.xcix. fig. I ; "Rimmer," I880, pp. I I7-18; J. T. Marshall, "Science Gossip," xviii. (1882), p. 261. 
from time to time, especially in gardens and greenhouses. The finding of two Parmacella-slugs in a garden near Newcastle, of a living shell of Helicinc amence in a nurscry at Holloway, and of three exotic land-shells in an orchid-house in Nottingham was referred to in the preceding chapter. No doubt they occur, also, somewhat frequently in shops and warehouses, generally dead, but sometimes, as in the case of Hclix vermiculata at Barnsley, in a living state. A grocer at Louth once gave me dead shells of Helix virgate (from amongst raisins) and Helix cespitum (from a bag of nuts), and he afterwards found other species. It is probable also that many kinds, brought over from abroad, or received from foreign correspondents, like the Helices and Clausilice above referred to, or mentioned in the preceding chapter, have been intentionally turned out. Helix terrestris, which may possibly obtain a permanent footing, was very probably thus introduced, and it has been recently transplanted by the Rev. J. W. Horsley to his garden at Woolwich. Some South American snails, as already noticed, turned out in an English garden, are known to have survived at least for three or four years. 



\section{N D E X.}

A.

ABERDARE, sliower of fish in valley of, 43 .

Accrington, Pupa cinerea near, 234.

Achatinelline, restricted specific ranges in, 9I, 96 .

Acilins, snail's eggs attached to, 47.

bivalve clinging to, 65 .

Ancjlus adhering to, 87 .

Adami, G. B., colonization by, 192.

Adams, L. E., on a flood in the Thames, 3 I.

on bivalves clinging to newts, 71 .

on Helix vermiculata at Barnsley, 255.

Adams, Professor, on weight of V'ertigo milium, I 47.

Adanson, on shells in swamps, 24.

Additions to the fauma of a pond, I 4.

Estivation, climatic barriers overcome by, 100.

dispersal during, 148.

Alder, J., on introduced or doubtfully indigenous shells in Britain : on Dreissena polymorpha, 2 I 3 .

on Testacella mangei, 228.

on Bulimus goodallii, 230.

on Testacella haliotider, 250.

on Helix limbata, $25 \mathrm{I}$.

on Clanesilia papillaris, 261.
Alexandra Park, Mancliester, shells in lake at, $\mathbf{r} 9$.

Allen, Grant, on Clansilia parvula near Stourbridge, 262.

Alluvium, shells in, I4I.

Amalia, attempted colonization of, 195.

Amazons, floating pumice of, 125 , I.39.

rafts of, I 29, I 30.

Amplibia, dispersal by, 69,88 .

wandering habits of, 75 .

climbing powers of, 76 .

And see frogs, newts, and toads.

Ampullarice, tenacity of life of, $2 S$.

Ancylus, Reeve on the means of dispersal of, 86.

adhering to water-beetles, 86 .

possibly dispersed with mussels, 88 .

Ancylus fuviatilis, carried away by a flood, 3 I.

adliering to water-beetles, $S_{7}$. to mussels, 88 .

ova of, attached to a waterbeetle, 47 .

A. lacnstris, adhering to a waterbeetle, 87 .

adhering to a frog, 89 .

Animals, dispersal by, 45, 154, 174, I 78, 209.

living molluscs (or ova) passing the digestive systems of, 45,46 .

possibly scattered from the stomaclis of, by birds of prey, 45, I 59, I76. 
or ejected from the crops of frightened birds, 45, 163 .

Anolonta, tenacity of life of, $2 S$, $4 \mathrm{I}$.

shower of, 44 .

dispersal of fry of, 48 .

clinging by closure to various objects, 57.

to a redshank, 79 .

to a duck, 79 .

to a water-vole, $S_{3}$.

Anodonta or Unio, clinging to a sandpiper, 79 .

to a heron, So.

to a duck, So.

Anodonta cygnea and frost, 4 I.

A. furviatilis, in hole formed by peat-digging, is.

Anthony, Mr., on Planorbis dilatatus in Britain, 222.

Antiquity, 3, I I 5, I73.

Ants, on drift-wood, I 38 .

Aplin, O. V., shells not seen upon birds' feet by, 50 .

on tenacity of life in a landsnail, IoS.

on a nagpie killing snails before swallowing them, I 60.

on barley scattered from a bird's crop, I 62.

Arboreal snails, dispersal of, I 36.

Arbuthnot, General, said to liave imported Helix pcmatia, 244.

Arion, tenacity of life of, 166.

Arion ater, carried by a river, I 70.

Artesian wells, 22.

Arundel, Earl of, said to have imported Helix pomatia, 244.

Ashford, C., on the transportal of Sucrinea futris by floods, I 42 .

on colonization of Helix pomatia, I 86.

on bulimus soodallii in Britain, 23 I.

Astacus, bivalves clinging to by closure of the valves, $\delta_{3}$.

by the byssus, 84 .
Atchafalaya, great raft of, 129.

Atkinson, J. C., shells not seen upon birds' feet by, 50 .

Atlantic, birds blown across the, I 56.

Aucapitaine, Baron, on tenacity of life in a snail, I05.

experiments with snails and sea-water, I2I.

Austen. See Godwin-Austen.

Australasia, introduced slugs in, I 78 , I So.

Australia, dust whirlwinds of, I49.

Limax lavis in, I73, I78.

Helix aspersa in, I So.

Azores, land-shells of, 93.

absence of fresh-water shells in, 93 .

birds blown from Europe to, I 56 .

shells probably carried to, liy birds, I 59.

B.

BAILLIE, W., colonization by, I 85 , I 9I, I 95, 262.

Baird, Dr., on tenacity of life in the desert snail, 102.

on the Guernsey specimen of Helix aperia, 256.

Ballast, dispersal with, I96, I97, $245,246,247,252,253$, 254 .

Baltic timber, dispersal with, $2 \mathbf{I}$.

Bamboos, snails in hollows of, I 4 O.

Bananas, dispersal with, 20 I, 207.

Barley, scattered from the crop of a bird, 162 .

Barley for malting, smails amongst screenings from, $20 \mathrm{I}, 260$.

liarriers, I, 2, IOO, II 5, I 72.

liates, II. IV., on dispersal by floating pumice, I 24, I39.

beagle, beetle flying on board the, 69.

Beasts of prey, dispersal by means of, 45 .

Becher, E. F., on Limmee in puddles, 24. 
Bee, snail clinging to, 85,165 .

Beetles, showers of, 44 .

snail's eggs attached to, 47 .

bivalyes clinging to, 63 .

flying habits of, 66, 69 .

carrying powers of, 67 .

caught on the wing with shells attached, 68, 87 .

dispersal of ninivalves by, 85 , 86,155 .

And see Acilius, Dy'tiscus, and Coly'mbetes.

Beevers, I., on additions to the fauna of a pond, 15.

Belt, T., on dispersal of land-shells, 95.

on the difference in the distribution of fresh-water and land-shells, 97, 98 .

on whirlwinds, 149.

Benson, W. H., on tenacity of life in a Cyclophorus, II 4 .

Berkeley, MI. J., on Dreissena polymortha in Britain, 213, 216.

Bingley, a ease of long suspended vitality recorded by, Ioo.

Binney, A., on a snail reviving after being frozen, $4 \mathrm{I}$.

on tenacity of life in the desert. snail, 103.'

on voluntary migration, I 6 .

on drift wood, I 27.

on dispersal by currents, I37, 144 .

on Bulimus decollatus destroying Helix nemoralis, 194.

on dispersal with ballast, 196 .

on the importation of snails into the United States for food, 203.

Binney, W. G., on the distribution of Bulimus undatus, ${ }_{3} 8$.

on river-dispersal, 142.

colonization lyy, Iso, 193, 194.

Bird, claw of, found between the valves of a mussel, 77.

Birds, dispersal by, 45, 77, 156, $174,224$. shells possibly scaltered from the crops of, 45, I 59, I 76 .

ejection of contents of crops of, $45,163$.

rate of Hight of, $47,49,159$, 177.

shot on the wing with shells and ova altached, 47, 79 .

dispersal with plants and earth adhering to, $5 \mathrm{I}, 54, \mathrm{I} 57$.

marine bivalves elinging to, 58.

snails killed before being swallowed by, I6o.

Birds, dead, float on the oeean possibly with molluses in their elops, I $63,177$.

Birds of prey, dispersal by means of, 45 , I 59.

Birmingham, Dreissena polymorplia in water-pipes at, $\mathbf{I} 9$.

Bivalves, voluntary migration of, 4 . out of water, 4,33 .

in isolated waters, $6,8, \mathbf{1} 2$.

effects of frost upon, 41,42 .

dispersal of, while clinging by closure of the valves, 56 .

And see Molluscs.

Blackbird, claw of, between the valves of a mussel, 78 .

Blackibirds, probable destruction of snail-eolonies by, I 9 I.

Black slug. See Arion ater.

Ijomefield, L., on snails eating into a pollard-elm, I 32 , 135 .

on Helix fomatia in Britain, 241.

Bones, shells amongst, 202.

Borrer, W., on Rulimus goodallii and $B$. decollatus at Kev, $23 \mathrm{I}, 26 \mathrm{I}$.

bouehard-Chantereaux on suails falling from trees with leaver, 147.

bourguignat, J. R., on colonization of lielix lactea, IS9.

Brackish water, fresh-water shells living in, 39 .

Bracier, J., on dispersal by currents, 133 . 
Brazil, observation by Darwin in, 29. Brick-pits, shells in, I 7 .

Bridgman, IV. K., Planorlis nautileus found among floating weed, 34.

$P$. nitidus and a Valvata amongst confervoid vegetation, 52.

Bristol, Testacella mangei near, 228.

Bulimus goodallii near, 230.

Clansilia solida near, $26 \mathrm{I}$.

British Isles, introduced molluscs established in:

Dreissena polymortha, I S I, 209, 210.

Planorbis dilatatus, 209, 22 I.

Physa acuta, 224.

Testacella mangei, 288.

Bulimus goodallii (in greenhouses), 229.

Ilelix terrestris, 232.

the occurrence of other species foreign to the fauna of, 226 , 234,251 .

doubtfully indigenous species in, 209, 234 et seq.

specimens of the indigenous Planorlis glaber perhaps introduced into, 2 ro.

British land and fresh-water shells,

Conchological Society's list of, 209, 227.

British Museum, specimens illts. trating means of dispersal exhibited in, 74, 78, 8I.

the Guernsey specimen of Helix aperta not to be found in, 256 .

Hroderip, Mr., snail revived by, I 2 .

on the supposed naturalization of Bulimus nndatus near Liverpool, 202, 259.

Brown, Captain, on Dreissena polymorpha in Britain, 213, 2 IS.

on Helix pomatia in Britain, 240.

Brown, R., on dispersal by ice, I 23.

by floating timber, I 39 .
Bryant, J., Dreissena polymorpha, discovered in Britain by, 2 I I .

Buckland, Mr., rail caught by an oyster, 60.

Buenos Ayres, Helix pomatia at, I 79.

snails from, colonized in Yorkshire, 192, 202.

Helix lactea in markets at, 204.

Building materials, dispersal with, I 98 .

Butimi, carried with dye-woods, $201,202$.

Bulimus decollatus, attempted colonization of, in New Jersey, I 93.

destruction of snails by, I94.

in Britain, 260.

b. detritus, at Burton-on-Trent, 259.

B. ediuardsianus, carried to New Caledonia as an article of food, 203.

b. eremita, tenacity of life of, I 3 .

B. exilis, in Ireland, 258 .

$B$. fasciatus, probable dispersal of, by currents, I 37 .

B. goodallii, in Britain, 229.

$B$. octonus, in Britain, 26 $\mathrm{I}$.

B. pallidior, tenacity of life of, I I I.

$B$. rosacens, tenacity of life of, I 2.

b. undatus, probable dispersal of, by currents, I 37 .

Mr. Binney on the distribution of, I38.

carried with tropical timber, $20 \mathrm{r}$.

its supposed naturalization near Liverpool, 202, 259.

b. sebra. See b. undatus.

Bulinus. See Physa gibbosa.

Ijuriton, discovery of Ilelix obwoluta near, 247.

Burnley, Planorbis clilatatus at, 223.

Bythinia, clinging to the larva of a dragon-fly, 85 . 
C.

CADDis-CASES, shells upon, I4, 35 . dispersal of shells with empty cases, 35 .

Canals, dispersal by means of, I96, 2 I $5,202$.

Canoes, drifting on the ocean, I 28.

Cape, Helix aspersa at the, I 79, 204, 243 .

Cardiff, imported snails near, 246 , 253.

Carrington, J. T.,on Helix terrestris in Britain, 233.

Carson, J., on introduced slugs in Victoria, I So.

Carychium mimmum, in kexes, I 40.

amongst leaves, $\mathbf{I} 47$.

Cattle, dispersal by, I 2, I 56.

Cattle-bone, shells amongst, 202.

Cattle ponds. See ponds.

Cattle-troughs. See troughs.

Census of the distribution of British land and fresh-water shells, 219.

Centres of "creation," single, I. multiple, 2, 5, I IS, I 23 .

Chalk, dispersal with, I97.

Chapman, Abel, shells not seen upon birds' feet by, 50 .

on living cockles in birds' crops, $16 \mathbf{r}$.

Chapman, H. V., on a bivalve carried by a snipe, $S_{I}$.

Chelyutra, mussel carried lyy, $\delta_{3}$.

Chemist's shop, foreign snail in, $201,255$.

Chichester, colonization near, I 88 , I 94.

Chislehurst, colonization at, I 86 , I 94.

Choules, A., Phy'sa acuta cliscovered in Britain by, 224.

Christy, R. M., on tenacity of life in Paludina, 28.

Churcli, pond-snail on the tower of a, 5,165 .

Cistern, shells in, 20.

City Roal, shells in water-pipes of, 19.
Clausilia (or Cyclostoma) clinging to a bee, I 66.

Clausilia fapillaris in Britain, 26I.

C. farvula in Britain, 202.

C. megosa, tenacity of life of, I I 3 .

C. solida near Bristol, $26 \mathrm{I}$.

Clausilia living under the bark of trees, I 32.

Climate, changes of, I 7.

Climatic barriers, how overcome, I OO.

Coal measures of Nova Scotia, fossil land-shells of, I I 5 .

Cochlicopa lubrica amongst leaves, I 46.

Cockerell, T. D. A., Helix pomatia colonized by, I $\$ 6$.

on Physa acuta at Kew, 225.

Cockle, clinging to dunlins, 59 .

to a tern, 59 .

to a peewit, 59 .

to sandpipers, 60 .

to a snipe, 60 .

to a sanderling, 60 .

Cockles alive in birds' crops, I6 I.

Cocoanut-husks, floating, dispersal by, I 33, I 34 .

Cocoons of Testacella, I68.

Collectors, dispersal by, I 3, I6, $25 \mathrm{~S}$.

Colletl, R., on colonization of Heliv. pomatia, I $\$ 7$.

Collier, E., on Planorbis dilatatus and Helix villosa in Britain, 222, 254 .

Collings, Mrs., on an attempt in colonize Helix pisana, IS9.

Colonies, difficulties attending the establishment of, $\mathrm{S}_{2}, 96$, I 19 , I $22, \mathrm{I} 64, \mathrm{I} 75$.

isolated, of land-shells, 94 .

Colonization of molluscs by man, $23,{ }_{2}, 205,263$.

Columbia river, probable dispersal by, I 42 .

Colymbetes flying on boarl the beagle, 69.

Commercial docks, Thames, discovery of Dreissena folymorpha in, 2I I, 215.

Concliological Society's lint, 209, 227. 
Confervoid vegetation, shells amongst, 52 .

slug carricd by a floating mass of, I 70 .

Congo, rafts of, I 29.

Continental extcnsions, hypothetical, I I $S$.

Continents, general permanence of, I 18.

Cooke, A. H., on Helix pisana in Guernsey, I 90.

on Physa acuta at Kew, 225.

Cooper, Thomas, on a shower of frogs, 44 .

Cordeaux, J., shclls not seen upon birds' feet, by 50 .

shells noticed among duckweed by, 52 .

on shells in birds' crops, I6o, I6 I - 2 .

on dispersal by thrushes, 165.

Corixa, bivalves clinging to, 63 .

Cormorant caught by an oyster, $6 \mathbf{I}$.

Cotton, supposed dispersal with, 22 I.

Cox, C. S. B., on Helix terrestris in Britain, 232.

Crayfish, bivalves clinging to, $\delta_{3}$, 84 .

Creation, centres of, $\mathrm{I}, 2$.

Cresswell, F., on a tern caught by a mussel, 60 .

Crick, IV. D., on mussels clinging by closure, 58 .

on a Spharium clinging to a water-beetle, 63 .

to a frog, 73 .

Crops of birds, molluscs carried in, 45 , I 59, I 76.

Helix caperata alive in the crop of a pigeon, I6I, I63.

living cockles in the crops of curlcws, I6I.

Crow caught by a mussel, 60 .

Cucumber-housc, Bulimus goodallii in, $23 \mathrm{I}$.

Cuming, Mr., on a Cyclas probably carricd by a flood, 33 .

Curlew sandpiper, cockle clinging to, 60 .
Curlews, living cockles in crops of, I6I.

Currents, fresh-water, dispersal by, I $8,21,23,30,37,124,138$, I69, I70, 224.

ratc of, in $\Lambda$ mazons, 125.

marinc, dispersal by, 37, 120 , I63, I 74, I77.

rate of, $\mathrm{I} 2 \mathrm{I}$.

Curtis, J., on dispersal by waterbeetles, 67 .

on tenacity of life in snails, I I3, I I 4 .

Cyclas probably carried by a flond, 33.

And see Spherium.

Cyclones, I 49 .

Cyclophorus indicus, tenacity of life of, I I 4 .

Cyclostoma (or Clausitia) clinging to a bec, I66.

Cyclostoma elegans, isolated colonies of, 95 .

reviving after submersion in sea-watcr, I 2 I.

Cyclostomas, tenacity of life of, II 3 .

D.

Da Costa, E. M., on Helix poma. tia in Britain, 235.

Da Costa, S. J., on Helix obroluta in Surrey, 248.

Dalton, J., on the occurrence of freshwater shells in unlikely spots, 5 .

on an isolated pond, I7.

on the spreading of Dreissena polymorpha, 220.

Daniel, Mr., on snails falling from trecs with leaves, I47.

Darbishire, R. D., on tenacity of life in a land-snail, ro5.

on colonization near Manchester, I85.

Darwin, C., on single centres of "creation," r.

on land as a barricr to freshwater sliclls, 3 . 
on the wide distribution of freshwater shells, 4 .

on the dispersal of freshwater organisms, 29.

on the difference in the distribution of freshwatel and land shells, 29, 97.

on changes of level, 30, I I 7 .

on salt-water killing snails, 40.

on fish carried by whirlwinds, 43.

on the dispersal of eggs of freshwater shells, 46.

experiment with a duck's feet in an aquarium, 49.

on shells carried with duckweed, $5 \mathrm{I}$.

on earth adhering to birds, 54, I $5^{8}$.

on bivalves clinging to waterbeetles, 63,64 .

on the flying habits of waterbeetles, $66,67,69$.

on their carrying powers, 67 .

on a Unio clinging to a teal, So.

on dispersal by birds, 82,156 , I 77.

on an Ancylus adhering to a Dytiscus, 87.

on wide ranges, 95 .

on changes of climate, I I 7 .

on hypothetical continental extensions, I I 8 .

on dispersal by ocean currents, I 20.

experiments with smails and sea-water, I 20.

on dispersal by icebergs, I23.

on floating timber, I 26, I 28 , I 35 .

on dispersal of the young of land-snails, I 57.

on organisms carried in bircls' crops, I 59, I 62.

on dead birds floating on the sen, 163 .

Darwin, F., on C. Darwin's experiment with a duck's feet in an aquarium, 49. on mussels clinging by closure, 58.

Davy, J. B., on isolated ponds, I I, I 2 .

on bivalves clinging to frogs, 74 .

on Phy'sa acuta at Kew, 225.

Denbighshire, shower of hay in, I 53.

Denmark, attempted colonization of Helix pomalia in, I 87 .

Descent, monophyletic, I.

polyphyletic, 3 .

Dickens, an allusion to winddispersal by, I 54 .

Digby, Sir K., said to have im. ported Helix pomatic, 235.

Dikes, W. H., shells in a bird's crop, I6o.

Dispersal, of freshwater shells, 27 .

of bivalves while clinging by closure of their valves, 56 .

of operculates while clinging by closure of the operculum, 85, I 65.

of freshwater univalves while adhering to other animals, 86.

of land-shells, 95, I I 5 .

scarcity of evidence of, I I9, I 72.

habitats conducive to, 34,37 , $52,132,140,146,169,17 \mathrm{I}$, 173.

of slugs, 167.

Dispersal by man, I 56, I 78, 209.

Distribution, local, 1, 5, 23, 82, 94, I64.

ciscontinusus ranges, 2, 92, I 73 .

freshwater shells alosent from some oceanic islands, 93.

reasons for the differences in the distribution of freshwater and land shells, 95.

small smails, and operculates, range more widely than large inoperculate snails, I 36 .

Distribution of freshwater species, wide, 4 .

of land species, restricted, 90. 
of land genera sometimes wide, 92.

of British land and freshwater shells, "Census" of, 219.

Donovan, on Helix pomatic in Britain, 237.

Doubleday, H., on wandering of frogs, 75 .

Douglas, R. C., on a bivalve clinging to a toad, 74 .

Dover, Helix terrestris near, 232.

Downs, isolated ponds of, 6 .

Dragon-fly larva, Sphorium clinging to, 6I.

Bythinia clinging to, 85 .

Drane, R., on a shower of fish, 43 .

Dreissena polymorpha carried with water, 18.

found in London streets, IS.

in water-pipes, I8.

dispersal of fry of, 36, 49, 220.

sometimes attached to crayfishes, 84 .

its rapid diffusion: I8I, 2I4, $217,219$.

its British history, 210.

its tenacity of life, 2 II.

its occurrence in unnavigable water, 217 .

in new water, 220.

its range in Britain, 2 I 9.

Dresser, H. E., shells not seen on birds' feet by, 49.

Drift-wood. See T'imber, floating.

Drummond, T., on Testacella maugeiand Bulimus goodallii in Britain, 228, 230.

Dry-bulls, dispersal with, I98.

Duck, a snail's eggs on the foot of, $47, \mathrm{I} 57$.

experiment with the feet of, in an aquarium, 49.

a leech clinging to, 50 .

caught by an otter's shell, 60 .

by mussels, $77,79,80$.

Ducklings, caught by Uniones, 77 .

Duckweed, dispersal with, 5 I.

Dumfriesshire, shower of leaves in, I 48,153 .

Dunlins, cockles clinging to, 59 .
Duprey, E., on Ancylus adhering to water-beetles, 87 .

Durham, Helix villosa and Helix lapicida in, I93.

Dye-woods, dispersal with, 20I, 202.

Dyer, Mrs., on Helix pisana near Swansea, I 89.

Dyson, Mr., on Dreissena poly'morpha in water-pipes, IS.

Dy'tiscus, bivalves clinging to, 63 et seq.

the flying habits of, 66 .

the carrying powers of, 67 .

flying with shells attached, 68, 87 .

Ancylus adhering to, 86, 87.

\section{E.}

EAGLes, probable dispersal by means of, 160 .

Larth, dispersal with : by birds, 54 , I 57 .

by floating trees, I $29,133,136$, I69, I 7 I, I 74 .

by cattle, 156 .

l)y man, I98, 200, 207, 250 .

Eastbourne, snails in the gardens of the martello towers near, I 98.

Edible snail. See IYelix pomatia.

Edible snails, dispersal of, 203, 235, $236,240,257$.

Eggss, deposited by snails after dormant periods, 104, 107, 109, I 22.

of Limax in a tree-trunk, 173 .

dispersal of: of freshwater molluscs, 36, 39, 41, 46, I 24 .

of land molluscs, I2O, I23, $124,126,138,139,145,152$, $153,157,158,164,169,172$, $173,174,200,207$.

Eric Canal, molluscs colonized in, I 84 .

Esmark, Miss, molluscs colonized ly, 184,187 .

dispersal with ballast, 197. 
Esparto-grass, possible dispersal with, 254.

Establishment of new colonies, difficulties attending, $\mathrm{S}_{2}, 96$, $119,122,164,175$.

European snails, exported as delicacies, 203.

carried by ships as part of provisions, 203 .

widely dispersed by man, I $7 \mathrm{~S}$.

F.

Faunas, insular, richness of, increased by time, 123.

Fewkes, J. W., on a bivalve clinging to a duck, 80.

Field-slug. See Limax agrestis.

Fierke, F. IV., on an isolated pond, IO.

Finchley, isolated ponds at, 13 .

Fish, showers of, 43 .

dispersal of fry of Unionidx by, 48 .

bivalves closing upon, $5 \mathrm{~S}$.

possible clispersal with, by human agency, 226.

Fish-ova, dispersal with, 195.

Fleming, J., on Dreissena poly'morplia and Helix pomatia in Britain, $213,238$.

Floating of certain land-shells in water, 140.

Floating luusks, dispersal by, 133 , I 34 .

Floating ice, dispersal by, 4I, 123.

Floating islands, $129,136,137$, I 74 .

animals secn on, 130 .

pumas landed by means of, 130 .

Lycll on the landing of, I 3 I, I 36,174 .

Floating molluscs, dispersal of, 35 .

Floating pumice, I42, $139,174$.

Floating timber. See Timber, floating.

Flood-water, shells in, 33 .

Floods. See Currents.

Flower-pots, dispersal in, 200.
Food, dispersal of molluses for, $203,235,236,240,257$.

Forbes, E., oceans bridged over by, I 7 .

on clispersal by means of canals, 196.

on dispersal by man, 209.

on Helix pomatia in Britain, 239.

Helix aperta found in Guernsey by, 256 .

Forbes and Hanley, on Dreissena polymorpha and Helix pomatica in Britain, $213,240$.

Ford, John, on dispersal with bananas, $20 \mathrm{I}$.

Ford, Mr. (Redhill), on a mussel clinging to a sandpiper, 79 .

Fountains in Trafalgar Square, shells in, 22.

Fowler, Canon, on the flying habits of water-beetles, 66 .

Foxes, mussel and oyster closing upon the tongues of, 58 .

snail-colonies probably exterminated by, 187 .

Frankfort, Helix acuta carried to, 200.

Franklin, Dr., a whirlwind de. scribed by, 149.

French men-of-war, dispersal of "escargots" by, 205, 206.

French sailor, the Guernsey specimen of Helix aperta perhaps clropped by a, 257.

Fresh-water limpets. See Ancylus.

Fresh-water mussels. See Allodonta and Unio.

liresh-water organisms, derived from the sea, 3 .

destroyed by changes of level, 99.

Firesh-water shells. See Molluscs.

Fresli-waters, want of continuity of, 98.

Frogs, showers of, $43,44$.

living bivalves in stomachs of, 45 .

bivalves clinging to, 72,76 .

wandering habits of, 75 . 
climbing powers of, 76 . Ancylus adhering to, S9.

Frozen mud, dispersal in, 42.

Fry, dispersal of, $36,46,48, \mathbf{5} 7$, I 74, 220.

Fryer, Mr., on Helix cantiana, 245.

\section{G.}

GAIx, IV. A., on snails reviving after being frozen, 4I .

Gallwey. See Payne-Gallwey.

Ganges, rafts of, I 29.

Garden-snail. See Helix aspersa.

Garner, Mr., on the dispersal of Dreissena polymorpha, 2 I I.

Gaskoin, J. S., on tenacity of life in land-snails, I 04, I09.

on the production of eggs by snails after dormant periods, 104, IO9, I 22.

Gecko. See Lizard.

Germany, Dreissena polymorpha in, $2 \mathrm{I} 2,2 \mathrm{I} 4$.

Gibuons, J. S., on Helix aspersa near Cape Town, I79.

on Hyalinia cellaria in $\mathrm{St}$. Helena, I 79 .

Girard, Professor, on bivalves clinging to crayfishes, 83 .

Glacial epoch, dispersal during, 30 , 123.

Gloyne, C. P., on shells in cemented tanks, 22.

Godman, F. Du C., on birds blown to the Azores, I 56.

Godwin-Austen, H. H., on the dispersal of eggs of fresh-water shells, 46 .

on the finding of a bird's claw between the valves of a mussel, 77 .

Gold-fish, possible dispersal hy man with, 226.

Goodridge, C., on drift-wood, I 34.

Gorton, shells in lake at, I9.

Gould, Dr., on shells amongst leaves, I46.
Goulding, R. IV., on a bivalve clinging to a newt, 70 .

to a frog, 73 .

Gray, A. H., on a Unio clinging to a teal, So.

Gray, J. E., on the exportation of snails as delicacies, 203.

on Dreissena polymorpha in Britain, 2 I I.

on Helix pomatia, H. cantiana, and $H$. obvoluta in Britain, $239,245,247$.

on the occurrence of exotic shells in the British Isles, 25I, 256, 259, 26I.

Great water-beetle. See Dytiscus. Girecnlouses, foreign snails in, I98, 230, 260, 26I.

Griffith, J., on a shower of fish, 44.

Grocer's shop, foreign snails in, 263.

Grocock, Mr., on Physa acula in Britain, 225.

Gude, G. K., on tenacity of life in snails, IOS, I I J.

on the finding of a Helicina among orchicls, I99.

Guernsey, attempt to colonize Helix pomatia in, IS7.

Itelix pisana colonized in, I 89 . Helix aperta found in, 256.

Gulick, J. T., on restricted specific ranges, $9 \mathrm{I}$.

Gum Arabic, shell amongst, $20 \mathrm{I}$.

Guppy, H. B., experiment with Neritina and salt-water, 40.

on dispersal in frozen mud, 42.

Gurney, J. H., on bivalves clinging to birds, 6o, 79 .

Gwatkin, H. M., on Hclix pisana in Guernsey, Ino.

I.

Habitats conducive to dispersal, $34,37,52$, I 32, I 40, I 46 , 169, 17 I, I 73 . 
Ilancock, Mr., on cockles clingingr to birds, 59.

Hardy, J. R., on earth adhering to birds, 54 .

on bivalves clinging to the larva of a dragon-fly and to a water-scorpion, 62 .

to a water-beetle, 65 .

to newts, $7 \mathrm{I}, 76$.

to frogs, 73 .

to a water-vole, $S_{3}$.

on an operculate water-snail clinging to the larva of a dragon-fly, 85 .

on Aucylus adhering to Dytiscus, 87 .

IIarting, J. E., on Ilelix pomatia at Petersficld, is7.

on Dreissena polymorpha in Britain, 2I3.

Hatton, Lord, attempted colonization of Ilelix pomatia by, I 87,236 .

IIawker, W. II., on British localities for Helix obvoluta, 248.

II awks, probable dispersal by means of, I 59, I6I-2.

Hay, carried up by whirlwinds, I 5 I, I 53 .

showers of, I 53.

lleart-cockles, clinging to fishhooks, 5 S.

Heathcote, $\mathrm{WT}$. H., a Limnea seen on the tower of a church by, 5,165 .

on a bivalve clinging to a beetle, 64 .

to newts, 70 .

colonization by, I85, I 90.

on Hyalinia draparnaldi at Preston, I99.

Iledgehogs, snail-colonies probably exterminated by, IS7, IS8.

Iledley, C., on introdluced slugs in Australasia, 178 .

on Helix aspersa in Australia, I So.

on wide dispersal of slugs, 206.

on Limax. maximus in Tasmania, 207.
I Ieilprin, Professor, on diffusion of land-shells, I I 9 .

Helicarion, carried by a beetle, I 55 .

Helicide, wide range of, 92.

Helicina amana, carried from Brazil with orchids, I99, 263.

Helix, wide range of, 92.

killed by sea-water, I2I.

carried with Sphagmmm, I99.

with cattle-bone, 202.

on the floating or sinking of in

water, I 40 .

Helix aculeata, a mongst leaves, I47 . falling from trees with leaves, I 47 .

H. acuta, carried on palm-trunks, 200.

H. alanda, carried with bananas, 201.

II. anmulus, probable dispersal of, by currents, I 33 .

H. aperta, tenacity of life of, 105.

in Gucrnsey, 256.

H. appressa, colonization of, 193 .

II. aspersa, in Australia, I4O, ISO.

at the Cape, I 79, 204, 243.

in Nadeira, I 79.

in the Loyalty Islands, 205.

suspended vitality in, 107.

production of eggs by, after a dormant period, 107 .

found in cut bamboos, I 40.

carried by a bird, I65.

found in imported sand, I97. carried by ships as part of pro. visions, 203 .

imported into the United States as an article of food, 203.

1/. austriaca, colonization of, 193 .

II. licarimata, tenacity of life of, I IO, I I I.

H. can lidissima, tenacity of life of, Io6.

H. cantiana, on its indigenousness in Britain, 245.

carried with ballast, I97, 245 .

11. caperata, alive in the crop of a

lird, I6I, I63.

amongst larley, 20I, 260. 
11. corthaginicnsis at Cardiff, 253 .

$H$. cartusiana, on its indigenousness in Britain, 246.

IT. cespitum in a bag of nuts, 263 .

H. desertomm, tenacity of life of, IO2.

II. elegans. Sec H. terrestris.

$H$. ericetormm, isolated colony of, 94 . alive in alluvium, $\mathbf{1 4 2}$. near Christiania, 197.

H. fraseri, temacity of life of, Io8.

$H$. fusica, falling with alder leaves, I +7 .

H. hortensis, tenacity of life of, IO7. attempted colonization of, 194.

II. lactea, suspended vitality in, IO4.

production of eggs by, after a dormant period, I04.

Bourguignat on colonization of, 189.

in markets at Bucnos Ayres, 204.

in Britain, 252.

II. laficida, cating into a pollardelm, I 33, I 35 .

possible dispersal of, by currents, I39.

planted in co. Durham, 193.

in New Jersey, 193.

H. lentiginosa, tenacity of life of, I I I.

H. limbata, near London, $25 \mathrm{I}$.

II. nemoralis, in New Jersey, ISo, I 93.

in Virginia, ISO, I93, 200.

H. obvoluta, on its indigenousness in Britain, 247.

II. papilio, tenacity of life of, I Io.

H. paupercula, tenacity of life of, I IO.

II. personata, in Ireland, 257.

H. pisana, tenacity of life of, IoS. colonized near Swansea, I88.

in Guernsey, and put down in Sark, I 89 .

put down at Southport, I90.

in Lancashire, 191.

in Sutherlandshire, I9I.

on its indigenousness in Britain, 246.
II. pomatia, revival of, after submersion in salt-water, 120.

at Bucnos Ayres, 79.

colonization of, I 86 .

British history of, 235 .

H.pulihella, wicle range of, 90 .

$H$. pygmaa amongst leaves, 146.

$H$. rotundata carried by a woodlouse, I 55 .

11. nufescens, shells of, broken before being swallowed by a magpie, I6o.

II. similaris, dispersal of, 136 .

H. strigosa, dispersal of, I 42 .

$H$. tectiformis, tenacity of life of, I IO.

II. terrestris, in Britain, 232, 263.

in South Carolina, 233.

H. turricula, tenacity of life of, I IO.

H. undata, tenacity of life of, Iog.

production of eggs by, after a dormant period, Iog.

$H$. veatchii, tenacity of life of, 108 . H. vermiculata, tenacity of life of, 106.

amongst horehound at Barnsley, $201,255,263$.

11. villosa, in Britain, 193, 253 .

$H$. virgata, possible dispersal of, by wind, I 54 .

carrying a smaller snail, I 55 .

amongst raisins, 263 .

Hemplill, Mr., on dispersal by rivers, 142.

IIcnshall, J., on bivalves clinging to a newt, 77 .

IIeron, probable dispersal by, 50, 52.

a mussel carricd by, So.

Ileynemann, D. F., on a bivalve clinging to a newt, 72 .

to crayfishes, 84 .

Hibernation, has enabled snails to overcome climatic barricrs, 100.

sca-water resisted during, I 20.

clispersal by birds during, 165 .

Higgins, H. I., on dispersal by rivers, I44.

Hoare, $G_{\text {., }}$ on a cockle clinging to a sandpiper, 60. 
Holloway, a Helicina found among orchids in, 199, 263.

Homing, faculty of, I 7 .

Hope, Mr., said to have imported Helix pomatia, 243.

IIorehound, snail in a parcel of, $20 \mathrm{I}$, 255.

Horse-troughs, shells in, 20 .

Iorsley, J. IV., on a mussel clinging by closure, $5 \mathrm{~S}$.

colonization by, 254,263 .

Hot-houses. See Greenhouses.

Howard, C., said to have imported Helix pomatia, 236.

Itudson, B., on living bivalves in the stomachs of frogs, 45 .

on bivalves clinging to frogs, 73.

on Ancy'lus adhering to mussels, 88.

to a frog, $S 9$.

on slugs in kexes, I $7 \mathrm{I}$.

I Iumble-bee, snail clinging to, 85 , I 65 .

Hurricanes, dispersal by, 43, r45, I 46,174 .

Hyalinia cellaria in St. Helena, I 79.

H.drapamaldi in a greenhouse at Preston, 199.

I.

ICE, floating, dispersal by, 4I, I 23. Ingalls, Dr., on an isolated pond, I 7 .

Insects, dispersal by, 47, 6 I, S5, I 54, I 65.

Insular faunas, richness of, increased by time, 123 .

Ireland, whirlwind in, 150.

shower of hay in, 153.

colonization of snails in, rS6.

Helix personata and Bulimus exilis in, $257,25 \mathrm{~S}$.

Islands, land-shells of, often endemic, 90 .

And see Oceanic islands.

Islands, floating. See Floating islanels.
Isoiardiat cor clinging to fish-hooks, 58.

Isolated colonies of land-shells, 94 .

Isolated ponds. See Ponds.

Isolated water, absence of operculate snails from, 86 .

Italy, colonization of molluscs in, I 92.

Helix pomatia said to have been imported from, 236,240 , 243.

\section{J.}

JACKDAW, a snail probably carried by, 165 .

Jamaica, shells in cemented tanks in, 22.

Jeffery, WV., on shells in nonpermanent water, 25 .

on dispersal by floods, 32 .

on bivalves clinging to newts, $7 \mathrm{I}$.

colonization by, IS8, 194 .

Jeffreys, J. G., Dreissena polymorpha carried with water, r 8.

on the diffusion of fresh-water shells, 30.

on Anodonte clinging by closure, 57.

on shells in kexes, I 40.

amongst leaves, 146.

on dispersal by wind, I 54 .

on Helix pisana near Swansen, I 88.

on probable dispersal of Testacella by man, 207.

on Dreissena poly'morpha and Plansubis dilatatus in Britain, 2 I 2,22 I.

on Testacella maugei and Bulimus goodallii in Britain, 229, 230.

on exotic shells found in the British Isles, 227, 252, 253, $256,257,262$.

on doubtfully indigenous species, 209, 240, 246, 247 , 250. 
Jenlins, A. J., on a bivalve clinging to a shrimp, 65 .

to newts, 72 .

on snails adhering to amphibia, 89.

on Physa acuta in Britain, 225. Jeny'ns, L. See Blomefield.

Johnston, G., on long suspended vitality in a snail, IO2.

on Helix pomatia in Britain, $23 \mathrm{~S}$.

Joly, M., on snails reviving after heing frozen, $4 \mathrm{I}$.

\section{K.}

Kent, Helix terrestris in, 232.

Kentish snail. See Helix cantiana. Kew, Physa acuta discovered in the Royal gardens at, 224. on the occurrence of Bulimus goodallii and $B$. decollatus in the gardens, 23I, 26I.

Kexes, dispersal of shells in, I39, I 7 I.

Kindon, Mr., on Helix laclea in Yorkshire, 252.

King, Captain, on tenacity of life in a land-snail, I 2.

Knapp, J. L., on bivalves clinging to newts, 70 .

Kobelt, Dr., on shells passing unhurt through the digestive system of birds, 45 .

on dispersal by herons, 50 .

Helix acuta carried with palmtrunks, 200.

Korschelt, Dr., on dispersal of the fry of Dreissena, 36 .

\section{L.}

Laidlay, Mr., on tenacity of life in Ampullaria, 28.

Lakes, want of continuity of, 98 .

Lancashire, colonization in, I $\$_{5}$, I9I.

Planorbis dilatatus confmed to, 224 .
Land, changes of level of, $2,30,98$, I 7 .

a barrier to fresh-water shells, 3 . Land-shells. See Molluscs.

Layard, E. L., on the Trafalgar Square fountains, 22.

on clispersal by birds, 23,50 .

lizard's eggs found in a crevice of a drifted tree-trunk by, I 3 S.

on clispersal in Wardian cases, I 98 .

on a snail carried to $\mathrm{New}$ Caledonia by the Loyalty Islanders, 203 .

on Helix aspersa at the Cape and in the Loyalty Islands, 204.

Leach, Dr., on Helix pomatia in Britain, 240.

Leaves, dispersal with, I46, I 52, I 54, I 74 .

a shower of, I48, I 53 .

L.cech, clinging to a bird, 50 .

Leeds, an isolated pond near, I4.

Leslie, II. C., on Limnar living in a puddle, 25.

Leucochroa, tenacity of life of, 107.

Lewis, J., molluses colonized by, I 84 .

Liardet, E. A., on dispersal by currents, I34.

Life, tenacity of. See Tenacity of life.

Limax, tenacity of life of, $\mathbf{I} 67$.

introduced into Australasia, I 78 , I 80.

Limax agrestis, in kexes, I 7 I.

in the crop of a bird, I77.

L. flavus, eggs of, in the trunk of a tree, I 73 .

L. levis, in kexes, $17 \mathrm{I}$.

wide range of, 173 .

in Australia, I73, I78.

L. maximus, living under the bark of trees, I69.

eating into decaying wood, I 70. in Tasmania, $20 \%$.

Limner, in isolated waters, 6 ef ser.

voluntary migration of, 4,26 .

adhering to pond-weed, 53 . 
Limnac auricularia, eggs of, passing the digestive system of swans, 46 .

on dried eggs of, 47 .

L. humilis in an artificial pond, I6. in non-permanent water, 25.

L. macrostoma in an isolated pond, I 7 .

L. parta, in a horse-trough, 20.

in non-permanent water, 25.

L. peregra in a water-trough, 20.

in the Trafalgar Square fountains, 22.

in puddles, 25.

wandering on land, 26.

dispersal of, while floating, 35. reviving after being frozen, 42.

adhering to turtles, $S S$.

to a toad, 89 .

I. reflexa, dispersal of, by floods, 32 .

I. stagnalis reviving after being frozen, 42.

in New Zealand, IS4.

in Tasmania, 195 .

L. truncatula migrating over land, $4,26$.

on the tower of a church, 5 . I 65.

in horse-troughs, 2 I.

in non-permanent water, 24,25 . diffusion of, in Madeira, 25.

tenacity of life of, 27.

dispersal of, during floods, 32 .

Limpet. See Ancylus.

Lincolnshire wolds, isolated ponds of, 9 .

Lindsay, J., Helix olvoluta discovered in Britain by, 247.

Lister, on Helix pomatia in Mritain, $235,236,238$.

lithoglyphus naticoiles in Britain, 226.

Liverpool, Bulimus undalus near, 202, 259 .

Lizard's eggs found in crevice of drifi-wood, I3S.

Local distribution. See Distribution.

London, Dreissena polymorplat in streets of, 1 S.

Helix limbata near, 25 I.
Long, F. C., on Planorlis dilalalus at Burnley, 223.

Lord, J. K., on an otter's shell clinging to a shoveller-duck, 60 .

Louth, an isolated pond near, 9, ro.

Loyalty Islanders, snail trans. planted by the, 203 .

Loyalty Islands, Helix aspersa in, 205.

Lukis, Dr., attempt to colonize Helix pomatia in Guernsey, I 87.

on the supposed occurrence of Helix aperla in Guernsey, 256.

Lukis, Mr., colonization of Helix pisana in Guernsey, 189.

Intraria, shoveller-duck caught by, 60.

Lyell, Sir C., on an introduced Limmea in Madeira, 25, ISI.

on the dispersal of shells and their eggs, 29, 36 .

on dispersal by whirlwinds and hurricanes, 42, I 45, I 49, I 52, 153.

on an Aucylus adhering to a Dytiscus, 87 .

on the shells of Madeira and Porto Santo, 96.

on tenacity of life in a Bulimms, I 2 .

on the scarcity of evidence as to the means of dispersal of land-shells, I 19.

on dispersal by icebergs, 123 .

by pumice, 124 .

by birds, I 57, I 59 .

on floating islands, I 29, I 36 , 174.

on snails carried in flower-pots, 200.

on Bulimus mudatus near Liverpool, 202, 259 .

on the dispersal of Dreissend polymorpha, 2 I 1 .

M.

McDakis, Mis., Melix terrestris discovered in Kent by, 232. 
Macgillivray, J., on shells in waterpipes, 19.

McLachlan, R., on caddis-larve attaching living shells to their cases, 35 .

McNurtrie, J., colonization by, 192.

McNabb, D., on a cockle clinging to a sandpiper, 60.

Macpherson, H. A., on clispersal by birds, 50 .

Madeira, possesses many endemic land-shells, 9I.

shells from Porto Santo have not established themselves in, 96.

introduced molluscs in, 97, I79, I S I, I 99, 200.

tenacity of life in snails of, Iog.

Magpie killing snails beforeswallowing them, I 60 .

Mallard. See Duck.

Mammalia, dispersal by, 5o, 155 .

Man, dispersal by, 23, 96, I 56, 173 , I 78, 209.

extermination by, ISI.

shells introduced into the British Isles by, 209.

Man-of-war, French, clispersal of "escargots" by, 205, 206.

Manchester, Dreissena polymorpha in water-pipes of, I8.

shells in artificial lakes near, I9.

colonization near, I 85 .

Hyalinia drapamaldi in a fernery near, I99.

Planortis dilatatus discovered near, 221.

Bulimus octomus found in greenhouses near, $26 \mathrm{I}$.

Manchester Museum, specimens illustrating means of dis. persal exhibited in, 62, 64, 65,71 .

Margaritana margaritifera, in Island of Anticosti, I8.

Marine bivalves clinging to other animals by closure of the valves, 58 .

Marine currents. See Currents.

Marsh-slug. See Limax levis.
Marsh, IV. A., on shells in a horsetrough, 20.

in non-permanent water, 24.

on dispersal by floods, 32.

Marshes, dry in summer, sliells in, 23.

Martello-towers near Eastbourne, smails in disused gardens of, I9S.

Martin, $\mathrm{Mr}$., on dispersal of Limnar while floating, 36 .

Maryland, whirlwind in, 149.

Mason, J. E., on isolated ponds, I I, 12 .

Mason, P. B., on Bulimus detritus at Burton-on-Trent, 259.

Maton and Rackett, on Helix pomatia in Britain, 237.

Medicinal purposes, dispersal of molluses for, 203, 235, 243.

Mendes da Costa. See Da Costa, E. M.

Merret, on Helix pomalia in Britain, 235.

Migration, voluntary, 4, 26, I16, I 44.

Miller, J. S., on Testacella mangei and Bulimus soodallii in Britain, 228, 230.

Miller and S'weet's nurseries, T'estacella maugei and Bulimus soodallii in, $22 S, 230$.

Miocene land-shells, I 5 .

Mississippi, rafts of, I 29.

Mohawl River, molluses colonized in, 184 .

Molge. Sce Newts.

Molluscs, rapid increase of intro. duced species, 25, 179 .

reasons for the differences in the distribution of fresh-water and land kinds, 95.

European species widely dispersed by man, i 78 .

colonization of, by man, $\mathbf{I} 82$.

Molluscs, fresh-water, wide distribution of, 4 .

tenacity of life of, $24,27$.

means of dispersal of, 27.

dispersal of floating kinds, 35 .

in brackish water, 39 . 
alive after being frozen, $4 \mathrm{I}$.

experiment with sea-water and Neritina, $4 \mathrm{I}$.

a shower of, 44.

dispersal of livalies while clinging to other animals by closure of their valves, 56 .

of mivalves while clinging by closure of the operculum, 85 .

while clinging by adhesion, 86 . their absence from some oceanic islands, 93.

want of continnity of habitats of, 99 .

Molluscs, land, specific areas sometimes wide but generally restricted, 90.

kinds found in islands often endemic, $9 \mathrm{I}$.

some genera range widely, 92. dispersal of, 95, I 5 .

tenacity of life of, 99, I20, 167 . antiquity' of, I I 5 .

sea-water resisted by, I 20.

habitats of, conducive to dispersal, I32, I40, I46, I69, I 71,173 .

small species, and operculate species, range more widely than large inoperculate kinds, 136 .

the floating or sinking of, when thrown into water, 140, I 70.

their occurrence in alluvium, I 4 I.

found alive in the crop of a bird, $16 \mathrm{I}$.

dispersal of operculates, 165 . of slugs, 167 .

Noluccas, floating islands amongr the, I3I.

Moniz, J. MI., snail carried to Madcira, 199.

Monophyletic descent, I.

Montagu, on Helix pomatia in Britain, 237.

Montevideo, pumas landed at, I 30 . snails from, living in Yorkshire, 192, 202.

Moor-lien, probable dispersal ly, 52.
Mörch, Dr., on Drcissena foly' morpha, 2 I4.

Morrison, J. H., Helix nemoralis in Virginia, I $80,200$.

Morton, J., on colonization of Hclix fomatia, I 87 .

Noseley, II. N., on floating timber, I26, 135 .

Moss, a Helix found in a consignment of, 199.

Mountain torrent, dispersal by, 34 .

Mouse, oyster closing upon, $5 \mathrm{~S}$.

Mussel closing upon the tongue of a fox, 58 .

upon the foot of a tern, 60 .

upon the bill of a crow, 60 .

Mussels, fresh-water. See Anodonta and Unio.

Musson, C. T., on voluntary migration by a Limnea, 4 .

on bivalves in isolated ponds, 9 . on shells in an iron tank, 19.

in a water-butt, 20.

on dispersal by floods, $3 \mathbf{I}$.

on a ball of earth on the leg of a bird, 54 .

on the flying labits of water. beetles, 66 .

on tenacity of life in a land. snail, ro3.

on a drifted canoc, 128.

on Succinea arliorea living under bark, 132.

on Helix aspersa living in cut bamboos, 140.

on dispersal by wind, 148 .

on dust-whirlwinds, I49.

on a beetle and a woodlouse carrying snails, 155 .

on a Helix carrying a smaller snail, 155.

on foreign snails in an orchid. house, 198 .

on transportal of snails at the roots of ferns, 200.

on Helix pomatio in Britain, 240.

N.

Nature can afford to wait, 164. 
Neill, Pat., colonization of Itelix pomatia by, IS7.

Nelson, T. H., shells not seen upon birds' feet by, 50.

Nelson, IV., on additions to the fauna of a pond, I4.

Nepa, bivalves clinging to, 62 .

carrying powers of, 69.

Neritina, wide dispersal of, 40.

experiments with, in salt water, $4 \mathrm{I}$.

egg-capsules of, $4 \mathrm{I}$.

Nests, probable dispersal by birds when building, I64.

New Caledonia, snail carried to, by Loyalty Islanders, 203.

New Jersey, Helix nemoralis and H. appressa colonized in, ISo, I 93.

New Zealand, colonization in, I $S_{4}$.

Newcastle, Parmacella found near, $20 S, 263$.

Newcomb, H. L., on a Unio clinging to a teal, So.

Newman, E., on shells in waterpipes, 19.

Newton, Professor, on earth on the leg of a partridge, $15^{8}$.

Newts, shells extruded by, 46 .

bivalves clinging to, 70,76 .

wandering habits of, 75 .

carrying bivalves over land, 77. snails adhering to, 89 .

Nicholls, Dr., on drift timber, I28, 135.

on transportal of shells with plants, I 96.

Norgate, F., on a leech clinging to a bird, 50 .

on probable dispersal by herons, 52.

on a rail caught by an oyster, 60.

on bivalves clinging to waterbeetles and newts, 64,72 .

on the flying habits of waterbeetles, 66 .

on the wandering habits of newts, 75 .

Norman, A. M., on Dreissena polymorpha in water-pipes, I 8 .

on Physa acula, 225.

Norman, G., on foreign snails colonized in Yorkshire, 193.

on transportal with cattle-bone, 202.

Northamptonshire, attempt to colonize Helix ponatic in, I87.

Norway, colonization in, IS4, I $S_{7}$.

Notonecta, bivalves clinging to, 62 , 63.

carrying powers of, 69 .

Nottingham, foreign smails in an orchid-house at, $199,263$.

Nova Scotia, land-shells of coal. measures of, I I 5 .

Nuts, shell in a bag of, 263 .

\section{O.}

OAK-LEAVES, shower of, I4S, I 53.

Ocean currents. See Currents.

Oceanic islands, endemic land-shells in, 90 et seq., I 23 .

almost all inhabited by landshells, 92.

on the stocking of, 92, I64, I 72, I 76 .

fresh-water shells sometimes absent from, 93.

arrival of species not witnessed, I I 9 .

richness of faunas of, increased by time, 123 .

Oceans, general permanence of, I, I 7 .

changes in, 2, I 8 .

Oldham, C., on a bivalve clinging to a water-beetle, $6_{4}$.

on the carrying powers of water-beetles, 68 .

Operculate snails, dispersal of, $\mathrm{S}_{5}$, I 65.

absence of, from isolated waters. 86.

tenacity of life of, I I 3 .

distribution of, 136 .

Operculum, molluses clinging by closure of, 85 . 
Orchid-houses, foreign snails in, $199,231,263$.

Orchids, a Helicina found in a case of, I 99.

Orcutt, C. K., nn shells in a tauk, 21 .

Orinoco, rafts of, I 29.

drift-timber from, at Tobagn, I $2 S, 135$.

Otter's-shell, shoveller-duck caught by, 60 .

Otters, probable dispersal by, 50.

Ova. See Eggs.

Owls, probable dispersal by means of, 162.

Oxford, Helix pomatia in Botanic Garclens at, I $\$ 6$.

Oxford Street, Dreissence poly"morphe in water-pipes in, IS.

Oysters, mice, rat, and fox caught by, 5 .

rails, plover, and cormorant caught by, 6o, 6 I.

P.

PAI,A:OZOIC coal measures, land. shells of, I I 5 .

Palm-trunks, shells carried on, 200.

Paludina vivitara, tenacity of life of, $2 S$.

clinging by closure of operculum, 86.

Parana, rafts of, I 30 .

I'armacella found near Nerrcastle, $208,263$.

Partridges, earth on feet of, $15 S$.

Parus biarmicus, shells in crop of, 160.

Pascal, L.., on a snail's eggs passing the digestive system of swans, 46.

Payne-Gallwey, Sir R., on a cockle clinging to a dunlin, 59.

Peacock. See Woodruffe.Peacock.

l'earce, S. S., on a bivalve clinging to a frog, 73 .

on dispersal with chalk, 197.

with soil, IgS.
Pearl-mussel. See Unio margaritifer.

Peers, J., on bivalves clinging to toads, 74 .

Peewit, cockle clinging to, 59 .

Penmant, on Hclix pomatiet in Britain, 235.

Peregrines, probable dispersal by means of, I6I-2.

Petersfield, attempt to colonize Helix pomatic at, is 87 .

Pfeiffer, Madame Ida, tenacity of life in Cyclostoma, I 13.

Pheasant, slugs in crop of, 177 .

Philippines, floating timber amidst, I 3 I.

land-shells of, 136 .

Phy'sa, in tanks, I9, $2 \mathrm{I}, 22$.

Physe acute, in Britain, 224.

$P$. gibbose, in a tank, 19.

$P$. syrina, carried with plants, 196.

Piclicring, Mr., on tenacity of life in land-snails, ro9, I I 3 .

Pidgeon, D., on heart - cockles clinging to fish-hooks, $5 \mathrm{~S}$.

on Helix pomatia, 24 I.

Pigeon, balls of earth on legs of, 54, I 58.

living snails in the crop of, I6I, I 63 .

barley scattered from the crop of, 162.

Pinc-beds, Bulimus goodallii in, 230.

Pine-plants, supposed dispersal with, 230.

Pisidium, on land, 4, 34.

killed by frost, 42 .

in stomachs of frogs, 45 .

extruded by newts, 46 .

clinging to water-beetles, 65 .

to a newt, 72 .

Pisidium or Spharium, clinging to crayfishes, $8_{3}$.

Pisilium etheridgei, clinging to water-bugs, 63 .

$P$. fontinale clinging to $N_{e} p a, 62$.

to a water-beetle, 65 .

Plunorlis, adhering to cullecting nets, 16.

reviving after leeing frozen, 42 . 
adhering to pond-weed, 53 .

tenacity of life of, 221.

Planorbis dilatatus in England, 209, $22 \mathrm{I}$.

found in a cistern, 20, 224.

$P$. slabie, specimens of, perliaps introduced into England, 2 I O.

P. nautileus amongst floating weed, 34.

Plants, clispersal with, 34, 51, I33, I 39, I 70-I, I 82 , I 95, I 9 , $201,207 \cdot 8,224,226,228$, $23 \mathrm{I}, 247,250,252,254 \cdot 5$, $257,260-2$.

Pleurocera, dispersal of by floods, 33.

Pliocene land-shells, I I 5 .

Plover caught by an oyster, $6 r$.

Polyphyletic descent, 3 .

Pond-weed, shells adhering to, 34, 53.

Ponds, shells in, after being long dry, 25.

Ponds, isolated, 5 et seq.

additions to the famna of an isolated pond near Leeds, I4. probably stocked by waterbeetles, 69 .

and birds, 82 .

absenee of opereulate smails from, 86.

Porto Santo, its land-shcll-fauna not common to Madeira, 9I.

shells from, probably carried to Madeira with stone, have not established themselves, 96.

European shells in, 97.

tenaeity of life of snails of, I09, II I.

Portuguese, introduction of a $\mathrm{Lim}$ naca into Madeira by the, 25, I8I.

dispersal of land-shells by the, $200,203$.

Poulton, E. B., on tenacity of life in Testacella, I68.

Preston, pond-snail on the tower of a church at, 5, I65.

Hyalinia drapamaldi in a greenhouse at, 199.
Puddles, shells in, 23, 25.

Pulteney, on Helix pomalia in Britain, 237.

I'umas, landed by means of floating rafts, 130 .

l'umice, floating, probable dispersal by, I24, I 39, I 74 .

$P u p a$, wide range of, 92 .

in Palcozoic coal measures of Nova Scotia, I 5 .

Pupa cinerea, in Britain, 234.

P. muscontm in the crop of a bird, 160.

$P$. tridens, tenacity of life of, I 13 .

P. umbulicata carried by a larger snail, I 55.

Q.

QCERRCEDE'LA DISCORS, mussel carried by, 8 o.

R.

Racoons entrapped by livalves, Rac, IV. D., on Physa acuta in Scotland, 226.

Rafts. See Floating Islands.

Rails eaught by oysters, 60 .

Railway ballast, dispersal with, I97, 252.

Raisins, shell amongst, 263 .

Rat, oyster closing upon the tail of, 58.

mussel closing upon the foot of, 83.

earrying snails, I 55 .

Redcar, colonization at, i $\$ 6$.

Redding, Sir R., mussels clinging by closure, 57 .

Redshank, bivalve elinging to, 79 .

Redwings, probable dispersal by, 165 .

Recve, L., on "facilities of migration," 86, 95.

on multiple spccific centres, II 8 .

on Dreisscna polymorpha and 
INDEX.

Helix pomatic in Britain, $213,241$.

Reirl, C., on isolated ponds, 6.

on shells in horse-troughs, $2 \mathrm{I}$.

on the Trafalgar Square fountains, 23 .

on transportal of plants and shells by birds, 52 .

on shells adhering to plants, 53.

on birds ejecting the contents of their crops, 163 .

on Helix obroluta, 249.

Reservoirs, shells in, IS.

Rhaphaulus, tenacity of life of, I I4. Rhode Island, snail from Cliba found in, $20 \mathrm{I}$.

Rich, Mr., Clausilia solida found near Bristol, 262.

Riches, J. T., on a bivalve clinging to a frog, 72.

Rigsby, an isolated pond at, 12.

Rimmer, R., on establishment of Helix pisana near Swansea, I 88 .

on its indigenousness in Britain, 246.

on the indigenousness of Testacella haliotidea in Britain, 250.

on the occurrence of Clausilia solida near Bristol, 262.

Riplingham, an isolated pond at, Jo.

Rivers, want of continuity of, $9 S$.

trees and pumice stranded o the banlis of, 139 .

And see Currents.

Roberts, G., on dispersal of Limnere while floating, 35.

on living snails in a bird's crop, I6I, 163 .

on a thrush dropping a snail, 165.

Robertson, Mrs. D., Helix villosa discovered near Cardiff by, 253.

Robson, C., on newts extruding shells, 46 .

Roebuck, W. D., on shells in a water-trough, 20. on Limnace in puddles, 25.

Rogers, 'T', attempted colonization of Helix pisana by, I9I.

Planorbis dilatatus discovered in Britain by, $22 \mathrm{I}$.

Roman suail. See Helix pomatia.

Romans, Helix pomatia said to have been carried to Britain by the, 240.

Rossmässler, Professor, on Dreissena polymorpha attaching itself to crayfishes, $8_{4}$.

Royal Gardens. See Kew.

S.

SAHARA, a smail's eggs found upon the foot of a bird shot in the, 47.

Sailors, dispersal by, 203, 259.

St. Helena, its isolation, 93.

its land-shells, 93, 94.

absence of fresh-water shells from, 93 .

introduced molluses in, I79, I 82 .

extermination of native species in, I8I.

Salt-water, injurious effects of contact with, 39, 4I, I20, I 2 I, I 34, I 72 .

revival of snails after submersion in, 4I, I 20, I34.

seeds and shells in birds' crops protected from, ${ }_{6} 63$.

Salter, J. 11., on IIelix lactea in Yorkshire, 253.

Sanderling, cockle clinging to, 60.

Sandpipers, cockles clinging to, 60.

fresl-water mussels clinging to, 79.

Sandwich Islands, sliells of, 91, 94 , 96.

restricted specific areas in, 9I, 96.

isolated position of, 94 . 
Sanger, E. B., on shells in flood. water, 33 .

Sankey, R. H., on tenacity of life in Rhaphaulus, II4.

Sark, attempted colonization in, I 89 .

Saunders, H., shells not seen upon the feet of birds by, 50 .

Scarborough, colonization of Helix pomatia near, I 86.

Schäff, Mr., bivalve clinging to a redshank, 79 .

Scharff, R. F., on shells in alluvium, I 4 I, I 42 .

on the dispersal of slugs, 172 , I75.

eggs of a slug found in a treetrunk by, 173 .

on Testacella mangei in Britain, 229.

Scotland, shower of leaves in, 148 , I 53 .

attempted colonization of IIelix pomatia in, I87.

Dreissena polymorpha in, 216.

Phy'sa acuta in, 226.

Clausilia papillaris in, $26 \mathrm{I}$.

Scouler, J., on Dreissena polymorpha in Scotland, 216.

Sea, fresh-water organisms derived from the, 3 .

Sea-water. See Salt-water.

Semper, K., on polyphyletic descent, 3 .

on the distribution of Trocko. morpha, 90 .

on dispersal by ocean currents, I 20,136 .

Sharp, D., on the carrying powers of water-beetles, 67 .

Sheep, probable dispersal by, $\mathbf{I} 2$.

Shell-collectors, probable dispersal by, $13,16,258$.

And see Colonization.

Shells. See Molluscs.

Ships, snails carried by, as "live sea stock," 203.

Ships' ballast, dispersal with, 196, $245-7,252-4$.

Shops, foreign snails found in, 20I, 255,263 .
Shoveller-duck, caught by au otter's shell, 60.

Showers of fish, 43 .

of frogs, 43,44 .

of water-beetles, 44 .

of fresh-water mussels, 44.

of leaves, 148 .

of hay, 153 .

of snails, I 54 .

Simpson, C. T., on dispersal by floods, 33 .

on dispersal of fresh-water shells by marine currents, 37 . on drift-wood, 127, 134 .

on dispersal of large tree-snails, 137.

Simroth, Dr., on dispersal of Testacellie, I 7 I.

Skuas cause other birds to eject the contents of their crops, 163.

Slugs, dispersal of, $167,207$.

cannot bear long exposure, I67, I 75 .

tenacity of life of, 167 .

wide ranges of, 172 .

allow themselves to drop from small objects, I 74 .

introduced species in Australasia, I 7 S, I80.

supposed destruction of snailcolonies by, 194.

Smith, E. A., on the egg-capsules of Neritina, 4I.

on extermination of native species in St. Helena, 94, I 82.

on Helix terrestris in Britain, 232.

Smyth, W. II., on floating timber, I 3 I.

Snails. See Molluscs.

Snapping-turtle, a mussel carried by, 83.

Snipe, earth adhering to, 54 .

cockle clinging to, 60 .

Spharium clinging to, $8 \mathrm{I}$.

Soil. See Earth.

South Downs, isolated ponds of, 6 .

Southport, Helix pisana planted at, I 90. 
Sowerby, G. B., Helix limbata found near London by, $25 \mathrm{I}$.

Sowerby, G. B. (grandson), on Helix limbata, 252.

Sowerby, J. Dc C., on Dreissena polymorpha and Testacella maugei in Britain, $210,228$.

Sowerby, IV., on Phy'sa acuta in the Royal Botanic Society's Gardcns, 226.

Sparrows, suggested dispersal by, 23.

Species, closcly-allied, cannot estab. lish themselves in cach other's tcrritories, 96.

Sphaium or Pisidium, clinging to crayfishes, $8_{j}$.

Spharium corneum, clinging to the larva of a dragon-fly, 6I.

to Nepa, 62 .

to Dytiscus, 63 et seq.

to $n \mathrm{cw}$ is, $70,76,77$.

to frogs, 72,76 .

to toads, 74 .

carried over land by watcrbectles, 68 .

by a newt, 77 .

by a snipc, SI.

S. lacustre, in a new isolated pond, 12.

clinging to a water-bcetle, 65 .

S. ovale, its indigenousness in Britain, 209.

Sphasmum, a Helix found in a consignment of, 199.

spiccr, J. W. G., slugs found in the crop of a bird by, 177.

Spix and Martius, on the drift-wood of the Amazons, I 29.

Springall, C., a crow caught by a mussel, 60 .

Standen, R., on shells in brick-pits, 17 .

in artificial lakes, 19.

on a smail's eggs attached to a water-bectle, 47 .

on plants and earth adlering to bircls, 52, 54 .

on Pisidiun clinging to Nefa, 62. on Spharium clinging to watcrbcctles, 64, 65 .

on the flying habits of watcrbcctles, 66.

bcetles carrying shclls caught on the wing by, 68, 87 .

on bivalves clinging to newts, $7 \mathrm{I}$.

to frogs, 73,76 .

to toads, 75 .

on a mussel clinging to a duck, 79 .

to a heron, So.

on an Ancylus adhering to a water-beetle, 87 .

on a Limnea adhering to a toad, 89.

on isolated colonies of landshclls, 94 .

Hyalinia draparnaldi found in a fernery ncar Manchester by, 199.

Stark, Mr., on Dreissena poly. Inorpha in Scotland, 216.

Stearns, R. E. C., on tenacity of life in a land-snail, I I I.

on dispersal with dye-woods, 202.

Stettin, colonization near, 193.

Stewart, S. A., on the Irish specimen of Helix personata, 257 .

Stonc, probable dispersal with, 96. Streams. See Currents.

Strickland, H. E., on Dreissena polymorpha in Britain, 2I3, 215,216 .

Stuchbary, Mr., Dreissena polymorpha planted at Bristol by, I 83 .

Succinca, rcviving after being frozcn, $4 \mathrm{I}$.

found in a bird's crop, I6o.

cggs (probably of a) found upon the foot of a bird shot on the wing, 47 , 157.

Sucinea arlorea, living under bark, 132.

S. putris carricd by floods, $\mathrm{I}_{42}$.

its ova probably carried by birds, I 57. 
Sutlerlandshire, colonization in, I $\$ 5,191,195,262$.

Swamps, shells in, 23.

$S$ wans, eggs of a snail passing the digestive system of, 46 .

Swansea, Helix pisana colonized near, isS.

Swaysland, Mr., on earth on the feet of birds, I 59.

T.

TANKS, shells in, I9, 2I, 22.

Tasmania, Limnace stagnalis in, I 95.

Limax maximus in, 207.

Tatc R., on dispersal by streams and floods, 3 .

on dispersal of eggs of freshwater shells, 46 .

on mussels clinging by closure, 57 .

on snails carried by ships as live sea stock, 203.

on Dreissena polymorpha and Helix cantiana, 2 I 3, 245.

Taylor, J. W., on an isolated pond, I 4 .

species determined by, I 4, 234 .

Taylor and Roebuek's census of the distribution of British land and fresh-water shells, 219.

Teal, mussel carried by, So.

Tcator, IV.C., on Anorlonta in a hole formed by peat-cligging, I $S$.

'Tegetmeicr, IV. B., on earth on the feet of a partriclge, I 58 .

Tenacity of life of fresh-water shells, $24,27,4 \mathrm{I}, 49,2 \mathrm{II}, 22 \mathrm{I}$.

of land-shells, 99, I 20.

of slugs, 167 .

Terns, cockle and mussel clinging to, 59, 6o.

Testacella, temacity of life of, I67. coeoons formed by, I68.

dispersal of, I69, I7I, I94, 207.

Testacella haliotidea, 250.
T. mansci, $22 \mathrm{~S}$.

its nest of carth, I6S.

T. scutulum, 250.

'Thames, shells carried by floods in, $3 \mathrm{I}$.

discovery of Dreissena poly. morpha in, 2I I, 2 I 5 .

Thomas, A. P., on tenacity of life in a pond-snail, 27.

on dispersal by floods, 32 .

Thompson, IV., on pond-snails adhering to turtles, SS.

on snails planted in Ireland, I $\$ 6$.

Thomson, J. II., attempted colonization by, 194.

Thrush, snail carried and dropped by, 165 .

probable destruction of colonies by, 190.

Timber, dispersal with, 200, 20I, 2 I I , 259.

Timber, floating, dispersal with, 33 , 35, 37, 4I, I22, I 26 el seq., I 39, I69-7I, I 74, 2I 5, 220.

seen on the ocean, 126-7, I 29 , I 3 I.

often floats under the surface, I 35 .

bark often lost in the sea, 135 . drift-timber, stranded on coasts, I $27-8$, I $34-5$.

on a river-bank, I 39 .

eggs of a lizard found in a crevice of, 138 .

'Time, richncss of faunas inereascd by, 123.

Nature can afford to wait, 164 . 'Titmouse, shells found in the crop of, 160 .

Toad, livalves clinging to, 74 . climbing powcrs of, 76 . snail carried by, 89 .

'Tudd, J. E., on a turtle carrying a mussel, $\delta_{3}$.

'Tormadoes, 149.

Totanus, bivalves clinging to, 79 .

Tothby, isolated pond at, I I.

Trafalgar Squarc fountains, shells in, 22.

Tree-snails, dispersal of, 136 . 
Trees, molluscs living under the bark and in hollows of, 132, I69, 173 .

eating into the wood of, 133 , I 70 .

And see Timber.

Trent Valley, Mr. Musson on the abundance of shells in, $3 \mathrm{I}$.

Tristram, H. 13., snail's eggs found on the foot of a bird by, 47, I 57 .

on colonization in co. Durham, I $93,254$.

Trochomorpha, distribution of, 90.

'Troughs, shells in, 20.

Trout, a Limnea transplanted as food for, $\mathrm{IS}_{4}$.

Turtle, mussel carried by, $\$_{3}$. pond-snails adhering to, SS.

Turton, Dr., on shells amongst leaves, 146.

on Bulimus goodallii, B. decollatus and Helix pomatia in Britain, $230,23 S, 260$.

Tweedie, F, on the finding of a bird's claw between the valves of a mussel, 77 .

Tye, G. S., on Dreissena polymorpha in water-pipes, 19.

on Helix pisana in Guernsey, I 90.

Typhoons, I3I, I 49.

U.

UMBelliferous plants, molluscs in the kexes of, I39. I7I.

Unio or Anodonta, clinging to a sandpiper, 79.

to a heron, So.

to a duck, So.

Unio, tenacity of life of, $2 S$.

living among tree-roots, 37 .

dispersal of fry of, 48 .

clinging by closure, $57,5 \mathrm{~S}$.

ducklings caught by, 77 .

Unio complanatus carried by a teal, So.

by a turtle, $S_{3}$.
U. margaritifer, dragged to shore upon rods, $57,5 \mathrm{~S}$.

Ancylus adhering to, SS.

Unionide, dispersal of, by floods, 33 .

dispersal of fry of, $4 \mathrm{~S}$

United States, snails imported into, as articles of food, 203.

United States National Museum, slug found in a bunch of bananas received by, 207 .

Univalves, dispersal of, while clinging by clostire of the operculum, 85,165 .

And see MIolluscs.

Upton, attempted colonization of Helix hortensis at, 194.

\section{V.}

VERNÈDI, Mr., on tenacity of life in the desert-snail, IO3.

Veronicella, found among bananas, 207.

Vertigo edentula, in kexes, I 40.

amongst leaves, 147.

$V$. milizm, weight of, I47.

$V$. pygmaa, colonies of, 94 .

Victoria, dust whirlwinds of, I 49.

introduced slugs in, I So.

Virginia, Helix nemoralis in, ISo, I93.

Vitality, suspended. See Tenacity of life.

Vitrina (Helicarion) carried by a beetle, 155 .

Vole, trapped by a mussel, $\delta_{3}$.

Voluntary migration, 4, 26, II 6 , I 44 .

IV.

Wagtails, earth on the feet of, I 59.

Walken, J., Nepa with a bivalve attached caught by, 62 .

Wallace, A. R., on the general permanence of oceans, I, IIS. 
on changes of level, 30.

on salt-water killing snails, 40.

on dispersal of eggrs of fresh-

water shells, 46.

on dispersal by water-beetles, 67.

on the stocking of oceanic islands, 92, 164 .

on the antiquity of land-shells,

I I 5 .

on voluntary migration, I I 6.

on hypothetical continents, I I 8 .

on the want of evidence of

exact modes of diffusion, I 18 .

on dispersal by rivers and

floods, $13 \mathrm{~S}$.

by wind, I 45, I 52 .

by lirds, 159 .

Vard, James, on tenacity of life in a snail, 107 .

Ward, John, living shells found in a bird's crop by, I6 I, I63.

Vardian cases, dispersal in, I98, 207.

Warren, Miss, on dispersal by cattle, 156.

on Bulimus exilis in Ireland, 258.

Warren, R., on a cockle clinging to a dunlin, 59 .

TVars, dispersal during, 203.

Water, dispersal with. See Currents. isolated. See Ponds.

Water-beetles. See Beetles.

Vater-bugs. See Corixa, Nepa, and Notonecta.

Water-butt, shells in, 20.

Water-pipes, shells in, $\mathbf{I}$.

Vater-rails caught by oysters, 60 .

VVater-scorpion. See Nepa.

Water-vole trapped by a mussel, 83.

Watson, R. B., on introduced molluses in Madeira, I79.

IVatson, IV., on Physa acuta at Kew, 225.

Webb, C. J., whirlwind described by, 150 .

Weir, J.J., on tenacity of life in the desert snail, IO4.

IVells, Artesian, 22.
Welton-le-Wold, isolated pond at, 9. 10.

Westgate, IV. IV., on dispersal with plants, 195 .

Wheatears, earth on feet of, 159.

Whincliats, earth on feet of, 159.

Whirlwinds, 42, 149, I 74.

White slug. See Limax agrestis.

Whitelegrge, Mr., bivalves clinging to water-bugs, $6_{3}$.

to water-beetles, 65 .

Widgeon, probable dispersal by, 50 .

Vildman, J. R., on Planorbis dilatatus at Burnley, 224.

Wilson, G. F., on Bulimus soodallii, 231.

Wind, dispersal by, 42, I 45, 174 .

IVolds, isolated ponds of, in Lincoln. shire, 9.

in Yorkshire, $\mathbf{I O}$

Wollaston, T. V., on the absence of fresh-water shells from St. Helena and the Azores, 93.

on tenacity of life in snails, IOg.

Wood, dispersal with. See Timber.

Woodcock, cake of earth on the leg of, 54,158 .

Woodlouse, a snail carried by, 155 .

IVood-pigeon. See Pigeon.

Woodruffe-Peacock, E. A., on mussels clinging by closure, 57.

Woodthorpe, E., shells collected from an isolated pond by, 12.

frogs with shells attached observed lsy, 74 .

Woodward, S. P., on isolated colonies of land-shells, 95 .

on tenacity of life, I05, I06, I 13 .

on dispersal by sailors, 203 .

on Dreissena polymorpha and Testacella maugei in Britain, $213,229$.

IVorms, living, ejected from the crops of birds, 164 .

Wotton, F. IV., on Bulimus goodallii, $23 \mathrm{I}$.

on Helix carthaginiensis, 253. 


\section{INDEX.}

on Helix villosa and $H$. carlusiana, 254 .

Wright, B. M., dormant snails revived by, 103 .

\section{Y.}

YORKSHIRE, isolated ponds on the wolds of, Io.

foreign snails living in a garden in, $192,263$.
Helix lactea found in, 252. loung molluscs. See Fry.

Z.

Z.ANYCHELLIA, shells adhering to, 53 . Zebra mussel. See Dreissena polymorpha.

Zonites in Palrozoic coal measures of Nova Scotia, I I5. 



\title{
C LASSIFIED LIST
}

OF

\section{THE PUBLICATIONS OF}

Kegan Paul, Trench, Trübner,

\author{
and Co. Limited
}

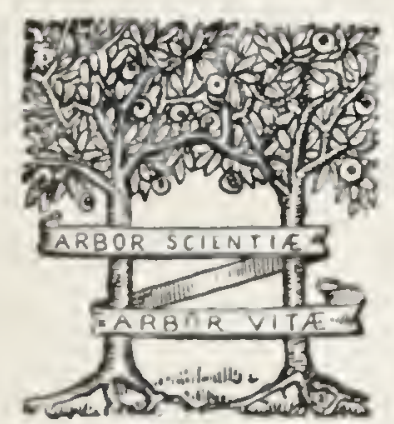

L O N D ON

IEGAN PALL, TKENCH, TRÜBNER \& CO, LTD.

Pateknoster HOUSe, Charing Cross Road 



\section{CONTENTS}

Works on Oriental Subjects :-

PAGR

Relating to India, etc. $\quad$. $\quad$. $\quad$. 5

On Oriental Buddhism . $\quad$. $\quad$. $\quad$. 9

Relating to China . . . . . . II

Relating to Islam . . . . . . I2

Persian Religion and Literature . . . . . I2

Relating to Japan . $\quad . \quad$. $\quad . \quad$. $\quad$. 13

Jewish History and Religion . . . . . 13

Archæology of Egypt and Assyria . • . . I3

Worzs on Comparative Philology, The Science of Language, Grammars, Lexicons, Etc. . . . . . I4

Works on Theology, Biblical Exegesis, and Devotional

SUBjECTS . . . . . . . . 22

Works on Speculative Theology, Philosuphy, and Com-

PaRATIVE Religion . . . . • . 29

MYTHOLOGY AND FOLK-LORE . . . . . 33

Works relating to the Occult Sciences, Animal Magnet.

ism, Spiritism, AND Theosophy • • • . 35

Numismatics . $\quad$ - . . . . . 37

Generai and European History • • . . 38

Travels, Voyagr, and Goide-Books . . . 40

BIOGRAPHY • • • . • . . 42

WORKS ON EDUCATION . . . . . . 47

Greek and latin Classics, Etc, . . . . 48 
WORXS ON MIITARY SCIENCER

WORKS ON MILITARY SCIENCE . . . . 48

Botany and Natural History . . . . . 50

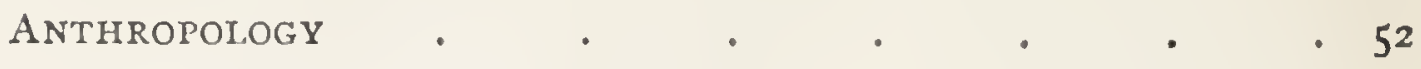

Physiology and Medicine . . . . 53

Mental and Moral Science . . . . 54

Law, Politics, and Socrology . . . 55

Works on the Physical Sciences, Mineralogy, Geology,

Etc.

TECHNOLOGY .

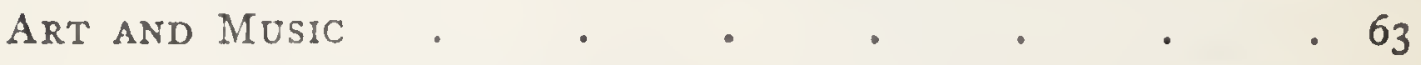

Poetry and Belles-I_ettres . . . . . 64

NOVELS AND WORKS OF FICTION • • . . 7 I

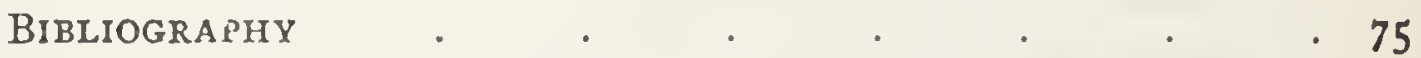

Gastronomy and Diet, Chess Manuais, and Miscellaneous

WORKS • • • • • • . 76

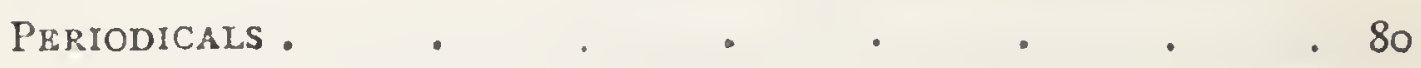




\section{Kegan Paul, Trench, Trübner, \& Co.'s PUBLICATIONS.}

NotE. - The letters I. S. S. denote that the Work forms a Volume of the International Scientific Series.

\section{WORKS ON ORIENTAL SUBJECTS,}

EMBR.ACING

The Religions, Literature, Philosophy, History, Geography, and Archaology of India, China, Japan, Persia, Arabia, and Palestine.

\section{WORKS RELATING TO INDIA, ETC.}

Alberuni's India: An Account of the Religion, Philosophy, Literature, Geography, Chronology, Astronomy, Customs, Law's, and Astrology of India, about A.D. 1030. Arabic Text, edited by Professor E. Sachau. 4to, $£ 3,3$ s.

History of India, as told by its own Historians: the Muhammadan Period. From the Posthumous Papers of the late Sir H. M. Eltiot. Revised and continued by Professor John Dowson. 8 vols. 8 vo, $£ 8,8$ s.

History, Folk-Lore, and Distribution of the Races of the North-Western Provinces of India. By Sir II. M. ElLLIOT, edited by J. Brames. With Four Coloured Maps. 2 vols. 8vo, Li, I6s.

Hindu Mythology and History, Geography, and Literature, Classical Dictionary of. By JOHN Dowson. Post 8iro, 16 s.

[Trübner's Orlental Series.

History of India from the Earliest Ages. By J. 'Talbovs Wherler. 8vo. Vol. I. containing the Vedic Period and the Mahá Bhárata, with Map. Vol. II. The Kamayana and the Brahmanic Period, with two Maps, 2Is. Vol. III. Mlindu, Buddhist, and Brahmanical Revival, with two Maps, 18s. Vol. IV. Part I. Mussulman Rule, I 4 s. Vol. IV. Part II. Completing the History of India down to the time of the Moghul Empire, I2s.

* Vol. III. is also published as an independent work under the title of 'History of India: Hindu, Buddhist, and Brahmanical.' 
Original Sanskrit Texts, on the Origin and History of the People of India. By John MUik. Vols. I., II., IV., and V., 2Is. each; Vol. III. I6s. Second Edition. 5 vols. Svo.

Caste.-Mythical and Legendary Accounts of the Origin of Caste. By John MuIr. Third Edition. ŁI, Is.

* * This work is also issued as a volume of Trübner's Oriental Series, at the same price.

Trans-Himalayan Origin of the Hindus, By JoHN MuIR. Second Edition. ¿I, Is.

The Vedas. By John Muir. Second Edition. I6s.

Cosmogony, Mythology, etc., of the Indians in the Vedic Age. By JOHN MUIR. Third Edition. LI, Is.

Comparison of the Vedic with the Later Representations of the Principal Indian Deities. By John MuIr. Second Edition. ¿I, Is.

Sacred Hymns of the Brahmins, as preserved in the Oldest Collection of Religious Poetry, the Rig-Veda-Sanhita. By F. MAX Múller. Vol. I. Hymns to the Maruts, or the Storm Gods. Svo, 12s. $6 d$.

Rig Veda Sanhita: A Collection of Ancient Hindu Hymns, from the Sanskrit. By H. H. Wilson. Edited by E. B. Cowell and W. F. WEBSTER. 6 vols. $8 v 0,27,7 s . \quad$ Only a few sets are still left for sale. Vols. V. and VI. separate, at 2Is, each.

Vishnu Puráná: A System of Hindu Mythology and Tradition, from the Original Sanskrit. Illustrated by Notes derived chiefiy from other Puránás. By H. H. Wilson. Edited by FitzEDWARI) HaLl. 6 vols. $£ 3,4 s .6 d$.

The Megha-Duta (Cloud Messenger). Translated from the Sanskrit. of Kalidasa by H. H. WiLson. With Vocabulary by F. Johnson. Third Edition. 4to, IOs. 6 d.

Hindu Religion.-Essays and Lectures, chiefly on the Religion of the Hindus. By H. H. Wilson. Collected and edited by Dr. REINHOLD ROST. 2 vols. 2 Is.

Ordinances of Manu. Translated from the Sanskrit. By E. W. Hopkins, with an Introduction by the late A. C. BURnell. Post 8vo, I2s.

[Trübner's oriental Series.

Manava-Dharma Castra: The Code of Manu. Original Sanskrit Text, with Critical Notes, by J. Jolly. Post 8vo, Ios. $6 d$.

[Trübner's Oriental Sorles.

Sankhya Aphorisms of Kapila, with Illustrative Extracts from the Commentaries, by J. R. Ballantyne. Third Edition. Post 8vo, i6s.

[Trübsor's Oriontal gerles. 
Upanishads, Philosophy of the. By A. E. Gough. Post $8 v 0,95$.

[Trübner's Ortental Series.

Sarva-Darsana-Samgraha: A Review of the different Systems of Hindu Philosophy, by E. B. Cowell and A. E. Gough. Post 8vo, IOs. $6 \%$.

[Trübner's Orlental Series.

Hindu Pantheism.-Manual of Hindu Pantheism: The Vedantasara. By G. A. JАСОВ. Third Edition revised. Post 8vo, 6s.

[Trübner's Oriental series.

Religions of India. By A. BARTh. Translated by J. Wood. Sccond Edition. Post Svo, 16s.

[Trubner's Oriental Series.

Oriental Religions and their Relation to Universal Religion. India. By SAmuel Johnson. 2 vols. 21 s.

[Phlloyophical Library.

Indian Literature, History of. Translated from the German of A. Weber by J. Mani and T. Zacharie. Second Edition. Post 8vo, 10s. 6\%.

[Trübner's Oriental Series.

Nepal and Tibet, Essays on the Languages, Literature, and Religion of. By B. H. Hodgson. Royal svo, i 4 s.

Birth of the War God: A Poem from the Sanskrit of KaLIDasá. By R. T. H. Griffith. Second Edition. Post 8vo, 5 s.

[Trübner's Oriental Serieq

Nagananda; or, The Joy of the Snake World, from the Sanskrit of Sri-Harsha-Deva, by P. Boyd. Crown 8vo, 4 s. $6 d$.

Metrical Translations from Sanskrit Writers. By JoHN Muik. Post Svo, its.

[Trübner's Orlental series.

Sanskrit Dramas, Short Introduction to the Ordinary Prakrit of the. By E. B. Cowell. Crown Svo, 3s. 6d.

Hindu Drama.-Select Specimens of the Theatre of the Hindus, from the original Sanskrit, by H. H. WiLson. Third Edition. 2 vols. $21 s$.

Imperial Gazetteer of India. By Sir W. W. Hunter. New Edition, with Mafs, I886.1887. I4 vols. half-morocco, $£ 3,3$ s.

Ancient Geography of India. By Major-General Alexander Cunningham. I. The Buddhist Period, including the Campaigns of Alexander, and the Travels of Hwen-Thsang. With Thirteen Maps. 8vo, $6 \mathrm{I}, 8$ s. 
Buddhist Cave-Temples and their Inscriptions. Containing Views, Plans, Sections, and Elevations of Façades of CaveTemples; Drawings of Architectural and Mytholngical Sculptures; Facsimiles of Inscriptions, etc. With Descriptive and Explanatory Text, and Translations of Inscriptions, by JAMES BURGESS. 86 Plates and Woodcuts. Koyal 4to, half-lound, $\& 3,3$ s.

Elura Cave Temples, and the Brahmanical and Jaina Caves in Western India. By James BURGess. With Sixty-six Plates and Woodcuts. Royal 4to, half-bound, 2 2'ols, L.6, $6 \mathrm{~s}$.

[Arch. Survey of Western India.

Elements of South Indian Palæography, from the Fourth to the Seventeenth Century. An Introduction to the Study of South Indian Inscriptions and MSS. By A. C. BURNELL. Enlarged Edition. With Map and Thirty-five Plates. 4to, £2, i2s. $6 d$.

Maha-Vira-Charita: or, The Adventures of the Great Hero Rama, from the Sanskrit of Bhavabiüt, by John PICKFord. Crown 8vo, 5 s.

Satakas of Bhartrihari. Translated from the Sanskrit by B. H. Wortham. Post 8vo, 5 s.

[Trübner's Orlental serles.

Kashmir, Folk Tales of. By J. H. Knowles. Post 8vo, i6s.

Ancient Proverbs and Maxims from Burmese Sources; or, The Niti Literature of Burma. By J. Gray. Post 8vo, 6s.

[Trübner's Orlental Serles.

Tibetan Tales, derived from Indian Sources. Done into English from the German of F. Anton von Schiefner hy W. R. S. Ralston. Post 8vo, 14 s.

[Trübner's Orlental Serles.

Parsis.-Essays on the Sacred Language, Writings, and Religiun of the Parsis. By M. IlAUG. Third Edition. Edited and enlarged by E. W. West. Post 8vo, r6s.

[Trübner's Orlental Serles.

Burma, History of, including Burma Proper, Pegu. Taungu, Tenasserim, and Arakan, from the Earliest Tiıne to the end of the first war with British India. By General Sir A. Phayre. Post 8vo, I 4 s.

[Trübner's Orlental Serles.

Burma: As it Was, as it Is, and as it IVill be. By JAmeS GeORGe SCOTT. Cheap Edition. Crown 8vo, 2s. $6 d$.

British India, Early Records of. A History of the English Settlement in India, as told in the Government Records and other Contemporary Documents. By J. TAlboys Wheeler. Royal 8vo, I5s.

India Past and Present: Historical, Social, and Political. By James Samuelson. With Map, Woodcuts, Views, Portraits, etc. $8 v 0,2 \mathrm{I}$ s. 
India Revisited. By Sir Edwin ARnold. With Thirty-two Full-page lllustrations. Crown 8vo, 7s. 6d.

English Rule and Native Opinion in India. By JAMES Routlenge. $8 v o, 10 s .6 d$.

Rajas of the Funjab: History of the Principal States in the Punjab, and their Political Relations with the British Government. By sir Lepel lirtafin. Royal Szo, 21 s.

Modern India and the Indians: A Series of Impressions, Nontes, and Essays. By Sir M. MonizR-Will l.tams. Fifth Edition. Post 8vo, 14s.

[Trübner's Orlental Serles.

India. By Sir John Strachey. With Map. 8vo, I5s.

New India; or, India in Transition. By H. J. S. Cotton. Third Edition. Crown 8vo, 45.6u.; Cheap Edition, paper covers, is.

Essays relating to Indian Subjects. By B. H. Hodgson. 2 vols. Post 8vo, 28 s. [Trübner's Orlental series.

Mediæval Researches from Eastern Asiatic Sources: Fragments towards the Knowledge of the Geography and History of Central and Western Asia from the Thirteenth to the Seventeenth Century. By E. Bretschneider. With Two Maps. 2 vols. post $820,21 s$.

[Trübner's Orlental serles.

Languages of India. See Works on Comparative Philology, The Science of Langunge, etc.

Indo-China, Papers relating to. Reprinted from DALRYMPLE'S Oriental Repertury, Asiatick Researches, and the Journal of the Asiatic Suciety of Bengal. Post 8r\%. 2 vols. 21s. ; Second Series, 2 vols., 25 s.

[Tribner's Orlental Serles.

\section{WORKS ON ORIENTAL BUDDHISM.}

Buddhist Catechism; or, Outline of the Doctrine of the Buctlha (jotama. By Subrat)ra Bhikshu. 12mo, 25.

Chinese Buddhism, Handbonk for the Student of. By E. J. Eitel. Second Edition. Crown 8vo, 18 s.

Buddhism in Tibet. By EMIL SCHLAGintweit. Illustrated by L.werary Ilocuments and Chiects of Keligious Worship. With Twenty l'lates. 2 vols. roya! 8 wo and jolio, $L 2,25$.

Chinese Buddhism: Sketches Historical and Critical. By J. Edkins, D.D. Post 8vo, 18 s.

[Trübner's Orlental serlos. 
Buddha and his Doctrines: A Bibliographical Essay. By OtTo KistNer. 4to, 2s. $6 d^{\circ}$.

Buddha, Popular Life of. Containing an Answer to the Hibbert Lectures of I 88 $\mathrm{x}$. By ARTHUR LILLIE. With Illustrations. Crown 8vo, 6s.

Life of the Buddha, and the Early History of his Order, derived from Tibetan Works in the Bkah-Hgyur and the BstanHgyur. By W. W. Rockhill. Post 8vo, ros. 6d.

['Trübner's Orlental serles.

Romantic Legend of Sakya Budaha, from the Chinese Sanskrit. By S. Beal. Crown 8vo, I2s.

Buddhist Scriptures, Catena of, from the Chinese. By S. BEAL. 8vo, 15 s.

Si-Yu-Ki: Buddhist Records of the Western World. Translated from the Chinese of HiUen Tsianc, (A.n. 629) hy S. Bral. With Maps. 2 vols. post Svo, 24 s.

[Trübner's Orlental Series.

Hiuen-Tsiang, Life of. By the Shamans Hwur $L I$ and YEN-TSUNG, with an Account of the Works of I-TSING. By S. Beal. Post 8vo, 10 .

[Trübner's Orlental series.

Dhammapada. - Texts from the Buddhist Canon, commonly known as Dhammapada. Translated from the Chinese by S. Bral. Post 8vo, 7s. 6 6 .

[Trübner's Orlental Series.

Udanavarga: A Collection of Verses from the Buddhist Canon, compiled by DHARMATRÂTA, and translated from the Tibetan, by W. W. RockHill. Post Svo, 9s.

[Trübner's Oriental Series.

Buddhism in Christendom ; or, Jesus the Essene. By ARTHUR Lillie. With Illustrations. Svo, i 5 s.

The Dathavansa: or, The History of the Tooth-Relic of Gotama Buddha. Pali Text with translation by Sir MUTu Coomara Swamy. 8vo, ros. 6d. English Translation only, 6s.

Sutta Nipata; or, Dialogues and Discourses of Gotama Buddha. Translated from the Original Pali by Sir M. CoomarA Swamy. Crown 8vo, 6s.

The Jataka, together with its Commentary, being Tales of the Anterior Birth of Gotama, now first published in Pali. By V. FAUSBOLL. 5 zols. $8 v 0,28$ s. each.

Buddhist Birth-Stories; or, Jataka Tales, the Oldest Collection of Folk-Lore extant; Being the Jàtakatthavannanā, translated from the Pali Text of V. FAusboll, by T. W. RhYS-DAvids. Vol. I., Post $8 v 0, x 8 s$. 
Indian Buddhism. The Indian Religions; or, Results of the Mysterious Buddhism, by Hargrave Jennings. Svo, 10s. $6 d$.

Reports of the Amaravati and Jaggayyapeta Buddhist Stupas. Containing numerous Collotype and other Illustrations of Buddhist Sculpture and Architecture, etc., in South-Eastern India; Facsimiles of Inscriptions, etc., with Descriptive and Explanatory Text; tugether with Transcriptions, Translations, and Elucidations of the Dhauli and Jaugada Incriptions of Asoka. By JAMES BuRgess. Numerous Plates and Woodcuts. Royal 4to, half-bound, $£ 4,4$.

\section{WORKS RELATING TO CHINA.}

Religion in China. Containing a Brief Account of the Three Religions of the Chinese. By J. EDkins, D. D. Third Edition. Post Svo, 7s. 6d.

[Trübner's Oriental Series.

* * This Work is also issued as a Volume of the Philosophical Library.

Chinese Buddhism; Sketches Historical and Critical. By J. Edkins, D.D. Post 8vo, $18 s$.

[Trübner's Orlental Serles.

Chinese Researches, Chinese Chronology and Cycles. By T. Fergusson. Crown $8 v o, 10 s .6 \%$.

Chinese Language and Literature. By Professor R. K. Douglas. Crown 8vo, 5 s.

Jenghiz Khan, Life of. Translated from the Chinese by Professor R. K. Douglas. Crown 8vo, 5 s.

Confucius, the Great Teacher. By Major-General G. G. Alexander. Crown 8vo, $6 \mathrm{~s}$.

Mencius.-The Mind of Mencius; or, Political Economy founded upon Moral Philosophy. A Systematic Digest of the Doctrines of the Chinese Philosopher Mencius. Translaled from the German of FABER, with additional Notes, by A. B. Hutchinson. Post 8vo, 10s. $6 \%$.

[Trübner's Orlental Series.

Chinese Classics. Translated into English by James LegGe. Popular Edition. Crown 8vo. Vol. I. Life and Teachings of Confucius. Sixth Edtition, IOs. 6i. Vol. Il. Works of Mencius, I2s. Vol. III. She-King, or Book of Poetry, I2s.

Chinese Scrap-Book, Leaves from my. By F. H. BALFour. Post 8vo, 7s. 6d.

Folk-Lore of China, and its Affinities with that of the Aryan and Semitic Races. By N. B. Dennys. 8vo, 10s. 6d.

Tsuni-lGoam, the Supreme Being of the Khoi-Khoi. By T. HАнN. Post 8vo, 75. 6d.

['Trübner's Ortenta] \&eries. 
Chinese Characteristics. By Arthur H. Smith. 8vo, 7s. 6d.

Chinese Philology and Languages. See Works on Com Parative Philology, The Science of Language, etc., and likewise Catalogue of Chinese and Japanese Books, New and Secondhand, sent post free for $3 d$.

\section{WORKS RELATING TO ISLAM.}

Tentative Chronological Synopsis of the History of Arabia and its Neighhours, from B.C 500,000 (?) to A.D. 679. By J. W. Redhousk. 8vo, paper, is.

History, System, and Varieties of Turkish Poetry, illustrated by Specimens in the Original English Paraphrase. By J. W. ReDhouse. $8 v o, 2 s .6 d$.

The Mesnevi (usually known as the Mesneviyi Sherif, or Holy Mesnevī) of Mevlānā (Our Lord), Jelālu'd-Din Muhammed Er-Rūmi. Illustrated by a Selection of Characteristic Anecdotes. Translated by J. W. Redhouse. Post 8vo, EI, Is.

[Trübner's Orlental Series.

Selections from the Koran. By E. W. Lane. New Edition, with Introduction by Stanley Lane Poole. Post 8vo, 9s.

[Trübner's Oriental Series.

Comprehensive Commentary to the Quran. By E. M. WhERRY. With SALE'S Preliminary Discourse, and Additional Notes. Post 8vo. Vols. I. II. and III., I2s. 6d. each. Vol. IV., IOS. $6 d$.

[Trübner's Orlental Series.

Book of Kalilah and Dimnah. Translated from Arabic into Syriac, with Preface and Glossary in English, by W. WIIGHT. 8vo, 2 Is.

Islam; or, True Christianity. By ERnest DE Bunsen. Crown 8vo, 5 s.

The Future of Islam. By W. S. Blunt. Crown 8vo, 6s.

Languages of Islam, etc. See Works on Comparative Philology, The Science of Language, etc.

\section{PERSIAN LITERATURE, ETC.}

The Gulistan; or, Rose Garden of Shekh Mushliu'd-Din Sadi of Shiraz. Translated from the Atish Kadah, by E. B. EAsTwick. Second Edition. Post 8vo, 10s. $6 d$.

['îüüner's Orlental Series

The Vazir of Lankuran ; A Persian Play, with a Grammatical Introrluction, Translation, Notes, and Vocabulary, by W. H. HAGGard and G. Le StrRange. Crown 8vo, Ios. 6d.

Oriental Religions and their Relation to Universal Religion. By Samurl Johnson. Persia. 8vo, i8s. 
Yúsuf and Zulaika; A Poem by Jam. Translated from the Persian into English Verse by R. T. H. Griffith. Post 8vo, 8s. $6 d$. [Trübner's Orlental Serles.

Persian Language. See Works on Comparative Philology, The Science of Language, etc.

\section{WORKS RELATING TO JAPAN.}

The Mikado's Empire. By W. E. Griffis. Book I. History of Japan from B.C. 660 to A.D. 1872 . Book II. Personal Experiences, Observations, and Studies in Japan, 1870-1874. Second Edition, lllustrated. 8vo, 20s.

Classical Poetry of the Japanese. By Basil Chamberlain. Post 8vo, 7s. 6d.

[Trübner's Oriental Serles.

Japanese Fairy World; Stories from the Wonder-Lore of Japan. By W. E. Griffis. With Twelve Plates. Square 16mo, 3s. $6 d$. Things Japanese. By Basil Chamberlain. Cr. 8vo, 7 s. $6 d$. Japanese Language. See Works on Comparative PhiloIogY, The Science of LANGUAge, etc., and likewise Catalogue of Chinese and Japanese Books, New and Second-hand, sent post free on receipt of $3 d$.

\section{JEWISH HISTORY AND RELIGION,}

Talmudic Miscellany; or, One thousand and one Extracts from the Talmud, the Midrashim, and the Kabbalah. By J. P. HERSHON. Post 8vo, 14 s.

[Trübner's Ortental Series.

Book of Nabathæan Agriculture, Age and Antiquity of the. By Ernest Renan. Crown 8vo, 3s. $6 d$.

Maimonides' Guide of the Perplexed, from the Original Text, Annotated by H. FriedLÄnder. 3 vols. post $8 v o$, 3 Is. $6 d$.

[Philosophica] Library.

Text Book of Jewish Religion. Second Edition, Revised. By M. Friedländer. Crown 8vo, is. $6 \%$.

The Jewish Religion. By M. Friedländer. Cr. 8vo, $5 \mathrm{~s}$. Hebrow Language. See Works on Comparative Phila LOGY, The Science of Language, etc.

\section{ARCHAEOLOGY, ETC., OF EGYPT AND ASSYRIA.}

History of Esarhaddon (Son of Sennacherib), King of Assyria, B.C. 681-668. Translated from the Cuneiform Inscriptions in the British Museum, by E. A. Budge. Post 8vo, 10s. $6 \%$.

[Trübner's Orlental Series. 
Archaic Classics, Assyrian Texts. Being Extracts from the Annals of Shalmaneser 11., Sennacherib, and Assur-Bani-Pal, with Philological Notes, by E. A. Budge. Small 4to, 7s. $6 d$.

Egyptian Religion, History of the. By Professor C. P.

Tielz. Translated by J. Ballingal. Post $8 v o, 7 s .6 d$.

[Trübner's Ortental Series.

\section{WORKS ON COMPARATIVE PHILOLOGY, THE SCIENCE OF LANGUAGE, GRAMMARS, LEXICONS, ETC.}

Study of Language, Introduction to the; The History and Methods of Comparative Philology of the Indo-European Languages. By B. DelbRuck. 8vo, 5 s.

Science of Language, Introduction to the. By A. H. SAYCE. New and Cheaper Edition. 2 vols. crown Svo, 9 s.

The Alphabet; An Account of the Origin and Development of Letters. By Canon ISAAC TAYLOR. 2 vols. 8vo, $36 \mathrm{s.}$

Comparative Grammar of the Indo-European, Sanskrit, Greek, and Latin Languages. By AUgusT Schleicher. Translated from the Third German Edition by H. Bendall. 8vo, I3s. $6 d$.

Comparative Grammar of the Dravidian or South Indian Family of Languages. By Bishop R. CAI.DWRLL. Enlarged Edition. 8vo, 28s.

Linguistic Essays. By Carl Abel. Post 8vo, 9s.

[Trübner's Oriental serles.

Slavic and Latin: Lectures on Comparative Lexicography, by CARL ABEL. Post 8vo, 5 s.

Fortunes of Words, The. By Federico Garlanda. Crown $8 v 0,5$ s.

Philosophy of Words; A Popular Introduction to the Science of Language. By Federico Garlanda. Crown 8vo, 5 s.

Language, Life and Growth of. By Professor W. D. Whitney. Fifth Edition. Crown 8vo, 5s.

Language and the Study of Language. By Professor W. D. Whitney. Fourth Edition. Crozun 8vo, ros. $6 d$.

Language and its Study; with Especial Reference to the Indo-European Family of Languages. By Professor W. D. Whitney. Edited by R. MORRIS. Second Edition. Crown 8vo, 5 s.

Cuneiform Inscriptions, Abridged Grammar of the Languages of the. By GeORGE BERTIN. Crown 8vo, 5 s. 
Linguistic and Oriental Essays. By R. Cust. Post 8vo. First Series, IOs. 6d.; Second Series, with Six Maps, 21s. Third Series, 21 s.

[Trübner's Oriental Serles.

Indo-Germanic Languages, Comparative Grammar of the. By Karl. BrugmanN. 2 vols. 8vo. Vol. I. I8s.; Vol. II. I6s.

Comparative Grammar of the Modern Aryan Languages of India; Hindi, Panjabi, Sindhi, Gujarati, Marathi, Oriya, and Bengali. By John Beamrs. 3 vols. 8vo, 16 r. each.

Modern Languages of the East Indies. By R. Cust. With Two Language Maps. Post 8vo, 7s. 6d.

[Trübner's Oriental Serles.

Urdù.-Grammar of the Urdū or Hindūstāni Language. By John Dowson. Second Edition. Crown 8vo, 10s. 6d.

Hindūstāni Exercise Book: Passages and Extracts for translation into Hindūstāni. By JoHn Dowson. Crown 8vo, 2s. 6\%.

English-Hindūstānī and Hindūstānī-English Dictionary. By T. Craven. Second Edition Revised and Enlarged. 18mo, 4s. 6d.

Pali Language, Simplified Grammar of the. By E. Müller. Crowun 8vo, 7s. 6d.

Pali-English Dictionary, with Sanskrit Equivalents. By R. C. Childers. Imperial 8vo, £3,3s.

Panjābi Language, Simplified Grammar and Reading Book of the. By W. St. Clair Tisdall. Crowin 8vo, 7s. 6d.

Suahili Language, Dictionary of the. By L. KRAPF. 8vo, 30 s.

Hindi and Braj Bhakha Grammar, Elements of. Compiled for the East India College at Haileybury. By J. R. Balinantryne. Second Edition. Crown Svo, 5 s.

Sanskrit Grammar, First Lessons in. By J. R. Ballantyne. Fourth Editzon. 8vo, 3s. 6 d.

Compendious Sanskrit Grammar, with a Brief Sketch of Scenic P'rakrit. By H. Edgren. Crown 8vo, IOs. 6\%.

Sanskrit Language, Grammar of the, for the use of Early Students. By Throdor Benfey. Second Edition. Royal 8vo, IOS. $6 d$.

Prakrita-Prakasa; or, The Prakrit Grammar of VARARUCHI, with the Commentary (Manorama) of Bhamaha. By E. B. Coweli. $8 v 0,145$.

Sanskrit Literature: Essays, Analytical, Critical, and Philological, on Subjects connected with Sanskrit Literature. By H. H. Wilson. Collected and Edited by Dr. RFinhold Rost. 3 vols. 65,5 s. 
Sanskrit Grammar, including both the Classical Language and the Older Dialects of Veda and Brahmana. By Professor W. D. WhITNRY. Second Edition. 8vo, 125 .

Chinese Language, Syllabic Dictionary of the. Arranged according to the Wu. Fang luen l'in. With the pronunciation of the characters as heard in Pekin, Canton, Amuy, and Shanghai. By S. Whils WILliams. $46, £ 3,155$.

Tibetan Grammar. By II. A. J ̈.schkE. Prepared by Dr. H. Wrexzl. Second Edition. C'rown 8vo, 5 s.

Japanese and Englisb Dictionary. By J. C. HEPrURN. Second Edition. Imperial 8vo, half-roan. Published at L8, reduced (1) $18 \mathrm{~s}$.

Japanese-English and English-Japanese Dictionary. By J. C. IIEPBUKN. Foumh Eitution, royal $8 v 0$, half-morocco, cloth sides, 30s. Third or Jocket Edition, syuare 16 mo, 14 s.

Chinese-Japanese Words in the Japanese Language, Dictionary of. By J. H. Cubbins. Part I. (A to J), Part II. (K to R). Crown 8vo, 75. 6d. each fart.

Japanese Grammar, simplified. By Basil Chamberlain. Crown 8vo, 5 s.

Japanese Reader, Romanised. Consisting of Japanese Anecdotes and Maxims. With English Translations and Notes. By Basil. Chamberlain. I mo, 6 s.

Handbook of Modern Arabic. By Francis William NewMan. Post 8vo, 6s.

Modern Arabic, Dictionary of (Anglo-Arabic and AraboEnglish). By F. W. Newman. 2 vols. crown $8 v 0, £ \mathrm{I}, 1$ s.

Arabic-English Dictionary. Comprising about I 20,000 Arabic words, with Enylish Index of about 50,000 words. By 1I. A. SALMONÉ. 2 vols. post $8 v 0,36 s$.

Introduction to the Arabic of Morocco. English-Arabic Vocabulary, Grammar, Notes, etc. By J. E. Budgetit Mrakin. Frap. 8vo, 6s.

Ottoman Turkish, Simplified Grammar of the. By J. IV. Kenhouse. Crown 8vo, 10s. $6 d$.

Turkish Vade-Mecum of Ottoman Colloquial Language. English.Tulkish and Turkish-English. The whule in English characters, the pronunciation being fully indicated. By J. W. REDHOUSE. Third Edition. 32mo, 6s.

Grammar of the Khassi Language. By H. RoBerTs. Crown 8vo, 10s. $6 d$.

A Simplified Grammar of the Gujarāti Language, together with a short Reading Book and Vocabulary. By the Rev. W. ST. Cl.air Tisdall. Crown 8vo, ios. $6 d$. 
Persian for Travellers. By Alexander Finn. Oblong, $32 m 0,5$ s.

Persian-English Dictionary. By E. H. Palmer. Second Edition. Royal $16 m o$, IOs. 6 \%

Persian Grammars,-Simplified Grammar of Hindustani, Persian, and Arabic. By E. H. Palmer. Second Edition. Crown Svo, 5 s.

English-Persian Dictionary, with Simplified Grammar of the Persian Language. By E. H. PAlmer. Royal 16 mo, Ios. 6d.

Bantu.-A Language Study based on Bantu. An Inquiry into the Laws of Root-Formation. By F. W. Kolbe. 8vo, 6s.

Malagasy Language, Concise Grammar of the. By G. IV. PARKer. Crown 8vo, 5 s.

Samoan Language, Grammar and Dictionary of the. By George Pratr. Second Edition. Crown 8vo, I8s.

Modern Greek, Guide to. By E. M. Geldart. Post 8vo, 7s. $6 d$. Key, 2s. $6 d$.

Modern Greek, Simplified Grammar of. By E. M. GeldarT. Crown 8vo, 2s. 6d.

Lexicon of Modern Greek-English and English Modern Greek. By N. Contopoulos. 2 vols. 8vo, 27s.

Basque Grammar, Outlines of. By W. VAN Eys. Crown 8vo, 3s. $6 d$.

Romany. - English Gipsies and their Language. By C. G. Leland. Second Edition. Crown 8vo, 7s. 6d.

Grammaire Albanaise, à l'usage de ceux qui désirent apprendre cette langue sans l'aide d'un maître. Par P. W. Crown $8 v 0,7 s .6 d$.

Hungarian Language, Simplified Grammar of the. By I. Singer. Crown 8vo, 4s. 6d.

Roumanian Language, Simplified Grammar of the. By R. Torceanu. Croiun 8vo, 5 s.

Simplified Serbian Grammar. By W. R. Morfin.t. Crown 8vo, 4 s. $6 a$.

A Progressive Grammar of Common Tamil. By Rev. A. H ARIF.N. $8 v 0,5^{s}$. 
Comparative Grammar of the South African Bantu Languages, comprising those of Zanzibar, Mozambique, the Zambezi, Kafirland, Benguela, Angola, The Congo, The Ogowe, The Cameroons, the Lake Region, etc. By J. TORREND. Super-royal 8vo, 25 s.

A Comprehensive Grammar of the Sinhalese Language. By Abraham Mendis Gunasikara. 8vo, i2s. $6 d$.

Polish Language, Simplified Grammar of the. By W. R. Morfill. Crown 8vo, 3s. 6 \%

Russian, How to Learn; A Manual for Students, based upon the Ollendorffian system. By Henry Riol. Fourth Edition. Croun 8vo, I2s. Key, 5 s.

Russian Reader, with Vocabulary, by Henry Riola. Crown $8 v 0$, IOs. $6 d$.

Spanish Language, Simplified Grammar of the. By W. F. Harvey. Crown 8vo, 3s. $6 d$.

Spanish Teacher, and Colloquial Phrase-Book. By F. Butuer. I 8 mo, half-roan, $2 s .6 d$.

Spanish and English Languages, Dictionary of the, for the use of young Learners and Travellers. By M. DE LA CADENA Velasquez. Crown 8vo, $6 \mathrm{~s}$.

Spanish and English Languages, Pronouncing Dictionary of the. By Velasquez. Royal 8vo, £I, 4s.

Spanish Reader, New. By Velasquez. Containing Passages from the most approved authors. With Vocabulary. Post $8 v 0,6 s$.

Spanish Conversation, Introduction to. By Velasquez. I $2 m 0,2 s .6 d$.

Spanish Language, New Method to Read, Write, and Speak the Spanish Language. Adapted to Ollendorff's system. By Velasquez and Simonné. Revised Edition. Post 8vo, 6s. Key, 4s.

Portuguese and English, Grammar of. Adapted to Ollendorff's system. By A. J. D. D'Orsey. Fourth Edition. I2mo, $7 s$.

Colloquial Portuguese ; or, The Words and Phrases of Everyday Life. By A. J. D. D'Orsey. Fourth Edition. Crown 8vo, 3s. $6 d$.

Portuguese and English Languages, Pocket Dictionary of the. By Vieyra. 2 vols. post 8vo, ios. 
Metodo para apprender a Leer, escribir y hablar el INGLÉs segun el sistema de Ollendorff. By CARreÑo. 8vo, 4i. $6 d$. Key, $3 s$.

Italian Conversation, Manual of. By John Millhouse. I $8 m o, 2 s$.

English and Italian Dictionary. By John Millhouse. 2 vols. 8vo, $12 s$.

L'Eco Italiano: A Guide to Italian Conversation. By E. CAMERINI. With Vocabulary. I2mo, 4s. $6 d$.

Italian, Method of Learning. By F. Ahn. I2mo, 3s. $6 d$.

German Language, Grammar of the. By F. Ahn. Crown $8 v 0,3$ s. $6 d$.

German Lauguage, Method of Learning German. By F. AHN. I2mo, 3s. Key, 8d.

German and English Conversations; or, Vade Mecum for English Travellers. By F. AHN. I2mo, Is. 6 .

German Reader, Graduated: A Selection from the most Popular Writers. With a Vocabulary. By F. OTTo FrœMBLing. Tenth Edition. $12 \mathrm{mo}, 3 \mathrm{~s} .6 \mathrm{~d}$.

German.-Graduated Exercises for Translation into German : Extracts from the best English authors. With Idiomatic Notes. By

F. O. Fremaling. Crown 8vo, 4s. 6d. Without Notes, 4s.

Dutch Language, Grammar of the. By F. Aнn. I $2 m o$, 3s. $6 d$.

Pennsylvania Dutch; A Dialect of South Germany, with an Infusion of English. By S. S. Haldeman. 8vo, 3s. 6d.

French Language, Grammar of the. By H. VAN LAUN. Crown 8vo. Accidence and Syntax, 4s.; Exercises, 3s. 6d.

French Grammar, Practical. By M. de Larmoyer. Part I. Crown 8vo, 3s. 6d. Part II. Syntax. Crown 8vo, 3s. 6d.

French Grammar, adopted by the Imperial Council of Public Instruction. By A. Roche. Crown 8vo, 3 s.

French Translation. Prose and Poetry, from English Authors, for reading, composition, and translation. By A. Rocrik. Second Edition. Ficap. Svo, 2s. 6d.

French Translation, Materials for translating English into French. By L. Le-Brun. Seventh Edition. Post 8vo, 4s. 6d. 
French, Method of Learning. First and Second Courses. By F. AHN. I $2 m o, 3 s$. Separately, Is. 6d. each.

French, Method of Learning. Third Ccurse. By F. Ahn. I $2 m o$, is. $6 d$.

French. Modern French Reader. By Cн. Cassal and THÉODORE Karcher.

Junior Course. Tenth Edition. Crown 8vo, 2s. $6 d$.

Senior Course. Third Edition. Crown Svo, 4 s.

Senior Course and Glossary in I vol. Crown 8vo, $6 s$.

Little French Reader: Extracted from the 'Modern French Reader.' Third Edition. Crown Svo, 2s.

Glossary of Idioms, Gallicisms, and other difficulties contained in the Senior Course of the 'Modern French Reader.' By Charles Cassal. Crown 8vo, 2s. $6 d$.

Questionnaire Français: Questions on French Grammar, Idiomatic Difficulties, and Military Expressions. By Tr. Karcher. Fourth Edition. Crown 8vo, 4s. 6d. Interleaved with writing paper, 5 s. $6 d$.

Improved Dictionary, English-French and French-English. By E. Weller. Royal 8vo, 7s. $6 d$.

French-English and English-French Pocket Dictionary. By NUGENT. 24mo, 3 s.

French and English Dictionary for the Pocket, containing the French-English and English-French divisions on the same page; conjugating all the verbs; distinguishing the genders by different types; giving numerous aids to pronunciation, etc. By JoHN Bellows. Second Edition. 32mo, morocco tuck, I2s. 6d.; roan, IOS. $6 d$.

French Examination Papers set at the University of London. By P. H. BRetTe and F. Thomas. Part I. Matriculation and the General Examination for Women. Crown 8vo, 3s. 6d. Key, 5 s. Part II. First B.A. Examinations for Honours and D. Litt. Examinations. Crown 8vo, 75 .

Metodo para apprender a Leer, escribir, y hablar el Frances, segun el verdadero sistema de Ollendorff. By Simonnk. Crown 8vo, 6s. Key, 3s. 6d.

Danish Language, Simplified Grammar of the. By E. C. OTTÉ. Crown 8vo, 2s. 6\%.

Danish Language, Guide to the. By Maria Bojesen. $12 m o, 5 s$. 
English-Danish Dictionary. By S. Rosing. Crown 8vo, 8s. 6 \%

Dano-Norwegian Grammar: A Manual for Students of Danish, based on the Ollendorffian system. By E. C. OTTÉ. Third Edition. Crown 8vo, 7s. 6d. Key, 3 s.

Swedish Language, Simplified Grammar of the. By E. C. OтTÉ. Crown 8vo, 2s. 6d.

Norwegian Grammar, with a Glossary for Tourists. By M. Smith and H. Horneman. Post 8vo, 25.

Latin Grammar for Beginners. By F. Ahn. I2mo, 35.

Latin Grammar for Beginners on Ahn's System. By W. IHNE. $12 m 0,35$.

Anglo-Saxon.-Grammar of the Anglo-Saxon Tongue. By ERASMus RAsk. Translated from the Danish by B. ThORPE. Third Edition. Post 8vo, 5s. 6d.

Study of Words, On the. By Archisishop Trench. Twentieth Edition, Revised. Fcap. 8vo, 5 s.

English Past and Present. By ArChbishop Trench. Thirteenth Edition, Revised and Improved. Fcap. 8vo, 5 s.

English Grammar, Essentials of. By Professor W. D. Whitney. Second Edition. Crown 8vo, 3s. 6d.

English Grammar for Beginners. By H. C. Bowen. Ficap. $8 v o$, is.

Studies in English, for the use of Modern Schools. By H. C. Bowen. Tenth Thousand. Small crown 8vo, Is. 6d.

English Etymology, Dictionary of. By H. WEDGwOod. Fourth Edition, Revised and Enlarged. 8vo, £I, Is.

Contested Etymologies in the Dictionary of the Rev. W. W. Skeat. By H. Wedgwoon. Crown 8vo, 5 s.

Vest-Pocket Lexicon: An English Dictionary of all except familiar words, including the principal scientific and technical terms. BY JABEZ, JENKINS. $64 m 0$, roan, is. 6\%. ; cloth, Is.

Glossary of Terms and Phrases. Edited by H. PERCY SMITH and Others. Cheaper Edition. Medium 8vo, 3s. 6d.

Dictionary of English Literature and British and American Author, from the earliest accounts to the latter half of the Nineteenth Century. By S. A. Allibone. 3 vols. royal 8vo, $65,8 s$. Supplement, 2 vols, royal 8vo (1891), £3, 3 s. 
Select Glossary of English Words used formerly in Senses Different from the Present. By ARChBishop Trench. Seventh Edition, Revised and Enlarged. Fcap. 8vo, 5 s.

Welsh Philology, Lectures on. By John Rhys. Second Edition. Crown 8vo, 15 s.

Americanisms, Dictionary of: A Glossary of Words and Phrases colloquially used in the United States. By J. R. BArtlett. Fourth Edition, 8vo, 2Is.

Volapuk, Handbook of: the International Language. By C. E. Sprague. Second Edition. Crown 8vo, 5 s.

\section{WORKS ON THEOLOGY, BIBLICAL EXEGESIS, AND DEVOTIONAL SUBJECTS.}

Pulpit Commentary, The (Old Testament Series). Edited by the Rev. J. S. Exell and the Very Rev. Dean H. D. M. Spence, D.D. Super Royal 8vo. The Homilies and Homiletics by various Writers.

Genesis. By the Rev. T. Whitelaw, D.D. Introduction to the Study of the Old Testament by ARChDEAcon Farrar, D.D. Introductions to the Pentateuch by the Right Rev. H. CoTTERILL, D.D. and Rev. T. Whitelaw, D.D. Ninth Edition. I5s.

Exodus. By the Rev. Canon Rawlinson. Fourth Edition. 2 vols. 9s. each.

Leviticus. By the Rev. Prebendary MeYrick. Introductions by the Rev. R. Collins, Rev. Professor A. Cave. Fourth Edition. 15 s.

Numbers. By the Rev. R. Winterbotham. Introduction by Rev. Thomas Whitelaw, D.D. Fifth Edition. I5s.

Deuteronomy. By the Rev. W. L. Alexander, D.D. Fourth Edition. I5s.

Joshua. By the Rev. J. J. LiAs. Introduction by the Rev. A. Plummer, D.D. Sixth Edition. I2s. 6d.

Judges and Ruth. By the BISHOP OF BATH and Wrils and Rev. J. MORIsON, D.D. Fifth Edition. 10s. 6 d.

I. and II. Samuel. By the Very Rev. R. P. Smith, D.D. Seventh Edition. 2 vols. 15 s. each.

I. Kings. By the Rev. Joseph Hammond. Fifth Edition. I5s.

II. Kings. By the Rev. Canon Rawlinson. I5s.

I. Chronlcles. By the Rev. P. C. BArker. Second Edition. 15 s.

II. Chronicles, By the Rev. C. BARKer. I5s. 
Pulpit Commentary, The-Continued.

Ezra, Nehemlah, and Esther. By the Rev. Canon G. RAwlinson. Seventh Edition. 12s. 6 d.

Isatah. By the Rev. Canon G. Rawlinson. Second Edition. 2 vols. 15. each.

Jeremlah (Vol. I.). By the Rev. T. K. Cheyne, D.D. Third Edition. I5s.

Jeremiah (Vol. II.) and Lamentations. By the Rev. T. K. Cheynk, D.D. Third Edition. 15s.

Hosea and Joel. By the Rev. Professor J. J. Given, D.D. I Is.

Job. By the Rev. Canon G. Rawlinson. 2is.

Proverbs. By the Rev. W. J. DeANe and the Rev. S. T. TAYlorTASWELl. I5s.

Ezekiel (Vol. I.). By the Very Rev. E. H. Plumptre, D.D. Introduction by the Rev. T. Whitelaw, D.D. I2s. $6 d$.

Ezekiel (Vol. II.) By the Very Rev. E. H. Plumptre, D.D., and the Rev. J. Whitelaw, D.D. I2s. $6 d$.

Pulpit Commentary, The (New Testament Series). Edited by the Very Rev. H. D. M. Spence, D.D., and the Rev. Joseph S. EXELL.

St. Mark. By the Very Rev. Dean E. Bickersteth, D.D. Sixth Edition. 2 vols. 10s. 6d. each.

St. Luke. By the Very Rev. H. D. M. Spencr. 2 vols. IOs. $6 d$. each.

St. John. By the Rev. Professor H. R. Reynolds, D.D. Third Edition. 2 vols. I 5 s. each.

The Acts of the Apostles. By the BIshop of BATH and Wells. Fourth Edition. 2 vols. 10s. 6d. each.

Romans. By the Rev. J. BARMBY. I5s.

I. Corlnthians. By the Ven. Archdeacon FARRAR, D.D. Fourth Edition. I5s.

II. Corinthians and Galatians. By the Ven. ARCHDEACON FARRAR, D.D., and Rev. Preibendary E. Huxtable. Second Edition. 21 s.

Ephesians, Phillppians, and Colossians. By the Rev. Professor W. G. Blalkin, D.D., Rev. B. C. Caffin, and Rev. G. G. Findiay. Third Edition. $21 s$.

Thessalonlans, Timothy, Titus, and Phllemon. By the Bishop OF Bath and Wells, Rev. Dr. Gloag, and the Rev. D. Eales. Second Edition. I 5 s. 


\section{Pulpit Commentary, The-Continued.}

Hebrews and James. By the Rev. J. BARMBY, D.D. and Rev. PREbendary E. C. S. GiBSON. Third Edition. I 5 s.

Peter, John, and Jude. By the Rev. B. C. Caffin, Rev. A. Plummer, D.D. and the Rev. F. D. SAlMond, D. D. Second Edition. I 5 s.

Revelation. Introduction by the Rev. T. RANDALL. Exposition by the Rev. T Randall, assisted by the Rev. T. Plummer, D.D., and A. T. BOTT. Secont Edition. I5s.

Imitation of Christ. By Thomas A Kempis. Revised Translation. Elzevir 8vo (Parchment Library), Vellum, 7s. 6d.; Parchment or cloth, 6s. Red Line Edition. Ficap. 8vo, 2s. 6d. Cabinet Edition, Small 8vo, is. 6d.; Cloch limp, Is. Miniature EDITION, 32mo, with Red Lines, Is. 6d.; without Red Lines, Is.

De Imitatione Christi. Latin and English. Crown 8vo, 7s. $6 d$.

Seeds and Sheaves: Thoughts for Incurables. By LADY Lovat. Crown 8vo, 5 s.

Pascal's Thoughts. Translated by C. Kegan PaUl. Fiap. 8vo, Parchment, I2s. New Edition, Crown 8vo, 6s.

Catholic Dictionary, containing some Account of the Doctrine, Discipline, Rites, Ceremonies, Councils, and Religious Orders of the Catholic Church. Edited by Thomas ARnold. Fourth Edition. $8 v 0,21 s$.

Manual of Catholic Theology, based on Scheeben's 'Dogmatik.' By Rev. Thomas B. Scannell and Joserh Wilhelm, D.D. 2 vols. 8vo. Vol. I. I5s.

What are the Catholic Claims? By Austin Richardson. Introduca... by Rev. Luke Rivington. Crown 8vo, 3s. $6 d$.

Authority; or, a Plain Reason for Joining the Church of Rome. By Rev. Luke Rivington. Fifth. Edition. Crown 8vo, 3s. $6 d$.

Dependence; or, The Insecurity of the Anglican Position. By Rev. Luke Rivington. Crown 8vo, 5 s.

Towards Evening: Selections from the Writings of CARDINAL MANning. Fourth Edition, with Facsimile. $16 \mathrm{mo}, 2 \mathrm{~s}$.

Gospel according to Matthew, Mark, and Luke, The. Elzevir 8vo (Parchment Library), Vellum, 7s. 6d, Purchment or cloth, 6s.

Jesus Christ. By the Rev. Father Didon, of the Order of St. Dominic. 2 vols. 8vo, 21 s. 
Supernatural in Nature, The. A Verification by the Free use of Science. Hy Rev. J. W. REynolds. Third Eltition, revised and enlarget. Svo, its.

Mystery of the Universe Our Common Faith. By Rev. J. W. KEYNOLUS. 8vo, i 4 S.

Mystery of Miracles. By Rev. J. W. Reynolds. Third Edution, enlarged. Crown 8vo, 6s.

World to Come, The. Immortality a Physical Fact. By Rev. J. W. Reynolds. Crown Svo, 6s.

The Origin and Religious Contents of the Psalter. The Bampton Lectures, is89. By Canon T. K. Cheyne. Svo, i6s.

Isaiah, The Prophecies of. By Canon Cheyne. With Notes and Dissertations. Fifth Edition. 2 vols. 8vo, $25 \mathrm{~s}$.

Job and Solomon; or, The Wisdom of the Old Testament. By Canon Cheyne. 8vo, i2s. $6 d$.

The Book of Psalms; or, the Praises of Israel, with Commentary. By Cainon CHEYNe. 8vo, 16 s.

The Book of Psalms. By Canon Cheyne. Elzevir 8vo (Parchment Library), Vellum, 7s. 6i.; Parchment or cloth, 6s.

Parables of our Lord, Notes on the. By Archbishop Trench. 8vo, 12s. Cheap Edition. Fifty-sixth Thousand. 7s. 6d.

Miracles of our Lord, Notes on the. By ARCHBishop TRENCH. 8vo, I2s. Cheap Edition. Forty-eighth Thousand. 7s. 6d.

Brief Thoughts and Meditations on some Passages in Holy Scripture. By Archisisiop Trench. Third Edition. Crown 8vo, 3s. $6 d$.

Apocalypse: Commentary on the Epistles to the Seven Churches of Asia. By Archishop Trench. Fourth Eidztion, revised. Svo, 8s. 6u.

New Testament, On the Authorised Version of the. By Archibishop Trescil. Second Edzzon. 8zo, 7s.

Studies in the Gospels. By Archishop Trench. Fifth Eiblion, revised. 820, IOS. 6\%.

Synonyms of the New Testament. By ArCheishop Trench. Teuth Littion, enlarged. Siro, 125.

Sermons, New and 0ld. By Archbishop Trench. Crown $8 v 0,6 s$. 
Shipwrecks of Faith: Three Sermons preached before the University of Cambridge. By ArChbishop Trench. Fcap. 8vo, 2s. $6 d$.

Westminster and other Sermons. By ARCHBishop Trench. Crown 8vo, 6s.

Genesis, Notes on. By Rev. F. W. Robertson. New and Cheaper Edition. Small 8vo, 3s. 6d.

St. Paul's Epistle to the Corinthians. Expository Lectures. By Rev. F. W. Robertson. New Edition. Small 8vo, 5s.

Lectures and Addresses, with other Literary Remains. By Rev. F. W. Roberisun. Nezw Edition. Small 8vo, 5 s.

Sermons. By Rev. F. W. Robertson. Five Series. Small $8 v 0,3$ s. 6d. each.

* * Portrait of the late Rev. F. W. Robertson, mounted for framing, $2 s .6 d$.

Great Question, The, and other Sermons. By William Alexander, D.D., Bishop of Derry. Crown 8vo, $6 s$.

Apostles' Creed, The. Sermons by Rev. Robert Eyton. Crown 8vo, 3s. $6 d$.

True Life, The, and other Sermons. By Rev. RoBert Eyton. Crown 8vo, 7s. 6i.

The Lord's Prajer: Sermons. By Rev. Robert Eyton. Crown 8vo, 3s. 6d.

Tremadoc Sermons: Chiefly on the Spiritual Body, the Unseen World, and the Divine Humanity. By Rev. H. N. Grimlery. Fourth Edition. Crown 8vo, 6s.

Prajer of Humanity, The. Sermons on the Lord's Prayer. By Rev. H. N. GRIMleey. Crown 8vo, 3s. 6\%.

Temple of Humanity, The, and other Sermons. By Rev. H. N. Grimley. Crown Svo, 6s.

Sermons for the Church's Seasons from Advent to Trinity, selected from the published Sermons of the late Edward Bouverie Pusey, D.D. Crown $8 v o, 5$ s.

Disputed Points and Special Occasions, Sermons on. By Grorge Dawson. Edited by his Wife. Fifth Edition. Small $8 v o$, 3s. $6 d$.

Daily Life and Duty, Sermons on. By George Dawson. Edited by his Wife. Fifth Edition. Small 8vo, 3s. 6d. 
Authentic Gospel, The, and other Sermons. By George Dawson. Edited by George St. Clair. Fourth Edition. Small $8 v 0,3 s .6 d$.

Every-Day Counsels. By George Dawson. Edited by George St. Clair. Crown 8vo, 6s.

Prayers. By George Dawson. First Series. Edited by his Wife. Tenth Edition. Small 8vo, 3s.6\%. Second Series. Edited by George St. Clair. Small 8vo, 3s.6 6 .

Book of Job, Commentary on the. By Samuel Cox, D.D. With a Translation. Second Edition. 8vo, I5s.

Balaam: An Exposition and a Study. By Samuel Cox, D.D. Crown 8vo, 5 s.

Miracles: An Argument and a Challenge. By Samuel Cox, D.D. Crown 8vo, 2s. $6 d$.

Salvator Mundi; or, Is Christ the Saviour of all Men? By Samuel Cox, D.D. Twelfth Edition. Crown 8vo, 2s. 6d.

Larger Hope, The. A Sequel to 'Salvator Mundi.' Second Edition. I6mo, is.

Genesis of Evil, and other Sermons, mainly Expository. By Samuel Cox, D.D. Fourth Edition. Crown 8vo, 6s.

Formation of the Gospels. By F. P. Badham. Crozen 8vo. $2 s .6 d$.

Present Day Oounsels. By Rev. W. L. PAige Cox. Crozen $8 v 0,5$ s.

The Bible True from the Beginning: A Commentary on all those portions of Scripture that are most questioned and assailed. By Edward Gough. Vols. I. to V. 8vo. I6s. each.

Larger Hope, Our Catholic Inheritance in the. By ALFRED GURNEY. Crown 8vo, is. $6 \%$.

Meditations on Death and Eternity. Translated from the German by FreDERICA ROWAN. Published by Her Majesty's Gracious Permission. Crown Svo, 6s.

Meditations on Life and its Religious Duties. Translated from the German by Frederica Rowan. Published by Her Majesty's Gracious Permission. Crown 8vo, 6 s.

Higher Life, The : Its Reality, Experience, and Destiny. By Rev. J. Baldwin Brown. Seventh Edition. Crown 8vo, 5 s. 
Doctrine of Annihilation in the Light of the Gospel of Love. By Rev. J. Baldwin Brown. Fourth Lidition. Crown Svo, 2s. $6 d$.

Christ in Modern Life. By Rev. Stopford A. Brooke. Seventienth Edation. Crown Svo, 5 s.

Christian Life, The Spirit of the. By Rev. Stopford A. BROOKL. Fourth Edition. Crown 8vo, 5 s.

Fight of Faith, The : Sermons preached on various occasions, by Rev. Stoplord A. Brooke. Sixth Edition. Crown 8vo, 5 s.

Sermons. Two Series. By Rev. Stopford A. Brooke. Thirteenth Edition. Crozun $8 v o, 5$ s. each.

Theology in the English Poets-Cowper, Coleridge, Wordsworth, and Burns. By Rev. STOpFord A. Brooke. Sixth Edition. Post Svo, 5s.

Current Coin. By Rev. H. R. HAwers. Materialism-The Devil - Crime - Drunkenness - Pauperism - Emotion-Recreation - The Sabbath. Sixth Ectition. Crown 8vo, 5 s.

Arrows in the Air. By Rev. H. R. Haweis. Fifth Edition. Crown Svo, 5 s.

Speech in Season. By Rev. H. R. HaweIs. Sixth Edition. Crown Svo, 5 s.

Thoughts for the Times. By Rev. H. R. HAweis. Fourteenth Eddition. Crown 8vo, 5 s.

Unsectarian Family Prayers. By Rev. H. R. Haweis. New Edilion. Ficap. 8vo, 1s. 6d.

Death-and Afterwards. By Sir EDwin ARnold. Reprinted from the Fortnightly Revieze of August 1885, with Supplement. Ninth Edition. Crown 8vo, Is. 6d. Paper, Is.

Discourse on Matters Pertaining to Religion. By THEodore PARKER. People's Edition. Crozen Svo, 2s.; is. 6d.

Collected Worlzs of Theodore Parker, Minister of the TwentyEighth Congregational Society at Boston, U.S. I4 vols., 8vo, 6s. each.

Vol. I.-Discourse on matters pertaining to Religion. II. Ten Sermons and l'rayers. III. Discourses on Theolugy. IV. Discourses on Polıics. V. and VI. Di-courses on Slavery. VII. Discourses on Sucial Science. VIII. Miscellaneous Discourses. IX. and X. Critical Writings. XI. Sermons on Theism, Atheism, and Popular Theolory. XII. Autobingraphical and Miscellaneous Pieces. XIII. Historic Americans. XIV. Lessons from the World of Matter and the World of Man. 
Jesus, the Carpenter of Nazareth. By A LAyman. Third Edition. Crown Swo, 5s. Also in Tivo l'arts, 2s. 6d. each.

Hebrew Theism. By Francis IVilliam Newman. Royal $8 v 0,45.6 d$.

Christian Policy of Life, The. A Book for Young Men of Business. By Rev.J. BALdwix Brown. Third Edition. Crown 8vo, 3s. 6d.

Evolution and Scripture. With an Inquiry into the Nature of the Scriptures and Inspiration. By A\&THUR HOLBOROw. Crown $8 v 0,6 s$.

Supernatural Revelation; An Essay concerning the Basis of the Christian Faith. By C. M. MEAD, D.D. Royal 8vo, I4s.

Foly Eucharist in Great Britain, History of the. By Rev. T. E. BRIDGETT. 2 vols. $8 v o, 18 s$.

Science and the Faith: Essays on Apologetic Subjects. By Aubrey L. Moore. Third Edition. Crown Svo, 6s.

Church Histories. See General and European History.

\section{WORKS ON SPECULATIVE THEOLOGY, PHILOSOPHY, AND COMPARATIVE RELIGION.}

Spinoza's Philosophy. Ethic Demonstrated in Geometrical Order and Divided into Five Parts, which treat-(I) Of God; (2) Of the Nature and Origin of the Mind; (3) Of the Origin and Nature of the Affects; (4) Of Human Bondage, or of the Strength of the Affects; (5) Of the Power of the Intellect, or of Human Liberty. 'Translated from the Latin of Spinioza, by W. Hale White. Post Svo, 1os. $6 d$. [Phllosophical Library.

Leopardi's Philosophy. Essays and Dialogues of Leopardi. Translated by Charles Edwardes, with Biographical Sketch. Post $8 v 0,7 s .6 d$.

[Philosopical Library.

Schopenhauer's Philosophy. The World as Will and Idea. From the German of SCHOPENHAUER. By R. B. HALDANE and J. KEMP. 3 vols., Post 8vo, £2, IOs. [Pbllosophical Library.

Hartmann's Philosophy. Philosophy of the Unconscious. By E. von Hartmans. Translated by W. C. Coupland. 3 vols. Post 8vo, 3is. 6d. 
Fichte's Philosophy. Characteristics of the Present Age. By J. Gottlieb Fichte. Translated by W. Smith. Post $8 v o, 6 s$.

New Exposition of the Sclence of Knowledge. Translated by A. E. KROEGER. $8 v o, 6 s$.

Science of Knowledge. Translated by A. E. KROEGER. With an Introduction by Prof. W. T. HARRIS. IOS. $6 d$.

[Philosophical Library.

Science of Rights. Translated by A. E. Kroegre. With an Introduction by Prof. W. T. HARRIS. I 2s. 6d. [Philosophical Library.

Fichte's Popular Works. The Nature of the Scholar, The Vocation of the Scholar, The Vocation of Man, The Doctrine of Religion, Characteristics of the Present Age, Outlines of the Doctrine of Knowledge. With a Memoir by W. SMITH. 2 vols., 2 rs.

[Phllosophical Library.

Problems of Life and Mind. By George Henry Lewes. $8 v 0$. SERIES I. - Foundations of a Creed. 2 vols. $28 s$.

SERIES II. - Physical Basis of Mind. With Illustrations. I6s. Series III. - 2 vols. 22s. 6 \%

Essays, Philosophical and Theological. By James MarTINEAU. 2 vols. Crozon $8 v o, £ \mathrm{I}, 4 s$.

History of Materialism, and Criticism of its Present Importance. By Prof. F. A. LANGe. Authorised Translation by ERNesT C. Thomas. 3 vols. Post 8vo, ros. 6d. each. [Philosophical Library.

Moral Ideal, The: An Historic Study. By Julia WedGwood. Second Edition. 8vo, 9s.

Positive Philosophy of Auguste Comte. Translated and Condensed by Harriet Martineau. 2 vols. Second Edition. Post $8 v 0,25 s$.

Catechism of Positive Religion. By Auguste Comte. From the French by R. Congreve. Third Edition. Crown 8vo, 2s. 6d.

Auguste Comte and Positivism. By John Stuart Mill. Third Edition. Post 8vo, 3s. 6d.

[Philosophical Library.

Compendium of the Philosophical System of Antonio RosminiSerbati. By T. Davidson. Second Edition. 8vo, 10s. 6d.

Moral Order and Progress: An Analysis of Ethical Conceptions. By S. Alexander. Second Edition. Post 8vo, r4s.

[Philosophical Library.

Final Causes: A Refutation. By Wathen Mark Wilks Call. Crown 8vo, 5 s. 
The Worth of Human Testimony. By T. Fitzarthur. Fiap. 8vo, 2s.

Man's Origin and Destiny. Sketched from the Platform of the Physical Sciences. By J. P. Lesley. Second Edition. Crown $8 v 0,7 s .6 d$.

On Truth. By St. George Mivart. 8vo, r6s.

Natural Law: An Essay in Ethics. By Edith Simcox. Secona Edition. Post 8vo, 10s. 6d.

[Philosophical Library.

Essays, Scientific and Philosophical. By Aubrey L. Moore. With Mlemoir of the Author. Crown 8vo, 6s.

IMystery of Pain. By James Hinton. Nere Edition. Fcap. $8 v 0$, I $s$.

Law-Breaker, The, and The Coming of the Law. By James linton. Edited by Margaret Hinton. Crown 8vo, 6s.

Philosophy and Religion. Selections from the MSS. of the late James Hinton. Edited by Caroline Haddon. Second Edition. Crown 8vo, 5 s.

Larger Life, The. Studies in Hinton's Ethics. By CaroIINE HADDON. Crown 8vo, 5 s.

Phases of Faith; or, Passages from the History of my Creed. By F. W. Newman. Crown 8vo, 3 s. $6 d$.

The Soul: Her Sorrows and her Aspirations. By F. W. Newman. Tenth Edition. Post 8vo, 3s. 6d.

Miscellanies. Essays, Tracts, and Addresses, Moral and Religious. By F. W. NEwman. 8vo. Vol. I. 10s, $6 d$. ; Vols. II. and III. 12s. each; Vol. IV. 10s. 6d.; Vol. V. I2s.

Enigmas of Life. By W. R. Greg. Serenteenth Edition. Post 8vo, 10s. 6d. New Edition with Prefatory Memoir, Edited by his Wife. 6s.

[Philosophical Library.

Creed of Christendom, The. By W. R. GREG. Eighth Edition. 2 vols. Post 8vo, 15 s.

[Philosophical Library.

Miscellaneous Essays. By W. R. Greg. Two Series. Crown $820,7 s .6 \%$. each.

Christianity, Essence of, from the German of L. Feuerbach. By Marian Evans. Second Edition. Post 8vo, 7s. 6d.

[Philosophical Library.

Dawn of Death, The. By Luscombe. Searelle. Crown 8vo, 4s. $6 d$. 
Conflict between Religion and Science, The. By J. IV. DRAPER. Tiwenty-first Edition. Crown 8vo, 5 s. [I.S.S.

Analysis of Religious Belief. By Viscount Amberley. 2 vols., 8zo, 3os.

Candid Examination of Theism. By Physicus. Second Edition. Post 8vo, 7s. 6d.

[Philosophical Library.

Counsels and Reflections. By Guicciardini. Translated by N. H. Thomson. Crown Sro, 6s.

Essays on the Philosophy of Theism. By W. G. WARD. Edited, with an Introduction, by WILFRID WARD. 2 vols., 8vo, 2 Is.

Creed of Science, Religious, Moral, and Social. By William Grairam. Second Edition, revised. Crown 8vo, 6s.

Service of Man, The : An Essay towards the Religion of the Future. liy J. Cottrer Morison. Crown 8vo, 5 s.

Religion and Philosophy in Germany. By Herne. Translated by J. Snodgrass. Post Svo, 6s.

[Philosophical Library.

Paul of Tarsus. By the Author of 'Rabbi Jeshua.' Crown $8 v 0,4 s .6 \%$.

Life of Jesus. By ERnest Renan. Crown 8vo, is. $6 d$. Paper covers, is.

The Apostles. By ERnest Renan. Crown 8vo, Is. 6d. Paper covers, is.

Jesus of Nazareth: with a Brief Sketch of Jewish History to the Time of His Birth. By EDward ClodD. Second Edition. Small crown 8vo, 6s. Special Edition for Schools, in 2 parts, Is. $6 d$. each.

Childhood of Religions, including a Simple Account of the Birth and Growth of Myths and Legends. By EDward ClodD. New Edition. Revised, and partly re-written. Crown 8vo, 5 s. Special Edition for schools, is. 62 .

Martyrdom of Man, The. By Winwood READE. Thirteenth Edition. $8 v 0,75.6 \%$.

History of Religion to the Spread of the Universal Religions, Outlines of the. By Prof. C. P. Trisle. Translated from the Dutch by J. Estuin Carpenter. Fourth Edition. I'ost Svo, 7s. 6 d.

[Philosophical Library and Trübner's Oriental Series.

Ten Great Religions. By James Freeman Clarke. An Essay in Comparative Theology. 8vo. Part I. IOs. 6d. Part II. A Comparison of all Religions. 10s. $6 \pi$. 
Blood-Covenant, The: A Primitive Rite, and its Bearing on Scripture. By H. Clay Trumbull. Post 8vo, 7 s. 6d.

Primitive Symbolism as Illustrated in Phallic Worship; or, The Reproductive Principle. By HodDER M. Westropp, with Introduction by Major-Gen. ForLONG. 8vo. 7s. 6d.

Serpent Worship, and other Essays, with a Chapter on Totemism. By C. Staniland Wake. 8vo, ios. $6 d$.

Oriental Religions. See Works on Oriental Subjects.

\section{MYTHOLOGY AND FOLK-LORE.}

Zoological Mythology; or, The Legends of Animals. By ANGELO DE GUBERNATIS. 2 vols. 8vo, £I, 8s.

Mythology of the Aryan Nations. By Rev. Sir George W. Cox, Bart. New Edition. 8vo, i6s.

Comparative Mythology and Folk-Lore, Introduction to the Science of. By Rev. Sir G. W. Cox. Second Edition. Crown 8vo, 7 s. 6 .

Classical Mythology.-Tales of Ancient Greece. By Rev. Sir G: W. Cox. New Edition. Small Crown, 8vo, 6s.

Manual of Mythology in the Form of Question and Answer By Rev. Sir G. W. Cox. Nerw Edition. Fcap. 8vo, 3 s.

Tales of the Gods and Heroes. By Rev. Sir G. W. Cox, Small crown 8vo, 3s. $6 d$.

Mediæval Folk-Lore.-Popular Romances of the Middle Ages. By Rev. Sir G. W. Cox and E. H. Jones. Third Edition. Crown $8 v 0,6 s$.

Greeko-Slavonic Literature and its Relation to the FolkLore of Europe during the Middle Ages. By M. GaSTER, Large Post 8vo, 7s. 6d.

Ethnology in Folk-Lore. By George Laurence Gomme. Crown 8vo, 2s. 6d. [Modern Scièncè Seriès.

Bushman Folk-Lore, Brief Account of. By W. H. I. BLEEK. Folio, 2s. 6d.

Hottentot Folk-Lore.-Reynard the Fox in South Africa; or, Hottentot Fables and Tales. By W. H. I. BLeEk. Post $8 v 0,3$ s. $6 a$. 
Turkish Tales.-The History of the Forty Vezirs; or, The Story of the Forty Morns and Eves. Translated from the Turkish by E. J. W. Gibi. Crowen 8vo, ios. $6 d$.

Eastern Proverbs and Emblems Illustrating Old Truths. By J. Long. Post 8vo, 6s.

[Trübner's Oriental Series.

Indian Mythology.-Vishnu Puráná: A System of Hindu Mythology and Tradition. From the original Sanskrit. Illustrated by Notes derived chiefly from other Puránás. Translated by H. H. Wilson. Edited by Fitz EdWARd Hall. 5 vols. £3, 4s. 6 .

Indian Mythology.-Classical Dictionary of Hindu Mythology and History, Geography, and Literature. By JoHn Dowson. Post 8vo, I6s.

[Trübner's Oriental Series.

Indian Mythology. - Cosmogony, Mythology, etc. of the Indians in the Vedic Age. By John MuIr. Third Edition. £I, Is.

Indian Folk-Lore.-History, Folk-Lore, and Distribution of the Races of the North-Western Provinces of India. By Sir H. M. Elliott. Edited by J. Beames. With 3 coloured Maps. 2 vols. $8 v 0, £ \mathrm{I}, \mathrm{I} 6 s$.

Buddhist Birth-Stories; or, Jataka Tales. The Oldest collection of Folk-Lore extant: being the Jātakatthavannanā. Translated from the Pali text of V. FAusBoll by T. W. Rhys Davids. Post $8 v 0, \mathrm{I} 8$ s.

[Trübner's Oriental Series.

Tibetan Tales, derived from Indian Sources. Done into English from the German of F. Anton von Schiefner. By W. R. S. Ralston. Post 8vo, I4s.

[Trübner's Orlental Series.

Burmese Folk-Lore.-Ancient Proverbs and Maxims from Burmese Sources; or, The Niti Literature of Burma. By J. Gray. Post 8vo, 6s.

[Trübner's Oriental Serles.

Folk Tales of Kashmir. By Rev. J. H. Knowles. Post 8vo, I6s.

[Trübner's Orlental Serles.

Folk Songs of Southern India, containing Canarese, Badaga, Coorg, Tamil, Malayalam, and Telugu Songs. Bv C. E. Gover, $8 v 0$, IOs. $6 d$.

Japanese Fairy World: Stories from the Wonder-lore of Japan. By W. E. Griffis. With 12 Plates. Square I6mo, 3s. $6 d$.

Folk-Lore of China, and its Affinities with that of the Aryan and Semitic Races. By N. B. Dennys. 8vo, ios. $6 d$.

Proverbs and their Lessons. By ARCHBISHOP TRENCH, Seventh Edition, enlarged. Fipa. 8vo, 4 s. 
Mandan Customs.-O-Kee-Pa, A Religious Ceremony; and other customs of the Mandans. By Georgr Catlin. With I3 Coloured Illustrations. Small 4 to, r 4 s.

Oriental Mythology. See Works on Oriental Subjects.

\section{WORKS RELATING TO THE OCCULT SCIENCES, ANIMAL MIAGNETISM, SPIRITISNI, AND THEOSOPHY.}

Hermes Trismegistus, Christian Neoplatonist, Theological and Philosophical Works of. Translated from the Greek by J. D. Chiambress. $8 v o, 7 s .6 d$.

Hermes Trismegistus. The Virgin of the World. Translated and edited by the Authors of 'The Perfect Way.' Illustrations. 4to, imitation parchment, IOs. $6 d$.

The Occult Sciences, A Compendiurn of Transcendental Doctrine and Practice. By A. E. Waite. Crown Svo, 6s.

The Kabbalah Unveiled, containing the Chief Books of the Zohar. Translated by S. L. M. Mathers from the Latin version of 'Rosenroth,' collated with the Chaldee and Hebrew Text. Pos' $8 v 0$, IOs. $6 d$.

Magic, Mysteries of: A Digest of the Writings of Eliphas LÉvi. By A. E. WAite. With Illustrations. 8vo, Ios. $6 d$.

Magic, White and Black; or, The Science of Finite and Infinite Life. By Franz Hartmann. Third Edition. Crown 8vo, 75. $6 d$.

Practical Magic.-The Key of Solomon the King, translated from ancient MSS. in the British Museum. By S. L. M. Matriers. With numerous Plates. Crown 4 to, 25 s.

Alchemy.-Lives of Alchemystical Philosophers, based on matcrials collected in 1815 , and supplemented by recent researches. By A. E. Waite. With a Bibliography of Alchemy. 8vo, 10s. $6 d$.

Astrology.-Spiritual Hermeneutics of Astrology and Holy Writ. Edited by ANNA Kingsford. With Illustrations, 4to, parchment, IOs. 6\%.

Astrology.-The Astrologer's Guide (Anima Astrologia). Edited by W. C. Eldon Serjeant. 8vo, 7s.6d.

Hypnotism, or Animal Magnetism. By Rudolph Heinenhain, with Preface by G. J. Romanes. Second Edition. Small Sio, 2s. $6 \%$ 
Animal Magnetism. By A. Binet and C. Féré. Second Edition. Crown 8vo, 5 s.

[I. S. S.

Phantasms of the Living. By Edmund Gurney, F. W. H. Myers, and F. PODMORE. 2 vols. 8vo, 2Is.

Phantoms.-Posthumous Humanity : A Study of Phantoms, from the French of Adolphe D'Assier, by Colonel OlcotT. With Appendix and Notes. Crown 8vo, 7s. 6d.

The Rationale of Mesmerism. By A. P. Sinnetr. Crown $8 \pi^{\prime}, 3$ s. $6 d$.

Theosophy.-The Occult World. By A. P. Sinnetr. Fifth Edition. Crown 8vo, 3s. 6d.

Theosophy, Religion, and Occult Science. By Colonel OrcotT, With Glossary of Eastern words. Crown 8vo, 7s. 6d.

Theosophy.-Incidents in the Life of Madame Blavatsky. By A. P. Sinnetr. With Portrait. 8vo, ros. $6 d$.

Theosophy.- Light on the Path, for the Personal Use of those who are ignorant of the Eastern Wisdom. Written down by M. C. ficap. 8vo, is. 6d.

Rosicrucians, Real History of the, founded on their own Manifestoes. By A. E. Waite. With Illustrations. Crown 8vo, 7 s. $6 d$.

Mysticism.-The Perfect Way; or, The Finding of Christ. By ANNA KingsFord and EDWARD Martland. Tinird Edition, Revised. Square $16 \mathrm{mo}, 7 \mathrm{~s} .6 \%$

Mysticism, Philosophy of. Translated from the German of Carl du PRel. By C. C. MAssey. 2 vols. 8vo, cloth, 25 s.

Mysticism. - The Way, the Truth, and the Life: A Handbook of Christian Theosophy, Healing, and Psychic Culture. By J. H. Dewey. ros. $6 d$.

Mysticism.-The Pilgrims: An Allegory of the Soul's Progress from the Earthly to the Heavenly State. By Charles Fox. Crown 8vo, 5 s.

Mysticism.-Through the Gates of Gold. A Fragment of Thought. By Mabel Collins. Small 8vo, 4s. 6d.

Oriental Mysticism.-The Indian Religions; or, Results of the Mysterious Buddhism. By Hargrave Jennings. 8vo, ros. $6 d$.

Esoteric Philosophy.-The Hidden Way across the Threshold; or, The Mystery which hath been hidden for ages and from generations. By J. C. STReet. With Plates. Large 8vo, 15 s. 
Geometrical Psychology; or, The Science of Representation. AN abstract of the Theories and Diagrams of B. W. BETTs. By Lorisa S. Cook. Sixteen Plates. 8vo, 7s. 6d.

Reincarnation. The Idea of Re-Birth. By FrancesCA Arundale, with Preface by A. P. Sinnett. Crown 8vo, 4s. $6 \%$.

Paracelsus, Life of, and the Substance of his Teachings. By Franz Hartainn. Post 8vo, ios. 6\%.

Jacob Boehme, Life and Doctrines of: An Introduction to the study of his works. By Franz Hartmann. Post 8vo, 10s. $6 d$.

Thomas Vaughan, Magical Writings of. Edited, with Introduction and Notes. By A. E. WAITE. Small $4 t o$, IOs. $6 d$.

Spiritualism. - Miracles and Modern Spiritualism. By Alfred Russell Wallace. Second Edition. Crown 8vo, 5 s.

Spiritualism.-Footfalls on the Boundary of Another World. With narrative Illustrations, by ROBERT DALE OWEN. Post 8vo, $75.6 d$.

Spiritualism.-Debatable Land between this World and the Next. By ROBERT Dale Owen. With Illustrative narrations. Second Edition. Crown 8vo, 7s. 6d.

Spiritualism.-Threading my Way: Twenty-seven Years of Autobiography. By Robert Dale Owen. Crowen 8vo, 7s. 6d.

Chiromancy.-The Influence of the Stars: A Treatise on Astrology, Chiromancy, and Physiognomy. By Rosa Baughan. $8 v 0,5$ s.

Chiromancy.-Palmistry and its Practical Uses. By LoUISF. Cotton. Twelve Plates. Crown 8vo, 2s. $6 d$.

Fortune-Telling.-The Tarot: Its Occult Signification, Use in Fortune-telling, and Method of Play. By S. L. M. Mathers. With pack of 78 Tarot cards, 5 s. ; without the cards, Is. $6 \mathrm{~d}$.

\section{NUMISMITICS.}

Numismata Orientalia, The. Royal 4to, in Paper Wrapper. Part. I. - Ancient Indian Weights. By E. THOMAS. With a Plate and Map, 95. 6d. Part II.-Coins of the Urtuki Turkumáns. By S. LANE POOLE. With 6 Plates, 9s. Part III.-Coinage of Lydia and Persia. By Barclay V. Head. With 3 Plates, IOS. 6d. Part IV. - Coins of the Tuluni Dynasty. By E. T. Rogers. With I Plate, 5s. Part V.-Parthlan Coinage. By Percy Gardner. With 8 Plates, I8s. Part VI.-Ancient Coins and Measures of Ceylon. By T. W. RHYs Davids. With I Plate, IOS. 
Vol. I. containing the first six parts as specified above. Royal 4to, half-bound, L3 $3_{3} \mathrm{1} 3$ s. 6 \%

Vol. II. Coins of the Jews : being a history of the Jewish coinage in the Old and New Testaments. By F. W. MADDEN. With 279 Woodcuts and Plate. Royal 4to, £2.

Vol. III. Part I.-The Coins of Arakan, of Pegu, and of Burma. By Lieut.-General Sir Arthur Phayre. Also contains the Indian Balhara and the Arabian Intercourse with India in the ninth and following centuries. By EDWARD THOMAs. With 5 Illustrations. Royal 4to, 8s. 6d.

Vol. III. Part II. - The Coins of Southern India. By Sir W. ElliotT. With Map and Plates. Royal 4to, 25s.

Numismata Orientalia. Illustrated. Fifty-seven Plates of Oriental Coins, Ancient and Modern, from the collection of the late William Marsden, F.R.S. Engraved from drawings made under his directions. $4 t o, 3 I s, 6 d$.

\section{GENERAL AND EUROPEAN HISTORY.}

Christian Origins.-The Rise of Christendom. By EDwIN JOHNSON. 8vo, 14 s.

Early Britain.-The Celt, the Roman, and the Saxon: A History of the early inhabitants of Britain down to the conversion of the Anglo-Saxons to Christianity. By Thomas Wright. Corrected and Enlarged Edition. With nearly 300 Engravings. Crown 8vo, 9 s.

The History of Canada. By W. Kingsford. Vol. i. 16081682; vol. ii. 1679-1725; vol. iii. 1726-1756; vol. iv. 1756-1763; vol. v. 1763-1775. With Maps. 8vo, I5s. each volume.

Lectures to American Audiences. By E. A. Freeman. I. The English People in its Three Homes. II. Practical Bearings of General European History. Post 8vo, 8s. 6\%.

The White King ; or, Charles the First, and Men and Women, Life and Manners, etc. in the first half of the seventeenth century. By W. H. DAVEnPoR'T ADAMS. 2 vols. 8vo, 2 Is.

The London Charterhouse : Its Monks and its Martyrs. By DOM LAWR Fnce Hendriks. Illustrated. 8vo, i5s.

Ireland, Short History of. By C. G. Walpole. With 5 Maps and Appendices. Third Edition. Crown 8vo, 6s.

Two Centuries of Irish History. With Introduction by JAS. BRYCE, M.P., 8vo, 16 s. 
Ireland.-Celtic Ireland. By Sophie Bryant. With 3 Maps. Crown 8vo, 5 s.

France and the French in the Second Half of the Nineteenth Century. By KARL Hillebrand. Translated from the third German Edition. Post 8vo, 10s. 6d.

Pope Joan: An Historical Study, from the Greek of Emmanuel Rhoidis. By C. H. Colletete. I2mo, 2s. $6 d$.

Martin Luther and the Reformation in Germany. By Charles Beard. 8vo, i6s.

Reformation.-Lectures and Papers on the History of the Reformation in England and on the Continent. By AUBREY L. MOORE. 8vo, I6s.

South America.-Spanish and Portuguese South America during the Colonial Period. By R. G. Watson. 2 vols. Post $8 v 0,2$ Is.

Egyptian Revolution, History of the, from the Period of the Mamelukes to the death of Mohammed Ali. By A. A. PAtor. Second Edition. 2 vols. 8vo, 7s. 6 .

Trade Guilds.-History and Development of Guilds and the Origin of Trade Unions. By Lujo Brentano. 8vo, 3s. $6 d$.

Tithes, History of, from Abraham to Queen Victoria. By Henry W. Clark. Crown 8vo, 5 s.

Gustavus Adolphus in Germany, and other Lectures on the Thirty Years' War. By ARCHBISHOP TRENCH. Third Edition, enlarged. Fcap. 8vo, 4 s.

Mediæval Church History, Lectures on; being the substance of Lectures delivered at Queen's College, London. By ARCHBISHOP TRENCH. Second Edition. 8vo, $12 s$.

Religious Life of England, Retrospect of the ; or, Church, Puritanism, and Free Inquiry. By J. J. TAyLER. Second Edition. Post 8vo, 7s. 6d.

The Early History of Balliol College. By Frances DE PaRAVicini. 8vo, i2s.

History of St. Martin's Ohurch, Canterbury. By CANoN C. F. Routledge. Crown $8 v 0,5$ s.

The Making of Italy, 1856-1870. By The O'Clery. 8vo, I6s.

The Irish in Britain from the Earliest Times to the Fall and Death of Parnell. By John Denvir. Crown 8vo, 6s.

The Martyrdom of Man. By Winwood Reade. Fourteenth Edition. Crown 8vo, 7s. 6d. 
Popular History of the Mexican People. By K. H. BANCROFT. $8 v 0$, I5s.

Anglo-Jewish History, Sketches of. By James Picciorto. $8 v 0$, I $2 s$.

Scripture History for Jewish Schools and Families, Manual of. By L. B. Abrahams. With Map. Crown 8vo, is. $6 d$.

Blunders and Forgeries: Historical Essays. By T. E. BRIDGETT. Crown 8vo, $6 \mathrm{~s}$.

The Gypsies. By C. G. Leland. Crown 8vo, ios. 6d.

Oriental History. See Works on Oriental Subjects.

\section{TRAVELS, VOYAGES, AND GUIDE-BOOKS.}

Equatorial Africa. The Kilima-Njaro Expedition: A Record of Scientific Exploration in Eastern Equatorial Africa. By H. H. JoHNSTON. With 6 Maps and 80 Illustrations. 8vo, 2Is.

South Africa.-Matabele Land and the Victoria Falls: A Naturalist's wanderings in the interior of South Africa. By FrANK OATES. Edited by C. G. OATES. With numerous Illustrations and 4 Maps. 8vo, 21s.

Zululand.-Cetywayo and his White Neighbours; or, Remarks on Recent Events in Zululand, Natal, and the Transvaal. By H. Rider Haggard. Third Edition. Crown 8vo, 6s.

South America, Around and About: Twenty Months of Quest and Query. By Frank Vincent. With Maps, Plans, and 54 Illustrations. Medium 8vo, 21 s.

Guiana, Among the Indians of: Sketches, chiefly Anthropologic, from the interior of British Guiana. By Everard F. IM THURN. With 53 Illustrations and a Map. 8vo, I8s.

British New Guinea, Toil, Travel, and Discovery in. By TheOdore F. Bevan. With 5 Maps. Large crown 8vo, $7 \mathrm{~s}, 6 d$.

Two Years in a Jungle. by W. T. Hornaday. With Illustrations. $8 v 0,2 \mathrm{I} s$.

History of a Slave. By H. H. Johnston. With Fortyseven Illustrations. Square 8vo, 6s.

Fu-Sang ; or, The Discovery of America by Chinese Buddhist Priests in the fifth century. By C. G. Leland. Crown 8vo, $75.6 d$. 
Kashmir and Kashgar: The Journey of the Embassy to Kashgar in 1873-74. By Surgeon-General H. W. Bellew. $8 v 0$, IOS. $6 d$.

Egypt: Leaves from an Egyptian Note-Book. By Canon IsaAC TAYLOR. Crown 8vo, 5 s.

Egypt as a Winter Resort. By F. M. Sandwith. Crown $8 v 0,35.6 d$.

Japan : Notes of a Tour from Brindisi to Yokohama, I8831884. By Lord Ronald Gower. Fcap. 8vo, 2s. 6d.

Ceylon. - A Visit to Ceylon. By Professor Ernst Haeckel. Post 8vo, 7s. 6d.

Bermuda Islands. By A. Heilprin. 8vo, r8s.

Holy Land, Forty Days in the. By E. H. Mitchell. With 6 Illustrations. Crown 8vo, 6 s.

Bulgaria, Past and Present: Historical, Political, and Descriptive. By James Samuelson. With Map and numerous Illustrations. 8vo, Ios. $6 d$.

H.R.H. The Duke of Clarence and Avondale in Southern India. By J. D. REes. With a narrative of Elephant Catching in Mysore, by G. P. SANDERson. With Map, Portraits, and Illustrations. Medium 8vo, 3Is. $6 d$.

Lord Connemara's Tours in India, 1886-1890. By J. D. ReEs. With Maps. 8vo, I5s.

Buried Cities and Bible Countries. By George St. Clair. Large crown 8vo, 75. $6 d$.

Naples in 1888. By E. N. Rolfe and H. Ingleby. With Illustrations. Crown 8vo, 6s.

Venetian Studies. By Horatio F. Brown. Crown 8vo, 7s. 6d.

Lagoons, Life on the. By H. F. BRown. With 2 Illustrations and Map. Crown 8vo, 6s.

Germany, Present and Past. By S. Baring-Gould. New and cheaper Edition. Large crown 8vo, 75. $6 \%$.

Carlsbad and its Natural Healing Agents. By J. KRAus. With Notes by John T. Wallers. Third Edition. Crown $8 v o, 6 s .6 d$.

The Alps. By Prof. F. Umlauft. Translated by Louisa BroUgh. With II Illustrations. $8 v 0,25$ s. 
B. Bradshaw's Dictionary of Mineral Waters, Climatic Health Resorts, Sea Baths, and Hydropathic Establishments. With Maps and Plans. Crown Svo, 2s. 6d.

Alone through Syria. By Ellen E. Miller. With an Introduction by Prof, A. H. SAYCE. With 8 Jllustrations. Second Edition. Cr. 8vo, 5 s.

Arctic Expedition.-The Great Frozen Sea: A Personal Narrative of the Voyage of the Alert during the Arctic Expedition of 1875-76. By Captain Albert Hastings Markham. With Illustrations and Map. Sixth and cheaper Edition. Crown 8vo, 6s.

North Wales.-Through North Wales with a Knapsack. By

Four Schoolmistresses. With a Sketch Map. Small 8vo, 2s. 6d.

Madeira, Handbook of the Island of. By J. M. RENDELl. With Plan and Map. Second Edition. Ficap. 8vo, Is. 6d.

The Architecture of the Churches of Denmark. By MAJOR Alfred Heales. 8vo, i $4 s$.

\section{BIOGRAPHY.}

St. Anselm, Archbishop of Canterbury and Primate of the Britains, Life and Times of. By Martin Rule. 2 vols., 8ro, $32 s$.

Thomas Becket, Martyr Patriot. By R. A. Thompson. Crown 8vo, 6s.

Thomas Cranmer, D.D., First Reforming Archbishop of Canterbury, Life, Times, and Writings of. By C. H. Colletre. $8 v 0,75.6 d$.

William Laud, sometime Archbishop of Canterbury. By A. C. Benson. Crown 8vo, 6s.

John Henry Newman, the Founder of Modern Anglicanism, and a Cardinal of the Roman Church. By Wilfrid Meyneld. Crowen 8vo, 2s. $6 d$.

John Henry Newman. Contributions chiefly to the Early History of the late Cardinal Newman; By F. W. Newman. Crowen 8vo, 3s. 6 .

Archbishop Trench, Letters and Memorials of. By the Author of 'Charles Lowder.' With 2 Portraits. 2 vols. 8vo, $2 \mathrm{Is}$.

Bishop Wilberforce of Oxford and Winchester, Life of. By his Son. Crown 8vo, 9s.

Antonio Rosmini Serbati, Life of. By Rev. W. Lockhart. With Portraits. 2 vols. crown 8vo, 12s. 
F. W. Robertson, Life and Letters of. Edited by STOPFORD BroOKr.

I. Library Edition, with Portrait. 8vo, I2s.

II. With Portrait. 2 vols. crown 8vo, 7s. 6d.

III. Popular Edition. Crown 8vo, 6 s.

Bishop Selwyn of New Zealand and of Lichfield: A Sketch of His Life and Work, with further gleanings from his Letters, Sermons, and Speeches. By Canon CURTEIS. Large crown 8vo, 7s. 6 \%

Bishop Rawle: A Memoir. By G. Mather and C. J. BLAGG, Large crown 8vo, 7s. 6d.

Bishop Forbes: A Memoir. By Donald J. Mackay. With Portrait and Map. Crown 8vo, 7s. 6\%.

Burke, T. N., Life of the Very Rev. By W. J. Fitzpatrick. With Portrait. 2 vols, $8 v 0,30$ s.

Alexander Heriot Mackonochie: A Memoir. By E. A. T. Edited, with Preface, by E. F. Russell. With Portrait and Views, Large crown 8vo, 7s. 6d. Cheap Edition, crown 8vo, 3s. 6d.

Pope Joan : An Historical Study, from the Greek of RHoidis. Translated by C. H. Collette. I $2 m o, 2 s .6 d$.

William Caxton, England's First Printer, Biography and Topography of. By W. BLADES. Svo, hand-made paper, imitation old bevelled binding, £I, Is. Cheap Edition. Crown 8vo, 5 s.

Francis Bacon, Life and Times of. By JAMES Spedding. 2 vols, post 8vo, $21 \mathrm{~s}$.

Percy Bysshe Shelley, Life of. By Edward Dowden, LL.D. With Portraits. 2 vols. 8vo, 36 s.

In Tennyson Land: A Brief Account of the Home and Early Surroundings of the Poet Laureate. By J. Cuming Walters. With Illustrations. 8vo, 5 s.

Longfellow, Life of By his Brother Samuel Longfellow. With Portraits and Illustrations. 3 vols. $8 v 0,42 s$.

Lord Lytton, Life, Letters, and Literary Remains of Edward Bulwer, Lord Lytton. By the Earl of LytTon. With Portraits, Illustrations, and Facsimiles. 8vo, vols. I. and II., $32 s$.

Ralph Waldo Emerson, Talks with. By C. J. Woodbury. Crown Svo, 5 s.

Emerson at Home and Abroad. By M. D. Conway. With Portrait. Post 8vo; IOs. 6d.

[Phllosophical Library.

George Eliot, Thoughts upon her Life, her Books, and Herself. By Margaret Lonsdale. Second Edition. Small 8vo, Is. $6 d$, 
John Lothrop Motley: A Memoir. By Oliver Wendell Holmes. Crowen 8vo, 6s.

Giordano Bruno, the Nolan, Life of. By I. Frith. Revised by Professor Moriz Carriere. With Portrait. Post 8vo, I4s.

Benedict de Spinoza, Life, Correspondence, and Ethics of. By R. Willis. 8vo, 2 Is.

Thomas a Kempis: Notes of a Visit to the Scenes in which the Life of Thomas à Kempis was spent. By F. R. CRUisE. With numerous Illustrations. Svo, I $2 s$.

Lessing: His Life and Writings. By James Sime. Second Edition. 2 vols. With Portraits. Post 8vo, 21s.

[Philosophical Library.

Edgar Quinet: His Early Life and Writings. By RICHARD Heath. With Portraits, Illustrations, and an Autograph Letter. Post 8vo, 12s. 6d.

[Plidiosophical Líbrary

Johann Gottlieb Fichte, Memoir of. By W. Smith. Second Edition. Post 8vo, 4s.

James Hinton, Life and Letters of. With an Introduction by SIR W. W. GuLL, and Portrait engraved on steel by C. H. JEENS. Sixth Edition. Crown 8vo, 8s. 6d.

Dr. Appleton: His Life and Literary Relics. By J. H. Appleton and A. H. Sayce. Post $8 v o$, 10s. $6 d$.

[Philosophical Library.

Mendelssohn's Letters to Ignaz and Charlotte Moscheles. Translated by FELIX Moscheles. Numerous Illustrations and Facsimiles, 8vo, I2s.

William Charles Macready. By William Archer. Crown $8 v 0,2 s .6 d$.

[Eminent Actors.

Thomas Betterton. By R. W. Lowe. Crozen 8vo, 2s. $6 d$. [Eminent Actors.

Charles Macklin. By Edward Abbott Parry. Crown 8vo, 2s. $6 d$.

[Emlnent Actors.

Charles Dickens and the Stage; or, A Record of his Connection with the Drama. By T. Edgar PEMberton. Crown $8 v 0,6 s$.

John Leech, Artist and Humourist: A Biographical Sketch. By Fred G. KitTon. I8mo, is.

Major-General Sir Thomas Miunro: A Memoir. By Sir A. J. ARBUthNot. Crown 8vo, 3s. 6d. 
Major-General C. G. Gordon, His Journals at Khartoum. Printed from the Original Mss., with Introduction and Notes by A. EgMont HAKe. Portrait, 2 Maps, and 30 Illustrations. 2 vols. 8vo, 2Is. Cheap Edition, 6s.

Gordon's Last Journal: A Facsimile of the Last Journal received in England from GENERAL Gordon. Reproduced by photolithography. Imperial 4 to, $£ 3,3^{s}$.

General Gordon, Events in the Life of, from the Day of his Birth to the Day of his Death. By Sir H. W. Gordon. With Maps and Illustrations. Second Edition. 8vo, 7s. 6d.

Reynell Taylor, C.B., C.S.I. : A Biography. By E. Gambier PARrY. With Portrait and Map. 8vo, 14s.

President Garfield, Life and Public. Services of James A. Garfield, President U. S. A. By Captain F. H. MASON. With a Preface by Bret Harte. Portrait. Crown 8vo, 2s. $6 d$.

Gouverneur Morris: Minister of the United States to France, Diary and Letters of. By ANNe C. Morris. With Portraits. 2 vols. 8vo, 30 s.

Madame de Maintenon. By Emily Bowles. With Portrait. Large crown 8vo, 7s. $6 d$.

Marie Antoinette, Last Days of: An Historical Sketch. By Lord Ronald Gower. With Portrait and Facsimiles. Ficap. 4to, IOS. 6 \%

Rupert of the Rhine: A Biographical Sketch of the Life of Prince Rupert. By LORD RONAld Gowr. With 3 Portraits. Crown 8vo, buckram, 6s.

My Reminiscences. By LORD Ronald Gower. Miniature Edition. Printed on hand-made paper, limp parchment antigue, IOS. $6 \%$.

Paracelsus, Life of, and the Substance of his Teachings. By Franz Hartmann. Post 8vo, Ios. $6 d$.

The Life of Francis Duncan, C.B., R.A., M.P. By Rev. HENRY BIRDWOOD BLOGG. With Introduction by Lord Bishop of Chester. Crown Svo, 3s. $6 d$.

Jacob Boehme, Life and Doctrines of. An Introduction to the Study of his Works. By Franz Martmann. Post 8vo, 10s.6\%.

Robert Dale Owen: Threading my Way: Twenty-seven Years of Autobiography. Crown 8vo, 7s. 6d.

D. D. Home: His Life and Mission. By Mme. Dunglas Home. With Portrait. Svo, Ios.

Madame Blavatsky, Incidents in the Life of. By A. P. Sinnetr. With Portrait. 8vo, Ios. $6 d$. 
Alexander Csoma de Körös, Life and Works of, between I8rg and 1842 . With a short notice of all his Works and Essays, from original documents. By THEODORE Duka. Post Svo, gs.

[Trübner's Orlental Series.

Sister Dora: A Biography. By Margaret Lonsdale. With Portrait. Thirtieth Edition. Small 8vo, 2s. 6d.

Philip Henry Gosse, Life of. By his Son, Enmund Gosse. 3vo, I5s.

Julius and Mary Mohl, Letters and Recollections of. By M. C. M. Simpson. With Portraits and 2 Illustrations. 8vo, r5s.

Charles Lowder: A Biography. By the Author of St. Teresa. Truelfth Edition. With Portrait. Crown 8vo, 3s. 6d.

William Ellis, Founder of the Birkbeck Schools, Life of. By E. Kell Blyth. Second Edition. 8vo, I4s.

Henry Bradshaw : A Memoir. By G. W. Prothero. With Portrait and Facsimile. 8vo, $\mathbf{6} 6$ s.

Memoirs of Arthur Hamilton, B.A., of Trinity College, Cambridge. Crown 8vo, 6s.

Mrs. Gilbert: Autobiography, and other Memorials. Edited by Josiah Gilbert. Fifth Edition. Crown 8vo, 7s. $6 d$.

James Skinner: A Memoir. By the Author of Charles Lowder. With Preface by the Rev. CANON CARTER, and Portrait. Large crown 8vo, 7s. 6d. Cheap Edition. Crown 8vo, 3s. 6d.

Thomas Davis: The Memoirs of an Irish Patriot. By Sir C. Gavan Duffy. 8vo, i2s.

John Mitchel, Life of. By W. Drluon. With Portrait. 2 vols. 8vo, $21 s$.

Thomas Drummond : Life and Letters of Thomas Drummond, Under-Secretary in Ireland, I835-40. By R. BARRY O'BRIEN. $8 v 0,145$.

Life of B. John Juvenal Ancina. By Fr. Charles Henry BOWDEN. 8vo, 9 s.

A Nun : Her Friends and Her Order. Being a Sketch of the Life of Mother Mary Xaveria Fallon. By Katharine Tynan. Crown 8vo, 5 s.

The Last Colonel of the Irish Brigade, Count O'Connell, and Old Irish Life at Home and Abroad, 1745-1833. By Mrs. Morgan J. O'ConNell. 2 vols. 8vo, 25 s.

Diaries of Sir Daniel Gooch, Bart. With an Introductory Notice by Sir Theodore Martin, K.C.B. With 2 Portraits and an Illustration. Crown 8vo, 6s. 
Mrs. Richard Trench, Remains of the late, being Selections from her Journals, Letters, and other papers. Edited by her son, ARChBISHOP TRENCH. Neze and cheaper Edition. With Portraits, $8 v 0,6 s$.

Biographical Sketches. By C. Kegan Paul. Crown 8vo, 7s. $6 d$.

Maria Drummond: A Sketch. Post 8vo, 2s.

Confessio Viatoris. Fcap. 8vo, 2s.

Biographical Lectures. By George Dawson. Edited by GeOrge St. Clatr. Third Edition. Large crown 800, 7s. 6d.

Brave Men's Footsteps: A Book of Example and Anecdote for young people. By the editor of Men who have Risen. Illustrations by C. Doyle. Ninth Edition. Crown 8vo, 2s. 6d.

Well-spent Lives: A Series of Modern Biographies. By Herbert Edmonds. New and cheaper Edition. Crown 8vo, 3s. 6d.

Episodes in the Lives of Men, Women, and Lovers. By Edith Simcox. Crown 8vo, 7s. $6 d$.

From World to Cloister; or, My Novitiate. By 'BERnard.' Crown 8vo, 5 s.

\section{WORKS ON EDUCATION.}

Educational Theories, Introduction to the History of. By Oscar Browning. Second Edition. 3s. 6d. [Education Library.

Education as a Science. By Alex. Bain. Seventh Edition. Crown 8vo, 5 s.

[I. S. S.

Education, Scientific and Technical ; or, How the Inductive Sciences are taught, and how they ought to be taught. By ROBERT Galloway. 8vo, ros. $6 d$.

Industrial Education. By Sir Philip Magnus. 6s.

[Education Library.

The Education of Girls; and The Employment of Women of the Upper Classes educationally considered. By W. B. HODGson. Second Edition. Crowen 8vo, 3s. 6 .

Women and Work: An Essay on the Higher Education of Girls. By Emily Pfeiffer. Crown 8vo, $6 s$.

School Management: Including a General View of the Work of Education, Organisation, and Discipline. By Joserpi Landon. Seventh Edition. Crown 8vo, 6s.

[Education Library. 
Home Education: A course of Lectures to Ladies. By Charlotite M. Mason. Crown 8vo, 3s. $6 \%$.

Old Greek Education. By Professor MahafFy. Second Edition. 3s. 6d.

[Education Library.

Education of the Human Race, from the German of GoTThold Ephraim Lessing. By F. W. Robertson. Ficap. 8vo, 2s. $6 d$.

Public Schools, Our: Eton, Harrow, Winchester, Rugby, Westminster, Marlborough, and the Charterhouse. Crown 8vo, 6 s.

Freedom in Science and Teaching. By Professor ERNsT Haeckel. With a Prefatory Note by Professor T. H. Huxiey. Crown Svo, 5 s.

\section{GREEK AND LATIN CLASSICS, ETC.}

Homer's Miad, Greek Text, with Translation. By J. G. CORDERY. 2 vols. 8vo, 4 s. Cheap Edition (translation only), Crown $8 v 0,5$ s.

IEschylus: The Seven Plays. Translated into English Verse by Professor Lewis CaMprell. Crown 8vo, 7s. 6d.

Sophocles: The Seven Plays. Translated into English Verse by Professor Lewis Campeell. Crown 8vo, 7s. $6 \pi$.

Horatius Flaccus, Q., Opera. Edited by F. A. Cornish. With Frontispiece. Elzevir Svo (Parchment Library), vellum, 7s. 6it.; parchment or cloth, 6 s.

Pling. The Letters of Pliny the Younger. Translated by J. D. LEwis. Post 8vo, 15 s.

Livy. Discourses on the First Decade of Titus Livius. From the Italian of Niccolo Machiavelli. By N. Hill THOMP. soN. Large crown 8vo, $12 s$.

Philological Introduction to Greek and Latin for Students. Translated and adapted from the German by C. Kegan PAUL and E. D. Stone. Third Edition. Crown 8vo, 6s.

Plutarch: His Life, his Lives, and his Morals. By ArchBISHOp TRENCH. Second Edition enlarged. Fcap. 8vo, 3s. $6 d$.

\section{WORKS ON MILITARY SCIENCE.}

Tactics-Elements of Modern Tactics, practically applied to English Formations. By Lieut.-Col. Wilkinson Shaw. Seventh Edition. With 3 I Plates and Maps. Small crown 8vo, 9s. 
Notes on Military Surveying and Reconnaissance. By Lieut-Col. W. Paterson. With i6 Plates. 8vo, $7 \mathrm{~s} .6 d$.

Tactics.-Minor Tactics. By Gen. C. Francis Clery. With. 26 Maps and Plans. Eleventh Edition, revised. Croown 8vo, 9s.

Field Artillery: Its Equipment, Organisation, and Tactics. By Lieut. - Colonel PratT. Fourth Edition. Small crown 8vo, 6s.

Field Works: Their Technical Construction and Tactical Application. By Major-General Brackenbury, 2 vols. Small crown 8vo, I $2 s$.

Field Training, System of. By Major C. K. Brooke. Small crown 8vo, cloth limp, 2s.

Cavalry in Modern War. By Major-General Trench. Small crown Svo, 6s.

Cavalry Tactics, Organisation, etc., Notes on. By a Cavalry OfFICRr. With Diagrams. 8vo, I2s.

Defence and Attack of Positions and Localities. By Col. H. Schaw. Fourth Edition. Crown 8vo, 3s. 6d.

Military Law: Its Procedure and Practice. By Lieut.Col. Pratt. Seventh Revised Edition. Small crown 8vo, 4s. 6d.

Military Administration, Elements of. By Major Buxton. First Part: Permanent System of Administration. Small crown $8 v 0,7 s .6 d$.

Military Tribunals. By Lieut.-Col. C. F. Colvile. Crown $8 v 0$, sewed, $2 s .6 \%$.

Military Sketching and Reconnaissance. By Col. HutchinSON and Major MACGREgor. Fifth Edition. With 16 Plates. Small crown 8vo, 4s.

Modern War. Translated by C. W. Foster. Part I. Strategy, and Atlas of 64 Plates. 3vo, £I, I6s. Part II. Grand Tactics, I 5 s.

Officer's Memorandum Book for Peace and War. By Col. R. ilarrison. Fourth Edition, revised. Oblong $32 \mathrm{mo}$, red basil, with pencil, 3s. $6 \%$.

Preliminary Tactics. An Introduction to the Study of War. For the use of Junior Officers. By MAJOR EDEN BAKER, R.A. Crowen Sio, 6s.

Tactical Questions and Answers on the Infantry Drill Book, 1892. Compiled by Captain H. R. Gall. Third Edition. Crown Svo, Is. $6 d$.

The British Army and our Defensive Position in 1892. Founded on Speeches and Memoranda and on Parliamentary Papers and Returns. With a Preface by the Right Hon. E. STANiope, M.P., Secretary of State for War. Crown Svo, Is. 


\section{BOTANY AND NATURAL HISTORY.}

Origin of Floral Structures through Insect and other Agencies. By Professor G. Henslow. With 88 Illustrations. Crown Svo, 5 s.

[I. S. S.

Origin of Cultivated Plants. By Alphonse de Candolle. Second Edition. Crown 8vo, 5 s.

[I. S. S.

British Discomycetes, Manual of. With Descriptions of all the Species of Fungi hitherto found in Britain included in the family, and with Illustrations of the Genera. By W. PhILlips. Crown $8 v 0,5 s$.

[I. S. S.

Fungi: their Nature, Influences, and Uses. By M. C. COOKE. Edited by M. J. BERKELEY. With numerous Illustrations. Fourth Edition. Crown 8vo, 5 s.

[I. S. S.

British Edible Fungi ; How to Distinguish and How to Cook Them. With Coloured Figures of upwards of Forty Species. Crown $8 v 0,7 s .6 d$.

Fresh Water Algæ, Introduction to. With an Enumeration of all the British Species. By M. C. Cooke. With I3 Plates. Crown 8vo, 5 s.

[I. S. S.

Botany, First Book of. Designed to Cultivate the Observing Powers of Children. By Eliza A. Youmans. With 300 Illustrations. New and cheaper Edition. Crown 8vo, 2s. $6 d$.

The Oak: A Popular Introduction to Forest Botany. By H. Marshall Ward. Crown Svo, 2s. 6d. (Modern Science Series.)

Rambles and Adventures of our School Field Club. By G. Christopher Davies. With 4 Illustrations. New and cheaper Edition. Crown 8vo, 3s. 6d.

Horny Sponges, Monograph of the. By R. voN LENDENFELD. With 50 Plates. Issued by direction of the Royal Society. 4 to, £3.

Microbes, Ferments, and Moulds. By E. L. Trouessart. With 107 Illustrations. 5 s.

[I. S. S.

The Crayfish: An Introduction to the Study of Zoology. By Professor T. H. Huxley. With 82 Illustrations. Fifth Edition. Crown 8vo, 5 s.

[I. S. S.

History of Creation, The. By Professor ERnst Hacckel. Translation revised by Professor E. RAY LANkester. With Coloured Plates and Genealogical Trees of the various groups of both Plants and Animals. Third Edition. 2 vols. post 8vo, 32 s.

Jelly-Fish, Star-Fish, and Sea-Urchins: Being a Research on Primitive Nervous Systems. By G. J. Romanes. With Illustrations. Second Edition. Crown 8vo, 5 s. 
The Horse: A Study in Natural History. By W. H. FLower. Crown Sivo, 2s. 6d. (Modern Science Series.)

Mental Evolution in Animals. By G. J. Romanes. With Posthumous Essay on Instinct by Charles Darwin. 8vo, i $2 s$.

Animal Intelligence. By G. J. Romanes. Fourth Edition. Crown 8vo, 5 s.

[I. S .S.

Descent and Darwinism, Doctrine of. By Professor O. Schmidr. With 26 Illustrations. Seventh Edition. Crowen 8vo, 5 s.

[l. S. S.

Mammalia in their Relation to Primeval Times. By O. SCHMIDT. With 5 I Woodcuts. Crown 8vo, 5s. [I. S. S.

Senses, Instincts, and Intelligence of Animals. With special reference to Insects. By Sir JoHn Luввоск. With 100 Illustrations. Third Edition. Crown 8vo, 5 s.
[I. S. S.

Ants, Bees, and Wasps: A Record of Observations on the Habits of the Social Hymenoptera. By Sir J. LuBBock. With 5 Chromo-lithographic Illustrations. Tenth Edition. Crown 8vo, 5 s.

[I. S. S.

Geographical and Geological Distribution of Animals. By Professor A. Heillprin. With Frontispiece. 5 s.

[I. S. S.

Natural Conditions of Existence as they affect Animal Life. By Karl Semper. With 2 Maps and 106 Woodcuts. Third Edition. Crown 8vo, 5 s.

[I. S. S.

Colours of Animals : their Meaning and Use, especially considered in the case of Insects. By E. B. Poulton. With Coloured Frontispiece and 66 Illustrations in text. Crown 8vo, 5s. [I. S. S.

Animal Parasites and Messmates. By P. J. van Beneden. With 83 Illustrations. Fourth Edition. Crown 8vo, 5s. [I. S. S.

Anthropoid Apes. By R. Hartmann. With 63 Illustrations. Crown Svo. Second Edition. 5s.
[I. S. S.

Birds of Cornwall and the Scilly Islands. By E. H. RodD. Edited by J. E. Har'TING. With Portrait and Map. Svo, I4s.

South African Butternies: A Monograph of the Extra Tropical Species. By Roland Trimin. With iz Coloured P'lates. 3 vols. 8vo, £2, I2s. 6 d.

Taxidermy and Zoological Collecting. By W. T. HorxadAY. With Chapters on Collecting and Preserving Insects, by W. J. IIOLLAND, D. D. With 24 Plates and S5 Illustrations. Svo, IOs. 6\%. 
Ostriches and Ostrich Farming. By J. DE Mosenthal and James E. Harting. Second Edition. With 8 Full-page Illustrations and 20 Woodcuts. Royal 8vo, IOs. $6 d$.

Australian Birds. - Tabular List of all the Australian Birds at present known to the Author. By E. P. Ramsay. Crown 4to, I2s. $6 d$.

\section{ANTHROPOLOGY.}

Evolution of Man, Fistory of the. By Professor ERNST HAECKEL. With numerous Illustrations. 2 vols. post 8vo, $32 s$.

Evolution in Man, Mental: Origin of the Human Faculty. By G. J. Romanes. 8vo, I 4 s.

Origin of Human Reason. By St. George Mivart. 8vo, IOS. $6 \%$.

Development of the Fuman Race, Contributions to the History of the. Translated from the German of LAzARUS Geigrk by D. Asher. Post 8vo, 6s.

[Philosophical Library.

The Human Species. By Professor A. DE Quatrefages. Fifth Edition. Crown 8vo, 5 s.

[I. S. S.

Primitive Family, The : Its Origin and Development. By C. N. Starcke. Crown Suo, 5 s.

[I. S. S.

Man before Metals. By N. JoLy. With 148 Illustrations. Fourth Edition. Crown Svo, 5 s.

[I. \$. S.

Australian Race, The. Its Origin, Languages, Customs, etc. With Map and Illustrations. By Edward M. CuRR. 3 vols. $8 v o, r$ vol. 4 to, $£ 2,2 s$.

Aborigines of Victoria, The. By R. Brough Smith. Compiled for the Government. With Maps, Plates, and Woodcuts. 2 vols. Royal 8vo, £3, 3 s.

Polynesian Race, Account of the : Its Origin and Migrations, and the Ancient History of the Hawaiian people. By A. ForNANDER. Post 8vo. Vol. I. 7s. 6d.; Vol. II. IOs. 6d.; Vol. III. gs.

[Philosophical Library.

The Ice Age in North America, and its bearing upon the Antiquity of Man. By G. Frederick Wright, D.D. With Maps and Illustrations. $8 v 0,2 \mathrm{Is}$.

Childhood of the World: A Simple Account of Man in Early Times. By EDWARI CLODD. Eighth Edition. Crown 870, 3s. Special Edition for Schools, Is. 
Nature and Man. By W. B. Carpenter. With a Memorial Sketch by J. Estlin Carpenter. Portrait. Large crown 8vo, 8s. 6d.

Five Senses of Man, The. By Professor Bernstein. With 9r Illustrations. Fifth Edition. Crown 8vo, 5 s. [I. S. S.

Physical Expression : Its Modes and Principles. By Professor F. WARNER. With 50 Illustrations. Crozun $8 v 0,5 \mathrm{~s}$.

[I. S. S.

\section{PHYSIOLOGY AND MEDICINE.}

Nental Physiology, Principles of. With their Applications to the Training and Discipline of the Mind, and the study of its Morbid Conditions. By W. B. CARPEnTER. Illustrated. Sixth Edition. 8vo, I2s.

Bodily Exercise, Physiology of. By F. Lagrange. Second Edition. Crown 8vo, 5 s.

[I. S. S.

Muscles and Nerves, General Physiology of. By Professor J. Rosenthal. Third Edition. With 75 Illustrations. Crown $8 v 0,5 s$.

[I. S. S.

Physiological and Pathological Chemistry, Text-Book of, for Physicians and Students. Translated from the German of Professor G. Bunge. By L. C. Wooldridge. 8ro, i6s.

Surgical Handicraft: A Manual of Surgical Manipulations. By PYE. With 233 Illustrations. Third Edition revised. Crown Svo, 10s. $6 \%$.

Bandaging and Surgical Dressing, Elementary, for the use of Dressers and Nurses. By Pye. 18mo, $2 s$.

General Nursing, Lectures on, delivered to the Probationers of the London Hospital Training School for Nurses. By Eva C. E. LüCKes. Third Edition. Crown 8vo, 2s. 6d.

Epidemics of the Middle Ages, The. Translated from the German of J. F. C. Hecker. By G. B. Baimington. Third Edition. 8vo, 9s. 6d.

Colour Blindness and Colour Perception. By F. W. Edridge Green. With 3 Coloured Plates. Crown 8vo, 5 s.

[I. S. S.

Nervous Exhaustion: its Causes, Outcomes, and Treatment. By Walter TYrRill. Crown $8 v o, 3$ s.

Ophthalmoscope, How to use the. By EdGar A. BrownF. Third Edition. Crowen 8vo, 3s. 6d. 


\section{MENTAL AND MORAL SCIENCE.}

Mind and Body: The Theories of their Relations. By Alexander Barn. With Four Illustrations. Eighth Edition. Crown 8vo, 5 s.

[I. S. S.

Brain and its Functions, The: By J. Luys. With Illustrations. Third Edition. Crown 8vo, 5 s.

[I. S. S.

Body and Will: An Essay concerning Will, in its Metaphysical, Physiological, and Pathological Aspects. By H. MAUDSLEY. 8vo, I2s.

Mental Disease, Responsibility in. By H. Maudsley. Fourth Edition. Crown Svo, 5 s.

[I. S. S.

Supernaturalism.-Natural Causes and Supernatural Seemings. By H. Maudslex. Second Edition. Crown 8vo, 6 s.

Diseases of Memory: An Essay in the Positive Psychology. By Professor Th. Ribot. Third Edition. Crown 8vo, 5s. [I. S. S.

Heredity: A Psychological Study of its Phenomena, Laws, Causes, and Consequences. By Professor TH. RiBot. Second Edition. Large crown 8vo, 9s.

English Psychology. By Professor Ribot. Crown 8vo, 7s. 6d.

Brain as an Organ of Mind. By H. Charlton Bastian. With numerous Illustrations. Fourth Edition. Crown 8vo, 5 s.

[I. S. S.

Illusions: A Psychological Study. By Tames Sully. Third Edition. Crown Svo, 5 s.

[I. S. S.

Colour Sense: Its Origin and Development. An Essay in Comparative Psychology. By Grant Allen. Second Edition. Post 8vo, IOs. 6d.

[Philosophical Library.

Ethics.-The Nicomachean Ethics of Aristotle. Translated by F. H. Peters. Third Edition. Crown 8vo, 6s.

Ethics.-Froebel's Ethical Teaching: Two Essays. By M. J. Lyschinska and T. G. Mon'tefiore. Fcap. 8vo, 2s. $6 \%$.

Fthics.-Moral Order and Progress: An Analysis of Ethical Conceptions. By S. Alexander. Post 8vo, r 4 s.

[Philosophical Library.

Ethics.-Principles of Natural and Supernatural Morals. By H. Hughes. Vol. I. Natural Morals. 8vo, I2s.

Logic, The Principles of. By F. H. Bradley. 8vo, i6s. 
Fallacies: A View of Logic from the Practical Side. By A. Srdawick. Second Edition. Crown 8vo, 5 s.

[I. S. S.

Thought.-Natural History of Thought in its Practical Aspect, from its Origin in Infancy. By George Wall. 8vo, i2s. $6 d$.

Suicide: An Essay on Comparative Moral Statistics. By Professor H. MoRselli. Second Edition. With Diagrams. Crown $8 v 0,5$ s.

[I. S. S.

\section{LAW, POLITICS, AND SOCIOLOGY.}

Roman Law.- History and Principles of the Civil Law of Rome: An Aid to the Study of Scientific and Comparative Jurisprudence. By Professor Sheldon Amos. 8vo, i6s.

Science of Law. By Professor Sheldon Amos. Seventh Edition. Crown 8vo, 5 s.

[I. S. S.

Legislation, Theory of, as enunciated by Jeremy Bentham. Translated from the French of ETIENNE. Dumont by R. HildReth. Fifth Edition. Post 8vo, 7s. 6d.

International Law, with Materials for a Code of International Law. By Professor Leone Levi. Crown 8vo, 5 s.

[I. S. S.

International Code, Outlines of an. By D. D. Field. Second Edition. Royal 8vo, £2, 2s.

Architect's Legal Handbook. By E. Jenkins and J. RAYMOND. Fourth Edition, revised. Crown 8vo, 6s.

Politics, Science of. By Professor SHeldon Amos. Third Edition. Crown 8vo, 5 s.

[I. S. S.

Politics, Manual of. By G. G. LEe. Small crozen 8vo, 2s. $6 d$.

Political Problems for our Age and Country. By W. R. Greg. 8vo, IOs. $6 d$.

Physics and Politics; or, The Application of the Principles of 'Natural Selection' and 'Inheritance' to Political Society. By Walter Bagehot. Eighth Edition. Crown 8vo, 5s. [I. S. S.

The Statesman. By Sir H. Taylor. Ficap. 8vo, 3s. 6d.

My Lawyer; or, the People's Legal Adviser. A Concise Abridgment of, and Popular Guide to, the Laws of England. By a Barrister-at-Law. Second Edition. Crown 8vo, 6s. 6d.

Trade Marks; their Registration and Protection. By J. S. Salaman. Crown 8vo, 5 s. 
The Modern Factory System. By R. Whateley Cooke TAYlor. $8 v 0,14 s$.

Government, The Sphere and Duties of. By Baron W. von Humboldt, from the German by J. Coulthard. Post $8 v o, 5 s$.

Home Rule, Handbook of: Being Articles on the Irish Question. By J. Bryce. Second Edition. Crown 8vo, rs. 6d.; paper covers, Is.

Home Ruler's Manual. By R. Barry O'Brien. Crozen 8vo, cloth, Is. $6 d$; ; paper covers, is.

Irish Wrongs and English Remedies, with other Essays. By R. B. O'Brien. Crown 8vo, 5 s.

Irish Members and English Gaolers. By the Right Hon. G. Shaw Lefevre. Crown 8vo, cloth, is. 6d.; paper covers, is.

Coercion, Incidents of: A Journal of Visits to Ireland. Third Edition. Crown 8vo, limp cloth, rs. 6d.; paper, is. By the Right Hon. G. Shaw Lefevre.

Coercion.-Combination and Coercion in Ireland. Sequel to 'Incidents of Coercion.' By the Right Hon. G. Shaw Lefevre. Crown 8vo, cloth, Is. 6d.; paper covers, Is.

Peel and O'Connell. By the Right Hon. G. Shaw Lefevre. $8 v 0$, Ios. $6 d$.

Special Commission, Speech before the. By Michael DavitT. Crown 8vo, 5 s.

Parliamentary Reform, Essays on. By Walter Bagehot. Crown 8vo, 5 s.

English Constitution, The. By Walter Bagenot. Fifth Edition. Crown 8vo, 7s. 6 d.

Lombard Street: A Description of the Money Market. By Walter Bagehot. Ninth Edition. Crowen 8vo, 7s. 6d.

Depreciation of Silver, On the, and Topics connected with it. By Walter Bagehot. 8vo, 5 s.

Money and the Mechanism of Exchange. By W. S. Jevons, Eighth Edition. Crown 8vo, 5 s.

[I. S. S.

Study of Sociology. By Herbert Spencer. Fourteenth Edition. Crowen 8vo, 5 s.

[I. S. S.

Socialism: Its Nature, its Dangers, and its Remedies considered. By M. Kaufmann. Crown 8vo, 7s.6 $d$.

Christian Socialism. By M. Kaufmann. Crozen 8vo, 4s. 6d. 
Utopias; or, Schemes of Social Improvement, from Sir Thomas More to Karl Marx. By M. KaUfMann. Crown Svo, 5 s.

Scientific Meliorism, and the Evolution of Happiness. By Jane H. Clapperton. Large crown 8vo, 8s. $6 d$.

Socialism New and old. By William Graham. Crown $8 v 0,5 s$.

[I. S. S.

The Social Problem, in its Economic, Moral, and Political Aspects. By William Grainam. 8vo, I4s.

What Social Classes Owe to each Other. By W. G. SUMNER. I8mo, 3s. $6 d$.

Capital and Wages. By Francis Minton. 8vo, i 5 s.

Welfare of the Millions. By Francis Minton. Crown $8 v o$, limp cloth, Is. $6 d$. ; paper covers, Is.

Work Amongst Working Men. By Eldice Hopkins. Sixth Edition. Crown 8vo, 3s. 6d.

Principles of Political Economy. By Arthur Latham Perry. Large post 8vo, 9s.

Social Problems. By Henry George. Fourth Thousand. Crown 8vo, 5s. Cheap Edition, limp cloth, Is. 6d.; paper covers, Is.

Progress and Poverty: An Inquiry into the Causes of Industrial Depressions, and of Increase of Want with Increase of Wealth; the Remedy. By Henry George. Fifth Edition. Post 8vo, 7s. 6d. Cabinet Edition, crown 8vo, 2s. 6d. Cheap Edition, limp cloth, Is. 6d.; paper covers, Is.

Protection or Free Trade: An Examination of the Tariff Question, with especial regard to the Interests of Labour. By HENRY George. Second Edition. Crown 8vo, 5s. Cheap Edition, limp cloth, Is. 6d.; paper covers, Is.

Trade Unions: Their Origin, Objects, and Efficacy. By William Trant. Small 8vo, Is. 6d.; paper covers, is.

Marriage and Divorce, including the Religious, Practical, and Political Aspects of the Question. By Ap. Richard. Croun Svo, 5 s.

Marriage and Kinship, Development of. By C. Staniland WAKE. $8 v o$, I8s.

Marriage and Disease: A Study of Heredity and the more important Family Degenerations. By S. A. K. Strahan. Crown $8 v 0,6 s$.

The Distribution of the Produce. By James C. Smith. Crown 8vo, 25. 6d. 


\section{WORKS ON THE PHYSICAL SCIENCES, MINERALOGY, GEOLOGY, ETC.}

Modern Physics, Concepts and Theories of. By J. B. Stallo. Third Edition. Crown 8vo, 5 s.

Exact Sciences, Common Sense of the. By W. K. Clifford. Second Edition. With 100 Figures. Crown 8vo, 5s. [I. S. S.

Atomic Theory, The. By Professor WuRTz. Translated by E. Cleminshaw. Fifth Edition. Crown 8vo, 5 s. [II. S. S.

Conservation of Energy. By Balfour Stewart. With I4 Illustrations. Seventh Edition. Crown 8vo, 5 s. [I. S. S.

Electricity, The Modern Applications of. By E. HosPITALIER. Translated and enlarged by Julius MaIer, Ph.D. Second Edition, revised, with many additions and numerous Illustrations. 2 vols. $8 v 0,25$ s.

The Telephone, the Microphone, and the Phonograph. By Count Do MONCEL. With 74 Illustrations. Third Edition. Small 8vo, 5 s.

Electricity in Daily Life : A Popular Account of its Application to Every day Uses. With 125 Illustrations. Square 8vo, 95.

Chemistry of the Carbon Compounds ; or, Organic Chemistry. By Professor Victor voN Richter. Authorised Translation by EDGAR F. SMith. Second American Edition from Sixth German Edition. Crown 8vo, 20.s.

Text-Book of Inorganic Chemistry. By Professor VICToR vON Richter. Authorised Translation by EDGar F. SMith. Third American Edition from Fifth German Edition. Crown 8vo, 8s. 6d.

Chemistry.-Text-Book of Organic Chemistry. By ADOLPH Strecker. Edited by Professor Wislicenus. Translated and edited, with extensive additions, by W. R. HodGKINSON and A. J. GreENAWAy. Second and cheaper Edition. 8vo, I2s.6d.

Chemistry of Light and Photography. By Dr. Hermann VoGel. With roo Illustrations. Fifth Edition. Crown $8 v 0,5 \mathrm{~s}$.

[I. S. S.

New Chemistry. By Professor J. P. Cookr. With 3I Illustrations. Ninth Edition. Crown 8vo, 5s. [I. S. S.

Laboratory Practice: A Series of Experiments on the Fundamental Principles of Chemistry. By Professor J. P. Conke. Crown $8 v 0,5$ s. 
Meteorology.-Weather : A Popular Exposition of the Nature of Weather Changes from Day to Day. By the Hon. Ralph ABERCROMBY. With 96 Illustrations. Second Edition. Crown $8 v 0,5$ s.

[I. S. S.

Meteorology, Elementary. By Robert H. Scotr. Fourth Edition. With numerous Illustrations. Crown $8 v 0,5$ s.
[I. S. S.

The Sun. By Professor Young. With Illustrations. Third Edition. Crown 8vo, 5 s.

[I. S. S.

Colour: A Text-Book of Modern Chromatics. By OgDen N. ROOD. With 130 Original Illustrations. Third Edition. Crown $8 v 0,5$ s.

[I. S. S.

Spectrum Analysis, Studies in. By J. Norman Lockyer. With Six Photographic Illustrations of Spectra, and numerous Engravings on Wood. Fourth Edition. Crown 8vo, 6s. 6d. [I. S. S.
[

Light, Nature of. By Dr. Eugene Lommel. With a General Account of Physical Optics. 188 Illustrations, and a Table of Spectra in Chromo-lithography. Fifth Edition. Crown 8vo, 5 s.

[I. S. S.

Sight: An Exposition of the Principles of Monocular and Binocular Vision. By Joseph Lr Conte. Second Edition. With 132 Illustrations. Crowen 8vo, 5 s.

[1. S. S.

Organs of Speech and their Application in the Formation of Articulate sounds. By G. Hermann von Meyer. With 47 Woodcuts. Crown 8vo, 5 s.

[I. S. S.

Forms of Water in Clouds and Rivers, Ice and Glaciers. By Professor J. Tyndall. With 25 Illustrations. Ninth Edition. Crown 8vo, 5 s.

[I. S. S.

Animal Mechanism : A Treatise on Terrestrial and Aërial Locomotion. By Professor E. J. MAREY. With II Illustrations. Third Edition. Crown 8vo, 5 s.

[I. S. S.

Animal Locomotion; or, Walking, Swimming, and Flying. By J. B. PeTrigrew. With 130 Illustrations. Third Edition. Crown 8vo, 5 s.

[I. S. S.

Astronomy and Geology, Untrodden Ground in. By MajorGeneral Drayson. With numerous Figures. 8vo, i 45.

Geology.-Text Book of Geology for Schools. By James D. Dana. Illustrated. Crown 8vo, ios.

Geology, Manual of. By James D. DAnA. Illustrated by a Chart of the World and over 1000 Figures. 8vo, $21 s$.

Geology.-The Geological Story briefly told. By James D.

DANA. Iilustrated. $12 m 0,75.5 d$. 
Geological History of Plants. By Sir J. W. DAwson. With So Figures. Crown Svo, 5 s.

[I. S. S.

Earthquakes and other Earth Movements. By Professor J. Milnz. With 38 Figures. Second Edition. Crown 8vo,5s. [I. S. S.

The Cause of an Ice Age. By Sir Robert Ball. Second Edition. Crown 8vo, 2s. 6d.

[Modern Science Series.

Ice Age, The, in North America, and its Bearing upon the Antiquity of Man. By G. Frederick Wright. With Maps and Illustrations. 8vo, 2Is.

Volcanoes, What they Are and What they Teach. By Professor J. W. JUDD. With 96 Illustrations on wood. Fourth Edition. Crown 8vo, 5 s.

[I. S. S.

Volcanoes.-The Eruption of Krakatoa, and Subsequent Phenomena : Report of the Krakatoa Committee of the Royal Society. By G. J. Symons. With 6 Chromo-lithographs and 40 Maps and Diagrams. 4to, £I, IOs.

Valleys and their Relations to Fissures, Fractures, and Faults. By G. H. Kinahan. Crown 8vo, $75.6 d$.

America.-The Lifted and Subsided Rocks of America. with their influence on the Oceanic, Atmospheric, and Land Currents, and the Distribution of Races. By George CATLIN. With 2 Maps. Crown 8vo, 6s. 6d.

Madagascar, The Great African Island: Its Physical Geography, etc. By JAMES SiBREE. With Maps and Illustrations. $8 v 0$, ros. $6 d$.

Physical History of the Earth, Chapters from: An Introduction to Geology and Palæontology. By Artiun Nichols. With numerous Illustrations. Crown 8vo, 5 s.

The Powers which Propel and Guide the Planets. With Comments. By Sydney Laidlaw. Crozen 8vo, 3s. $6 d$.

Saturn's Kingdom; or, Fable and Fact. By C. Moore JEssop. Crown 8vo, 6s.

Mineralogy, System of. By J. D. Dana and G. J. Brush. Sixtin Edition entirely rewritten and cnlarged by EDWARD Salisbury Dana. Royal 8vo, £3, 3 s.

Mineralogy and Petrography, Manual of. By J. D. DANA and G. J. BRUsh. Fourth Edition. Numerous Woodcuts. Crown $8 v 0,8 s .6 d$.

Mineralogy, Text Book of. With Treatise on Crystallography and Physical Mineralogy. By E. S. DANA. Third Fidition. With Soo Woodcuts and Plates. $8 v 0,15 s$. 


\section{TECHNOLOGY.}

Technological Dictionary of the Terms employed in the Arts and Sciences (Architecture, Engineering, Mechanics, Shipbuilding and Navigation, Metallurgy, Mathematics, etc.). By KarL KaMARSCH. Fourth Revised Edition. 3 vols. imperial Svo.

. Vol. I. German-English-French. I2s.

Vol. II. English-German-French. I2s.

Vol. III. French-German-English. I5s.

Technological Dictionary in the English and German Languages. By Gustav EGER. 2 vols. royal 8vo, £, $7 s$.

Theoretical Mechanics: A Manual of the Mechanics of Engineering. Designed as a Text-book for Technical Schools, and for the use of Engineers. From the German of Julius Weisbach. By E. B. Coxe. With 902 Woodcuts. 8vo, 3Is. 6d.

Amateur Mechanic's Workshop: Plain and Concise Directions for the Manipulation of Wood and Metals. By the Author of 'The Lathe and its Uses.' Sixth Edition. Illustrated. Svo, 6s.

Lathe, The, and its Uses; or, Instruction in the Art of Turning Wood and Metal. Sixth Edition. Illustrated. 8vo, ros.6d.

Mechanic's Friend, The: A collection of Receipts and Practical Suggestions relating to Aquaria, Bronzing, Cements, Drawing, Dyes, Electricity, Gilding, Glass-working, etc. By. W. E. A. AxON. Second Edition. Numerous Woodcuts. Crown 8vo, 3s. 6d.

Amongst Machines: A Description of Various Mechanical Appliances used in the Manufacture of Wood, Metal, etc. A book for boys. By J. Lukin. Third Edition. With 64 Engravings. Crown Svo, 3s. 6d.

Boy Engineers, The: What They Did, and How They did it. A book for boys. By J. Lukin. With 30 Engravings. Third Edition. Crown 8vo, 3s. 6d.

Young Mechanic, The: A Book for Boys, containing Directions for the Use of all kinds of Tools, and for the Construction of Steam Engines and Mechanical Models. By J. Lukin. Seventh Edition. With 70 Engravings. Crown 8vo, 3s. $6 d$.

Manual of the Steam Engine. For Engineers and Technical Schools. Parts I. and II. By Professor R. H. Thurston. Koyal Svo, 3is. 6d. each Part.

Steam Engine, History of the Growth of the. By Professor R. H. THu Rston. With numerous Illustrations. Fourth Edition. Crown Svo, 5 s.

[I. S. S. 
Hydraulics: The Flow of Water through Orifices, over Weirs, and through Open Conduits and Pipes. By Hamilton Smitr. With in Plates. Royal quarto, 30 s.

Fuel, Treatise on, Scientific and Practical. By ROBERT Galloway. With Illustrations. Post 8vo, 6s.

Telegraphy.-Instructions for Testing Telegraph Lines. By LOUIS SCHWENDLER. 2 vols. 8vo, $2 \mathrm{Is}$.

Nautical Tables: Designed for the Use of British Seamen. By James Inman. New Edition, Revised and Enlarged. Svo, r6s.

Domestic Sanitary Drainage and Plumbing. By W. R. MAGUIRI. 8vo, I2s.

Milk Analysis: A Practical Treatise on the Examination of Milk and its Derivatives, Cream, Butter, and Cheese. By J. A. Wanklyn. Second Edition. Crown 8vo, 5 s.

Tea, Coffee, and Cocoa: A Practical Treatise on the Analysis of Tea, Coffee, Cocoa, Chocolate, and Maté (Paraguay tea). By J. A. Wankiyn. Crown $3 v 0,5^{\text {s. }}$

Bread Analysis: A Practical Treatise on the Examination of Flour and Bread. By J. A. WANkLYN and W. J. Cooper. Crown 8vo, 5 s.

Air Analysis: A Practical Treatise, with Appendix on Illuminating Gas. By J. A. WANkiyn and W. J. Cooper. Crown 8vo, 5 s.

Water Analysis: A Treatise on the Examination of Potable Water. By. J. A. WANKLyN and E. T. Chapman. Eighth Edition. Crown 8vo, 5 s.

Fermentation, On. By Professor Schützenberger. With 28 Illustrations. Fourth Edition. Crown $8 v 0,5$ s.

[I. S. S.

Brewing-Chemistry in the Brewing Room: A Course of Lessons to Practical Brewers. By C. H. Piesse. Fcap. 8vo, 5 s.

Pyrology; or, Fire Chemistry. By Lieut.-Col. W. A. Ross. Small 4 to, $36 s$.

Sugar Analysis. For Refineries, Sugar-Houses, Experimental Stations, \&c. By G. Ferdinand Wiechmann. 8vo. ios. 6a'.

Blowpipe Analysis, Alphabetical Manual of. By Licut.-Col. W. A. Ross. Crown 8vo, 5 s.

Practical Blacksmithing. By M. 'T. Richardson. With 400 Illustrations. 4 vols. crown $8 v 0$, 5 s. each. 
Practical Horse-shoer. By M. T. Richardson. With 170 Illustrations. Crown 8vo, 5 s.

Soaps, Manufacture of. By Campbell Morfit. With Illustrations. $8 v o, £ 2,12 s .6 d$.

Pure Fertilisers, and the Chemical Conversion of Rock Guanos, etc., into various valuable products. By CAMpBell Morfit. Svo, £4, 4s.

Photography.-Preparation of Drawings for Photographic Reproduction. By. Col. J. Waterhouse. With Plates. Crown $8 v 0,5$ s.

Mathematics. - Lectures on the Ikosahedron, and the Solution of Equations of the Fifth Degree. By FeLix KLein. Translated by G. G. Morrice. $8 v o$, IOs. $6 d$.

Mathematical Drawing Instruments, and how to use them. By F. Edward Hulme. With Illustrations. Third Edition. Imperial 16mo, 3s. 6 .

Electro-Chemical Analysis. By Edgar F. Smith. With 25 Illustrations. Square 16mo, 5 s.

\section{ART AND MUSIC.}

History of Painting, with Numerous Illustrations. By Alfred Woltmann and Karl Woermann. Medium $8 v o$. Vol. I. Painting in Antiquity and the Middle Ages, 28s. Vol. II. The Painting of the Renascence, $42 s$. The two volumes may be had bound in cloth, with bevelled boards and gilt leaves, price 30 s. and 45 s. respectively.

Discourses. By Sir Joshua Reynolds. Edited by E. Gosse. Elzevir 8vo (Parchment Library). Vellum, 7s. 6d.; parchment or cloth, 6s.

Painting, Lectures on. Delivered to the Students of the Royal Academy. By Edward Armitage. Crown 8vo, 7s. 6 $d$.

Academy Lectures. By J. E. Hodgson. Crown 8vo, 7s. 6d. John Leech: Artist and Humourist. By F. G. KitTon. I $8 m o$, Is.

George Cruikshank, Essay on the Genius of. By W. M. THACKERAY. Reprinted verbatim from the Westminsier Ricvicw. With 40 Illustrations. Koyal 8vo, 7s. 6d. 
Ancient Sculpture, History of. By Lucy M. Mitcheld. With numerous Illustrations. Super-royal 8vo, $42 s$.

Bric-à-Brac : Being some Photoprints illustrating Art Objects at Gower Lodge, Windsor. With Letterpress Descriptions. By LORD RONAld Gower. Super-royal 8vo, I5s.; extra binding, 2Is.

Aesthetics.-The Science of Beauty: An Analytical Inquiry into the Laws of Aesthetics. By A. W. Holmes-Forbes. Second Edition. Post 8vo, 3s. 6d.

Old Masters, A Little Girl among the. By W. D. Howells. With 54 Plates. Oblong crown 8vo, IOS.

Artists of the Nineteenth Century and their Works. By C. E. Clement and L. Hutton. 2050 Biographical Sketches. Third Edition, revised. Crown 8vo, 15 s.

Music, Philosophy of: Lectures delivered at the Royal Institution. By W. Pole. Second Edition. Post 8vo, 7s. 6d. [Phllosophical Llbrary.

T'heory of Sound in its Relation to Music. By Professor P. BLASERna. With numerous Illustrations. Fourth Edition. Crown $8 v 0,5^{\text {s. }}$ [I. S. S.

Music and Action; or, The Elective Affinity between Rhythm and Pitch. By J. Donovan. Crown 8vo, 3s. 6 $d$.

Organ Stops, Explanation of, with Hints for Effective Combinations. By CARL LOCHER. 8vo, 5 s.

Mendelssohn's Letters to Ignaz and Charlotte Moscheles. Translated by F. Moscheles. Numerous Illustrations and Facsimiles. $8 v o, 12 s$.

\section{POETRY AND BELLES-LETTRES.}

Poetical Works of Lewis Morris. New and Cheaper Edition. 5 vols. fcap. $8 v o, 5$ s. each.

Songs of Two worlds. Thirteenth Edition. The Epic of Hades. Twenty-third Edition. Gwen and The Ode of Life. Seventh Edition. Songe Unsung and Gycia. Fifth Edition. Songs of Britain. Third Edition.

Poetical Works. In I vol. crown 8vo, 6s. ; cloth extra, gilt leaves, $75.6 d$. 


\section{Poetical Works of Lewis Morris-Continued.}

The Epic of Hades. With 16 Autotype lllustrations, after the drawings of the late GEORGE R. CHAPMAN. 4to, cloth extra, gilt leaves, $21 s$.

The Eplc of Hades. Presentation Edition. 4to, cloth extra, gilt leaves, IOS. 6 .

The Epic of Hades. Elzevir 8vo, cloth extra, gilt top, 6 s.

Birthday Book. Edited by S. S. Copeman. With Frontispiece. $32 m o$, cloth extra, gilt edges, 2s. ; cloth imp, Is. $6 d$.

A Vision of Saints. Fcap. Svo, 6s.

Poetical Works of Sir Edwin Arnold. Uniform Edition. comprising The Light of Asia, Indian Poetry, Pearls of the Faith, Indian Idylls, The Secret of Death, The Song Celestial, and With Sa'di in the Garden. 8 vols. crown 8vo, $48 s$.

In My Lady's Praise. Poems old and new, written to the honour of Fanny Lady Arnold. Imperial $16 m o$, parchment, 3s. $6 \%$.

Indian Idylls, from the Sanskrit of the Mahâbhârata. Crozen $8 v 0,75.6 d$.

Indian Poetry, containing the Indian Song of Songs from the Sanskrit, two books from the Iliad of India, and other Oriental poems (O. S.). Fifth Edition, 7s. 6d.

Lotus and Jewel. Containing In an Indian Temple, A Casket of Gems, A Queen's Revenge, with other poems. Second Edition. Crown $8 v 0,75.6 \%$.

Pearls of the Faith; or, Islam's Rosary: being the ninety-nine beauti. ful names of Allah. Fourth Edition. Crowun 8vo, 7s. 6i.

Poems, National and Non-Orlental: with some new pieces. Crown Svo, 7s. 6d.

The Light of Asia; or, The Great Renunciation : being the Life and Teaching of Gautama. Presentation Edition. With Illustrations and Portrait. Small 4to, 21s. Library Edition, crown 8vo, 7s. 6d. Elzevir Edition, 6s. Cheap Edition (Lotos Scries), cloth or halfparchment, 3 s. $6 d$.

The Secret of Death: being a version of the Katha Upanishad, from the Sanskrit. Third Edition. Crown Svo, 7s. 6d.

The Song Celestlal; or, Bhagavad-Gitâ, from the Sanskrit. Second Edition. Crown 8vo, 5 s.

With Sa'di in the Garden; or, The Book of Love: being the 'Ishk' or third chapter of the 'Bostân' of the Persian poet Sa'di ; embodied in a dialogue. Crown $8 v 0,75.6 \%$.

The Works of William Shakspere. Avon Lition. I 2 vols. Elawir Svo (Parchment Library). Vellum, 7s. 6ct. per vol. ; Parchment or cloth, 6s. per vol. Cheap Editiun, Is. 6d. per vol.

* * The Cheap Edition may also be had complete, 12 vols. in cloth box, $21 s .$, or bound in 6 vols., 15 s. In one volume, with Glossarial Index, Super royal 8vo, 7s. 6d.

Concordance to Shakespeare's Poems. By MIrs. FuRNEss. I 8 s. 


\section{The Works of William Shakspere-Continued.}

A New Variorum Edition of Shakespeare. Edited by HorACE Howard FuRness. Vol. I. 'Romeo,' Vol. II. 'Macbeth,' Vols. III. and IV. 'Hamlet,' Vol. V. 'Lear,' Vol. vi. 'Othello,' Vol. viI. 'Merchant of Venice,' Vol. VIII. 'As You Like It.' I8s. each vol.

Sonnets. Edited by EDWARD Dowden. With Frontispiece. Elzevir 8vo (Parchment Library). Vellum, 7s. 6d. ; Parchment or cloth, $6 s$.

Index to Shakespeare's Works. By E. O'ConNor. Crowun Svo, 5 s.

Shakespeare Classical Dictionary; or, Mythological Allusions in the Plays of Shakespeare explained. By H. M. Selby. Fcap. 8vo, is.

Shakspere: a Critical Study of his Mind and Art. By EDwarD Dowden. Ninth Edition. Large post 8vo, I2s.

Shakespeare, and other Lectures. By George Dawson. Edited by George St. Clair. Large crown 8vo, 7s. $6 d$.

The Poetical Works of John Milton. 2 vols. Elzevir 8vo. (Parchment Library). Vellum, 7s. 6d. ; Parchment or cloth, 6s.

Sonnets. Edited by MARK PATtison. With Portrait. Elzevir 8vo (Parchment Library). Vellum, 7s. 6d. ; Parchment or cloth, 6s.

Chaucer's Canterbury Tales. Edited by A. W. Pollard. 2 vols. Elzevir $8 v 0$ (Parchment Library). Vellum, I5s.; Parchmient or cloth, $12 \mathrm{~s}$.

Canterbury Chimes; or, Chaucer Tales retold to Children. By F. STORR and H. TURner. With 6 Illustrations from the Ellesmere Manuscript. Third Edition. Fcap. 8vo, 3s. 6d.

Poems of P. B. Shelley. Edited by Richard Garnett. With Frontispiece. Elzevir $8 v o$ (Parchment Library). Vellum, 7s. 6d. ; Parchment or cloth, 6s.

The Poetical Works of John Keats. Edited by W.T. ARNOLD. Large crozun 8vo. Choicely printed on hand-made paper. With Etched Portrait. Vellum, I 5s.; Parchment or cloth, I2s. New Edition. Crown Svo, cloth, 3s. 6d.

Selected Poems of Matthew Prior. Edited by Austin DOBSON. Elzevir 8vo (Parchment Library.) Vellum, 7s. 6d.; Parchment or cloth, 6s.

Fables of John Gay. Edited by Austin Dobson. With Portrait. Elzevir $8 v 0$ (Parchment Library). Vellum, 75. 6d. Parchment or cloth, 6s.

Selections from Wordsworth. By William Knight and other Members of the Wordsworth Society. Printed on hand-made paper. Large crown 8vo. With Portrait. Vellum, I5s.; Parchment, I2s. Cheap Edition. Crown 8vo, 4s. 6d.

Wordsworth Birthday Book. Edited by ADELAIDE and VIOLET WORDSWORTH. 32mo, 2s. ; cloth limp, Is. $6 d$. 
Works of Sir Henry Taylor. 5 vols. crozen 8vo, 30 s.

Philip van Artevelde. Fcap. 8vo, 3s. $6 d$.

The Virgin Widow, etc. Fcap. Svo, 3s. 6d.

The Poems of Ebenezer Elliott. Edited by his son, the Rev. Edwin ElifotT, of St. John's, Antigua. 2 vols. crown 8vo, I8s.

Poems by W. Cullen Bryant. Cheap Edition. Small 8vo, 3s. 6d.

Poems of Edgar Allan Poe. Edited by AndRew LANG.

With Frontispiece. Elzevir 8vo (Parchment Library). Vellum, 7s. 6d.; Parchment or cloth, 6s.

The Raven: with Commentary by John H. Ingram. Crowen 8vo, parchment, $6 s$.

Poems by Archbishop Trench. Tenth Edition. Fcap. 8vo, 7s. 6d. Library Edition. 2 vols. small 8vo, Ios.

Sacred Latin Poetry, chiefly Lyrical. By Archbishop Trench. Third Edition. Corrected and Improved. Fcap. 8vo, 7s.

Household Book of English Poetry. Edited by ARCHBISHOP TRENCH. Fourth Edition, revised. Extra fcap. 8vo, 5 s.

English Verse. Edited by W. J. Linton and R. H. Stoddard. 5 vols. crown 8vo, 5 s. each.

Chaucer to Burns. Translations. Lyrics of the Nineteenth Century. Dramatic Scenes and Characters. Ballads and Romances.

Rare Poems of the Sixteenth and Seventeenth Centuries. Edited by W. J. Linton. Crown 8vo, 5 s.

English Lyrics. Elzevir 8vo (Parchment Library). Vellum, 7s. 6d.; Parchment or cloth, 6s.

English Sacred Lyrics. Elzevir 8vo (Parchment Library). Vellum, 7s. 6d. ; Parchment or cloth, 6s.

Selected Poems of Robert Burns. With an Introduction by Andrew Lang. Elzevir 8vo, vellum, 7s. 6d.; Parchment or cloth, 6s. (Parchment Library).

Lucile. By the late EARL of LytTon. With 32 Illustrations. $16 \mathrm{mo}, 4 s .6 d$.

Rhymes from the Russian. By John Pollen. Translations from the best Russian Poets. Crown 8vo, 3s. $6 d$.

English Odes. Edited by E. Gosse. With Frontispiece. Elzevir Svo (Parchment Library). Vellum, 7s. 6d.; Parchment or cloth, 6 s.

Living English Poets. With Frontispiece. By WaLter Crane. Second Edition. Large crown Sro, printed on hand-made paper, vellum, I5s.; cloth, I2s. 
Sea Song and River Rhyme, from Chaucer to Tennyson. With Twelve Etchings. Edited by Estelle ADams. Large crown $8 v 0$, ios. $6 d$.

Breitmann Ballads. By C. G. Leland. Only Complete Edition, including I9 Original Ballads, illustrating his travels in Europe. Crown 8vo, 6s. Another Edition (Lotos Series), 3s. 6a.

Gaudeamus: Humorous Poems from the German of Joseph Victor Scheffel and others. Translated by C. G. Leland. $16 m o, 3 s .6 d$.

Pidgin-English Sing-Song; or, Songs and Stories in the China-English dialect. Second Edition. By C. G. Leirand. Crown $8 v 0,5$ s.

Ballades in Blue China. By Andrew Lang. Elzevir 8vo, 5 s. Rhymes à La Mode. By Andrew Lang. With Frontispiece By E. A. Abbey. Second Edition. Elzevir 8vo, 5 s.

Poems of Rural Life in the Dorset Dialect. By William Barnes. New Edition. Crown 8vo, 6s.

old World Idylls, and Other Verses. By Austin Dobson. Elzevir 8vo, gilt top, 6 s.

At the Sign of the Lyre. By Austin Dobson. Elzevir $8 v 0$, gilt top, $6 s$.

Birds and Babies. By Ethel Coxhead. With 33 Illustrations. Second Eidition. Imperial $16 m o$, cloth gilt, 2s. $6 d$.

The Christian Year. By J. Keble. With Portrait. Elzevir 8vo (Parchment Library). Vellum, 7s.6d.; Parchment or cloth, 6s.

The Poems of Wilfrid Scawen Blunt.

The wind and the Whirlwind. 8vo, is. $6 d$.

The Love Sonnets of Proteus. Fifth Edition. Elzevir 8vo, 5 s.

In Vinculis. With Portrait. Elzevir 8vo, $5^{s}$.

A New Pilgrimage; and other Poems. Elzevir 8vo, 5 s.

Book of Chinese Poetry. By C. F. Romilly Allen. Being the collection of Ballads, Sagas, Hymns, and other Pieces known as the Shih Ching, metrically translated. 8vo, I6s.

Shadows of the Lake, and other Poems. By F. Leyton. Second Edition. Crown 8vo, 5 s.

The Poems of Mrs. Hamilton King. The Disciples. Tenth Edition. Elzevir 8vo, 6s.; Small 8vo, 5 s.

A Book of Dreams. Third Edition. Crown 8vo, 3s. 6d.

Sermon in the Hospital (from 'The Disciples'). Fcap. 8vo, Is. Cheap Edition, 3d.

Ballads of the North; and other Poems. Crown 8vo, $5 \mathrm{s.}$ 
A Lover's Litanies, and other Poems. With Portrait of Author. By Eric Mackay. (Lotos Series), 3s. 6d.

Goethe's Faust. Translated from the German by JoHN ANSTER. With an Introduction by BURDETT MASON. With Illustrations (I8 in Black and White, Io in Colour), by FrANK M. Gregory. Grand folio, £3, 3 s.

French Lyrics. Edited by George SaIn'tsbury. With Frontispiece. Elzevir Svo (Parchment Library). Vellım, 7s. 6d.; Parchment or cloth, $6 s$.

Poems by Alfred Gurney. The Vision of the Eucharist, and other Poems. Crown 8vo, 5 s.

A Christmas Faggot. Small 8vo, 5 s.

Voices from the Holy Sepulchre, and other Poems. Crown 8vo, 5 s.

Poems by Edmund Gosse. New Poems. Crozen 8vo, 7s. 6d.

Firdausi in Exile, and other Poems. Second Edition. Elzevir 8ro, gilt top, $6 s$.

On Viol and Flute: Lyrical Poems. With Frontispiece by L. ALMA TADEMa, and Tailpiece by Hamo ThORNYCROFT. Elzevir 8vo, $6 s$.

London Lyrics. By F. Locker. Tenth Edition. With Portrait. Elzevir Svo, cloth extra, gilt top, 5 s.

English Comic Dramatists. Edited by Oswald Crawfurd. Elzevir 8vo (Parchment Library). Vellum, 7s. 6d.; Parchment or cloth, $6 s$.

Poems by Toru Dutt. A Sheaf gleaned in French Fields. Svo, IOs. 6\%.

Ancient Ballads and Legends of Hindustan. With an Introductory Memoir by EDMund Gosse. I $8 m o$, cloth extra, gilt top, 5 s.

St. Augustine's Holiday, and other Poems. By William Alexander, D.D., Bishop of Derry. Crozon Szo, 6s.

A Strange Tale of a Scarabæus, and other Poems. By A. C. P. Haggakd. Crown 8vo, 3s. 6\%.

A Song-Book of the Soul. By Marjory G. J. Kinloch. Crown 8ro, 5 s.

Lyrics and Other Poems. By Lady Lindsay. Second Edition, Elzevir Svo, 5 s.

Psalms of the West. Small 8vo, is. 6d.

Louise de la Vallière, and other Poems. By Katherine Trisan. Small Svo, 3s. 6r. 
Shamrocks. By Katherine Tynan. Small 8vo, 5 s.

Ballads and Lyrics. By Katherine Tynan. Small Svo, 5 s.

Granite Dust. Fifty Poems. By Ronald Campbell Macfie. Crowen 8zo, 2s. 6d.

Carmela; or, The Plague of Naples. Crozen 8vo, 2s. $6 d$.

The Marriage of the Soul, and other Poems. By W. ScotTElliot. Crown 8vo, 5 s.

Beauty and the Beast; or, A Rough Outside with a Gentle Heart. A Poem. By Charles lamb. Fcap. 8vo, vellum, ios. $6 d$.

In Hours of Leisure. By Clifford Harrison. Second Edition. Crown 8vo, 5 s.

Verses Written in India. By Sir Alfred Lyall. Elzevir $8 v o$, gilt top, 5 s.

Analysis of Tennyson's 'In Memoriam.' (Dedicated by permission to the Poet Laureate.) By F. W. Rober'Tson. Fcap. 8vo, 2s.

India Revisited. By SIR Edwin ARNold. With 32 Full page Illustrations. Crown 8vo, 7s. 6d.

Milton's Prose Writings. Edited by E. Myers. Elzevir 8vo (Parchment Library). Vellum, 7s. 6d.; Parchment or cloth, 6s.

Select Letters of Shelley. Edited by Richard GarnetT. Elzevir 8vo (Parchment Library). Vellum, 7s. 6d.; Parchment or cloth, $6 s$.

Calderon.-Essay on the Life and Genius of Calderon. With translations from his 'Life's a Dream' and 'Great Theatre of the World.' By Archbishop Trench. Second Edition, revised and improved. Extra fcap. 8vo, 5s. 6d.

Confessions of an English Opium Eater. By DE Quincey. Edited by Richard GarnetT. Elzevir $8 v o$ (Parchment Library). Vellum, 7s. 6d. ; Parchment or cloth, 6s.

A Word for the Navy. By Algernon Charles Swinburne. (Only 250 Copies printed.) Imperial 16 mo, paper covers, 5 s.

Biglow Papers. By James Russell Lowell. Edited by Thomas Hughes, Q.C. Fcap. 8vo, 2s. $6 d$.

Robert Browning. - Studies in the Poetry of Robert Browning. By James Fotheringham. Second Edition. Crown 8vo, $6 s$.

Lost Leaders. By Andrew Lang. Crozen 8vo, 5 s. 
Goldsmith's Vicar of Wakefield. Edited by Austin DoBSON. Elzevir Svo (Parchment Library). Vellum, 7s. 6d.; Parch. ment or cloth, 6 s.

Eighteenth Century Essays. Edited by Austin Dobson. With Frontispiece. Elzevir 8vo (Parchment Library). Vellum, 7s. 6il.; Parchment or cloth, 6s. Cheap Edition. Fcap. 8vo, Is. 6d.

Four Centuries of English Letters: A Selection of $35^{\circ}$ Letters by 150 Writers, from the period of the Paston Letters to the present time. Edited by W. B. Scoones. Third Edition. Large crown 8vo, 6s.

Munchausen's Travels and Surprising Adventures. Illustrated by Alfred Crowquill. (Lotos Series), 3s. $6 d$.

Specimens of English Prose Style from Malory to Macaulay, Selected and Annotated. With an Introductory Essay by GEORGE SAINTSBURY. Large crown 8vo, printed on hand-made paper, vellum, I5s.; Parchment antique or cloth, I2s.

Macaulay's Essays on Men and Books : Lord Clive, Milton, Earl of Chatham, Lord Byron. Edited by Alex. H. JAPP (Lotos Series), 3s. $6 d$.

The Countess of Pembroke's Arcadia. By SiR PhiliP Sinney, Kt. Edited by H. Oskar Sommer. The original 4 to Edition (1590) in Photographic Facsimile, with Bibliographical Introduction.

Carlyle's Sartor Resartus. Elzevir 8vo (Parchment Library). Vellum, 7s. 6d. ; Parchment or cloth, 6s.

Swift's Letters and Journals. Edited by Stanley Lane Poole. Elzevir Svo (Parchment Library). Vellum, 7s. 6d.; Parchment or cloth, 6s.

Swift's Prose Writings. Edited by Stanley Lane Poole. With Portrait. Elzevir Svo (Parchment Library). Vellum, 7s. 6\%.; Parchment or cloth, 6s.

Vagabunduli Libellus. By John Addington Symonds. Crown 8vo, 6s.

Disraeli and His Day. By Sir William Fraser, Bart. Second Edition. Post Sro, 9s.

\section{NOVELS AND WORKS OF FICTION.}

Novels By George MacDonald.

Donal Grant. With Frontispiece. Crown 8vo, 6s. Cheap Edition, 35. $6 \%$

Home Again. With Frontispiece. Crown 8vo, 6s.

Castle warlock. With Frontispicce. Crowen 8vo, 6s. Cheap Edition, 3s. 6 . 


\section{Novels by George Macdonald-Continued.}

Malcolm. With Portrait of the Author engraved on Steel. Crozen 8vo, 6s. Cheap Edition, 3s. 6d.

The Marquis of Lossie. With Frontispiece. Crown 8vo, 6s. Cheap Edition, 3s. 6 d.

st. George and St. Michael. With Frontispiece. Cromen 8vo, 6 s.

What's Mine's Mine. With Frontispiece. Crowen 8vo, 6s. Cheap Edition, 3s. $6 d$.

Annals of a Quiet Neighbourhood. With Frontispiece. Crown 8vo, 6 s. The Seaboard Parish : a Sequel to 'Annals of a Quiet Neighbourhood.' With Frontispiece. Crozun Svo, 6s.

Wilfrid Cumbermede : an Autobiographical Story. With Frontis. piece. Crown Svo, 6s.

Thomas Wingfold, Curate. With Frontispiece. Crown 8vo, 6s.

Paul Faber, Surgeon. With Frontispiece. Crown Svo, 6s.

The Elect Lady. With Frontispiece. Crown $8 v o, 6 s$.

There and Back. With Frontispiece. Crosun 8vo, 6s.

Flight of the Shadow. With Frontispiece. Crown 8vo, 6s.

Hawthorne's Novels and Tales. - Works. By NATHANiEI. Hawthorne. Complete in 12 vols. Large post 8vo, 7s. 6\%. each.

Novels by Col. Meadows Taylor.

Seeta: A Novel. With Frontispiece. Crown 8vo, 6s.

Tippoo sultaun: A Tale of the Mysore War. With Frontispiece. Crozen 8vo, 6s.

Ralph Darnell. With Frontispiece. Crown 8vo, 6s.

A Noble Queen. With Frontispiece. Crown Svo, 6 s.

The Confessions of a Thug. With Frontispiece. Crown 8vo, 6s.

Tara: A Mahratta Tale. With Frontispiece. Crozun 8vo, $6 \mathrm{~s}$.

\section{Novels by Hesba Stretton.}

David Lloyd's Last Will. With 4 Illustrations. New Edition, R'oyal i $6 \mathrm{mo}, 2 s$. $6 d$.

Through a Needle's Eye: A Story. With Frontispiece. Crown 8vo, 6s.

\section{Novels by Maxwell Gray.}

In the Heart of the Storm. With Frontispiece. Crown 8vo, 6s.

The Reproach of Annesley. With Frontispiece. Crozun 8vo, 6s.

Silence of Dean Maitland. With Frontispiece. Crozen 8vo, $6 \mathrm{~s}$.

Novels by Rowland Grey.

In Sunny Switzerland; A Tale of Six Weeks. Second Edition. Small Svo, 5s.

Lindenblumen, and other Stories. Small 8vo, 5 s.

By Virtue of His Office. Croun 8vo, 6 s.

Jacob's Letter, and other Stories. Croum Svo, 6s. 


\section{Novels by 'Tasma.'}

A Sydney Sovereign, and other Tales. Crown 8vo, cloth, 6s.

In Her Earliest Youth. Cheap Edition. Croiun 8vo, 6 s.

Novels by Lucas Malet.

Colonel Enderby's Wife. With Frontispiece. Crown 8vo, 6s.

A Counsel of Perfection. With Frontispiece. Crown 8vo, 6s.

Little Peter : a Christmas Morality for Children of any age. With numerous Illustrations. Fourth Thousand. 5 s.

Stories by Mrs. G. S. Reaney.

Waking and Working; or, From Girlhood to Womanhood. Nere and Cheafer Edition. With Frontispiece. Crown 8vo, 3s. $6 d$.

Blessing and Blessed : a Sketch of Girl Life. Nerw and cheaper Edition. Crown Svo, 3s. $6 d$.

Rose Gurney's Discovery: a Story for Girls. Dedicated to their Mothers. Crown Svo, 7s. 6d.

English Girls: Their Place and Power. With Preface by the Rev. R. W. Dale. Fifth Edition. Ficap. 8vo, 2s. $6 d$.

Just Any One, and other Stories. With 3 Illustrations. I6mo, Is. $6 d$.

Sunbeam Willie, and other Stories. With 3 Illustrations. I6mo, $1 s .6 d$.

Sunshine Jenny, and other Stories. With 3 Illustrations. I6mo, Is. $6 d$.

The Prig.-Black is White; or, Continuity Continued. 3 s. $6 d$. The Prigment: 'The Life of a Prig,' 'Prig's Bede,' 'How to make a Saint,' 'Mlack is White.' Second Edition. In I vol. crown Svo, 5 s.

A Romance of the Recusants. Crown 8vo, 5 s.

Sultan Stork, and other Stories and Sketches, 1829-44. By W. M. Thackeray. Now first collected, to which is added the Bibliography of Thackeray. Large $8 v 0$, IOs. $6 d$.

In the Wrong Paradise, and other Stories. By AndREw LaNG. Crown 8vo, 6s.

Riches or Ruin. A Story. By the Author of 'The Prigment.' Crown 8io, 3s. 6d.

Egosophy. By the Author of 'The Prigment.' Crozen $8 v 0,3$ s. $6 d$.

Strange True Stories of Louisiana.. By G. W. Cable. 8vo, 7 s. $6 d$.

South Africa. An I. D. B. in South Africa. By Louise Viscelius-SHeldon. Illustrated. Crown 8vo, 7s. $6 d$.

Zululand.-Yankee Girls in Zululand. By Louise Vescelius-SHeldon. Illustrated. Crown $8 v 0,5$ s. 
Tyll Owlglass' Marvellous and Rare Conceits. Translated by Kenneth Mackenzie. Illustrated by Alfred Crowquil.. (Lotos Series), 3s. 6d.

The Fortunate Lovers: Twenty-seven Novels of the QueEN of Navarre. Edited by A. Mary F. Robinson. Frontispiece by G. P. JAсомв Hood. Large crozen $8 v o$, Ios. $6 d$.

A Professor of Alchemy. By Percy Ross. Crozen 8vo, 3s. $6 d$. The Wing of Azrael. By Mona Caird. Crown 8vo, $6 \mathrm{~s}$.

Off the Skelligs : A Novel. By Jean Ingelow. With Frontispiece. Crown 8vo, 6 s.

My Ducats and My Daughter. By Hay Hunter and Walter Whyte. With Frontispiece. Crown 8vo, 6s.

Plucky Fellows: A Book for Boys. By S. T. Mackenna. With 6 Illustrations. Fifth Edition. Crown 8vo, 3 s. $6 d$.

Mosquito: A Tale of the Mexican Frontier. By Frances Francis, Crown 8vo, 3 s. $6 d$.

The Pillar House. By Florence Severne. With Frontispiece. Crozen 8vo, 6s.

Sylvia Arden. By Oswald Crawfurd. With Frontispiece. Crown Svo, is.

Within Sound of the Sea. With Frontispiece. Crozen 8vo, $6 s$. Castle Blair: A Story of Youthful Days. By Flora L. SHaw. Crowen 8vo, 3s. 6d.

The Apothecary's Daughters. Translated from the Danish of Henrik Pontopiddan, by Gordius Niel.sen. Crown 8vo, 3s. $6 d$. Scot Free: $\Lambda$ Novel. By C. G. Compton. Crozen 8vo, $6 s$.

Christy's Inheritance: A London Story. By Florence Whitaker. Illustrated. Royal I6mo, is. 6d.

A Lost Love. By Anna C. Ogle. Small crozen 8vo, 2s. $6 d$. Through To-day. A Novel. Crozen óvo, 5 s.

The Story of a Friendship. By the Rev. Alfred Gurney. Crown 8vo, 5 s.

His Heritage. By Linda Gardiner. With Frontispiece. Crown 8vo, 6s.

Novels by Rosa Mulholland.

Marcella Grace: an Irish Novel. Crown 8vo, 6s.

A Falr Emigrant. With Frontispiece. Crown 8vo, 6s. 
A Sensitive Plant: A Novel. By E. and D. Gerard. Crown Svo, 6s.

Ulli: The Story of a Neglected Girl. Translated from the German of Emma Biller, by A. B. Daisy Rost. Crown 8vo, $6 s$.

God's Providence House. By Mrs. G. Linneus Banks. Crowen 8vo, 6s.

At Sundry Times and in Divers Manners. By MaY Eleanor BeNson. With Portrait and Memoir. 2 vols. Crown 8vo, IOs. $6 d$.

\section{BIBLIOGRAPHY.}

Periodical Literature, Index to. By W. F. Poole. Third Edition. Royal 8vo, £3, I3s. $6 d$.

Periodical Literature, Index to. First Supplement. By W.

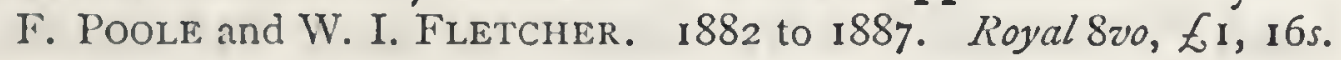

American Literature, Trübner's Bibliographical Guide to. From ISI7 to 1887. 8vo, half-bound, I8s.

Dictionaries and Grammars, Truibner's Catalogue of Dictionaries and Grammars of the Principal Languages and Dialects of the World. Second Edition. 8vo, 5 s.

Memoirs of Libraries, together with a Practical Handbook of Library Economy. By EDward EDwards. Numerous Illustrations. 2 vols. Rioyal 8vo, £2, 8s.

Libraries and Founders of Libraries. By EDWARD EDWARDS. $8 v o$, I $8 s$.

Free Town Libraries: Their Formation, Management, and History, with brief notices of Book Collectors. By EDWARD EDWARDS. 8vo, 2 Is.

Philobiblon. By Richard De Bury. Edited by E. C. Thomas. Crown 8vo, Ios. $6 d$.

Egypt and the Soudan, The Literature of: A Bibliography, comprising Printed Books, Periodical Writings, and Papers of Learned Societies. Maps and Charts, Ancient Papyri Manuscripts, Drawings, etc. By H. H. Prince Ibrahim Hilmy, 2 vols. demy 4 to, £3, $3^{s}$.

Bibliography of Alchemy.-Lives of Alchemystical Philosophers. With a Bibliography of Alchemy. By A. E. WaITE. $8 v 0$, 10s. 6 \%

Browning.-Bibliography of Robert Browning from 1833 to I 89 I. I2s. 
Swinburne.-Bibliography of Algernon Charles Swinburne from IS57 to I887. Crown Svo, vellum, silt, 6 s.

The Countess of Pembroke's Arcadia. Written by Sir PHiLiP Sidney, Knt. The original Quarto Edition (I590), in Photographic Facsimile, with Bibliographical Introduction. Edited by H. Oskar SOMMER.

Thackeray, Bibliography of. Sultan Stork, and other Stories and Sketches, I829-44, now first collected. To which is added the Bibliography of Thackeray. Large Svo, IOs. $6 d$.

Antiquarian Magazine and Bibliographer, The. Edited by EDward Walford and G. W. Redway. Complete in. I 2 vols. Svo, £3 net.

British Museum Publications. List on application.

\section{GASTRONOMY AND DIET, CHESS MANUALS, AND MISCELLANEOUS WORKS.}

Foods. By E. Smiтh. With numerous Illustrations. Nint/ Edition. Crown 8vo, 5 s.

[I. S. S.

Curry Cook's Assistant. By Daniel Santiagoe. Fcap. Svo, Is. 6d.; Paper covers, is.

Wholesome Cookery. By Madame Marie de Joncourt. Fifth Edition. Crown 8vo, Is. 6d.; Paper covers, Is.

Soups and Stews, and Choice Ragouts. By Miss Cameron. Is. 6d.; Paper covers, Is.

Luncheon Dishes ; Comprising Menus in French and English, as well as Suggestions for Arrangement and Decoration of Table. By Mary L. Allen. Fcap. 8vo, cloth, is. 6d.; paper, is.

Five 0'clock Tea: Containing Receipts for Cakes, Savoury Sandwiches, etc. Eighth Thousand. Fcap. 8vo, Is. 6d; Paper covers, Is.

Luncheon Dishes ; comprising Menus in French and English, as well as Suggestions for Arrangement and Decoration of Table. By Mary L. AlLEN. Fcap. 8vo, sloth, Is. 6d.; paper covers, Is.

Little Dinners: How to Serve them with Elegance and Economy. By Mary Hooper. Tiventy-first Edition. Crown 8vo, $2 s .6 d$.

Cookery for Invalids, Persons of Delicate Digestion, and Children. By Mary HOOPER. Fifth Edition. Crown 8vo, 2s. 6d 
Every-Day Meals : Being Economical and Wholesome Kecipes for Breakfast, Luncheon, and Supper. By MARY HoOper. Seventh Edition. Crown Svo, 2s. 6d.

Essays on Diet. By Francis William Newman. Small Svo, cloth limp, 2 s.

Diet in Relation to Age and Activity. By Sir H. Thompson. Fcap. 8vo, is. 6d.; Paper covers, is.

Perfect Way in Diet, The: A Treatise advocating a return to the Natural and Ancient Food of our race. By ANNA KingsFord. Third Edition. Small Svo, 2 s.

Rowing at Westminster, $1813-83$ : Extracted from the School Water Ledgers. Crown 8vo, 5 s.

Elocution, Lectures on, Delivered at King's College. By C. J. Plumptre. Fourth Edition. Post 8vo, 15 s.

Chess-Player's Text Book, The: An Elementary Treatise on the Game of Chess. By G. H. D. Gossip. Numerous Diagrams. $16 m o, 2 s$.

Chess Openings, Ancient and Modern. Revised and Corrected up to the Present Time from the best Authorities. By E. Freeborough and C. E. Ranken. Large Post 8vo, 7s. $6 d$.

Chess Endings: A Companion to Chess Openings, Ancient and Modern. Edited and arranged by E. Freeborough. Large post $8 v 0,7 s .6 d$.

Chess Exemplified in One Hundred and Thirty-two Games of the Most Celebrated Players. By W. J. Greenwei.l. 8vo, 5 s.

Angling Resorts near London: The Thames and the Lea. By J. P. Whendon. Crown 8vo, Paper, is. $6 d$.

Practical Heraldry: An Epitome of English Armoury. By Charles Worthy. With I24 Illustrations. Crown $8 v 0,75.6 d$.

Heraldry, English and Foreign. By R. C. Jenkins. With a Dictionary of Heraldic Terms and 156 Illustrations. Small 8vo, 3 s. $6 d$.

Practical Mercantile Correspondence: A Collection of Modern Letters of Business. With Notes. By William Anderson. Thirtieth Edition, Revised. Crown 8vo, 3s. 6 .

Mercantile Correspondence: A Collection of Letters in Portuguese and English, treating of the system of business in the principal cities of the world. By W. ANDERSON and J. E. TUGMAN. $12 m o, 6 s$.

Wells Wills, Arranged in Parishes and Annotated. By F. W. Weaver. Svo, ios. $6 d$. 
Goidelica: Old and Early-Middle Irish Glosses, Prose and Verse. By Whitley Stokes. Second Edition. Medium $8 v 0$, I 8 s.

Slavery.-Anglo-Saxon Abolition of Negro Slavery. By Francis William Newman. 8vo, 5 s.

Modern Cremation. By Sir H. Thompson. Second Edition, lievised and Enlarged. Crown 8vo, Is.; cloth, 2s.

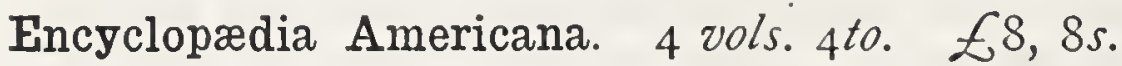

Rig Veda Americanus. By D. G. Brinton. 8vo, i $2 s$.

Essays of an Americanist. By D. G. Brinton. 8vo, izs.

Days with Industrials: Adventures and Experiences among Curious Industries. By AleXANDER H. JAPP. With Illustrations. Crown 8vo, 6s.

Our Railways: Sketches, Historical and Descriptive, with information as to Fares and Rates, etc. By Joseph Parslow. Crown 8vo, 6s.

In Praise of Ale : Songs, Ballads, Epigrams, and Anecdotes. By W. T. Marchant. Crozm 8vo, IOs. $6 d$.

In Cap and Gown: 'Three Centuries of Cambridge Wit. By Charles Whibley. Second Edition. Crown 8vo, 7s. $6 d$.

Dance of Death, The, in Painting and in Print. By T. TyNDAll Wildridge. With Woodcuts. Small 4to, 3s. 6d.

Cattle Ships: Being the Fifth Chapter of 'An Appeal for our Seamen.' By Samuel Plimsoll. With 46 Illustrations. 5s.; Cheap Edition, Is.

My Friends at Sant 'Ampelio. By J. A Goodchuld. Crozen $8 v 0,7 s .6 d$.

Myth and Science: An Essay. By Tito Vignoli. Third Edition. With Supplementary Note. Crown 8vo, 5s. [I. S. S.

Miscellaneous Essays. By H. T. Colebrooke, with Biography by his Son, Sir T. E. Colebrooke. 3 vols. 8vo, $42 s$.

Shut Your Mouth and Save Your Life. By George Catlin With 29 Illustrations. Eighth Edition. Crown 8vo, 2s. 6 d.

The Inspection of Meat: A Guide and Instruction Book to Officers supervising Contract Meat, and to all Sanitary Inspectors. With 32 Coloured Plates. Br W. WyLdE. 8vo, IOs. $6 d$. 
Count Tolstoi ; as Novelist and Thinker: Lectures delivered at the Royal Institution. By C. E. Turner. Crown 8vo, 3s. 6d.

Modern Novelists of Russia: Lectures delivered at the Taylor Institution, Oxford. By C. E. TURner. Crown 8vo, 3s. 6d.

Characteristics from the Writings of Cardinal Newman. Selections from his various Works. Arranged by W. S. Lilly. Eighth Edition. With Portrait. Crown 8vo, 6s.

* * Portrait of the late Cardinal Newman, mounted for framing, 2s. $6 d$.

A Century of American Literature. Benjamin Franklin to James Russell Lowell. By Huntington Smith. Crown Svo, 6s.

Comparative Literature. By H. M. Posnetr. Crown 8vo, 5 .

[I. S. S.

Studies in Literature, 1789-1877. By Edward DOWden. Fourth Edition. Large post 8vo, 6s.

Transcripts and Studies. By Edward Dowden. Large post $8 v 0$, I 2 s.

Seventeenth Century Studies: A Contribution to the History of English Poetry. By Edmund Gcsse, 8vo, Ios. $6 d^{\circ}$.

Literary and Social Judgments. By W. R. GREG. Fourth Edition. 2 vols. crowen Svo, I 5 s.

Winding Way, The. By J. S. Fletcher. Crown 8vo, $6 s$.

Life's Greatest Possibility. An Essay in Spiritual Realism. Ficap. 8vo, 2s. 6d.

Gardencraft, Old and New. By John 1). Sedding. With Memorial Notice by the Rev. E. F. Russeld. 16 Illustrations. Svo, I2s.

Messrs. KEGAN PAUL, TRENCH, TRÜBNER \& CO., Ltd., are also Publishers to the following Societies, etc., lists of publications of which may be had on application :-

The Browning Society.

The Chaucer Society.

The English Dialect Society.

The Early English Text Society.

The Royal Soclety.
The New Suakspere Society.

The Wagner Society.

The British Museum.

The Geological Survey of India.

The India Office. 


\section{PERIODICALS.}

Anthropological Institute of Great Britain and Ireland, Journai of. Quarterly. 5 s.

Asiatic Society of Bengal, Journal of. $8 v o$ 3s. per numler. Proceedings, Is. per umber.

Asiatic Society, Royal. Bombay Branch. Journal.-Irregular. Asiatic Society, Royal. Ceylon Branch. Journal.-Irregular. Asiatic Society, Royal. China Branch. Journal.-Irregular. Asiatic Society, Royal. Straits Branch. Journal.-Irregular. Bibliotheca Sacra. Quarterly, 3s. 6d. Annual Subscription, I $4 s$. British Chess Magazine. Monthly, $9 d$.

Calcutta Review. Quarterly, 6s.

Geological Magazine, or Monthly Journal of Geology, is. $6 d$. Annual Subscription, i8s.

Index Medicus. A Monthly Classified Record of the Current Medical Literature of the World. Annual Subscription, 50s. Indian Antiquary. A Journal of Oriental Research in Archæology, History, Literature, Languages, Philosophy, Religion, Folklore, etc.

Indian Evangelical Review. Annual Subscription, £2.

Orientalist, The. Monthly.

IOS.

Meister, The. Journal of the Wagner Society. Irregular. $6 s$. Orthodox Catholic Review. Irregular.

Philological Society, Transactions and Proceedings of. Irregular.

Psychical Research Society, Proceedings. Irregular.

Sanitarian. Devoted to the Preservation of Health, Mental and Physical Culture. Monthly.

Science. Weekly.

Scientific American. Weekly. Annual Subscription, i8s. - Export Edition. Monthly. " Building Edition. Monthly. " I 4 . Supplement. Weekly.

Tropical Agriculturist. Monthly. $" \quad £ \mathrm{r}, 5 s$.
$\quad \ldots \mathrm{r}, 6 s$. Parents' Review. Monthly. 6d. Sun Artists. Quarterly. 5 s. 


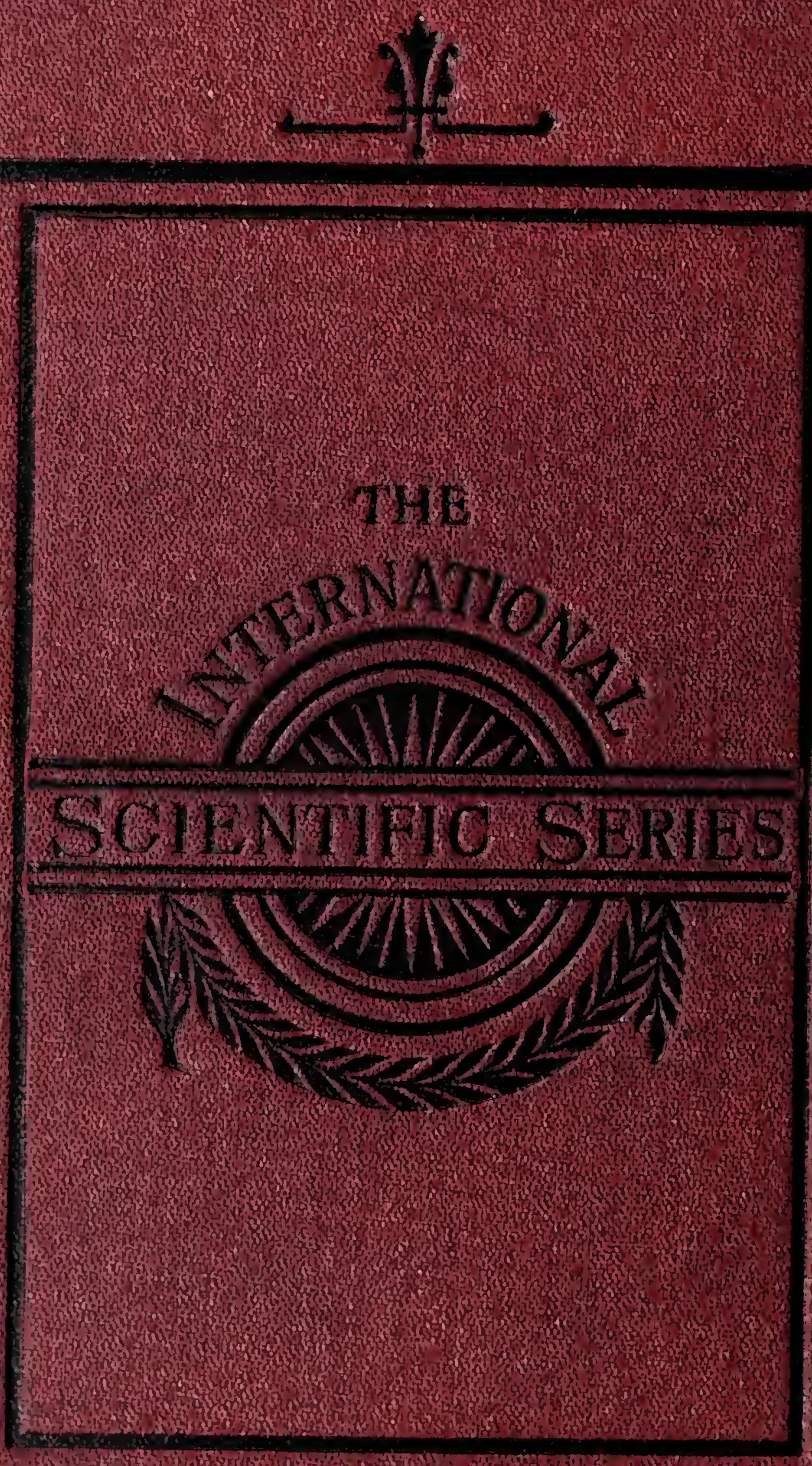